IMPACT OF EMPIRE - VOLUME 2 I

\title{
ROME AND \\ THE WORLDS \\ BEYOND ITS \\ FRONTIERS
}

Edited by

Daniëlle Slootjes and Michael Peachin

B R I L L 
Rome and the Worlds Beyond Its Frontiers 


\title{
Impact of Empire
}

ROMAN EMPIRE, C. 200 B.C.-A.D. 476

\author{
Edited by \\ Olivier Hekster \\ (Radboud University, Nijmegen, The Netherlands)
}

\author{
Editorial Board \\ Lukas de Blois \\ Angelos Chaniotis \\ Ségolène Demougin \\ Olivier Hekster \\ Gerda de Kleijn \\ Luuk de Ligt \\ Elio Lo Cascio \\ Michael Peachin \\ John Rich \\ Christian Witschel
}

VOLUME 21

The titles published in this series are listed at brill.com/imem 


\title{
Rome and the Worlds Beyond Its Frontiers
}

\author{
Edited by \\ Daniëlle Slootjes and Michael Peachin
}

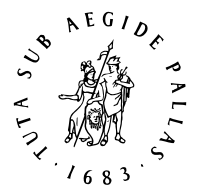

B R I L L 


\section{\begin{tabular}{|l|}
\hline B R I L L \\
\hline P E N
\end{tabular}}

This is an open access title distributed under the terms of the CC-BY-NC 4.0 License, which permits any non-commercial use, distribution, and reproduction in any medium, provided the original author(s) and source are credited.

The Library of Congress Cataloging-in-Publication Data is available online at http://catalog.loc.gov LC record available at http://lccn.loc.gov/2016036673

Typeface for the Latin, Greek, and Cyrillic scripts: “Brill”. See and download: brill.com/brill-typeface.

\section{ISSN 1572-0500}

ISBN 978-90-04-32561-6 (hardback)

ISBN 978-90-04-32675-0 (e-book)

Copyright 2016 by Koninklijke Brill NV, Leiden, The Netherlands.

Koninklijke Brill NV incorporates the imprints Brill, Brill Hes \& De Graaf, Brill Nijhoff, Brill Rodopi and Hotei Publishing.

All rights reserved. No part of this publication may be reproduced, translated, stored in a retrieval system, or transmitted in any form or by any means, electronic, mechanical, photocopying, recording or otherwise, without prior written permission from the publisher.

Authorization to photocopy items for internal or personal use is granted by Koninklijke Brill NV provided that the appropriate fees are paid directly to The Copyright Clearance Center, 222 Rosewood Drive, Suite 910, Danvers, MA 01923, USA. Fees are subject to change.

This book is printed on acid-free paper and produced in a sustainable manner. 


\section{Contents}

List of Figures VII

Introduction IX

Michael Peachin and Daniëlle Slootjes

\section{PART 1}

\section{Politics \& Military}

1 Rome, Pontus, Thrace and the Military Disintegration of the World Beyond the Hellenistic East 3

Toni Ñaco del Hoyo and Isaías Arrayás-Morales

2 Estranging the Familiar-Rome's Ambivalent Approach to Britain 20 Gil Gambash

3 Rome and Persia in the Middle of the Third Century AD (230-266) 33 Lukas de Blois

4 The Emperor Beyond the Frontiers: A Double-Mirror as a 'Political Discourse' 45

Stéphane Benoist

\section{PART 2}

Politics, Economics, \& Society

5 Turning the Inside Out: The Divergent Experiences of Gaul and Africa during the Third Century AD 67

Dan Hoyer

6 Raiders to Traders? Economics of Integration among Nomadic

Communities in North Africa 96

Wim Broekaert and Wouter Vanacker

7 Transfer römischer Technik jenseits der Grenzen: Aneignung und Export 123

Günther Schörner 
8 Perceptions from Beyond: Some Observations on Non-Roman Assessments of the Roman Empire from the Great Eastern Trade Routes 151

Anne Kolb and Michael A. Speidel

9 Hospitium: Understanding 'Ours' and 'Theirs' on the Roman Frontier 180 John Nicols

\section{PART 3}

Material Culture and Culture

10 Palmyrenes in Transtiberim: Integration in Rome and Links to the Eastern Frontier 193 Blair Fowlkes-Childs

11 Rival Powers, Rival Images: Diocletian's Palace at Split in Light of Sasanian Palace Design $\quad 213$

Anne Hunnell Chen

12 The Reception of Figurative Art Beyond the Frontier: Scandinavian Encounters with Roman Numismatics 243

Nancy L. Wicker

Index of Places 257

Index of Names 259

General Index $\quad 261$ 


\section{List of Figures}

6.1 Export to northern regions 105

6.2 Imports from northern regions 106

6.3 Exchange with southern regions 114

6.4 Mediatory trade between North Africa and Sahel 115

7.1 Übersicht zu Modalitäten des Techniktransfers nach dem entwickelten Fragenkatalog 147

10.1 Fragment of marble relief for Bel and Iarhibol, and probably Aglibol. $20 \times 34 \times 3 \mathrm{~cm}$. Rome, Musei Capitolini 198

10.2 Fragment of marble relief with head of Astarte. $12 \times 18 \mathrm{~cm}$. Rome, Musei Capitolini 2970199

10.3 Marble aedicula for Aglibol and Malakbel. February $236.97 \times 63 \mathrm{~cm}$. Rome, Musei Capitolini $1206 \quad 202$

$10.4 \quad 4$ a and b. Sol/Malakbel Altar. $84 \times 5^{2} \times 5^{2} \mathrm{~cm}$. Rome, Musei Capitolini, NCE 2412. 4c and d. Sol/Malakbel Altar. 204

10.5 Cippus for Sol. Musei Vaticani 207

10.6 Detail of Giambattista Nolli's 1748 Pianta di Roma. The Vigna Crescenzi (later named the Vigna Bonelli) is circled 211

11.1 Plan of Diocletian's Palace at Split, highlighting the main north-south and east-west roads, towers and fortress walls. Plan adapted from Ćurčić, $2010 \quad 215$

11.2 The North “Golden" Gate. Diocletian's palace, Split. Photograph courtesy of Samuli Lintula; Creative Commons Attribution ShareAlike $3.0 \quad 216$

11.3 "Felix Romuliana" inscription excavated at the Late Roman palace near Gamzigrad, Serbia. Photograph courtesy of the National Museum, Zaječar 219

11.4 Plan of the Late Roman palace near Gamzigrad, Serbia. Plan adapted from Ćurčić, $2010 \quad 219$

11.5 Plan of the unfinished curtain wall from the Late Roman complex discovered near the village of Šarkamen in eastern Serbia. Plan adapted from Ćurčić, $2010 \quad 220$

11.6 Brick stamped in the name of the Fifth Macedonian legion. From the Late Roman palace near Gamzigrad, Serbia. Photograph courtesy of the National Museum, Zaječar 222

11.7 Plan of the palace of Ardashir I at Firuzabad. Early third c. AD. Demonstrating the organizational layout that became characteristic of early Sasanian palaces. Plan adapted from Huff $2008 \quad 226$ 
11.8 Throne room at the palace of Ardashir I, Firuzabad. Square room with a domed roof executed in pitched courses of mudbrick. Photograph courtesy of Ali Majdfar 227

11.9 Plan of Diocletian's palace, Split. Plan adapted from Ćurčić, $2010 \quad 228$

11.10 View through the sunken peristyle to the protyron. Diocletian's palace, Split. Photograph courtesy of Carole Raddato, via Wikimedia Commons/cc-by-sa 229

11.11 Domed roof of the 'Throne Room,' Diocletian's palace, split. Executed in pitched brick technique. Photograph courtesy of Carole Raddato, via Wikimedia Commons/cc-by-sa 230

11.12 Depiction of the palace at Ctesiphon. From the so-called Great Historical Panel IV on the southwest side of the Arch of Septimius Severus, Rome. Early third century. After Brilliant 1967, pl. 91a. Reproduction courtesy of the American Academy in Rome 231

11.13 Pitched brick dome in a basement room of the residential apartments, Diocletian's palace, Split. The technique of executing domes with pitched courses of brick is unknown in imperial architecture before the Tetrarchic period and probably came to the Roman Empire from the east. Author's photograph 233

11.14 Great Trajanic Frieze, 2nd c. AD, reused on the Arch of Constantine, Rome. (C) The Trustees of Columbia University, Media Center for Art History, Department of Art History and Archaeology 236

11.15 Equestrian duel relief. Arch of Galerius, Thessaloniki. Author's photograph 236

11.16 Equestrian duel between Sasanian King Bahram II and a challenger, bas relief from Naqsh-i Rustam. Third century AD. Photograph courtesy of Helen Evans 238

11.17 Sardonyx cameo featuring the Sasanian King of Kings capturing Emperor Valerian. Bibliotheque Nationale de France, Cabinet des médailles, inv. Babelon 36o. Photograph courtesy of Marie-Lan Nguyen, via Wikimedia Commons/cc-by 239

12.1 Medallion imitation (IK 107) 246

12.2 Medallion imitation (IK 14) 246

12.3 Type A bracteate with runic inscription 248

12.4 Full-face human head on Type B bracteate (I 190) 253

12.5 Profile heads on Type B bracteate (IK 143) and Type C bracteate (IK 144,1) 253 


\section{Introduction}

\section{Michael Peachin and Daniëlle Slootjes}

In recent years, historians of ancient Rome have been much occupied with the matter of identity. How do we recognize or delineate a group of people, whom we would be satisfied to call the Romans; or, how do we isolate a state of being Roman? How did people negotiate that identity, as well as others, in antiquity? What roles did identity play—socially, politically, economically, culturally, religiously? Furthermore, it is also clear that people-modern as well as ancient-had multiple identities, which they might take up depending on the particular situation of the day or environment. On a cautionary note, our modern need to understand the ancient by way of the notion of 'identity' does not necessarily match a similar ancient need.

The Impact of Empire group has approached this realm obliquely via several of its workshops, and the resultant volumes. Thus, there have been examinations of Roman frontiers (IMEM volume 13), of integration in the Roman world (IMEM volume 17), or of Roman rule as it was represented in Greek and Latin texts (IM EM volume 18). In any case, the sense that this matter of identity, and identity formation, is greatly significant led to a desire to approach this complex from yet another angle, namely, interactions between those from within and those from beyond the Roman frontiers. It also seemed that the astonishingly cosmopolitan environment of New York was perhaps the logical venue for such a group of papers. Thus was born the present volume, which derives from a workshop held in New York in June of 2013, and which seeks to tackle the issue of Rome and the worlds beyond Roman frontiers. Apart from thanking the participants for their many perceptive comments during the discussions at the workshop, we are particularly grateful to Olivier Hekster for his work in the actual realization of this volume.

Now, when this particular theme was selected for the New York workshop, those contemplating the submission of a paper were encouraged to think as widely as they liked in determining just what might be implied both by "Rome," or by "the worlds beyond Roman frontiers." They were told to approach interactions between these two realms from whatever perspective seemed fruitful. In short, the net for this workshop was cast widely. Such a set of instructions was of course likely to result in a group of papers, which would be, so to speak, all over the map. That eventuality, though, seemed an interesting and potentially fruitful gamble. In any case, the result was exactly as had been anticipated. 
The range of paper topics was indeed wide, both in subject matter and in approach; and thus, the scope of the present volume is likewise expansive.

That said, a number of common themes do indeed serve to bind the essays into a reasonably coherent whole. In particular, the various ramifications of one particular matter surface repeatedly, albeit in differing guises, throughout. Who is an insider, and who the outsider? How were these categories of person, or identity, fashioned and/or recognized in antiquity? How shall we recognize them now? What are the categories, or standards, for measuring or determining inside and outside in the Roman world? And then, of course, what are the repercussions when inside and outside come into contact? What happens when the outside is in, or the inside out? The contributors here can, at one moment, focus on the city of Rome, and ask these sorts of questions. At another moment, the focus can lie, geographically, well beyond the actual frontiers of the empire. Either way, though, the same basic set of questions can easily be asked. In the end, the papers divided themselves neatly into three essential groups, and they are published accordingly in this volume.

A first four contributions tackle the inside/outside dichotomy by peering through the combined lenses of politics and the military. Regions on the borders in the Eastern and Western half of the Empire are of particular interest in these contributions. Toni Ñaco del Hoyo and Isaías Arrayás-Morales present an analysis of the way in which Rome dealt with the regions of Pontus and Thrace in the last two centuries of the Republic. Their contribution offers an assesment of Rome's political and military strategies in trying to integrate these regions into the Imperium Romanum. Gil Gambash takes his reader to the western frontier of the Empire in his attempt to understand the ambivalent attitude towards and perception of Britain by the Romans in the first century AD. The island's location at the outskirts of the Empire seems to have sparked — what Gambash calls — a century of 'atypical imperial inaction'. Lukas de Blois examines a long and dangerous conflict at the eastern edges of the empire in the third century, between the Persians and the Romans. The Persian actions forced several of the many Roman emperors of the third century to react to and act upon the Persians which took away their attention from other important issues in other parts of their empire.

The fourth contribution in this section, by Stéphane Benoist, brings together several of the issues touched upon by the other three contributions, in that Benoist offers a broader perspective on imperial power and 'imperial discourse' in the period between Augustus and Theodosius II. He discusses the difficulties we have in our attempt to obtain an understanding of the 'outside' perceptions and perspective of the Romans, and in particular perceptions of the princeps, as the evidence remains predominantly Roman, even though we get some glimpses from the outside. 
The next group of five papers again takes up political themes, often envisioning these in combination with economics or society. Thus, Daniel Hoyer looks at two flashpoints in the history of the third century crisis: the revolt of the Gordians in 238, and Postumus and the Gallic Empire later in the century. In the case of the former, the breakaway was not from the Roman Empire altogether, but simply from the reign of one specific emperor, namely, Maximinus Thrax. In Gaul, things played out much differently. There, a group of insiders left the fold, self-consciously became outsiders, but nonetheless shaped themselves precisely in the form of the inside. In short, two different uprisings played themselves out in significantly different ways along the inside-outside axis. Hoyer argues that differing economic situations in these two regions played a significant role in determining this particular course of events. Wim Broekaert and Wouter Vanacker stay in the western half of the Empire, but move in their contribution to North-Africa where they studied the economic interactions between the Roman civic and military settlements and the sub-Saharan kingdoms. They argue that modern scholarship so far has misjudged the intermediary role of nomads within these economic interactions. Broekaert and Vanacker apply an anthropological model of interaction between nomadic and settled communities to a case study on the role of the Garamantes in the economy of Roman Africa.

Günther Schörner continues this section with a contribution that demonstrates how the use of technologies in a broad range of artefacts and production techniques was transferred in many more areas than modern scholarship so far has analyzed. The broad range of materials and locations allows Schörner to discern patterns in the ways in which Roman techniques were spread within and outside of the Empire. Apart from a presentation of archaeological evidence, in the second part of his contribution Schörner also applies modern ideas of conceptual and complete technology, appropriate and high technology, and practical and prestige technology, which are part of modern studies on technology.

The joint contribution by Anne Kolb and Michael Speidel focuses on the application of notions of transcontinental connectivity onto the Roman Empire, in particular in relation to the great Eastern trade routes. Their contribution brings us far beyond the frontiers of the Roman Empire into Asia, Arabia, India and China. They make clear that in the far East and China fairly detailed information was known about the Roman Empire, which makes them plea for further research and in particular cooperation between scholars of the various areas and disciplines such as Sinology and Classics.

Finally, John Nicols moves to the geographic edges of the empire, and looks at the workings of hospitality there. Both those, who can be called Romans, and those, who were not to be labeled thus, knew institutions, which might fall 
under the category of Roman-style hospitium. Thus, this one social construct worked well to allow those inside and those beyond the frontiers (both in a physical and in a cultural sense) to communicate, to get along with each other, to use similar socio-political institutions to construct their relationships.

A last group of papers comes at the theme of this volume from the perspective of material culture. Blair Fowlkes-Childs examines outsiders at Rome. In particular, her concern involves the cultic sites of several Palmyrene deities in the Transtiberim vicinity of Rome. How are we to imagine these religious installations? Are the folks responsible for them still outsiders, despite their residence in the capital? Or, have they integrated in some manner, which would make of them insiders? We are confronted here, of course, by the thinking of a man like Juvenal, and must then decide who the real Romans were. Anne Hunnell Chen brings in a new archaeological and art historic perspective on Diocletian's palace in modern Split as she aims to show how parallels between Roman and Sasanian palatial architecture were of influence on the ways in which Diocletian envisioned his palace. Imperial architecture offered an interesting avenue for the negotiating of power relationships between Rome and her enemies.

The final contribution, by Nancy Wicker, brings in one more area that has so far not gotten attention in this volume, which is Scandinavia, an area that had many contacts with the Roman Empire as well. She demonstrates how the presence of late Roman medallions in the North inspired the design of the Scandinavian gold bracteates in the fifth and sixth centuries AD. Wicker analyzes the possible influence of the imagery of the medallions on the images of the bracteates that then develop their own distinctive ornamentation. 
PART 1

Politics \& Military

$\because$ 



\title{
Rome, Pontus, Thrace and the Military Disintegration of the World Beyond the Hellenistic East
}

\author{
Toni Naco del Hoyo ${ }^{1}$ and Isaías Arrayás-Morales
}

The aftermath of the Gracchan crisis was a period of intense turmoil in many regions of Roman domain, East and West, although the loss of historical narratives such as those of Polybius and Livy have managed to shadow the scope of the troubles faced by the Republic during this period. Whereas the Cimbrian and Teutonic invasions and some regional conflicts in Sicily, Sardinia, Spain and Gaul kept the Roman armies busy in the West, in the East Macedonia, the Balkans and Asia, things were also extremely unsettled. It is possible to observe how the aftermath of certain dynastic conflicts and the ambitious political programmes endeavoured by some rulers in pursue of hegemonic dreams, as well as the continuous raids of nomadic peoples from beyond the Roman borders, directly agitated the entire region for decades. Specifically, Mithridates VI Eupator king of Pontus and several Thracian kings envisioned Rome's more active presence in Macedonia and Asia during the final decades of the second century $\mathrm{BC}$ as a threat to their military supremacy. Thus far, they had displayed garrisons and colonies, organized looting expeditions and systematically recruited foreign mercenaries for their reinforced armies. At this point, however, the Late Roman Republic's more active military policies concerning the region began to jeopardize their hegemony.

We should recall that two long-term interconnected phenomena in the Eastern Mediterranean had already caused distressing effects on neighbouring populations whose aggressive powers eventually attempted to dispute Rome's increasingly hegemonic role within the region. Firstly, the Hellenistic kingdoms had been suffering from a progressive political disintegration since the early second century. Secondly, the Roman armies had considerably increased their activities in continental Greece ever since the mid-second century, also being in charge of securing the Macedonian borders. Therefore, of relevance

1 Toni Ñaco del Hoyo is an Icrea Research Professor at Universitat de Girona. Isaíais ArrayásMorales is an Associate Professor at Universitat Autònoma de Barcelona. This research has been made possible by the following research grants: 2014SGR 1347, HAR2014-59503-P, and har2013-41629-P/Hist. All dates are BC unless otherwise indicated. 
here is the actual dimension of Roman imperialism in the face of certain new and at first sight short term challenges which however turned out to be only a snapshot of a much longer and more complex phenomenon. Furthermore, Rome was increasingly more aware of its global dominion over the oikumene which gradually evolved from hegemony in interstate relations early in the second century to what we might call a 'territorial empire' a century later, during Cicero's time: imperium orbis terrarium, eui imperio omnes gentes reges nations... consenserunt (Cic. ad Her. 4.13). ${ }^{2}$

For decades, studies of Roman imperialism have intensively examined how Rome's hegemony in the East emerged and succeeded over the last two centuries of the Republic, but our aim here is not to reappraise this lengthy debate in its entirety. ${ }^{3}$ Rather, we intend to assess the political and military strategies conducted by the Republican authorities, but only during a few decades during that same period. We wish to argue here that such strategies would eventually help Rome to integrate both Pontus and Thracia into the Imperium Romanum, especially once peace was finally reached. On the one hand, Mithridates VI Eupator, king of Pontus (120-63), a long time a close ally of Rome, had the ambition to play a central role in the agitated scenario of the interstate relations within the Black Sea region, deploying garrisons in numerous towns, promoting an interventionist dynastic policy in some of the neighbouring kingdoms, and directly defying Rome during war. Despite the treaties already signed with cities such as Mesembria, Callatis and Chersonesos, Rome's interests were bound to clash with Mithridates' expansion towards the Thracian coast, and his quest for new resources. His next claims over Paphlagonia, Galatia and Cappadocia were eventually responded to in tough diplomatic and military terms. But, despite his long lasting friendship with Mithridates, is it possible that Rome never foresaw his actual ambitions towards the western and northern Black Sea coasts?

2 See also Cic. Off. 2.27. P.A. Brunt, 'Laus Imperii', Roman Imperial Themes (Oxford 1990), pp. 291293, 297-300; G. Kellon, 'The rise of Global Power and the Music of the Spheres: Philosophy and History in Cicero's De re publica', in D.E. Tabachnick, T. Koivukoski (eds.), Enduring Empire. Ancient Lessons for Global Politics (Toronto 2009), pp. 147-163; D.J. Mattingly, 'From imperium to imperialism', Imperialism, Power and Identity. Experiencing the Roman Empire (Princeton 2011), pp. 3-42; L. Beness, T. Hillard, 'Rei militaris virtus ... orbem terrarium parere huic imperio coegit: The Transformation of Roman Imperium, 146-5o BC', in: D. Hoyos (ed.), A Companion to Roman Imperialism (Leiden-Boston 2013), pp. 141-153.

3 See, most recently A.M. Eckstein, Mediterranean Anarchy, Interstate War, and the Rise of Rome (Berkeley 2006), pp. 79-117; D.W. Baronowski, Polybius and Roman Imperialism (London, 2011), pp. 71-72; O. Hekster, 'Kings and Regime Change in the Roman Republic', in Ch. Smith \& L.M. Yarrow (eds.), Imperialism, Cultural Politics \& Polybius (Oxford, 2012), pp. 184-202. 
On the other hand, the decay and eventual extinction of most of the Hellenistic monarchies as employers for mercenaries and auxiliaries from the Thracians and other nomadic tribes led to a major disturbance within and beyond their frontiers. It is not surprising to see how the Thracians, Sarmatians and Scordisci eventually moved from the steppes of Southern Ukraine to raid Macedonia, Illyria and other regions under Roman control. Yet, though some Thracian auxiliaries were recruited during the Mithridatic Wars, Rome never became a proper mercenary employer as the old Hellenistic powers used to be. So, the open confrontation against the Thracians in several wars from the late second century was Rome's last resort to resolve the unrest caused by their continuous raids into Roman territory when it was not feasible to enrol these individuals as mercenaries?

\section{1 \\ Towards the Integration of the Pontic Territories in the Roman World}

Rome showed interest in the eastern Mediterranean ever since the earliest phases of Republican expansion towards the Hellenistic world. But it was not until the leadership of Gaius Marius and his supporters that Rome itself engaged in the area of the Black Sea, as a result of the aggressive expansion undertaken there by king Mithridates of Pontus. Rome could have ordered the withdrawal of the Pontic monarch from the territories conquered to the Scythian kings, as occurred in regards to the Anatolian regions of Paphlagonia and Cappadocia (Memn. 22.3-4). However, evidence suggests that Mithridates' early victories in the Bosporus and Colchis, and his triumphs over Scythians, Sarmatians, Bastarnae, and other northern Black Sea populations were not a cause for alarm in Rome. Thus, the king was free to proceed with his policy. This lax attitude on behalf of Rome may be explained by the fact that these were distant lands, in which the Senate clearly had no interests. Also, his status as a "friend and ally" of Rome meant that his raids indirectly served to extend Roman hegemony to those regions. Furthermore, between 113 and 101, Rome was engaged in wars against the Numidian king Jugurtha, and against the Cimbrians, who were now threatening the territory of Italy. No doubt, this difficult political and military situation in the West surely played a role in Rome's laissez-faire approach to Pontic expansion in the Black Sea, and also promoted Mithridates' intervention in Anatolia. ${ }^{4}$

4 A.N. Sherwin-White, Roman Foreign Policy in the East 168 BC to AD 1 (London, 1984), pp. 106-107, 134; B.C. McGing, The Foreign Policy of Mithridate VI Eupator (Leiden, 1986), pp. 37-38, 
The king's raids of Anatolia finally compelled Rome to react, and marked the beginning of the escalation leading to the Mithridatic wars. Clearly, Rome could not tolerate a powerful and hostile Pontic kingdom on the border of such an important province as Asia. It had already taken steps to constrain this possibility, such as the addition to the province of all the lands of the Attalid kingdom rendered in 129/126 to the kings of Pontus, Cappadocia and perhaps Bithynia, all of whom were allies in the war against Aristonicus (Str. 10.4.10; App. Mith. 11-13, 15, 56; Iust. 37.1.6, 38.5.6). ${ }^{5}$ Also, Rome was forced to contend with Mithridates' increasing prestige in the Greek world, at a time when antiRoman sentiment was on the rise, generated in large part by the rapacity of the Italian businessmen. ${ }^{6}$ Thus, it is not surprising that the Athenians honored him with an inscription in Delos, and even with a small temple in 102/101. ${ }^{7}$ Likewise, Chiotians and Rhodians erected statues and produced inscriptions in his honor (Cic. Verr. 2.2.159). ${ }^{8}$ Such unrest in Anatolia dovetailed with the goals of the Marians, who, after the victory over Jugurtha and the Cimbrians, sought to restore Rome's honor through war, an ideal that was perfectly represented in the templum Honoris et Virtutis Marianum (Cic. Pro Sest. 116, Pro Planc. 78; Vitr. 3.2.5). ${ }^{9}$ All of this explains the rudeness with which Lucius Appuleius Saturninus treated the Pontic ambassadors dispatched to Rome in 102/101 (Diod. 36.15.1). It was followed in 99/98 by a diplomatic expedition of Marius to Galatia and Cappadocia, perhaps already anticipating a leading role in a potential war with Pontus (Plut. Mar. 31 ; Diod. 37.29.2). ${ }^{10}$ In any event, once Rome resumed its international leadership in the West in 101, it continued to

63-64, 66-88, 108, 173-175; R.D. Sullivan, Near Eastern Royalty and Rome, 10o-3o BC (Toronto, 1990), pp. 51-58; L. Ballesteros, Mitrídates Eupátor, rey del Ponto (Granada, 1996), pp. 43-71. RDGE 13; OGIS 436; IGRR 4, 752; Cnidos, col. III, ll. 22-27. T. Drew-Bear, 'Three Senatus Consulta concerning the Province of Asia', Historia 21 (1972), pp. 81-82; McGing, The Foreign Policy, pp. 41-42, 67-68; R.K. Sherk, Roman and the Greek East to the Death of Augustus (Cambridge 1984), pp. 53-54 (n. 49); M. Crawford, Roman Statutes (London, 1996), pp. 231-271 (n. 12).

6 McGing, The Foreign Policy, pp. 64, 89-108, 122.

7 OGIS 368-369; I. Délos 1560-1561, 1564-1568, 2039-2040; with a small temple in 102/101 see I. Délos 1552, 1569-1574, 1576, 1581-1582.

8 McGing, The Foreign Policy, pp. 89-93; P.-A. Kreuz, 'Monuments for the King: Royal Presence in the Late Hellenistic World of Mithridates VI', in Mithridates VI and the Pontic Kingdom (Aarhus, 2009), pp. 131-144.

9 A. Mastrocinque, Studi sulle guerre Mitridatiche (Stuttgart, 1999), p. 25; E. Bertrand, 'Sur les couronnes de Sylla (et sur la couronne civique à la fin de la République romaine et au début du Principat)', in Hommages à François Hinard (Paris, 2010), pp. 23-38.

10 T.J. Luce, 'Marius and the Mithridatic Command', Historia 19 (1970), pp. 166-168; M. Sordi, 'La legatio in Cappadocia di C. Mario nel 99-98 a.C.', RIL 107 (1973), pp. 370-379; McGing, The Foreign Policy, pp. 59, 71-72, 76; Mastrocinque, Studi sulle guerre, pp. $25^{-27}$. 
avoid taking any harsh measures against Pontic expansion in the Black Sea. In addition, it should be noted that Mithridates, as a "friend and ally", attempted to maintain diplomatic ties with the Roman state, leaving, at least in part, his plans of expansion in Anatolia. Furthermore, during this period, Rome expressed a surprising lack of interest in Pontic affairs.

Indeed, it cannot be said that Mithridates implemented a hostile policy towards Rome. With his expansion in the Black Sea, as well as in Anatolia, the king went after the creation of a stronger Pontic State, exercising hegemonic power in the coastal lands along the Black Sea and neutralizing rival kingdoms. He carried out the same policies as all of his predecessors since Pharnaces I had done, all of whom had also been "friends and allies" of Rome. But his expansionist success led him to a sure collision with Roman interests in Anatolia. This may easily explain why his ties with Rome were maintained until the very last moment before the war. Actually, it is generally considered that he never in fact expected the attack on Pontus by Nicomedes IV of Bithynia in 89 (Memn. 22.7) at the instigation of the propraetor Gaius Cassius and the legate Manius Aquillius (App. Mith. 11; D.C. 99), both influential members of the Marians. Likewise, Cassius and Aquillius, without sufficient troops to start a war, were not expecting such a brutal response from a sovereign who had always complied with Rome's decisions (App. Mith. 19).11

Mithridates began his expansion along the coast of the Black Sea around 111/110, apparently with no significant political reaction in Rome, according to the scarce evidence existing on the matter. Therefore, although thus far the king had never betrayed the Republic's favour as a "friend and ally," he was determined to extend his power over Chersonesos Taurica, Olbia, Tyras, Theodosia, Pantikapaeum, Phanagoria, and Gorgippia (Str. 7.4.3-7). ${ }^{12}$ In doing so we should not deny that Mithridates, much like his predecessors, took advantage of the fragility of these poleis to the barbarians and also of Rome's inability to offer them effective assistance. Two decrees from Olbia refer to these affairs. The first, in honor of Neikeratos, noted the constant pressure put on the polis by the barbarians at the beginning of first century. ${ }^{13}$ The second, honoring a Pontic general from Amisos, indicated the presence of a Mithridatic garrison. ${ }^{14}$ As a reward for the campaigns that he led between 111 and 107, Mithridates

11 McGing, The Foreign Policy, pp. 80-83, 108-131; T.C. Brennan, The Praetorship in the Roman Republic, II (Oxford, 2000), pp. 555-556.

Syll ${ }^{3} 709 ;$ IOSPE $\mathrm{I}^{2} 35^{2}$.

Syll $^{3} 730 ;$ IOSPE $\mathrm{I}^{2} 34$.

IOSPE $\mathrm{I}^{2} 35$. McGing, The Foreign Policy, pp. 46-48, 50-57; V. Krapivina, 'Problems of the Chronology of the Late Hellenistic Strata of Olbia', in Chronologies of the Black Sea Area in the Period c. 400-100 BC (Aarhus, 2005), p. 251. 
was also crowned monarch of the Bosporus when its last ruler, Paerisades V, bestowed the kingdom upon him (Str. 7.3.17, 7.4.3-6; Iust. 37.3.1-2, 38.7.4-5). Along with these victories, around 105 and 100, the annexation of Colchis and Armenia Minor took place, granted by its king, Antipater (Str. 11.2.13, 11.2.18, 12.3.1, 12.3.28; App. Mith. 15, 17; Memn. 22.4; Iust. 38.7.10; Eutr. 5.1; Oros. 6.2.1). ${ }^{15}$

Eventually, territories along the northern and eastern coasts of the Black Sea were annexed and garrisoned by Pontus, and Mithridates appointed his sons and philoi as éparchoi in charge of them (Str. 7.4.3-7). Along the western coastline, on the other hand, Pontic hegemony was extended through alliances with the poleis (symmachiai). ${ }^{16}$ Thus, the proximity of the province of Macedonia must have served to limit his interventions. However, the serious problems affecting the province at the end of the second century, with its borders under constant threat by the barbarians, facilitated the king's activity in the region. Therefore, we have two inscriptions from the nineties, one from Istros and the other from Apollonia, honoring two Pontic strategists. ${ }^{17}$ In addition, several texts show that Marcus Terentius Varro Lucullus, proconsul of Macedonia in 72/71, forced most towns from the Thracian coast to capitulate (Liv. Per. 97; App. Illyr. 30; Sall. Hist. 4.18; Amm. 27.4.11; Eutr. 6.10; Fest. 9.3; Oros. 6.3.4) and accept the quartering of Roman garrisons, serving as proof of their bond with Pontus. ${ }^{18}$

In an unprecedented way, Mithridates attempted to unite the Black Sea under his control, in order to strengthen the link between these regions and the Pontus, and to promote the recovery of their economies after the end of the conflict with the barbarians. Thus, according to the evidence, the king was Chersonesos Taurica's protector (prostates) (Str. 7.4.3), intensifying the bond established by a previous treaty signed by Pharnaces I. ${ }^{19}$ Also, two decrees from Chersonesos report these circumstances: a decree in honor of a Pontic ambassador who had possibly brought the king's reply to the city's request for help;

15 McGing, The Foreign Policy, pp. 58-61; Ballesteros, Mitrídates Eupátor, pp. 53-54.

16 J.M. Hojte, 'The Administrative Organisation of the Pontic Kingdom', in Mithridates VI and the Pontic Kingdom (Aarhus, 2009), pp. 95-107.

17 AE 1997, 1316 = SEG 47, 1125; IGBulg. I $^{2} 392$.

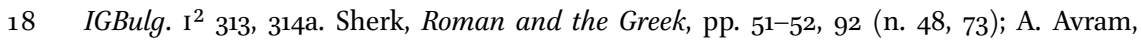
O. Bounegru, 'Mithridate VI Eupator et la côte ouest du Pont-Euxin. Autour d'un Décret inédit d'Istros', Pontica 30 (1997), pp. 155-165; Brennan, The Praetorship in the Roman, pp. 521-522, 528-533, 560-564, 584; P. Delev, 'The burning of the temple at Delphi, the Roman governor L. Scipio and the rout of the scordisci', in Armées grecques et romaines dans le nord des Balkans (Gdansk, 2013), pp. 91-103.

19 IOSPE $\mathrm{I}^{2}$ 402. J.M. Hojte, "The Date of the Alliance between Chersonesos and Pharnakes (IOSPE $\mathrm{I}^{2}$ 402) and its Implications', in Chronologies of the Black Sea Area in the Period c. 400-100 BC (Aarhus 2005), pp. 137-152. 
and a decree honoring the general Diophantos, who took part in three campaigns in Taurica (Str. 7.4.3-7). ${ }^{20}$ Specifically, the latter document reflects the troubles of Chersonesos, and of the other towns in the area, since the barbaric pressure at the end of second century. It also shows the gratitude of the city's population towards the Pontic troops that had helped defend them, despite eventually losing its freedom. ${ }^{21}$

It should also be noted that, since the last decade of the second century, the king's coinage spread over the regions under his control. These coins came primarily from Amisos and, to a lesser extent, from Sinope, indicating that there was an attempt to strengthen economic and politic relations in the Black Sea region. It should be stressed that the coastal regions, especially the northern ones, were allowed to overcome the deep crises that they were suffering from, due to the barbarian threat, with trade even being encouraged with the inland tribes, in which the poleis acted as third party. Therefore, these lands became an essential source of supplies, permitting the king's long war against Rome (Str. 7.4.6, 11.2.18; App. Mith. 69; Memn. 32-38). However, once again, they fell into decline following the war destruction in 63 , as well as a result of factors such as poor management by the Pontic satraps, the blockade raised by Pompeius Magnus, and the tax demands imposed upon them by Mithridates. Thus, for him, once expelled from Anatolia, the Bosporus became his principal possession. $^{22}$

\section{Rome and the Thracians at the Beginning of the Late Roman Republic}

Located in the Eastern Balkans, between the Danube in the North (Istros, in Greek) and the Aegean in the South, the Thracians were an amalgamation of

$20 \quad$ IOSPE I I ${ }^{2} 349$; Syll ${ }^{3} 709 ;$ IOSPE $\mathrm{I}^{2} 35^{2}$.

21 P. Foucart, 'Décret de la ville de Chersonesos en l'honneur de Diophantos, Général de Mithridate', $B C H 5$ (1881), pp. 70-87; L. Boffo, 'Grecità di frontiera: Chersonasos Taurica e i signori del Ponto Eusino (sIG 3 709)', Athenaeum 67 (1989), pp. 211-259, 369-405; J.A. Vinogradov, 'Two Waves of Sarmatian Migrations in the Black Sea Steppes during the Pre-Roman Period', in The Cauldron of Ariantas (Aarhus, 2003), pp. 217-226.

M.J. Price, 'Mithridates Eupator Dionysos and the Coinages of the Black Sea', NC 8 (1968), pp. 1-12; F. de Callataÿ, 'Coins and Archaeology. The (mis)use of Mithridatic Coins for Chronological Purposes in the Bosporan Area', in Chronologies of the Black Sea Area in the Period c. 400-100 BC (Aarhus, 2005), pp. 119-136; S.J. Saprykin, 'The Unification of Pontos: the Bronze Coins of Mithridates VI Eupator as Evidence for Commerce in the Euxine', in The Black Sea in Antiquity (Aarhus, 2007), pp. 195-207. 
tribes contemporary to the Greek and Roman world. There is little agreement as to whether or not the Thracians shared an Indo-European language, ethnicity, culture and a lifestyle based on their strong dominion of warfare and horses. There is still much to be understood about their political organization, except for the Ordrysian tribe whose royal institutions have been well attested to since the sixth century, thanks to the interest of some classical authors. ${ }^{23}$ Although most of our historical record has been provided by the archaeology, coins and art of such people, literary evidence from the Graeco-Roman tradition provides an alien perspective that usually depicts the Thracians as skilled and fierce warriors and cavalrymen with a particularly brutal attitude towards its enemies at war. Never playing a minor role in foreign politics, for centuries the Thracians were often hired by neighboring powers and distant empires to serve as mercenaries and auxiliaries who efficiently devoted themselves to war and plunder on behalf of their employers. ${ }^{24}$

In this section of the paper we shall focus on the study of the role played by the Thracians as warriors on behalf of external powers in the Late Hellenistic period, when Rome decisively crossed the boundaries of 'multipolarity' in pursuit of a more hegemonic power in the East. In fact, the Republic's more direct intervention in Eastern affairs since early the second century slowly distorted

23 A. Fol, I. Marazov, Thrace \& The Thracians, (New York, 1977), pp. 144-154; Z.H. Archibald, The Ordrysian Kingdom of Thrace. Orpheus Unmasked (Oxford, 1998), esp. pp. 5-25, 93-125; 213-259; A. Hyland, 'War and the horses. Part I Horses for War. Breeding and keeping a Warhorse', in: B. Campbell, L. Tritle (eds.), The Oxford Handbook of Warfare in the Classical World (Oxford 2013), pp. 493-511 (pp. 493-494); D. Graninger, 'Etnicity and Ethne', in J. Valeva, E. Nankov, D. Graninger (eds.), A Companion to Ancient Thrace (Oxford 2015), pp. 22-32; Z. Archibald, 'Social Life of Thrace', Companion to Ancient Thrace, pp. 385-398 (pp. 393-395).

24 Ath. 4.155e; Hdt. 5.3; 6; Thu. 2.96-97; 7.29.4; Amm. 27.4.4; Flor. 1.39.3. M. Launey, Recherches sur les armées hellénistiques (Paris 1987), reipr. 1949, vol. 1, pp. 366-398 (pp. 386-389); Ch. Webber, The Thracians 700 BC-AD 46, Osprey Men-at Arms 360 (Hailsham 2001); S. Kirov, 'L'image des Thraces à Rome du IIè.s. avant au IIIè.s. après N.E.', in Proceedings of the 1oth International Congress of Thracology (Komotini-Alexandrooupolis 18-23 October 2005) (Athens, 2007), pp. 304-307; D. Dana, 'Les Thraces dans les armées hellénistiques: essai d'histoire par les noms', in J.-Ch. Couvenhes, S. Crouzet, S. Péré-Noguès (eds.), Pratique et identities culturelles des armées hellénistiques du monde méditerranéen, Scripta Antiqua 38 (Bordeaux, 2011), pp. 87-115 (pp. 88-90); A. Sobotkova, 'Resisting rule in ancient Thrace', in M. Manoledakis (ed.), Exploring the Hospitable Sea. Proceedings of the International Workshop on the Black Sea in Antiquity held in Thessaloniki, 21-23 September 2012, BAR Int.Ser. 2498 (Oxford, 2013), pp. 133-146 (pp. 134-136). 
the traditional picture of the Thracians as fortune warriors and looters. ${ }^{25}$ According to Livy, the Roman legions in Magnesia were reinforced by 2,00o Thracian and Macedonian 'voluntary soldiers' (qui voluntate secuti erant), whatever the exact meaning of such 'voluntary' service may have been, possibly referring to soldiers enrolled following the clauses of any alliance treaty not explicitly mentioned in the same passage (Liv. 37.39.12). ${ }^{26}$ Therefore, unlike what was a common practice for most of the Hellenistic monarchies thus far, mercenary trade was hardly at the core of Roman and Thracian relations during the first decades of Republican expansionism to the East. Our data seems to suggest that this issue remained constant over the following decades and would not change until Thrace became a Roman province during the Roman Principate.

Although L. Scipio (cos. 190) headed for Thrace with Macedonian support in 190 (Liv. 37.7.16), Rome's first military encounters with the Thracians are dated back to 188. Then, Cn. Manlius Vulso (cos. 189) who had been in charge of the Roman-Aitolian peace, led an expedition to Hellespont, Chersonese and Thrace, being ambushed several times by the Thracians but ultimately defeating them (Liv. 38.40-41). ${ }^{27}$ Later, Perseus of Macedon employed Thracian soldiers in his armies during the final war against Rome, while at the same time, the latter strengthened its diplomatic ties with several Thracian tribes, seeking external support for his cause (Liv. 42.19.6). ${ }^{28}$ But, after the defeat at Pydna in 168, the entire Macedonian court was captured and deported to Rome and a Thracian prince called Bithys, son of king Cotys viII, was among the distinguished individuals imprisoned in Rome. Nevertheless, instead of following Perseus' dramatic destiny, the Republican authorities merely held Bithys as a hostage for some time, being advisedly educated before sending him back to his father in Thrace (Liv. 45.42.5-12). ${ }^{29}$

25 See most recently, P. Delev, 'From Koroupedion to the Beginning of the Third Mithridatic War (281-73 BCE)', in J. Valeva, E. Nankov, D. Graninger (eds.), A Companion to Ancient Thrace (Oxford, 2015), pp. 59-74 (pp. 68-72).

26 J. Krasilnikoff, 'Mercenary soldiering in the West and the development of the army of Rome', Analecta Romana Instituti Danici, 23 (1996), pp. 7-20 (p. 15).

27 J. Briscoe, A Commentary on Livy Books 38-40 (Oxford, 2008), p. 148; M. Zahariade, The Thracians in the Roman Imperial Army. From the first to the third century AD, vol. I, Auxilia (Cluj-Napoca, 2009), pp. 39-40.

28 M. Zahariade, The Thracians, p. 42.

29 Syll ${ }^{3}$ 656; D.C. Braund, Rome and the Friendly King (London, 1984), p. 16; C. Eilers, 'Introduction', in C. Eilers (ed.), Diplomats and Diplomacy in the Roman World (LeidenBoston, 2009), p. 9. 
It should be stressed that in the aftermath of Perseus' defeat, Rome imposed its unilateral conditions on a Thracian king who had formerly been under Macedonian influence. From this moment on, the slow but progressive decay of Thracian mercenary recruitment by foreign powers became a decisive side effect of Rome's growing dominion over the East. For instance, Andriscus, the pretender to the Macedon throne who led an uprising against Rome in 150, actually received active military support from some Thracian tribes. Two years later, after being defeated in Macedonia, Andriscus fled to Thrace, seeking refuge and being finally betrayed by Byzes, a Thracian prince (Zon. 9.28). ${ }^{30}$ Although some Greek towns continued to enroll Thracian soldiers, when the military hegemony of the Hellenistic monarchies diminished and eventually vanished, particularly during the second half of the second century BC, the actual number of potential employers also followed the same pattern. Accordingly, there was major stress in the daily lives of many Thracians who had previously serve as mercenaries in regular foreign armies outside of Thrace. ${ }^{31}$

In 141 some raids from the Scordisci, Celtic Gauls known even in Strabo's time for their occupation as brigands (Str. 7.5.12), ${ }^{32}$ were briefly reported on in Livy's summaries (Liv. Per. 54), along with new actions undertaken to defend such territories in 135 when again only a few lines in Livy outline a Roman expedition led by M. Cosconius, a praetor serving in the Roman province of Macedonia that year and who defeated the same nomadic people (Liv. Per. 56). ${ }^{33}$ According to the historical record, these raids ceased for some

30 L.D. Loukopoulou, 'Provinciae Macedoniae Finis Orientalis. The Establishment of the Eastern Frontier', in M.B. Hatzopoulos \& L.D. Loukopoulou, Two Studies in Ancient Macedonian Topography (Athens, 1987), pp. 61-110, esp. p. 68; R. Kallet-Marx, Hegemony to Empire. The Development of the Roman Imperium in the East from 148 to 62 BC (BerkeleyLos Angeles-Oxford, 1995), pp. 34-37.

31 K. Sion-Jenkins, 'La disparition du mercenariat en Asie Mineure occidentale au IIè. Siècle a.C.: éléments de réflexion', in A. Bresson, R. Descat (eds.), Les cités d'Asie Mineure occidentale au IIè. Siècle a.C. (Bordeaux, 2001), pp. 19-35; contra. J.-Ch. Couvenhes, 'Les cités grecques d'Asie Mineure et le mercenariat à l'époque hellénistique', in J.-Ch. Couvenhes \& H.-L. Fernoux (dir.), Les cités grecques et la guerre en Asie Mineure à l'époque hellénistique (Tours, 2004), pp. 77-113 (pp. 105-106).

32 R. Kallet-Marx, Hegemony to Empire, p. 38. See recently, J. Emilov, 'Celts', in J. Valeva, E. Nankov, D. Graninger (eds.), A Companion to Ancient Thrace (Oxford 2015), pp. 365-381 (pp. 374-375).

33 T.C. Brennan, The Praetorship, vol. 1, pp. 227-229 and pp. 345-346; M.-G. Parissaki, 'Thrace under Roman sway (146 BC-AD 46) between warfare and diplomacy', in A. Rufin Solas (ed.), Armées grecques et romaines, pp. 105-114 (pp. 106-108). 
time but they surely meant a serious affront not only on the provincial territories of Macedonia themselves, but also for Rome's growing interest in the East. ${ }^{34}$

During roughly the same period, most likely over the third quarter of that century, a new road-building program (known to us as via Egnatia) was launched in Illyria and Macedonia. ${ }^{35}$ As had previously occurred in Italy or in other Mediterranean regions during the last quarter or that same century, roads were necessary in order to accomplish military objectives by securing the quick mobility of the legions and their supplies. Only when such roads were fully operative and the unrest eventually diminished due to the presence of the armies, could private businessmen also travel across them, in search of new markets. Traders and entrepreneurs of Italian or Roman origins had already settled in Macedonia and Illyria over the second half of the century, and they surely made use of such transport resources when necessary. ${ }^{36}$ In fact, M.H. Crawford points out that the huge quantity of Roman denarii and Greek local issues hoarded in Dacia and Thrace since the mid-first century attests to the massive transactions related to slave trade, which were privately organized after the Thracian and pirate campaigns late in the second century. More recently, however, alternative but reasonable explanations have been suggested by A. Meta. Specifically, she relates the increased circulation in Dacia and Thrace of Roman issues as well as drachmae from Dyrrachion to payments for mercenary and auxiliary troops. ${ }^{37}$

34 L. Amela Valverde, 'Sexto Pompeyo, gobernador de Macedonia, y las incursions escordiscas ca. 120-100 a.C., Iberia 7 (2004), pp. 19-38 (p. 26).

35 F.W. Walbank, A Historical Commentary on Polybius, vol. 3 (Oxford, 1979), pp. 622-638; R. Kallet-Marx, 'Appendices. C. The date of the Via Egnatia', in Hegemony to Empire, pp. 347-349; Y. Lolos, 'Via Egnatia after Egnatius: imperial policy and inter-regional contacts', Mediterranean History Review 22.2 (2007), pp. 273-293 (pp. 274-275); A. Karivieri, 'Creating contacts. Trade and exchange along the Via Egnatia from the Roman to the early Byzantine period', Bollettino di archeologia on line [<http://151.12.58.75/archeologia $\rangle]$ 1 (2011) edizione speciale, C. 11.3., pp. 15-22.

$3^{6}$ A. Rizakis, 'Lémigration romaine en Macédoine et la communauté marchande de Thessalonique. Perspectives économiques et sociales', in Ch. Müller, Cl. Hasenohr (eds.), Les Italiens dans le monde grec. II e siècle av. J.-C.--Ir ap. J.-C., Suppl. всн (Athens, 2002), pp. 109-132 (pp. 110-112); S. Shpuza, 'Illyriens et romains. Du conflit à l'intégration', in A. Rufin Solas (ed.), Armées grecques et romaines, pp. 133-143 (pp. 140-141).

37 M.H. Crawford, 'Republican denarii in Romania: the suppression of piracy and the slave-trade', Journal of Roman Studies 67 (1977), 117-124; A. Meta, 'Guerre et circulation monétaire: le cas des drachmes de Dyrracchion', A. Rufin Solas (ed.), Armées grecques et romaines, pp. 117-131, (pp. 122 ff.). 
Triumphs over populations from the Balkans such as Delmatians in 155 and Iapydes in 129 are briefly mentioned in the Fasti Triumphales. ${ }^{38}$ The kingdom of Pontus became the main royal employer of mercenaries in the East, particularly following the extinction of the Attalid dynasty in 133 . Mithridates $\mathrm{V}$ Evergetes (c. 150-120) and a faithful ally of Rome's in Anatolia, sent one of his officers-Dorylaos-to recruit mercenaries in Thrace, Greece and especially in Crete, where the abundant mercenary soldiers of the island were also hired by pirate groups (Str. 10.4.10). ${ }^{39}$ After 133, the Thracians sided with Aristonikos (=Eumenes III) and joined his armies against Rome, serving as mercenaries, contributing to the consul P. Licinius Crassus Mucianus' defeat in 130 (Val. Max 3.2.12; Oros. 5.10.3)..$^{40}$ The Thracian incursions continued to cause great anxiety in Greek towns, as may be observed in a contemporary inscription from Sestos, a town located in the Thracian shore of the Hellespont. ${ }^{41}$ Similarly, according to another long-debated inscription from Lete, near Thessaloniki, dated 120/119, the Scordisci defeated a Roman commander called Sextus Pompeius, possibly a praetor. ${ }^{42}$ Unfortunately, the latter is only known thanks to this text. The full command of the remaining forces was left to Marcus Annius, Pompeius' quaestor, whose name is honored by this inscription. Annius managed to expel the invaders with the support of the Thracians Medii. ${ }^{43}$ The unrest in the Balkans was perhaps triggered by the initial expeditions of the Cimbrians and other Germanic tribes from Jutland to Thrace and Illyria, as well as by the alliance between Scordisci and some Thracians against the Romans. An extraordinary piece of what has been sometimes described as Thracian art from the last decades of the second century, the Gundestrup Cauldron, may offer indirect evidence for such migrations since it was located in Himmerland, Northern Jutland. However, this last historical interpretation

38 A. Degrassi, Fasti Capitolini. Recensuit, praefectus est, indicibus instruxit (Torino, 1955), pp. 105-106; D. Dzino, Illyricum in Roman Politics, 229 BC-AD 68 (Cambridge, 2010), p. 63, p. 72 .

39 F. Durrbach, Choix d'Inscriptions de Délos, t.I. (Paris, 1921), p. 156, pp. 217-218.

40 A.-J. Reinach, 'Les mercenaires et les colonies militaires de Pergame', Revue d'Archeologie 14.2 (1909) 55-70, esp. pp. 68-69; Ma.L. Sánchez León, 'Les Thraces dans les armées d'Eumène III de Pergame', in P. Roman (ed.), The Thracians at the crossroads of civilization: proceedings of the seventh international congress of thracology (Bucharest, 1997), pp. $392-398$.

41 OGIS 339, lin. 18; BE 1981, n. 328 (pp. 419-420); P. Delev, 'From Koroupedion', p. 69.

$42 \quad S I G^{3} 700 ; M R R$ I, 526.

43 F. Papazoglou, The Central Balkan tribes in pre-Roman times. Triballi, Autariatae, Dardanians, Scordisci and Moesians (Amsterdam, 1978) pp. 116-118; 288 ff.; L. Amela Valverde, 'Sexto Pompeyo, p. 27. 
is still controversial amongst the scholars who have studied the Cauldron, especially since it is only based on one single object, notwithstanding the fact that it contains precious and rare cultural images belonging to a world far from Jutland. ${ }^{44}$

Around 114/113, Rome faced some major new foreign policy challenges. Cimbrians and other Germanic peoples who had remained in Illyricum for some years headed towards the Alpine regions, Gaul, Spain and finally Italy in what has been recently described as the most dangerous invasion suffered by Rome's dominion since Hannibal. ${ }^{45}$ In addition to such massive migrations, we know of Jugurtha's war in Numidia, the uprisings in Further Spain and Sardinia, and a new slave uprising in Sicily. ${ }^{46}$ On the eastern front, however, the situation was little better, particularly, on the one hand, between 114 and 106 and on the other, until $97 .{ }^{47}$ Most of these events took place immediately after the Thracians and Scordisci raided Macedonia, Thessaly and even Dalmatia (Flor. 1.39.1). At any rate, such a stressful time in the Eastern provinces coincided with a period when the West was also in turmoil. ${ }^{48}$ For instance, according to Frontinus the Scordisci besieged and subsequently killed eight-hundred men and their Roman garrison commander-Lucullus-from a town called Heraclea (Front. 3.10.7). The passage does not provide any clear indication as to Heraclea's exact location or time. Nevertheless, it may possibly be attributed to Heracleia Sintike, a Greek town located between Macedon and Thrace

44 F. Kaul, 'The Gundestrup Cauldron and the Periphery of the Hellenistic World', in P. Bilde et alii (eds.), Centre and Periphery in the Hellenistic World (Aarhus, 1993) pp. 39-52 (pp. 47-49); S. Nielsen et alii, 'The Gundestrup Cauldron. New scientific and technical investigations' Acta Archaeologica 76 (2005), 1-58, (pp. 53-54).

45 Liv. Per. 63: Cimbri, gens vaga populabundi in Illyricum venerunt. See E. Demougeot, 'Linvasion des Cimbres—Teutons-Ambrons et les Romains' Latomus 37 (1978), pp. 910938 (pp. 933 ff.); R.J. Evans, 'Rome's Cimbric Wars (114-101 BC) and their impact on the Iberian Peninsula' Acta Classica 48 (2005), pp. 37-56 (p. 54).

46 C.F. Konrad, 'From the Gracchi to the First Civil War', in N. Rosenstein \& R. Morstein-Marx (eds.), A Companion to the Roman Republic (Oxford 2006), pp. 167-189.

47 For a complete record of these events see: F. Papazoglou, The Central Balkan, 294-314; L. Amela, 'Sexto Pompeyo, pp. 30-32; M. Zahariade, The Thracians, pp. 43-47.

48 Taking into account Mithridates vi's insistence in gathering all sorts of information on Pontus, it may be tempting to suggest that the Thracians and Scordisci could have been somehow informed of Rome's difficulties in the West during that same time period, although the truth is that we have no direct evidence to prove this. See, T. Naco, 'Roman and Pontic intelligence strategies. Politics and war in the time of Mithridates VI', War in History 21.4 (2014), pp. 401-423. 
which surely suffered a stressful time during the Thracian Wars. ${ }^{49}$ However, the real scope of the threat posed by the Thracian campaigns may be inferred from the regular dispatching of four consuls and several proconsuls to Macedonia as their provincia and Thrace as their actual military destiny. ${ }^{50}$ Whereas C. Porcius Cato's (cos. 114) was defeated while still in office and was found guilty of extortion upon safely arriving in Rome after his campaign, ${ }^{51} \mathrm{M}$. Minucius Rufus (cos. 110) remained in the region as a proconsul until 106, celebrating his triumph over Scordisteis et Thraecibus, according to the Fasti Triumphales (106), and also over the Besii and others. ${ }^{52}$ The core of the campaigns against the Thracians and other nomadic peoples from the North Balkans ended in 106, but it was never an easy victory for Rome and was certainly not a definitive one. For instance, in 104, Julius Obsequens briefly mentions the defeat of Thracians in Macedonia (Obs. 43). Then, T. Didius (cos. 98 in Nearer Spain) who was most likely a praetor in Macedonia in 101, possibly celebrated a triumph over Thracians or Scordisci after holding office in that province (Cic. Pis. 61$) .53$ Didius is also mentioned in the Lex de Provinciis Praetoriis, most often dated

49 F. Papazoglou, Les villes de Macédoine à l'époque romaine (Paris, 1988), pp. 368-371; G. Mitrev, 'Civitas Heracleotarum. Heracleia Sintica or the Ancient City at the Village of Rupite (Bulgaria)' Zeitschrift für Papyrologie und Epigraphik 145 (2003), pp. 263-272, (pp. 267 ff.).

$50 \quad$ C. Porcius Cato (cos. 114, Macedonia): defeated by Scordisci (Liv. Per. 63; Vel. 2.7.8-2.8.1; Flor. 1.39.1-5; Dio 26. Fr. 88; Amm. 27.4.4; Eutr. 4.24; Fest. Brev. 9.1); C. Caecilius Metellus Caprarius (cos. 113, Macedonia): campaigning in Thrace(Vell. 2.8.2; Eutr. 4.25; Fast.Triumph. (111); CIL I $\left.{ }^{2} .1,200,35\right) ;$ M. Livius Drusus (cos. 112 Macedonia, procos. 111 Macedonia): campaigning in Thrace against the Scordisci (Liv. Per. 63; Flor. 1.39.5; Fest. Brev. 9.2; Amm. 27.4.10; Dio 26. Frg. 88; Syll. ${ }^{3}$ 705, C 62-64; IG 7. 2413-2414; Fast.Triumph. (110); M. Minucius Rufus (cos. 110, Macedonia; procos. 109-106 Macedonia) actively campaigning in Thrace (Sal. Iug. 35.4; Liv. Per. 65; Vell. 2.8.3; Front. Strat. 2.4.3; Flor. 1.39.3-5; Amm. 27.4.10; Eutr. 4.27.5; Fest. Brev. 9.2; CIL I ${ }^{2}$, 2.692; Bull. Épigr. 1934, n. 230; Fasti Triumph. (106). See Th. Sarirakes, Romaioi Archontes Tai Eparkias Makedonias (Tessalonike 1971), pp. 55-63.

$5^{1}$ See n. 39. On the accusations: Vel. 2.81; Cic. 2.Verr. 4.24; Balb. 28. C. Cato was a moneyer in 123 BC according to M.H. Crawford, Roman Republican Coinage (Cambridge, 1974), n. 274.

$5^{2}$ For a discussion on literary and epigraphic sources for Minucius Rufus' campaigns, see: L. Amela, 'Sexto Pompeyo, pp. 31-32; M. Zahariade, The Thracians, p. 45; P. Delev, 'The burning of the temple, pp. 91-93.

53 See also: Flor. 1.39.5, Fest. 9; Iordan. 219. E. Drakopoulos, 'Titus Didius and his Macedonian Praetorship', Ancient World 21 (1990), pp. 123-126; M. Zahariade, The Thracians, p. 46. T. Didius, as a monneyer in 113, issued coins depicting gladiatorial combats between Galli who could easily be Scordisci prisoners: M.H. Crawford, Roman Republican Coinage, n. 294 (p. 308); J.-L. Desnier, 'Le gaulois dans l'imaginaire monétaire de la République. Images plurielles d'une réalité singulière', Mélanges de l'École Francaise de Rome 103.2 (1991), pp. 605-654 (pp. 625-626). 
at 100, just after his former operations in integrating the south-eastern part of Thrace ('Caenice' and 'Chersonese') into Macedonia the year before. ${ }^{54}$ For the next decade or so, the situation became equally unsettled. Roman policy regarding the Thracian tribes was based on bilateral surrendering treaties which were not always sufficient to maintain peace, especially with the new uprisings as mentioned in 97 (Obs. 48) and 92 (Liv. Per. 70; Obs. 53). ${ }^{55}$

Finally, a passage from Justin helps us to understand the complexity of the interstate politics and the military scenario existing on the verge of the First Mithridatic War. According to Justin, Mithridates sent legates to the Cimbrians, who had been recently defeated by Rome but whose experience in fighting the Romans would be quite useful, along with the Gallograeci, Sarmatae, Bastarnae and later, the Scythians, searching for military support in his foreseeable campaign against Rome (Just. $38.3 \cdot 6-7$ ) ${ }^{56}$ The Thracians are not mentioned in this passage, although in his book on the Mithridatic Wars, Appian refers several times to the fact that the Thracians fought in the Pontic armies simply as allies (summachoi)..$^{57}$ The most likely explanation for Justin's argumentum e silentio is that Mithridates already counted on Thracian mercenaries in his armies at that specific moment and there was no need to recruit more. ${ }^{58}$ Having said this, only the coin evidence has shed some light on Mostis, a Thracian king who most likely provided Mithridates with Thracian soldiers, although surprisingly, the classical literature remains silent on this remarkable figure..$^{59}$ Unlike

54 Cnidos Copy, Column Iv, ll. 5-30 and esp. 8-9: M.H. Crawford (ed.), Roman Statutes, vol. 1 (London, 1996), p. 241 and commentary p. 264; F.K. Drogula, 'The Lex Porcia and the Development of Legal Restraints on Roman Governors' Chiron 41 (2011), pp. 91-124 (pp. 115 ff.).

55 M. Zahariade, The Thracians, p. 47 wrongly places C. Sentius Saturninus' actions against Thracians in 97, when they occurred in 92.

56 Post haec Mithridates intellecto quantum bellum suscitaret, legatos ad Cimbros, alios ad Gallograecos et Sarmatas Bastarnasque auxilium petitum mittit. Nam omnes has gentes Romanum meditabundus bellum variis beneficiorum muneribus iam ante inlexerat. Ab Schythia quoque exercitum venire iubet omnemque Orientem adversus Romanos armat.

57 App. Mithr. 13; 15; 41; 57;69.

$5^{8}$ The 'barbarian' composition of Pontic armies is well known, as is the key role reserved to the Thracians in these armies. See recently J.-Ch. Couvenhes, 'Larmée de Mithridate VI Eupator d'après Plutarque, Vie de Lucullus, VI, 4-6', in H. Bru, F. Kirbihler, S. Lebreton (éds.), L'Asie Mineure dans l'Antiquité. Échanges, populations et territoires (Rennes, 2009), pp. 415-438 (p. 423).

59 Y. Youroukova, Coins of the Ancient Thracians, British Archaeological Reports, Suppl.Ser.4 (Oxford, 1976), pp. 38-39; a more sceptical view on such coins by F. de Callataÿ, L'histoire des guerres, pp. 256-258; D. Dana, 'Inscriptions', Companion to Ancient Thrace, pp. 243264 (p. 252); E.I. Paunov, 'Introduction to the Numismatics of Thrace, ca. 530 BCE-46 CE', Companion to Ancient Thrace, pp. 265-292 (pp. 275 ff.). 
Pontic armies, Roman legions first employed Thracian auxiliaries during the Mithridatic conflict, when the most powerful Thracian tribe, the Ordrysians, not only became a client kingdom of Rome's but also their most devoted military ally against Pontus. According to a well known inscription, the Thracian prince Sadalas sided with Sulla during the same military conflict, providing auxiliaries to support his legions. ${ }^{60}$ Regardless, the continuation of Thracian uprisings after the final outcome of the war against Mithridates for over a century clearly indicates that Rome never intended to replace the old Hellenistic kingdoms as a mercenary and auxiliary employer of the Thracian soldiers. After the Social War, the Italians who used to serve as auxiliaries in the Roman armies were finally accepted in the core of the legions as proper Roman citizens. Therefore, in order to achieve Rome's dominion over Thrace, a preliminary step became necessary, and that was the military disintegration of the Thracians who would eventually be integrated as auxiliaries into the Roman armies, but only upon their final conquest during the Roman Empire. ${ }^{61}$

\section{3}

\section{Conclusions}

The Roman dominions in Macedonia, Achaia and later, in Asia, were subject to continuous military pressure exercised by individuals belonging to peoples from beyond the Roman borders, since roughly the mid-second century. We have focused our analysis on two relevant case studies: Pontus and Thrace. Firstly, Mithridates' success in the Cimmerian Bosporus and Colchis as well as with his victories over the Scythians, Sarmatians and other populations from the Black Sea, never seemed to alter Rome's plans for the region. It is likely to believe that the extensive troubles in the West contributed to Rome's previous lax attitude towards the Pontic expansionism in the Black Sea, and perhaps even to its intervention in Anatolia, which was ultimately the main cause of the Mithridatic wars. After all, Pontus was never militarily integrated into the Imperium Romanum but was defeated in a long series of wars. Rome's definitive settlement of the lands from the Black Sea area was conducted from Macedonia and Asia much later, during the second half of the first century AD. Only then were the provinces of Thrace and Pontus created and Bosporus remained a

6o Caes. Civ. 3.4.3; Civ. 2Verr. 1.63, Luc. Civ. 5.54. M. Holleaux, 'Décret de Chéronée relatif à la première guerre de Mithridates', Revue des Études Grecques 32 (1919), pp. 320-337; M. Zahariade, The Thracians, p. 48; Delev, From Koroupedion, pp. 70, 72.

61 P. Delev, From Koroupedion, pp. 70-72; I. Lozanov, 'Roman Thrace', Companion to Ancient Thrace, pp. $75^{-90}$ (pp. $75^{-78}$ ). 
client kingdom of certain entity. Thus, the Pontic area constituted an extension of the Danubian limes which separated the Roman and Parthian Empires.

Secondly, the traditional role of the Thracians as mercenaries and auxiliaries enrolled in foreign armies faced a twofold problem during the last decades of the second century, having a major influence on their future integration in the Roman world. In the first place, the Thracian tribes experienced a progressive lack of employers when some of the Hellenistic powers and their armies began to lose their primary role in interstate politics and finally ceased to exist. Then, the general unrest in the Balkans provoked by the Cimbrian invasions also triggered new raids by Scordisci Gauls and other nomadic peoples towards the Roman province of Macedonia. Rome was therefore forced to intervene with obscure campaigns that have never been well explained because the historical evidence is quite limited. The Thracian realpolitik may be also observed just before and during the Mithridatic conflict, when both parties received their military support. Of course, it was too late for the Roman Republic to militarily integrate such people, as if Rome were another Hellenistic power. When the Thracians realized this, endless uprisings continued to occur for over almost two centuries until a province was eventually created in Thrace. 


\title{
Estranging the Familiar-Rome's Ambivalent Approach to Britain
}

\author{
Gil Gambash
}

On the eve of the Roman invasion of Britain, reports Dio, there arose a mutiny among the troops stationed in Gaul, on the banks of the Atlantic Ocean. The soldiers, we are told, were resentful at the thought of conducting a campaign 'outside the limits of the known world'. ' Whether or not that was the reason for the mutiny, or whether a mutiny took place at all, the fact remains that, to contemporary historians and, by implication, to their readers, there would have been nothing exceptional in perceiving Britain as lying outside the limits of the known world in the year $43 \mathrm{CE}$. Indeed, to the audience which regularly fed off imperial propaganda - whether in Rome or elsewhere in the empire-that same perception would not have seemed exceptional even later, since Claudius persisted throughout his reign in celebrating his British achievement as one won in unknown, primitive regions of the world. ${ }^{2}$ However, a substantial body of evidence speaks strongly for an intense direct relationship between Rome and Britain, the outset of which corresponds to Caesar's invasions of the island in 55 and 54 BCE. This article sets out this long-enduring Roman ambivalence regarding Britain, and ultimately aims to explain a whole century of atypical imperial inaction.

The suggestion that Caesar's two campaigns on the island left no enduring impression on the relationship between Rome and Britain was made by Strabo,

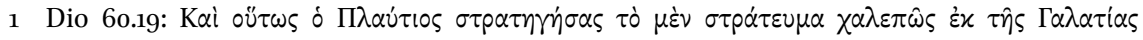

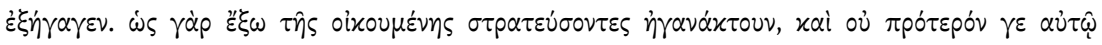
$\dot{\varepsilon} \pi \varepsilon i \sigma \theta \eta \sigma \alpha \nu .$. ['Thus it came about that Plautius undertook this campaign, but he found it difficult to lead his army outside of Gaul. For the soldiers were vexed by the thought of carrying on a campaign outside the known world, and would not be prevailed upon...']. Unless stated otherwise, translations are supplied by the author of the article.

2 In 49, for example, the pomerium of the city of Rome was extended on the grounds of Claudius' conquests 'beyond Ocean'. See Tac. Ann. 12.23-4; ILS 212-13; G. Gambash, 'Official Roman Responses to Indigenous Resistance Movements: Aspects of Commemoration', in H. Cotton, J. Geiger, and G. Stiebel (eds.), Israel's Land: Collected Papers (Tel Aviv/Jerusalem 2009), 54-56. 
and then again, about a century later, by Tacitus. ${ }^{3}$ Each of them probably had reasons of his own for making the claim: Strabo maybe supporting a line opposed to the invasion; Tacitus wishing to aggrandize later campaigns. ${ }^{4}$ But Caesar's achievement, in fact, is likely to have been both significant and enduring. The technical and legal terms - such as deditio (capitulation) and vectigal (impost) - employed by him in his report on the conditions of surrender of the Britons, imply that a British province was possibly in the first stages of being formed. ${ }^{5}$ To be sure, treaties had been drawn up, hostages taken, and the tribute that was imposed was in all likelihood paid. There is no reason to doubt that these agreements lasted at least until political changes in Britain had taken place, well into Augustus' reign. For those emperors who sought it, Caesar had made available 'legitimate' claim over Britain.

Regarding Augustus and Tiberius, Tacitus says: 'and even when there was peace [i.e. from civil war], there was a long oblivion of Britain. Augustus called it policy (consilium), Tiberius - a received precept (praeceptum). ${ }^{6}$ It may be understood from this statement that the first two emperors did not want to invade Britain. Yet Tacitus' zeal for the acquisition of Britain is given away all too clearly throughout the Agricola, where he parades the exploits of his father-in-law on the northern parts of the island, and reproves all previous governors of the province who failed to pursue expansion before him. ${ }^{7}$ At least with regard to Augustus, it has to be assumed that Tacitus in fact criticizes the reality after the death of the princeps, rather than his actual intents during his lifetime. Literary evidence suggests that Augustus may very well have been on his way to invade Britain more than once.

Dio mentions three instances, in the early $20 \mathrm{BC}$ B, when Octavian/Augustus initiated a campaign against Britain. ${ }^{8}$ In the first attempt, interrupted by unrest in Dalmatia, Octavian is said to have wanted to emulate his father. Diplomacy was ultimately preferred in the later attempts. Of course, Augustus' expansionist ambitions and familiarity with Gaul would have made the consideration of

3 Strabo 4.5.3; Tac. Agr. 13: 'So, first of all the Romans, the divine Julius invaded Britain with an army. Although he scared the inhabitants with successful fighting and gained control over the coast, he can be seen to have revealed the island to posterity, not to have delivered it to them.'

4 See more below on both authors and their biases.

5 S.S. Frere, Britannia: a History of Roman Britain (London/ New York 1978), 27; D. Braund, Rome and the Friendly King: the Character of the Client Kingship (London/ New York 1984), 64.

6 Tac. Agr. 13.

7 G. Gambash, 'To Rule a Ferocious Province: Roman Policy and the Boudican Revolt', Britannia 43 (2012), 1-15.

8 Dio $49.38 .2 ; 53.22 .5 ; 53.25 .2$. 
invading Britain viable. It should also be noted that the Augustan poets appear to have conducted a complex dialogue with the idea of imperial expansion and the implications of its possible discontinuation. It is noteworthy that Britain and the prospects of its conquest are often used in these works to epitomize potential Augustan expansion. ${ }^{9}$

More importantly, in his Res Gestae Augustus mentions approaches made to him by kings from Britain, Dumnobellaunus and Tincommius. ${ }^{10}$ As was the case with preparations for most other Roman invasions of Britain-from Caesar to Claudius - contacts with indigenous kings would have played a significant role in the intensification of Roman involvement in local politics. ${ }^{11}$ From the second century вСЕ onwards, such contacts were a key feature across the Mediterranean in those cases of Roman foreign diplomacy that ended with occupation.

It is true, of course, that embassies from all over the empire, as well as from beyond its frontiers, came to Rome to be heard by the Senate, and later also by the emperor. But it would be far too simplistic to assume that all such diplomatic visits shared in aim and were alike in nature. The interests of the visitors would have varied greatly in accordance with their relationship to Rome; and the specific destination of their visit- the emperor, the Senate, the Capitol, and so on -would have been dictated by their particular needs. The Res Gestae itself supplies a useful distinction between embassies from remote regions, whose sole aim was to obtain Rome's amicitia, and visits of kings from closer places, arguably already within Roman hegemony, who came as suppliants to seek refuge. ${ }^{12}$ An Indian prince would not have fled to Augustus had he been

Hor. Odes 1.35.29-30;3.5.1-4; 4.14.45-8; Epodes 7.7-8. Tibullus 3.7.148-50. Ovid (Met.15.752) goes as far as to proclaim that Augustus 'conquered the Britons, surrounded by the sea'. See also Virg. Ecl. 1.66: 'The Britons, wholly isolated from the entire world' (with Servius commenting: '[Britain] is an island set in the northern Ocean, and poets call it "another world”'). See J. Arieti, 'Horatian Philosophy and the Regulus Ode (Odes 3.5)', TAPA 120 (1990), 209-220.

$10 \quad R G$ 32. See also P. Salway, Roman Britain (Oxford 1981), 47.

11 For Caesar see $B G$ 4.21; 5.20. For Gaius see Suet. Cal. 44. For Claudius see Dio 60.19.

12 RG 31: Ad me ex India regum legationes saepe missae sunt non visae ante id tempus apud quemquam Romanorum ducem. Nostram amicitiam appetiverunt per legatos Bastarnae Scythaeque et Sarmatarum qui sunt citra flumen Tanaim et ultra reges, Albanorumque rex et Hiberorum et Medorum ['Embassies were often sent to me from the kings of India, a thing that had not happened until that time to any other Roman leader. Ambassadors came to seek our friendship from the Bastarnae and Scythians, and from the kings of the Sarmatians who live on either side of the river Tanais, and from the king of the Albani and of the Hiberi and of the Medes']. Cf. $R G$ 32: Ad me supplices confugerunt 
driven away from his kingdom. British kings came to see the princeps also for pragmatic needs. A similar pattern may be seen in the visits to Rome of Gallic embassies, and in treaties that were made with Gallic tribes long before the conquest of Gaul, all symptomatic of Rome's increasing control over the region. ${ }^{13}$

The presence of a friendly king in a frontier region would perforce have indicated Roman interests in that region. Visits of kings to Rome should therefore be particularly noted, since they signified an important step in the development of the relationship. ${ }^{14}$ Since the passage in the Res Gestae relevant to Britain appears to relate to foreign kings who sought refuge in Rome, it is plausible that there was urgency in the implication of Rome in British local affairs.

One indication that Augustus indeed responded to the approaches of British kings by involving Rome in the political issues of Britain comes from coins. The use of coinage accompanied local processes of centralization in political power witnessed in Britain during the first century BCE. The initial emergence of Romanized coin-types in Britain in the 20s BCE may be related to the Romanization of Gallic coinage. ${ }^{15}$

But, against this background of common influence over Britain of developments in Gaul, stands out the dramatic change in coinage design which was witnessed in southeastern Britain around 15 BCE. At this time, the coinage of Tincommius suddenly changed, to resemble Roman coin-types closely. The quality of the coins is so high that it encourages modern scholars to think that the dies must have been the work of Roman engravers. Three pairs of dies have been identified through Tincommius' coinage, and their presence in Britain strongly suggests that the king had entered one form or another of a treatyrelationship with Rome, probably around 16 BCE. ${ }^{16}$ The fact that the Res Gestae relates to Tincommius later as a refugee and suppliant in Rome supports the idea, as does the fact that later kings of his line had the title REX inscribed on

reges Parthorum Tiridates et postea Phrates regis Phratis filius. Medorum Artavasdes, Adiabenorum Artaxares, Britannorum Dumnobellaunus et Tincommius, Sugambrorum Maelo, Marcomanorum Sueborum ... rus ['The kings of the Parthians, Tiridates and then Phrates, the son of king Phrates, fled to me as suppliants. Of the Medes Artavasdes, of the Adiabeni Artaxerxes, of the Britons Dumnobellaunus and Tincommius, of the Sugambri Maelo, of the Marcomanni and Suevi... rus'].

13 G. Woolf, Becoming Roman: the Origins of Provincial Civilization in Gaul (Cambridge 1998), $36-37$.

14 Braund 1984, op. cit. (n. 5), 55-8; $165^{-7}$.

15 The Atrebates/Regni; the Catuvellauni/Trinovantes; and Kent. See D. Nash, Settlement and coinage in Central Gaul c. 200-50 BC (Oxford 1978).

16 D. Nash, Coinage in the Celtic World (Oxford 1987), 128-130. Frere 1978, op. cit. (n. 5), 29-30. 
their coins-not a British title, but rather one that would have been assumed along with recognition from Rome.

It is noteworthy that Strabo's brief survey of the island indicates that the geographer did not think Britain worthy of invasion. ${ }^{17}$ Local agriculture and patterns of settlement - two key criteria by which the Geography measures the degree of development of the civilizations surveyed by it-are evaluated as backward. The revenue that would be collected is estimated to be equal to the cost of a garrison of 'one legion and some cavalry' - the force needed, in Strabo's eyes, to secure the payment of taxes from the corresponding region. It has been suggested that this passage could have been polemical; it has at least to be noted that it represents a point of view opposite to the one taken by the Augustan poets, and that it may have been, on the other hand, agreeable to Tiberian reluctance to expand the empire further, in accord with Augustus' said consilium. ${ }^{18}$

That is not to say, however, that Tiberius did not maintain Rome's relationships with British kings. Such activity would have been in accord with Tiberian diplomatic efforts elsewhere to enhance and fortify the sphere of client relationships. ${ }^{19}$ Hints of such ties may be found in the coins of Verica, king of the British Atrebates, and of Cunobelinus, king of the Catuvellauni, which have been recognized as bearing resemblance in the portrait on their obverse to the head of the emperor. ${ }^{20}$ If a replication of the imperial head was indeed intended, it may be suggestive of an involvement of Tiberius in British affairs, possibly even to the point of accepting local allegiances. ${ }^{21}$

Beyond coinage, there is abundant evidence of intensification in Roman trade contacts with southeast Britain. The emergence in Britain of Roman and continental goods such as wine, pottery, glass, and metalwork would have helped to increase the differentiation between tribal elites and lower classes. Roman burial artifacts retrieved from iron-age tombs should be seen as part of the same phenomenon. According to the widely accepted hypothesis, members of the British elite monopolized imported Roman goods and controlled their

17 Strab. 2.5.8: 'For although they could have held Britain, the Romans disdained to do so, because they realized that there was no reason to fear the Britons- they are not powerful enough to attack us - and that they would gain nothing by occupying their country'.

18 D. Braund, Ruling Roman Britain: Kings, Queens, Governors and Emperors from Julius Caesar to Agricola (New York 1996), 80-89.

19 For example, beyond the Rhine, in the region from lower Germany to the middle Danube; see E.N. Luttwak, The Grand Strategy of the Roman Empire from the First Century A.D. to the Third (Baltimore 1976), 21.

20 For Verica see R.D. Van Arsdell, Celtic Coinage of Britain (London 1989), 170, 533-1; 172, 551-1. For Cunobelinus see ibid. 421, 2089-1.

21 M. Crawford, Coinage and Money under the Roman Republic (London 1985), 273-5. 
distribution, in order to enhance their local prestige, and, thus, their control over society. ${ }^{22}$

Furthermore, Strabo actually saw Britons in Rome, and could base his description of their appearance on these encounters. ${ }^{23}$ These Britons could have been anything from imported slaves to those British kings who were said by Strabo, as well as by Augustus' Res Gestae, to have come to see the princeps as supplicants. ${ }^{24}$ In fact, Strabo's testimony to British kings making offerings on the Capitol should be highlighted, especially coming as it does from an original source and a likely eyewitness:

At the present, however, some of the chieftains there obtained the friendship of Caesar Augustus by their embassies and solicitations, and have not only dedicated offerings in the Capitol, but have also managed to make the whole of the island virtually Roman property ( $x \alpha i$ oix $\varepsilon i \alpha \nu ~ \sigma \chi \varepsilon \delta \delta o v$

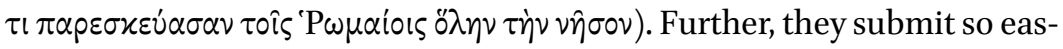
ily to heavy duties $[. .$.$] that there is no need of garrisoning the island.$

The privilege of offering such dedications would have been granted to kings with the status of clients, whereas the circumstances of the dedication could have been the very act of the formal Roman recognition of these kings as rulers. ${ }^{25}$ Since the time of the republic, foreign rulers had offered their acceptance of Roman hegemony through sacrifices and dedications made on the Capitol, and copies of treaties would have been kept there too. ${ }^{26}$

22 C.C. Haselgrove, 'Wealth, Prestige and Power: the Dynamics of Late Iron Age Political Centralization in South East England,' in C. Renfrew and S. Shennan (eds.), Ranking, Resource, and Exchange (Cambridge 1982), 79-88; C.C. Haselgrove, 'Romanization before the Conquest: Gaulish Precedents and British Consequences,' in T.F.C. Blagg and A.C. King (eds.), Military and Civilian in Roman Britain (Oxford 1984), 1-64; M. Millett, The Romanization of Britain. An Essay in Archaeological Interpretation (Cambridge 1990), 35-9; D.J. Mattingly, An Imperial Possession: Britain in the Roman Empire, 54 BC-AD 409 (London/ New York 2006), 84.

23 Strabo 4.5.2: 'I myself saw in Rome young men towering as much as half a foot above the tallest people in the city, although they were bandy-legged and their figure presented no attractive lines otherwise'.

24 Strabo $4 \cdot 5 \cdot 3$.

25 For the significance and circumstances of dedications made on the Capitol by client kings and communities see C. Reusser, Der Fidestempel auf dem Kapitol in Rom und seine Ausstattung (Rome 1993); Braund 1996, op. cit. (n. 18), 85.

26 F. Millar, Rome, the Greek world, and the East: vol. 2: Government, Society, and Culture in the Roman Empire (Chapel Hill, NC 2004), 200; R. Mellor, 'The Dedications on the Capitoline Hill', Chiron 8 (1978), 319-330. 
Now, Gaius Caligula's intentions with regard to Britain are seldom taken seriously. The hostile literary sources — Suetonius and Dio — are not greatly helpful in clarifying the emperor's designs in relation both to Britain and to Germany. ${ }^{27}$ At least regarding the bridge of boats built in $39 \mathrm{CE}$ across the northern part of the bay of Naples, between Baiae and Puteoli, Suetonius knew of two seemingly rational prevailing interpretations for the arrangement of the spectacle: some thought that it was done in imitation of Xerxes' bridging of the Hellespont, others, that it was meant to inspire fear in Germany and Britain. ${ }^{28}$

The fact that a campaign indeed followed in the regions of the Rhine and the British channel does lend force to these explanations. And, despite Suetonius' scorn of the event, we should pay heed to another British leader, Adminius son of Cunobelinus, who escaped from Britain to Gaius, an act paraded in Rome 'as if the entire island submitted to him.'

Seen against this backdrop of a tightening relationship between Rome and southern Britain, it is a remarkable fact that, throughout the century that elapsed between the invasions of Caesar and Claudius, the role of Britain remained constant in Roman cosmology — as a distant, primitive place, located beyond the boundaries of the inhabited world. Indeed, to begin at the very end, even conquest itself did not introduce too rapid a change to this representation, and, as the southern part of the island was moving towards standardized forms of provincialization, familiar to the historian from the provincial world in its entirety, estranging descriptions such as that of Pomponius Mela could still be written: ${ }^{29}$

The nature of Britain and its inhabitants should soon be described more clearly and on the basis of greater exploration. For, after it has been closed for so long, the greatest emperor is opening it up, the conqueror of peoples not only yet untamed, but also completely unknown. Just as he is pursuing the truth of facts themselves in war, so he is bringing it back to be presented in his triumph.

27 Suet. Cal. 44 \& 46. Dio 59.25. For the event and its interpretations, see S.J.V. Malloch, 'Gaius on the Channel Coast', cQ 51.2 (2001), 551-556.

28 Suet. Cal. 19: 'I know that many people thought that Gaius devised such a bridge in emulation of Xerxes, who drew considerable admiration by bridging the narrower Hellespont; others thought that it was to inspire fear in Germany and Britain — which he planned to invade — by the rumor of some stupendous project'. 
Such statements, it must be emphasized, did not just strive to present the achievement of the emperor in a flattering light, regardless of the actual situation in the field. They rather fell in line with a long series of similar previous representations, which had gradually grown more dissonant with the dynamic reality.

The main reason for this growing dissonance appears to lie in the strong emphasis that was usually put on Ocean as the boundary of the inhabited world, and, by implication, on Britain as a place beyond that boundary. While this cosmology regularly played a symbolic part in the daily routine of imperial propaganda, it could have had distinctly tangible implications when the actual boundary-line of the empire had to be negotiated, in this case for the purpose of its extension to include Britain. It was a world-order inherited from similar Greek ideas, though it was probably Alexander's empire above all that accentuated the physical role of Ocean as the endpoint to all expansionist ambitions. ${ }^{30}$

The notion of mare nostrum is essential here, and, since modern interpretations of it are often misguided, it deserves some attention. The problem usually lies in drawing too direct lines between the occurrence of the term and an alleged Roman perception of political ownership over the Mediterranean. Such a reading of mare nostrum would typically go hand in hand with simplistic descriptions of Roman imperialism, recognizing the early Punic wars - particularly the second one - as the origin of Roman aspirations in the Mediterranean; and the conquests of the late republic, culminating with Augustus and the annexation of Egypt, as realizing these aspirations in a gradual process of expansion, concluding with the obtainment of control over the sea in its entirety. ${ }^{31}$ More nuanced interpretations go as far as to suggest that

$30 \quad$ See, for example, Diod. Sic. 17.104; Justin, Epitome 12.10.6.

31 Examples are ubiquitous, and come from various perspectives on the Mediterranean; below I borrow a couple of useful definitions for such perspectives from: P. Horden, 'Mediterranean Excuses: Historical Writing on the Mediterranean Since Braudel,' History and Anthropology vol. 16/1 (2005), 25-30. To Matvejević (dubbed by Horden the 'rhapsode'), the Romans employed the term merely because the sea 'belonged' to them: P. Matvejević, Mediterranean: a Cultural Landscape (trans. M.H. Heim, Berkeley 1999), 142-143. And Abulafia (a 'reductivist', according to Horden) dedicates a traditional chapter to 'our sea', highlighting Roman political and economic ambitions, culminating under Augustus in a 'single rule over mare nostrum': D. Abulafia, The Great Sea (Oxford 2011), 191-203. The same notion pervades discussions which adopt a wider scope, observing longue durée processes in the Mediterranean: Rome's objective was thus 'to defeat all Mediterranean rivals, until the sea became mare nostrum', as puts it S.C. Calleya, 'Bridging History and Future Security Policy', in J.B. Hattendorf (ed.), Naval Policy and Strategy in the Mediterranean (London 2000). 
the title-and, by implication, the imperialistic agenda which it must have represented-were conceived teleologically, with Roman thinkers and politicians narrating past motivations in light of present achievements. ${ }^{32}$

When examined in context, however, the employment of mare nostrum by Roman writers, especially in its early occurrences, does not reveal itself to be connotative of political power and empire. Instead, it is employed mostly in order to supply geographical distinction and a means to differentiate between the sea in 'our side of the world' and other regions of the known world-be it the Atlantic Ocean on the West; the Mesopotamian empires on the East; or, more specifically, the further, land-locked end of Mediterranean provinces, such as Africa. ${ }^{33}$ Pomponius Mela himself, quoted above as the very example of partisanship for Claudian imperialism beyond the Mediterranean realm, merely defines the term mare nostrum as the Mediterranean's proper name, and continues to use it as such on more than a dozen occasions in his Description of the World. ${ }^{34}$ If these descriptions go beyond using the term mare nostrum as a mere geographical name, it is only to connote a sense of a sea shared by the sum of all societies residing on its shores and islands. ${ }^{35}$

The mare nostrum that emerges from these descriptions is recognizable from the Greek usage of that self same term, and close derivatives thereof. From Hecataeus of Miletus onward, the Mediterranean had been described by Greek thinkers as anything from 'our sea' to 'the sea next to us', or 'the sea in our part of the world' ${ }^{36}$ Of course, even when Thucydides and others refer to the Mediterranean as a 'Hellenic sea', they refer to a phenomenon which is cultural far more than it is political. ${ }^{37}$ When they write about 'their sea', therefore,

32 E.g. H. Beck, 'The Second Punic War: The Reasons for the War', in D. Hoyos (ed.), A Companion to the Punic Wars (Malden, MA 2011).

33 Thus Livy's descriptions of the western parts of the Mediterranean, bordering with Ocean (e.g. Liv. 26.42; 28.1; 41.1); Sallust's geographical setting for the Jugurthine War (Sal.Jug. 17); and Caesar's practical insights regarding differences between sailing the Ocean and 'our sea' (Caes. $B G$. 5.1). The same applies to later writers, already living alongside a politically unified Mediterranean, certainly Pliny the Elder, who makes abundant usage of the term (e.g. Plin. $N H$ 6.32; 6.35; 12.32; 13.48).

34 Pomp. Mel. 1.7; then passim.

35 Livy's mare nostrum is just as Carthaginian as it is Roman (Liv. 26.42; 28.1). The Mediterranean appears on a good number of occasions as the home of a variety of peoples and cultures: Sal. Jug. 18; Pomp. Mel. passim; Plin. $N H$ passim.

36 Hecataeus F302c: $\dot{\eta} \dot{\eta} \mu \varepsilon \dot{\tau} \tau \rho \alpha \theta \dot{\lambda} \lambda \alpha \sigma \sigma \alpha$; Hecataeus F18b: $\dot{\eta} x \dot{\alpha} \theta^{\prime} \dot{\eta} \mu \alpha \dot{\alpha} \varsigma \dot{\alpha}^{\lambda} \alpha \sigma \sigma \alpha \alpha$; Plato, Phaedo 11за: $\pi \alpha \rho$ ' $\dot{\eta} \mu$ iv $\theta \dot{\alpha} \lambda \alpha \sigma \sigma \alpha$; Herodotus prefers 'this sea' (Hdt. 1.185; 4.39; 4.41: $\dot{\alpha} \pi \dot{\partial} \tau \hat{\eta} \sigma \delta \varepsilon \tau \hat{\eta} \varsigma$ $\theta \alpha \lambda \dot{\alpha} \sigma \sigma \eta \varsigma)$.

37 Thuc. 1.4. 
also the Roman writers should be seen as imagining themselves more as part of Plato's congregation of frogs than as the masters of the Mediterranean. ${ }^{38}$ When the time comes, it is leaving the familiarity of this pond that proves most difficult.

Caesar was ever mindful of the otherworldliness of Britain, even as his approach remained practical, allegedly sailing to Britain to eliminate threats he recognized there to his achievements in Gaul, and dealing with the vicissitudes inflicted on him by the unfamiliar Ocean in a straightforward manner-for example by learning to anchor his ships at a greater distance from one another on account of the higher Atlantic tides. Indeed, this approach is characteristic of the Roman general in the field, somewhere on the outskirts of the known world, venturing to cross into the unfamiliar, usually for the declared purpose of reconnaissance - and for the unhidden desire for private glory. The list of such ventures is long and distinguished enough, and includes C. Cornelius Gallus' campaign in the Sudan in $29 \mathrm{BCE}$; L. Cornelius Balbus' expedition to the land of the Garamantes in 19 вСЕ; and C. Suetonius Paullinus' crossing of the Atlas mountains in $41 \mathrm{CE}$. To be sure, these daring reaches beyond the cosmological conventions regularly concluded in retreat, and, beyond introducing novelties to Roman awareness, they had little actual effect on Roman expansion.

Despite Caesar's significant contribution to the Roman world's familiarity with Ocean and Britain, the sea continued to be represented as the natural boundary line of the empire, and the island - as the very contrast of Roman civilization. The tension between this dichotomic representation and the growing familiarity portrayed above may be seen in all its clarity during the Augustan period, when the administration's contacts with Britain were left out of the Roman cosmology as it was represented in such documents as Strabo's Geography and the Res Gestae; ${ }^{39}$ and when those same poets who imagined Augustus invading Britain continued to regard the island as a place completely detached from their own world. ${ }^{40}$

38 Plato, Phaedo 109 a-b: 'I believe that the earth is immense and that those of us located between the pillars of Heracles and the river Phasis (Rioni) live in a small part of it around the sea, like ants or frogs around a pond, and that many other people live in many other such places.'

Strab. 2.5.5: 'In one of these quadrilaterals (it is of no consequence in which one) we say that our inhabited world is situated, surrounded by the sea and like an island'; $R G$ 26.1-2: 'I extended the boundaries of all the provinces which were bordered by races not yet subject to our empire. The provinces of the Gauls, the Spains, and Germany, bounded by the Ocean from Gades to the mouth of the Elbe, I reduced to a state of peace'. 
If doubts regarding the role of Ocean in Roman cosmology began to infiltrate during the Augustan period, they disappeared quickly as a result of a catastrophic expedition along the coasts of the Northern Sea early during the reign of Tiberius. The campaign of Germanicus in the year 16 is an episode little-heeded by modern day scholarship, yet it is transmitted by the sources as a significant event, traumatic not only to the commander and his troops, but also to Roman society more generally. The ambitious endeavor saw a fleet of one thousand ships launched from the region of the lower Rhine, down that river, and into the Wadden Sea. The fleet then sailed an estimated distance of $150 \mathrm{~km}$ in the Ocean itself, to the point of the outlet of the Ems, where it turned to sail up that river, towards the disembarkation of the troops and the landcampaign that followed against the Cherusci.

It was the way back, taken along the same route, that saw this gigantic army encounter Ocean's wrath, in a storm that scattered the fleet as far as Britain, and destroyed a significant part of it. Tacitus tells us that 'not a man returned from the distance without his tale of marvels - furious whirlwinds, unheardof birds, and enigmatic shapes half-human and half-bestial.'41 A still more vivid testimony comes from the contemporary Albinovanus Pedo, a poet and a soldier in Germanicus' army, who was in all likelihood an eyewitness to the disaster:42

Where are we being carried? Day itself is in flight, furthest nature shuts off in everlasting shadows the world we have left. Are we looking for races beyond, in another clime, a new world untouched by breezes? The Gods call us back, forbid us to know the end of creation with mortal eyes. Why do our oars violate seas that are not ours, waters that are holy? Why do we disturb the quiet home of the Gods?

The lines may be poetic, but their tones are shared by the practical elaboration of another contemporary-Seneca the elder-who chose this timing to dedicate his first suasoria to the topic: 'Alexander considers whether he should sail the Ocean. ${ }^{43}$ The declamatory narration, rhetorical in nature, gives a wide

\footnotetext{
41 Tac. Ann. 2.24 .

42 Albinovanus Pedo (ap. Seneca Suas. 1.16-23), here in the translation (and see also the useful commentary) of M. Von Albrecht, Roman Epic (Leiden 1999), 209-215.

43 Seneca Suas. 1: 'Nature gave limits to everything to which she gave magnitude: nothing is infinite other than Ocean! [...] Here lies the motionless sea, an indolent, shapeless mass of nature, isolated within its own boundaries. This deep great void nourishes terrible, unknown shapes, and great monstrosities; the light is mixed with dense mists; the
} 
stage to the traditional perception of Ocean, falling in line with the familiar cosmology of the age, and easily imaginable as complementary of Strabo's practical arguments against crossing to Britain.

It is this mindset of Albinovanus Pedo, his fellow soldiers, and the Roman public more generally, that we should keep in mind as we turn, finally, to consider once more Gaius Caligula. The variety and nature of his unique maritime undertakings may receive a rational interpretation when aligned with this atmosphere of general apprehension regarding Ocean. Other than the bridge of boats in the bay of Naples we have to consider the much ridiculed event of the battle-line drawn by Gaius against the shores of Ocean, and the collection by the troops of sea-shells as booty: ${ }^{44}$

Finally, as if he intended to bring the war to an end, he drew up a line of battle on the shore of the Ocean, arranging his ballistas and other artillery; and when no one knew or could imagine what he was going to do, he suddenly bade them gather shells and fill their helmets and the folds of their gowns, calling them 'spoils from the Ocean, due to the Capitol and Palatine.'

The episode has been interpreted as describing a mutiny of the troops and the ridiculing punishment conceived by the emperor in return for their cowardice. ${ }^{45}$ A mutiny, as we shall see, may well have broken out. But Gaius' actions here may be interpreted more plausibly as aiming to produce a symbolic subjugation of the Sea, that comes as a prelude to crossing it. And the symbolism of this act was in effect supplemented by the measure-at once symbolic and practical—of building a lighthouse on the spot which would have been envisioned as the port of departure for the invasion, and the future link of the invading forces with the mainland they leave behind. ${ }^{46}$

Such an approach should also encompass the ship that was built to bring the Vatican obelisk from Egypt, and was later sunk by Claudius at the entry to the harbor of Portus, forming the base for the artificial island on which the

day is carried off by darkness; the heavy water lies fixed; and there are no stars, or they are unknown. This is, Alexander, the nature of things: beyond everything there lies the Ocean, beyond the Ocean-nothing.'

44 Suet. Cal. 46; Dio 59.26.

45 A. Winterling, Caligula: A Biography (Berkeley 2011).

46 See Braund 1996, op. cit. (n. 18), 91-5. 
famous lighthouse was mounted. ${ }^{47}$ Other innovative vessels-Liburnian galleys with ten banks of oars-are reported by Suetonius, who obviously focuses on their fanciful luxuriousness. ${ }^{48}$ And the list of enterprises of maritime nature does not end here: the reference to seawalls (moles) built into the open sea may well refer to the construction of harbors, based on the experience accumulated in Herodian Caesarea Maritima, and anticipating - or maybe even initiating - the building of Portus itself. ${ }^{49}$ To be sure, the two gigantic ships built in Lake Nemi have so far been considered in context with the emperor's notorious profligacy. ${ }^{50}$ The archaeology of the ships demonstrates state-of-theart technology, and notable innovations in naval technology, manifested, for example, in the anchors and the water-pumps. ${ }^{51}$ The fact that the ships were probably deliberately sunk in the lake shortly upon Gaius' assassination suggests common public knowledge of them. ${ }^{52}$

In light of the discussion presented here, it may very well be that Gaiuswho personally did not particularly like the sea and did not know how to swim-had far more practical intentions behind these projects than previously imagined. ${ }^{53}$ Conceivably, he was guided by aspects of public opinion and the mental preparation of the army towards a major reach beyond the cosmological convention of mare nostrum - namely, the invasion of Britain. By portraying himself as a leader capable of mastering the sea, he was not so much aiming to intimidate his intended enemies beyond Ocean, but rather to instill confidence in the hearts of his own people, in effect foreseeing the mutiny that was bound to arise at the eve of the Channel crossing.

47 See Plin. $N H$ 16.201. The report on the ship's connection to Portus is supplied by Suetonius (Suet. Claud. 20).

48 Suet. Cal. 37: 'He also built Liburnian galleys with ten banks of oars, their sterns studded with gems, their sails multicolored, with great baths, colonnades, and banquet-halls, and even a great variety of vines and fruit trees; so that he might travel along the shores of Campania amid songs and choruses, reclining at table from an early hour'.

49 Suet. Cal. 37.3: Et iactae itaque moles infesto ac profundo mari...

$50 \quad$ R. Lanciani, 'The Mysterious Wreck of Nemi', The North American Review 162.471 (1896), 225-234; R. Lanciani, New Tales of Old Rome (New York 1902), 212; J.F. Gummere, 'The Ships in Lake Nemi', The Classical Weekly 22.13 (1929), 97-98; G. Ucelli, Le Navi di Nemi (Rome 1950).

$5^{1}$ P.A. Gianfrotta, 'Ancore "romane". Nuovi Materiali per lo studio dei traffici marittimi', Memoirs of the American Academy in Rome 36 (1980), 103-116.

$5^{2}$ Ucelli 1950, op. cit. (n. 50), 85-97.

53 Suet. Cal. 54 . 


\title{
Rome and Persia in the Middle of the Third Century AD (230-266)
}

\author{
Lukas de Blois
}

From about 230 to $266 \mathrm{AD}$ a momentous struggle was going on at the eastern borders of the Roman Empire. The Persian wars waged by Severus Alexander (231-234), Gordian III (242-244), and the emperors and vassal kings who reigned between $25^{2}$ and 268 should be counted among the main causes of the problems Roman emperors had to face in the middle decades of the third century. The issues I want to discuss in this contribution are: why did this long and dangerous conflict arise, what was the character and aim of Persian actions, and what was the impact of these Persian wars on Roman imperial power?

In 8o.3.1-4 Cassius Dio, writing about Severus Alexander's later years, tells us:

The situation in Mesopotamia became still more alarming and inspired a more genuine fear in all, not merely the people in Rome, but the rest of mankind as well. For Artaxerxes (i.e. Ardashir I, AD 226-241), a Persian, after conquering the Parthians in three battles and killing their king, Artabanus, made a campaign against Hatra, in the endeavour to capture it as a base for attacking the Romans. He actually did make a breach in the wall, but when he lost a good many soldiers through an embuscade, he moved against Media. Of this country, as also of Parthia, he acquired no small portion, partly by force and partly by intimidation, and then marched against Armenia. Here he suffered a reverse at the hands of the natives, some Medes, and the sons of Artabanus, and either fled, as some say, or, as others assert, retired to prepare a larger expedition. He accordingly became a source of fear to us; for he was encamped with a large army so as to threaten not only Mesopotamia but also Syria, and he boasted that he would win back everything that the ancient Persians had once held, as far as the Greek Sea, claiming that all this was his rightful inheritance from his forefathers. The danger lies not in the fact that he seems to be of any particular consequence in himself, but rather in the 
fact that our armies are in such a state that some of the troops are actually joining him and others are refusing to defend themselves. ${ }^{1}$

This is no report from hindsight, by a later author who knew what Persian wars could be like. It is, rather, a chapter written by a contemporary senator, who was well acquainted with the emperor Severus Alexander. ${ }^{2}$ In this passage there are two important interconnected issues: Ardashir and his growing army are a source of fear to Rome as soon as they come near Syria and Mesopotamia, and Ardashir wants to reconquer parts of the Roman Empire that had once belonged to the Achaemenid Empire. ${ }^{3}$ Apparently, Dio's perception of the rising conflict is that Persia was the agressor. At the end of this passage Dio adds that the Persians were of no great consequence in themselves, but had a good chance to win because the quality of the Roman army of the East was very poor, which fits neatly with Dio's negative attitude towards the Roman soldiery, but also testifies to his underestimating of quantity and quality of the forces the Sassanians could mobilize. ${ }^{4}$

Another contemporary author, Herodian, tells us in 6.2.1:

... in his (i.e. Alexander's) tenth year unexpected letters came from the governors of Syria and Mesopotamia with information that Artaxerxes (i.e. Ardashir), king of the Persians, had defeated the Parthians, broken up their eastern kingdom and killed Artabanus, the previous great king who wore the double crown. He had also gained complete control over the neighbouring barbarians and reduced them to tributary status. He was causing unrest by refusing to be contained by the river Tigris and was crossing the banks which were the boundary of the Roman empire. Mesopotamia was overrun and Syria threatened.

1 Cassius Dio 80. 3-4. Translations of passages in the works of Cassius Dio and Herodian were borrowed from editions in the Loeb Classical Library.

2 See Cassius Dio 80. 5. 1: Severus Alexander honored Dio in various ways, especially by appointing him to be consul for the second time, as his colleague, and taking upon himself personally the responsibility of meeting the expenditures of Dio's second consulship.

3 The first Sasanian king. He put down the Parthian Arsacid dynasty between 224 and 226, and ruled from those years up to 241. See Josef Wiesehöfer, 'Das Reich der Sasaniden', in KlausPeter Johne, Udo Hartmann and Thomas Gerhardt (eds.), Die Zeit der Soldatenkaiser (Berlin 2008), I, 536-537.

4 Lukas de Blois, 'Emperor and Empire in the Works of Greek-speaking Authors of the Third Century A.D.', in W. Haase and H. Temporini (eds.), Aufstieg und Niedergang der Römischen Welt II 34, 4 (Berlin/New York 1998), 3411-3412. 
This looks like a summary of events, in which details have been left out, and which focuses upon a later phase of the struggle, when mutual distrust had resulted in open violence. In 6.2.2 the author says:

Believing that the entire mainland facing Europe contained by the Aegean Sea and the Propontis Gulf ... belonged to him by ancestral right, he was intending to recover it for the Persian empire.

Severus Alexander, unlike Dio not underestimating the Persian threat, seems to have reacted in full force. If we may believe Herodian 6.3.1, in 230-231 the whole Roman Empire was in a state of complete upheaval because the emperor and his helpers were gathering together a large army to match the reported size of the barbarian invasion. From Italy and all the Roman provinces special levies were recruited for the army.

Aside from Dio and Herodian there is not much evidence that Ardashir and his successor Shapur I (241-270) wished to conquer large parts of the Roman Empire, as far as the Aegean Sea. The only indication one could think of is the composition of the reliefs at Naqsh-i-Rustam, where Sassanian representations were carved into the rock beneath much older Achaemenid royal tombs and sculptures. ${ }^{5}$ Continuity may be suggested here. Still, it is not very plausible that the first Sassanian king had such far-reaching intentions. About 230 Ardashir was still busy to stabilize his power in his own realm. In a number of petty wars he was removing many local princes who were anyhow related to the Arsacid family, appointing new satraps and viceroys in their places, quite a few of whom were related to himself. ${ }^{6}$ Dio's remark about Persian pretensions to restore the old Achaemenid Empire sounds like Roman war propaganda. ${ }^{7}$

5 See David S. Potter, Prophecy and History in the Crisis of the Roman Empire (Oxford 1990), 372376; Josef Wiesehöfer, Das antike Persien von 550 v.Chr. bis 650 n.Chr. (Munich/Zürich 1994), 51-52, 208, and 215-216; Udo Hartmann, Das Palmyrenische Teilreich (Stuttgart 2001), 67.

6 See Hartmann 2001, op. cit. (n. 5), 65; David S. Potter, The Roman Empire at Bay, A.D. $180-$ 395 (London/New York 2004), 222; Richard N. Frye, 'The Sassanians', in Cambridge Ancient History XII ${ }^{2}$ (Cambridge 2005), 465-467; Wiesehöfer 2008, op. cit. (n. 3), 536. Ardashir not only defeated the Parthians and many local rulers, but — unlike his Parthian predecessorsthe Sassanian ruler removed many local princes and appointed members of his own family in their places, as his lieutenants. See Frye, op. cit. 467.

7 See Cassius Dio 80. 4. 1; Herodian 6. 2. 2; Zonaras 12. 15. That the Persians wanted to restore the old Achaemenid empire was a Roman propagandistic view; the aims of the Persian king were much more restricted. See John Drinkwater, "The 'catastrophe' of 260 ", Rivista storica dell'antichità 19 (1989), 126; Potter 1990, op. cit. (n. 5), 372-376; Potter 2004, op. cit. (n. 6), 223-225; Erich Kettenhofen, 'Einige Überlegungen zur sasanidischen Politik gegenüber Rom 
Ardashir's strategy was quite different: he tried to eliminate Arsacid remnants in Armenia, and conquer places such as Hatra, which invading Romans-or Arsacids from Armenia - would be needing as a base and storage facility, if they should set out to conquer Southern Mesopotamia, the Parthian and Persian Empire's main agrarian and trading area, which was their most important tax territory. ${ }^{8}$ According to Stefan Hauser, Ardashir was just attempting to restore the Arsacid Parthian Empire as it had been before the wars of Lucius Verus and Septimius Severus. ${ }^{9}$ This may very well be right, but it cannot be proven. In his article in the same volume, Benjamin Isaac still adheres to the opinion that Persian demands were consistently more militant than the Parthian ones had been. ${ }^{10}$

The main reason for the ensuing war between the Romans and Persians is explicitly mentioned by Dio: distrust among Roman rulers and their governors about the growing military force that Ardashir was gathering. On the Persian side there may have been a fear of Romans assisting the Arsacids, and of Roman outposts being very near Southern Mesopotamia, their most important tax territory. Among these outposts were the caravan city of Palmyra, with its string of forts along the Euphrates, ${ }^{11}$ Dura Europos, a stronghold founded about 303 BC by the Seleucids on the intersection of an east-west trade route and the trade route along the Euphrates, ${ }^{12}$ and from about 229 also Hatra, which had gone over

im 3. Jh.n.Chr., in E. Dabrowa (ed.), The Roman and Byzantine Army in the East (Krakow 1994), 99-108; idem, 'Die Einforderung der achaimenidischen Territorien durch die Sasaniden-eine Bilanz', in S. Kurz (ed.), Festschrift Iradj Khalifeh-Soltani zum 65. Geburtstag (Aachen 2002), 50-75; Hartmann 2001, op. cit. (n. 5), 67; and Karin MosigWalburg, Römer und Perser vom 3. Jh. bis zum Jahr 363 n. Chr. (Gutenberg 2009), 19-23.

8 On the Arsacids in Armenia after 224 see C.S. Lightfoot, 'Armenia and the Eastern Marches', in Cambridge Ancient History XII ${ }^{2}$ (Cambridge 2005), 491-493; Erich Kettenhofen, 'Die kaukasischen Reiche', in Klaus-Peter Johne, Udo Hartmann and Thomas Gerhardt (eds.), Die Zeit der Soldatenkaiser (Berlin 2008), I, 480-483.

Stefan R. Hauser, 'Where is the Man of Hadr, who once Built and Taxed the Land by the Tigris and Chaboras? On the Significance of the Final Siege of Hatra', in Lucinda Dirven (ed.), Hatra. Politics, Culture and Religion between Parthia and Rome (Stuttgart 2013), 139. Benjamin Isaac, 'Hatra against Rome and Persia: From Success to Destruction', in Lucinda Dirven (ed.), Hatra. Politics, Culture and Religion between Parthia and Rome (Stuttgart 2013), 28.

11 On Palmyra and its outposts see Raphaela Drexhage, Untersuchungen zum römischen Osthandel (Bonn 1988), 61-86; Hartmann 2001, op. cit. (n. 5), 52-8; Maurice Sartre, ,The Arabs and the Desert Peoples', in Cambridge Ancient History $\mathrm{XII}^{2}$ (Cambridge 2005), 511-514.

12 On Dura-Europos and the praetentura (military district) of the Middle Euphrates, see Denis Feissel and Jean Gascou, 'Documents d'archives romains inédits du Moyen 
to the Roman side, probably because it had been (unsuccessfully) attacked by the Persians. ${ }^{13}$ There are traces of Roman military presence at Hatra in 235 and 238 , as indicated by three Latin inscriptions. ${ }^{14}$ The Persians may also have been interested in trading centres such as Nisibis. That the Persian leaders thought along these lines is indicated by the persistency with which they kept attacking Hatra, Dura, and Nisibis. Hatra they took and destroyed between 12 April 240 and 1 April 241, after a preceding unsuccessful siege in 229. The Persians made a tremendous effort. The most extended siege works known in the Near East were recently detected at Hatra. Stefan Hauser and David Tucker, the excavators, date the structures to the conquest by Ardashir I in AD 240/241. ${ }^{15}$ Dura was taken by the Persians in 256 , after preceding attacks in 239 and $252 / 253 \cdot{ }^{16}$ Nisibis was a bone of contention from the reign of Gordian III until 262, when it was destroyed by the Palmyrene prince Odaenathus, the emperor Gallienus'

Euphrate (III ${ }^{\mathrm{e}}$ siècle après J.-C.)', Journal des Savants (1995), 102-103. See also Fergus Millar, The Roman Near East, ${ }_{1} B C-A D 337$ (London/Cambridge, MA 1993), 131-133.

13 On Ardashir attacking Hatra in 229 (or even 228) see Cassius Dio 80. 3. 2.

$14 A E$ 1958, 238-240. See Erich Kettenhofen, Die römisch-persischen Kriege des 3.Jahrhunderts n. Chr: nach der Inschrift Šāhpuhrs I. an der Ka'be-ye Zartošt (ک̌KZ) (Wiesbaden 1982), 21; Isaac 2013, op. cit. (n. 10), 27, and Hauser 2013, op. cit. (n. 9), 131. Benjamin Isaac is dating the Roman presence at Hatra too late, to $238-240$. Roman military had not yet been at Hatra in 229, when Ardashir had vainly attacked the stronghold, but they were there about 235 .

15 <http://www.dainst.org/sites/default/files/media/abteilungen/orient/redaktion/zora2 hauser_-_tucker.pdf?ft=all> (10 December 2013). See Hauser 2013, op. cit. (n. 9), 122-133. That Hatra was taken between 12 April 240 and the first of April 241 is attested by Codex Manichaeus Coloniensis 18.1-16, ed. Koenen \& Römer, 10-12. See Kettenhofen 1982, op. cit. (n. 14), 20; Hauser 2013, op. cit. (n. 9), 121.

16 See $S E G$ VII 1934, 743b, ll. 17-19, a Greek graffito from the house of Nebuchelus at Dura, which tells us that on the 3oth day of the month of Xandikos of the year $55^{\circ}$ (Seleucid era, equivalent to 20 April 239) the Persians descended upon Dura-Europos (without taking it). See Ulrich Huttner, 'Von Maximinus Thrax bis Aemilianus', in Klaus-Peter Johne, Udo Hartmann and Thomas Gerhardt (eds.), Die Zeit der Soldatenkaiser (Berlin 2008), I, 182 n. 187 (Persian attack in 239), 219 with n. 523 (Persians possibly in Dura in 253). On Dura being taken in 256 see Kettenhofen 1982, op. cit. (n. 14), 77-83; Jean Gascou, 'Unités administratives locales et fonctionnaires romains. Les données des nouveaux papyrus du Moyen Euphrate et d'Arabie', in Werner Eck (ed.), Lokale Autonomie und römische Ordnungsmacht in den kaiserzeitlichen Provinzen vom 1. Bis 3. Jh. (Munich 1999), 71; Andreas Goltz and Udo Hartmann, 'Valerianus und Gallienus', in Klaus-Peter Johne, Udo Hartmann and Thomas Gerhardt (eds.), Die Zeit der Soldatenkaiser (Berlin 2008), I, 237 (Dura taken and destroyed in 256). 
virtual viceroy in the East, allegedly because it had become pro-Persian. ${ }^{17}$ The first time the Persians took Nisibis and Carrhae cannot be dated to the reign of Maximinus Thrax, but must have followed the demise of Hatra, and elicited Gordian's great campaign of $242-244 .{ }^{18}$

That conquering and occupying the eastern Roman provinces that were situated between Mesopotamia and the Aegean Sea was not the Persian aim of war is also indicated by the way in which Persian armies campaigned in $25^{2-253}$ and 259-261. After initial victories, in 253 at Barbalissos at the northward bend in the river Euphrates, and in 260 at Edessa, where they took the Roman emperor Valerian prisoner, they spread out in groups to loot and plunder. As Fergus Millar remarks: "Even in the record of his victories put up by Shapur I, the second Sasanid king, makes quite clear that they were simply destructive raids."19 The Persians tried to take home valuables, and deported people without permanently occupying strategic places. In this way they became vulnerable to counter-attacks by remaining Roman units, and by troops of vassal princes, such as Uranius Antoninus of Emesa in 253, and the Palmyrene prince Odaenathus in $260 .^{20}$

The impact of the Persian wars of the mid-third century on Roman imperial power was tremendous. First of all, Roman emperors regularly lost a good deal of their military manpower. Three telling examples.

Having tried to negotiate, though in vain, Alexander and his advisors assembled a large army and departed to the East. He recruited new soldiers, as we have seen, but undoubtedly he took with him as well most of the garrison of Italy and detachments from frontier legions. The idea was to attack Ardashir with three armies, one in the North, through the mountains into Media Atropatene, another one in the South, along the river Euphrates and via the allied Palmyrene strongholds that could provide food and shelter, and the main force with the emperor in the middle, in Northern Mesopotamia. The northern forces were successful, but not decisively so. The central army was too slow,

17 On Nisibis as a bone of contention since the reign of Gordian III see Huttner 2008, op. cit. (n. 16), 178, 182 n. 187, and 214; Goltz and Hartmann 2008, op. cit. (n. 16), 353 (Nisibis in 262 destroyed by Odaenathus; cf. Zosimus 1. 39. 1); Hauser 2013, op. cit. (n. 9), 137.

18 Hauser 2013, op. cit. (n. 9), 137-138.

19 Millar 1993, op. cit. (n. 12), 148. See RGDS 5-9, and 12-15.

20 Uranius Antoninus: H.R. Baldus, Uranius Antoninus of Emesa. Münzprägung und Geschichte (Bonn 1971); Kettenhofen 1982, op. cit. (n. 14), 70-76; Potter 1990, op. cit. (n. 5), 323-328; idem, 2004, op. cit. (n. 6), 249-250, referring to Oracula Sibyllina 13. 147-154 and Malalas 296; Huttner 2008, op. cit. (n. 16), 220-221. Odaenathus in 26o: Festus 23; Orosius 7. 22. 12; Oracula Sibyllina 13. 164-171. See Potter 1990, op. cit. (n. 5), 341-347; Hartmann 2001 138-9; Mosig-Walburg 2009, op. cit. (n. 7), 49-50. 
and thus gave the Persians the opportunity to concentrate first on the southern Roman wing, which was annihilated, and then to fight the main Roman force. A big battle between Alexander and the Persians resulted in a costly draw, and subsequently the emperor and many of his men fell ill and retreated to Antioch to recover. The northern army was summoned back to Syria and sustained heavy losses in the mountainous area it had to cross. Remarkably enough, Ardashir did not follow up his successes, probably because he had lost a good deal of his forces as well. If we may believe Herodian, he retreated, accepted a kind of armistice, which lasted three or four years, and disbanded his army (Herodian 6.6.4-6). ${ }^{21}$

In the Res Gestae Divi Saporis (RGDS), the great inscription of Shapur I $(241-270)$ on the ka'aba at Naqsh-i-Rustam, ${ }^{22}$ we are told that Gordian III in 242 took a sizeable army with him to the East. He, or rather, his advisors, probably wanted to conquer the Persians once and for all. Next to detachments from the Rhine ad Danube armies and troops from Italy, his force seems to have comprised quite a few Germans and other former northern enemies. The RGDS speaks of "a force from the Goth and German realms." Gordian's army was victorious at Rhesaena, in 243 , and took back Nisibis and some other places, but was badly beaten at Misiche at the Euphrates, right at the point where the Roman army would have entered the fertile Southern Mesopotamia. This must have taken quite a few lives. ${ }^{23}$ In 252 , another round of Persian wars began. In RGDS $4-5$ we read:

21 On Alexander's eastern campaign see Herodian 6. 5-6; Zonaras 12. 15. See Potter 1990, op. cit. (n. 5), 378-380; Maurice Sartre, The Middle East under Rome (London/Cambridge, MA 2005), 343; Brian Campbell, 'The Severan Dynasty', in Cambridge Ancient History XII ${ }^{2}$ (Cambridge 2005), 25-26; Michel Christol, L'empire romain du IIIe siècle, 192-325 apr. J.-C., 2nd ed. (Paris 2006), 73-74.

22 This inscription starts with Shapur I's accession to the throne and culminates in Valerian's demise in AD 26o. Fergus Millar, 'Government and Diplomacy in the Roman Empire during the First Three Centuries', in H.M. Cotton and G.M. Rogers (eds.), Government, Society and Culture in the Roman Empire (Chapel Hill NC/London 2004), vol. 2, 197, says: "As such, it (=RGDS) represents very accurately the drastic nature of the third-century crisis of the Empire. In this phase of the history of the Roman Empire an emperor may be captured in person in the field, be killed in battle, have to treat for terms, or pay his enemy money to obtain peace."

23 RGDS 3-4: "When at first we had become established in the Empire, Gordian Caesar raised in all of the Roman Empire a force from the Goth and German realms and marched on Babylonia against the Empire of Iran and against us. On the border of Babylonia at Misiche, a great frontal battle occurred. Gordian Caesar was killed and the Roman force was destroyed. And the Romans made Philip Caesar. Then Philip Caesar came to us for terms, and to ransom their lives, gave us 500,00o denars (probably aurei), and became 
And Caesar lied again and did wrong to Armenia (probably helping the Arsacid remnants surviving there). Then we (= the Persian king Shapur I and his army) attacked the Roman Empire and annihilated at Barbalissos a Roman force of 60,000 , and Syria and the environs of Syria we burned, ruined and pillaged all. In one campaign we conquered of the Roman Empire fortresses and towns (then follows a catalogue of conquered places, among them Antioch).

In 253 Shapur I defeated the Roman forces of the East at Barbalissos, plundered Syria, took Antioch, and went back home, probably because Roman remnants and vassals had caused a lot of trouble for his army. In the same year, 253, another Persian force conquered Armenia. ${ }^{24}$ In 256 or 257 Shapur at last conquered Dura-Europos. ${ }^{25}$ In 259-26o the Roman emperor Valerian fought the Persians in a long campaign. Like Severus Alexander before him, he lost

tributary to us" (transl. Richard N. Frye, The History of Ancient Iran [Munich, 1983], appendix 4, 371-372). On Gordian's campaign see Millar 1993, op. cit. (n. 12), 153-154. On Gordian's defeat and death see Oracula Sybillina 13. 13-20, with Potter 1990, op. cit. (n. 5), 36 and 202-211, and Ammianus Marcellinus 23.5.17: redissetque pari splendore iunior Gordianus, cuius monumentum nunc vidimus honorate, apud Resainan superato fugatoque rege Persarum, ni factione Philippi praefecti praetorio sceleste iuvantibus paucis in hoc, ubi sepultus est, loco vulnere impio cecidisset (... the younger Gordianus, whose monument we just now looked upon with reverence, would have come back with equal glory [to Trajan's, Verus', and Severus'], after vanquishing the Persian king and putting him to flight at Resaina, had he not been struck down by an impious wound inflicted by the faction of Philippus, the praetorian prefect, and a few wicked accomplices, in the very place where he now lies buried). More evidence is mentioned by Christian Körner, Philippus Arabs. Ein Soldatenkaiser in der Tradition des antoninisch-severischen Prinzipats (Berlin/ New York 2002), 75-85. On the many losses Gordian's army had to sustain see Richard P. Duncan-Jones, 'Economic Change and the Transition to Late Antiquity', in Simon Swain and Mark Edwards (eds.), Approaching Late Antiquity. The Transition from Early to Late Empire (Oxford 2004), 21-22.

24 See Ammianus Marcellinus 23. 5. 3; Oracula Sibyllina 13. 89-136; Zosimus 1. 27. 2, and the sources mentioned by M.H. Dodgeon and S.N.C. Lieu, The Roman Near Eastern frontier and the Persian wars, A.D. 226-363 (London/New York, 2nd ed., 1994), 49-55. See Kettenhofen 1982, op. cit. (n. 14), 38-43 (Armenia, and Hormizd's campaign, cf. pp. 83-87); 50-52 (rapid Persian march along the Euphrates, passing by of fortresses such as Dura); 53 (battle at Barbalissos); 56-59 (Persians plundering); 59-65 (fall of Antioch, 253). See also Millar 1993, op. cit. (n. 12), 159-162; Potter 2004, op. cit. (n. 6), 248-250; Christol 2006, op. cit. (n. 21), 126-127.

25 Kettenhofen 1982, op. cit. (n. 14), 77-83; D. MacDonald, 'Dating the Fall of Dura-Europos', Historia 35 (1986), 45; Millar 1993, op. cit. (n. 12), 162-163. 
many soldiers to disease. In 260 , he realized that he had become too weak to beat the Persians, amassed a lot of gold to buy them off, but in the end engaged the Persians near Edessa to relieve that important stronghold. Valerian was defeated and taken prisoner. The Persians again invaded the Roman empire, through Syria and a more northerly route. They spread out to plunder, and thus again became vulnerable to counter-attacks, in this case by Roman remnants under Ballista and the troops of the Palmyrene prince Odaenathus, a Roman ally. The Persians had to leave the Roman provinces, and had in 262 and 266 to sustain two invasions by Odaenathus, who commanded not only his own forces, but also remaining Roman units. ${ }^{26}$ Again many Roman soldiers' lives had been lost, and not only among the units of the eastern armies. An inscription proves that Valerian was at Cologne in 257, together with his son and co-emperor Gallienus. ${ }^{27}$ Starting from Cologne, he probably went all along the Rhine and Danube border regions to the East, assembling vexillationes from the legions, auxilia, and Germanic and other foreign allies on his way. The Persian king Shapur's Res Gestae Divi Saporis indicates that Valerian's army consisted of detachments and units from almost every part of the Roman empire, with Germanic allies. ${ }^{28}$ A good part of this army died in the East, either through the plague, which was rampant again since $25^{2},{ }^{29}$ other diseases, or actual warfare, leaving behind many open spaces along the Rhine and Danube. From the Vindolanda tablets we know how many soldiers and officers were regularly absent from their stations in a relatively peaceful period, and under Valerian and Gallienus, it must have been much worse. Furthermore, Gallienus concentrated many vexillationes and cavalry units in his new mobile army, with which he tracked down and annihilated groups of invaders who had dispersed

26 On the campaigns of 259-26o and Odaenathus' raids into the Persian Empire see Oracula Sibyllina 13. 155-171; Aurelius Victor, Caesares 32. 5; Eutropius 9. 7; Petrus Patricius, in Karl Otfried Müller, Fragmenta Historicorum Graecorum Iv (Paris 1851), 187, frg 9; Zosimus 1. 36. 1-2 and 1. 39. 1-2; Zonaras 12. 23; Syncellus 466. See Kettenhofen 1982, op. cit. (n. 14), 97-126; Millar 1993, op. cit. (n. 12), 166-169; Goltz and Hartmann 2008, op. cit. (n. 16), 247-254, 257-62, 271.

27 Charlotte Roueché, Aphrodisias in Late Antiquity (London 1989), 4-8, nr. 1, a fragmentary letter of Valerian and Gallienus written from Cologne, dated 23 August 257. See Millar 1993, op. cit. (n. 12), 164 n. 22; Goltz and Hartmann, 'Valerianus und Gallienus', 238 n. 84.

28 RGDS 9-11.

29 On the plague of $25^{2}$ and its effects see Eutropius 9. 5; Eusebius HE 7. 21-22; Aurelius Victor, Caesares 30. 2; Orosius 7. 21. 5; 7. 27. 10; Zosimus 1. 26. 2, and Zonaras 12. 21. In Oracula Sibyllina 13.106 it is briefly mentioned. 
their forces to plunder. ${ }^{30}$ Those detachments seldom returned to their original stations.

Another effect of the Persian wars of the mid-third century was the undermining of the dominant imperial victory-ideology. As Carlos Noreña makes clear, Victoria always stood as the central imperial ideal around which all others, such as peace, stability, prosperity, and felicitas saeculi circled. Noreña shows that the centrality of Victory is clear from numismatic evidence. ${ }^{31} \mathrm{We}$ might add that it is one of very few messages from imperial coinage that is also massively found on local coins, in various Greek-speaking provinces, and in dating formulas of papyrus texts from Egypt, ${ }^{32}$ and not just on imperial coinage. If the Romans' eternal potential for victory was put into jeopardy, a loss of authority, resulting in usurpations and self-help, was to be expected, and did actually come about. And put into jeopardy it was. Severus Alexander's expedition resulted in a draw, and his soldiers resented his lack of success. But

30 See Alan K. Bowman and J. David Thomas, The Vindolanda Writing-Tablets (Tabulae Vindolandenses II) (London 1994), 90-98, nr. 154 (strength report of the First Cohort of Tungrians), and pp. 98-100, nr. 155. Nr 154 (esp. p. 92) shows that 119 out of $75^{2}$ men were not involved in any border duty, and 337 were stationed at another post, at Corbridge (Coria). The 337 doing duty at Corbridge did not weaken frontier defenses. In the period of crisis under Gallienus, however, sizeable percentages of northern frontier units must have disappeared to the East or to Gallienus' new mobile army, not to another frontier station. On Gallienus' new army, consisting of cavalry and infantry detachments, see Michel Christol, 'La carrière de Traianus Mucianus et l'origine des protectores', Chiron 7 (1977), 393-408.; H.-G. Simon, 'Die Reform der Reiterei unter Kaiser Gallien', in W. Eck, H. Galsterer and H. Wolff (eds.), Studien zur antiken Sozialgeschichte. Festschrift F. Vittinghoff(Vienna/ Cologne 1980), 435-451; Martijn Nicasie, Twilight of Empire. The Roman Army from the Reign of Diocletian until the Battle of Adrianople (Amsterdam 1998), 36-37; Pierre Cosme, L'armée romaine (Paris 2009), 212-215.

31 Carlos F. Noreña, Imperial Ideals in the Roman West (Cambridge 2011), 77-82 (Virtus Augusti), 109, and 147-165 (victory ideology on imperial coins). Cf. Erika Manders, Coining Images of Power. Patterns in the Representation of Roman Emperors on Imperial Coinage (Leiden/Boston 2012), 77-87.

32 On victory-symbols on local coinage see W.H. Waddington, E. Babelon and Th. Reinach, Recueil général des monnaies grecques d'Asie Mineure (Paris 1904/1912), 272-639; idem (Paris 1925), 45, 95, 161; R. Ziegler, Kaiser, Heer und städtisches Geld. Untersuchungen zur Münzprägung von Anazarbos und anderer ostkilikischen Städte (Vienna 1993), 272-275, 288, 317; K. Emmeth, Alexandrian Coins (Lodi wi 2001), 123-206; K. Butcher, Coinage in Roman Syria. Northern Syria, 64 B.C.-A.D. 253 (London 2004), 380-473 (catalogue). On the epithet anikètos in imperial titulature in papyrus texts in the third century AD, see Janneke de Jong, Emperors in Egypt. The Representation and Perception of Roman Imperial Power in Greek Papyrus Texts from Egypt, AD 193-284 (diss. Nijmegen 2006), 107-110. 
Gordian III and Valerian lost great battles, and died, or were taken prisoner. The bad thing was that all three emperors had assembled large armies, thus creating great expectations about their imminent successes.

Thirdly, the Persian wars of the mid-third century had a strong impact on imperial finances, and strained imperial infrastructures. Marching armies cost more than standing forces that could produce something, and were regular customers, in a given place. Under Septimius Severus, Caracalla, Gordian III, and Philip, so well before the intense military activity of the period 249-284, villagers from Euhippe (Asia), Takina (Phrygia), Skaptopare (Thrace), Aragua (Asia), and some other places in the neighbourhood of military transit routes complained to the emperors, telling them that soldiers turning off the main roads had been harassing them, and that military avarice and misbehavior had brought them into misery and bankruptcy, which would ultimately lead to anachoresis (flight from the land) and lower tax returns from their regions. ${ }^{33}$ Such complaints suggest that foodstuffs and commodities stored in fortified warehouses and towns along the roads were not sufficient to keep all marching soldiers satisfied, and that the military did not receive enough money to compensate villagers and townspeople, from whom the soldiers took what they needed.

Roman emperors such as Philip the Arabian and Valerian had, on top of their normal wartime expenses, to find money to pay off the Persians. After the Roman defeat at Misiche, in 244, and the death of Gordian III, Philip made his peace with the Persians, probably without permanently giving up any territory, but he had to recognize Persian primacy in Armenia, and to ransom many Roman soldiers (at a cost of 500,000 denarii). He also agreed to pay a probably annual tribute. ${ }^{34}$ Coming on top of subsidies to the Goths, who had received

33 See Tor Hauken, Petition and response. An epigraphic study of petitions to Roman emperors 181-249 (Bergen 1998), 203-214 (Tabala, AD 193), 215-216 (Euhippe, AD 211-213), 217-243 (Takina in Phrygia, AD 212-213), 74-139 (Skaptopara in Thrace, to Gordian III), 140-161 (Aragua in Phrygia, to Philip). See Stephen Mitchell, 'The Administration of Roman Asia from 133 BC to AD 250', in Werner Eck (ed.), Lokale Autonomie und römische Ordnungsmacht in den kaiserzeitlichen Provinzen vom 1. bis 3.Jh. (Munich 1999), 41; idem, Anatolia. Land, Men and Gods in Asia Minor I: the Celts and the impact of Roman rule (Oxford, 2nd ed., 2001), 228-235.

34 See RGDS 3-4: "On the border of Babylonia at Misikhe a great frontal battle occurred. Gordian Caesar was killed and the Roman force was destroyed. And the Romans made Philip Caesar. Then Philip Caesar came to us for terms, and to ransom their lives, gave us 500,000 denars, and became tributary to us. And for this reason we have renamed Misikhe Peroz-Shapur." Christol 2006, op. cit. (n. 21), 100, speaks of 500,000 'pièces d'or', and Huttner 2008, op. cit. (n. 16), 189-9o of aurei, but RGDS explicitly mentions denarii, 
money since 238, and the unavoidable donatives to the armed forces, which according to Zosimus 1.19.1 were large, ${ }^{35}$ this must have resulted in financial stress.

In 260 the emperor Valerian was beset by many problems. In one of the extant fragments of his work, Petrus Patricius tells us that in that year, Valerian, having lost many men to the plague, amassed an enormous amount of gold to buy off Shapur, because he now had too few troops left to beat his opponent. ${ }^{36}$ To be able to take over the plate needed to produce local coins, Valerian made an end to local coinage in the East. ${ }^{37}$

In conclusion. Were the Persian wars of the mid-third century just a trigger, the occasion that provoked a long imminent crisis in a potentially unstable administrative and social system? I am not so sure. Roman loss of face and setbacks in military personnel in the East were so tremendous, that they could easily induce other enemies, on the northern borders, to attack and plunder the empire in their turn, thus causing permanent and simultaneous threats and outright warfare along ever more frontiers. This was the main cause of crisis, not just a trigger.

and Shapur, the author, was certainly not in to modesty about his successes. On this peace treaty see Körner 2002, op. cit. (n. 23), 120-134.

35 This is one of the very few passages in his work where Zosimus says something of this kind.

36 Petrus Patricius, in: Müller, Fragmenta Historicorum Graecorum IV, p. 187, frg 9.

37 See Ziegler 1993, op. cit. (n. 32), 153-154; Butcher 2004, op. cit. (n. 32), 49, 261-264; Johannes Nollé, 'Bronzene Reflexe einer Krise. Das städtische Münzwesen Kleinasiens als Indikator von Phänomenen der Reichskrise des 3. Jahrhunderts und von zeitgenössischen Krisenempfinden', in Klaus-Peter Johne, Thomas Gerhardt and Udo Hartmann (eds.), Deleto paene imperio Romano. Transformationsprozesse des Römischen Reiches im 3. Jahrhundert und ihre Rezeption in der Neuzeit (Stuttgart 2006), 284. 


\title{
The Emperor Beyond the Frontiers: A Double-Mirror as a 'Political Discourse'
}

\author{
Stéphane Benoist
}

1

This is a contribution about 'an imperial discourse' in which long-term notions of the Roman Empire in the worlds outside of that empire, and of the outside worlds from within the Roman Empire, are related to the multiple figures of the princeps. It raises diverse (Roman and alien) conceptions of the imperial power during the first five centuries of the Principate, and analyses the various messages we can find during periods of peace and war. Epigraphic, numismatic, juridical, and iconographic evidence, e.g., from the Res Gestae diui Augusti to the so-called Res Gestae diui Saporis, is used to analyse different aspects of the conception of the princeps by insiders and outsiders. ${ }^{1}$

This contribution is part of a research program which interprets the imperial identity through the various 'forms, practices, and representations of the imperial power at Rome and in the Roman world from the beginnings to the Late Antique Empire.' The process of construction of a discourse involving a sort of 'double-entendre' ${ }^{2}$ (various meanings depending on diverse audiences) will be the main focus of this inquiry. It sees political discourse essentially as part of a dialogue, in which rhetoric plays a crucial role. ${ }^{3}$

1 For a few preliminary aspects about the frontiers of the Roman Empire and the conception of imperial power: Stéphane Benoist, 'Penser la limite: de la cité au territoire impérial', in Olivier Hekster and Ted Kaizer (eds.), Frontiers in the Roman World, Proceedings of the Ninth Workshop of the International Network Impact of Empire (Durham, 16-19 April 2009), (Leiden/Boston 2011), 31-47.

2 About 'double-entendre' and the nature of a 'subtext,' see Stéphane Benoist, 'Fragments de mémoire, en quête de paroles condamnées', in Bénédicte Delignon and Yves Roman (eds.), Le Poète irrévérencieux. Modèles hellénistiques et réalités romaines, collection du CEROR 32 (Paris 2009), 49-64, for a general overview.

3 E.g. Stéphane Benoist, 'Identité(s) du prince et discours impérial, l'exemple des titulatures, des Sévères à Julien', in Moïra Crété (ed.), Discours et systèmes de représentation: modèles et transferts de l'écrit dans l'Empire romain (Besançon 2016) forthcoming; and the conclusion of the same volume: Id., 'Miroir des princes et discours d'éloge, quelques remarques 
This interpretation of imperial power can be illustrated through two wellknown situations at the margins of the Imperium Romanum. Both deal with the apparatus of the emperor handling foreign embassies. The two examples show how, on the one hand, the image of an all-powerful Rome, which had dominated the first three centuries of the Principate, is still put forward in the second half of the third century, but contrasts sharply with testimonies produced by enemies of Rome during the second part of the 3 rd, or during the 4 th and 5 th centuries $\mathrm{AD}{ }^{4}$

Dexippus, in a fragment, describes Aurelian's negotiations with the Iuthungi, in probably $270 .{ }^{5} \mathrm{He}$ gives us a very interesting description: the army was arranged around the prince, who was seated on a high stage, as accompanied by eikones Basileioi and gold eagles. ${ }^{6}$ Those signa and imagines were taken from the sacellum of the military camp, and were used to boost the notion of solemnity at the reception of the ambassadors of the Iuthungi. This spectacular imperial manifestation will certainly have impressed the visitors; but what was the real meaning of this staging? For whom was it primarily intended? Was it chiefly aimed at the Roman soldiers (insiders), or at the foreign ambassadors (outsiders)? Was it meant to give the Roman emperor the necessary auctoritas to maintain his power under very difficult circumstances, or did it seek to inspire awe into his enemies (the latter being the traditional interpretation of the passage) $?^{7}$ The physical link that was created between the ruler (Aurelian) and his predecessors (the diui $=$ eikones basileioi) created a concrete expression of the eternity of Rome (Roma Aterna) and of the statio

conclusives'; Id., 'Rhétorique, politique et pratique épigraphique monumentale', Cahiers $d u$ Centre Gustave Glotz 25 (2014), 209-214.

4 See the accurate inquiry by Audrey Becker, Les relations diplomatiques romano-barbares en Occident au $V^{e}$ siècle. Acteurs, fonctions, modalités (Paris 2013) on this radical change of perspectives from a conquering Rome to a much more disputed situation.

5 Jacoby FGRH II.A = Dex., Frag. 6.3.

6 For a commentary about 'the images of emperor and empire' citing this testimony (i.e. Excerpta de legationibus, Dexippus 1 de Boor [ $F H G$ fr. 24 = Dindorf, $H G M$ fr. 22]), see Clifford Ando, Imperial Ideology and Provincial Loyalty in the Roman Empire (Berkeley 2000), 263.

7 E.g. Ando 2000, 263: "On the appointed day, the emperor ordered the legions to assemble as if for battle, to terrify the enemy (...) Aurelian's preparations were successful: the Juthungi, we are told, were stunned and remained silent for a long time." 
principis (Æternus Augustus or perpetuus Augustus), visible to every participant in this political ritual. ${ }^{8}$

About a century later, the situation had changed profoundly. Ammianus Marcellinus gives us an account of the meeting between Athanaric's Visigoths and the emperor Valens in order to prepare the treaty of 369 . It was finally concluded in the middle of the Danube, because neither the Romans nor the Visigoths were able to convince the others to cross the river. "Because Athanaric asserted that an oath pronounced with formidable curses stopped him from ever walking on Roman ground, that his father in his recommendations had forbidden it, and that it was, moreover, impossible to oblige him to do so, and because on the other hand the emperor would have to dishonour himself and stoop to crossing the river to meet him, some counsellors with a straight judgment decided that ships should be rowed into the middle of the river, the one carrying the emperor with his guards, the other the judge of the people of this country with his own guards, to conclude the peace in the terms that had been agreed upon."9 As a matter of fact, the weakness of the Roman Empire was demonstrated clearly, as was the importance of the physical presence of the emperor, at the Danube frontier during the second part of the 4th century AD.

In the period of time between our two introductory examples, several orators still tried to celebrate an imperium sine fine, but it no longer existed. Panegyrists may have asserted that "beyond the Rhine everything is Roman!",10

8 See Stéphane Benoist, 'Images des dieux, images des hommes. Réflexions sur le 'culte impérial' au II I ${ }^{\mathrm{e}}$ siècle', in Marie-Henriette Quet (ed.), La "crise" de l'empire romain de Marc Aurèle à Constantin (Paris 2006), 27-64: the display of imagines of deceased emperors, probably the diui, reminds us of Decius' use of a monetary series of diui from Augustus onwards. The conception of the Eternity of the Empire and the emperor was central from the very beginning of the Principate, but increasingly became so during the 3 rd century $\mathrm{AD}$ : Stéphane Benoist, Rome, le prince et la Cité. Pouvoir impérial et cérémonies publiques ( ${ }^{\text {er }}$ siècle av.-début du IV siècle ap.J.-C.), collection Le Nœud Gordien (Paris 2005), chapters VII-VIII, 273-333.

Amm. Marc. XXVII.5.9: et quoniam adserebat Athanaricus sub timenda exsecratione iurandi se esse obstrictum, mandatisque prohibitum patris ne solum calcaret aliquando Romanorum, et adigi non poterat, indecorumque erat et uile ad eum imperatorem transire, recte noscentibus placuit, nauibus remigio directis in medium flumen, quae uehebant cum armigeris principem gentisque iudicem inde cum suis, foederari, ut statutum est, pacem. Becker 2013, op. cit. (n. 4), quotes this passage in her introduction (15-16), underlining the symbolic aspect of the Danube as an appropriate space belonging to nobody, neither the Romans, nor the Visigoths.

10 Mamertinus, Maximiano Augusto, Pan. 10 [II].7.7: quidquid ultra Rhenum prospicio, Romanum est. 
and that "in its peaceful embrace the Roman power (Romana res publica) embraces all which, in the succession and the diversity of time, was at some moment Roman, and this greatness, which often had tottered as under an excessive weight, found its cohesion in an ultimately unshakable Empire (solido imperio)."11 However, the Pax Romana embodied by the Imperator Caesar Augustus had failed.

These two case studies illustrate the scope in which an empire made of words differed from the empire as it was experienced by contemporaries. It is worth while to consider this in perspective of 'an imperial discourse,' composed of words, monuments, and acts. This will help us to understand relationships between 'Ours' and 'Theirs', insiders and outsiders, Romans and Barbarians in the period from Augustus to Theodosius.

Following the two examples from the Rhine and Danube limites in the 3 rd and the 4th centuries AD, we will further concentrate on the Oriental frontier, looking at diplomatic as well as military relationships between Romans and Parthians/Persians, from the very beginnings of the Empire onwards. Some relevant elements are already visible in the so-called "Königin der Inschriften"; the famous Res Gestae diui Augusti. ${ }^{12}$ Five passages that are important in this context deal with Armenian affairs (27.2), the recovery of military standards by Tiberius in Augustus' name (29.2), embassies from faraway kings (31.1-2), royal fugitives and hostages (32.1-2), and finally rulers imposed by Rome to foreign kingdoms (33). They are worth quoting in full:

Although I could have made Greater Armenia a province, on the assassination of Artaxes its king, I preferred, in accordance with the example set by our ancestors, to hand this kingdom over to Tigranes, son of King Artavasdes, and also grandson of King Tigranes, through the agency of Tiberius Nero, who at the time was my stepson. And when the same people later revolted and rebelled, they were subdued through the agency of Gaius, my son, and I handed them over to King Ariobarzanes, son of

11 Constantio Caesari, Pan. 8 [v].20.2: Tenet uno pacis amplexu Romana res publica quidquid uariis temporum uicibus fuit aliquando Romanum, et illa quae saepe ueluti nimia mole diffluxerat magnitudo tandem solido cohaesit imperio.

12 Th. Mommsen, 'Der Rechenschaftsbericht des Augustus', in Gesammelte Schriften IV (Berlin 1906² [1887]), 247 . 
Artabazus King of the Medes, for him to rule, and after his death to his son, Artavasdes; on his assassination, I sent into this kingdom Tigranes, who was descended from the Armenian royal family. ${ }^{13}$

I compelled the Parthians to give back to me spoils and standards of three Roman armies and humbly to request the friendship of the Roman people. These standards, moreover, I deposited in the innermost sanctum, which is in the temple of Mars the Avenger. ${ }^{14}$

Embassies of Kings from India were often sent to me, such as have not ever been seen before this time in the presence of any Roman general. The Bastarnae sought our friendship through envoys, and the Scythians, and kings of the Sarmatians who are on both sides of the river Don, and the king of the Albanians and of the Hiberians and of the Medes. ${ }^{15}$

Kings of the Parthians, namely Tiridates and later Phraates, son of King Phraates, Artavasdes King of the Medes, Ataxares of the Adiabenians, Dumnobellaunus and Tincomarus of the Britons, Maelo of the Sugambri, [?-]rus of the Suebic Marcomanni fled for refuge to me as suppliants. Phraates, son of Orodes, King of the Parthians, sent all his sons and grandsons into Italy to me, even though he had not been conquered in war, but asking for our friendship through pledging his children. And while I have been leader very many other peoples have experienced the good faith of

$13 R G D A$ 27.2: Armeniam maiorem interfecto rege eius Artaxe, $c[u] m$ possem facere prouinciam, malui maiorum nostrorum exemplo regn [u]m id Tigrani, regis Artauasdis filio, nepoti autem Tigranis regis, per $T[i$ (berium) Ne]ronem trade[r]e, qui tum mihi priuignus erat. et eandem gentem postea $d[e]$ sciscentem et rebellantem domit $[a] m$ per Gaium filium meum regi Ariobarzani regis Medorum Artaba[zi] filio, regendam tradidi, et post eius mortem filio eius, Artavasdi; quo [i]nterfecto Ti[gra]ne $\langle m>$, qui erat ex regio genere Armeniorum oriundus, in id regnum misi. Four editions of the Res Gestae Diui Augusti (RGDA) have been published recently: John Scheid, Res Gestae Diui Augusti. Hauts faits du divin Auguste, CUF-Les Belles Lettres (Paris 2007); the English translation follows Alison E. Cooley, Res Gestae Divi Augusti (Cambridge 2009); Stephen Mitchell, David French, The Greek and Latin Inscriptions of Ankara (Ancyra). Vol. I: From Augustus to the end of the third century $A D$, Vestigia 62 (Munich 2012); and Augusto, Res gestae. Imiei atti, a cura di Patrizia Arena, Documenti e studi 58 (Bari 2014).

14 RGDA 29.2: Parthos trium exercit<u>m Romanorum spolia, et signa re[ddere] mihi supplicesque amicitiam populi Romani petere coegi. ea autem si[gn]a in penetrali, quode [s]t in templo Martis Vltoris reposui.

15 RGDA 31:1. ad me ex In [dia regum legationes saepe] $m$ [issae sunt non uisae ante id $t]$ em [pus] apud qu[em $] q[$ uam $] R[$ omanorum $d u]$ cem. 2. nostram amic[itiam appetiue $]$ run $[t]$ per legat $[$ os $] B[a]$ starn [ae Scythae $]$ que et Sarmatarum qui su[nt citra fl] umen Tanaim et ultra re [ges, Alba]norumque rex et Hiberorum e[t Medorum]. 
the Roman people; between them and the Roman people previously no embassies or exchange of friendship has existed. ${ }^{16}$

From me the Parthian and Median peoples received kings, whom they had requested through envoys drawn from their leaders: the Parthians received Vonones, son of King Phraates, grandson of King Orodes, the Medes Ariobarzanes, son of King Artavazdes, grandson of King Ariobarzanes. ${ }^{17}$

These different passages from the RGDA are essential to understand the Roman approach to frontiers, and to notice how a specific conception of space was connected closely to the perception of imperial power (statio principis). It is worth recalling Claude Nicolet's "inventory of the World," which he set out in an essay published in 1988 in French and then in 1991 in English, in which he linked the evolution from a closed to an open space to how new provinces at the borders of the empire could be understood as sorts of "new frontiers."18 We may underline how we can analyse the Augustan monument in that perspective to show what were the main processes that were brought into play.

It is not necessary to re-open the uexata quaestio about the true meaning of the provincial copies of the $R G D A$, nor about the idea of a proper adaptation of the text to this specific Galatian context, through for example the use of an appendix. ${ }^{19}$ More important for the purposes of this paper are the

$16 R G D A$ 32:1. ad me supplices confugerunt [r]eges Parthorum Tirida[te]s et post [ea] Phrat [es], regis Phratis filiu[s], Medorum Ar[tauasdes, Adiabenorum A]rtaxares, Britann[o]rum Dumnobellaunus et Tin[comarus, Sugambr]orum Maelo, Mar[c]omanorum Sueborum [...rus]. 2. ad [me re]x Parthorum Phrates, Orod [i]s filius, filios suos nepot[esque omnes] misit in Italiam non bello superatu[s], sed amicitiam nostram per [libe]ror[um] suorum pignora petens. 3. plurimaeque aliae gentes exper[tae sunt p(opuli) Ro]m(ani) fidem me principe, quibus antea cum populo Roman[o nullum extitera]t legationum et amicitiae [c]ommercium.

RGDA 33: a me gentes Parthorum et Medoru[m per legatos] principes earum gentium reges pet [i] tos acceperunt: Par[thi Vononem, regis Phr]atis filium, regis Orodis nepotem, Medi Arioba[rzanem], regis Artavazdis filium, regis Ariobarzanis nepotem.

18 Claude Nicolet, L'inventaire du monde. Géographie et politique aux origines de l'Empire romain (Paris 1988 [2 éd. 1996]); Space, geography, and politics in the early Roman empire, Thomas Spencer Jerome Lecture 19 (Ann Arbor 1991).

19 The main aspects of the epigraphic survival of the text through Anatolian copies (in Ancyra, Pisidian Antioch, and Apollonia) are developed by Cooley 2009, op. cit., esp. 6-22, and Scheid 2007, op. cit., IX-XIII; XVII-XXI; XXIX-XXXIV, in their editions of the RGDA (n. 13). Cf. P. Thonemann, 'A Copy of Augustus' Res Gestae at Sardis', Historia 61.3 (2012), 282-288, and Arena 2014, op. cit., 14-15, for an Asian copy of the text discovered in Sardis and the consequences of this find for the different attested Greek translations. 
circumstances in which the original text was read out publicly by Tiberius, in his role as imperial successor, followed in this by his son Drusus, who read out the major part of this Augustan auto-evaluation..$^{20}$ The new princeps, reading an evaluation of Augustus' works written by himself, was in this way obliged to publicly respect the main recommendations of his father. Delivering as a speech this Augustan rewriting of the history of Rome, from the civil wars to the last months of his life, in front of sons and nephews of Republicans and Antonians, was a true political ritual. ${ }^{21}$ Tiberius was still under the control of the late pater patriae, his adoptive father, who had held patria potestas over him until he died. Personal relationships and the broad outline of Augustus' politics, the text suggested, should be respected by Tiberius. This very long text could be considered as a form of mandata by the dead emperor (now diuus) to his adoptive son, who had been his legatus during the last period of Augustus' principate.

Performing this act of pietas was a political necessity for Tiberius in the summer of $14 \mathrm{AD}$ (from the 19th of August to the 23rd of September); it presents us with a few lessons: crucial is the personalization of the accounts in the RGDA of political and diplomatic decisions. As is well known, only very few names are mentioned in the text, except the regular presence of Augustus' sons, ${ }^{22}$ and of the kings of Armenia and Parthia. ${ }^{23}$ The personal relationships

20 Cf. Suet., Aug., 101.1: Testamentum L. Planco C. Silio cons. III. Non. Apriles, ante annum et quattuor menses quam decederet, factum ab eo ac duobus codicibus, partim ipsius partim libertorum Polybi et Hilarionis manu, scriptum depositumque apud se uirgines Vestales cum tribus signatis aeque uoluminibus protulerunt. Quae omnia in senatu aperta atque recitata sunt; 6 , Tribus uoluminibus, uno mandata de funere suo complexus est, altero indicem rerum a se gestarum, quem uellet incidi in aeneis tabulis, quae ante Mausoleum statuerentur, tertio breuiarium totius imperii, quantum militum sub signis ubique esset, quantum pecuniae in aerario et fiscis et uectigaliorum residuis; and Tib., 23 (discourse by Tiberius and reading of Augustus' will); Dio Cass., $5^{6.33}$.

21 About this specific dimension and its impact on the normative processes of imperial power, see Stéphane Benoist, 'Noms du prince et fixation de la norme: praescriptio / intitulatio, subscriptio ...', lecture delivered at the Institut de droit romain in Paris (22.3.2013) to be published by the Revue historique de droit français et étranger.

22 Cf. RGDA 8.4: conlega Tib(erio) Cae[sare filio] $m$ [eo; 12.2: Ti(berio) Nerone... cos; 14.1: [ fil]ios meos... Caium et Lucium Caesares; 16.2: Ti(berio) Nerone ... consulibus; 20.3: filiorum $m[$ eorum; 22.1: filiorum meorum aut $n[e]$ potum nomine; nepo[tis] mei nomine; 22.3: filio[ru]m meorum et nepotum; e.g., about Armenia, 27.2: per T[i(berium) Ne]ronem ... qui tum mihi priuignus erat / per Gaium filium meum; 30.1: per Ti(berium) [Ne] ronem, qui tum erat priuignus et legatus meus.

23 Artaxes, Artavasdes, Tigranes, Ariobarzanes with Artavasdes of the Medes in RGDA 27.2; Tiridates, Phraates, in RGDA 32.1-2 with other kings, and in RGDA 33. See Mario Pani, Roma 
between the late Roman emperor and foreign kings are clearly expressed through embassies ( $a d m e$ / a me), and by the regular mention of the amicitia. This will be a permanent structure within Roman imperial history-from the beginnings of the Imperium Romanum with the Republican magistrates to the late Antiquity-. ${ }^{24}$ It is enough to quote the end of $R G D A$ 's chapter 32.3: "And while I have been leader very many other peoples have experienced the good faith of the Roman people ( $p$ (opuli) Ro]m(ani) fidem me principe); between them and the Roman people previously no embassies or exchange of friendship (legationum et amicitiae [c] ommercium) has existed."

Tiberius was forced to accept, through his extensive public reading of the $R G D A$ in the Curia, the Augustan conception of power within and outside of the empire. This applied to power structures between the senate, the people and the princeps in Rome, but also with foreign kings across the frontiers. During the first century of the Principate, these power relations formed the basis of what became a stereotypical discourse to divide between good and bad emperors, making use of private and public behaviour and focusing on

e Ire d'Oriente da Augusto a Tiberio (Cappadocia, Armenia, Media Atropatene) (Bari 1972), chapter I "Lotte dinastiche per l'Armenia e 'reges dati' in eta' augustea," 15-64; Richard D. Sullivan, Near Eastern Royalty and Rome, 100-30 BC (Toronto 1990), 290-291 (Artaxias II), 297-300 (Artavasdes I), 313-318 (Phraates IV); and Marie-Louise Chaumont, 'L'Arménie entre Rome et l'Iran I. De l'avènement d'Auguste à l'avènement de Dioclétien', $A N R W$ II.9.1 (1976), 73-84 ("La politique d'Auguste en Arménie").

24 Cf. RGDA 31-33. About the conception of a Roman diplomacy through the relationships between the emperors and the members of their family (domus Augusta), Stéphane Benoist, 'Les membres de la domus Augusti et la diplomatie impériale. À propos de l'empire et des "autres"', in Audrey Becker and Nicolas Drocourt (eds.), Ambassadeurs et ambassades au coeur des relations diplomatiques, Rome-Occident médiéval-Byzance (viri ${ }^{e}$. avant J.-C.-XII ${ }^{e}$ s. après J.-C.), collection du CRULH 47 (Metz 2012), 65-81. Note how 4thcentury letters between Constantine or Constantius and Shapur II confirm permanent diplomatic activities between emperors and foreign kings: Eusebius, Vita Constantini, 4.9-13 (letter in Latin translated in Greek by Eusebius from Constantine to Shapur), and Ammianus Marcellinus, 17.5 Constantius Aug. et Sapor Persarum rex frustum de pace per litteras et legatos agunt (with two examples of letters from an exchange between Constance and Shapur: 3. Rex regum Sapor, particeps siderum, frater Solis et Lunae, Constantio Caesari fratri meo salutem plurimam dico; 10. Victor terra marique Constantius, semper Augustus, fratri meo Sapori regi salutem plurimam dico); two pieces of evidence quoted by Fergus Millar, 'Emperors, Frontiers, and Foreign Relations, $3_{1}$ B.C. to A.D. 378', Britannia 13 (1982), 1-23 = Hannah M. Cotton, Guy M. Rodgers (eds.), Government, Society, and Culture in the Roman Empire, vol. 2 of Rome, the Greek World, and the East (Chapel Hill and London 2004), 160-194 (at 162). 
the functioning of the domus Augusta. ${ }^{25}$ The portrait of a good ruler could be sketched by portraying how the Roman Empire functioned. An important role was played by looking at the Parthian counterpart to the Roman Empire, and at Armenia placed between these superpowers. There were many family connections and specific mandates for members of the imperial family_Tiberius, Caius, Germanicus, as potential heirs-regarding Armenian and Parthian successions. In that perspective, we can find a genuine Roman 'Parthian' discourse that lays behind the notion of a princeps Parthicus, from Trajan to Lucius Verus, and finally Septimius Severus (see below sections 3 and 5).

The conception of the Roman Empire, between an image of a "coherent geographical and strategic entity bounded by three great rivers: Rhine, Danube and Euphrates" 26 and the ideology of permanent conquest, could be studied through various portraits of emperors. Of particular interest are pairs of Imperatores Caesares Augusti, that show us contrasting views of the Imperium Romanum (Augustus-Tiberius, Trajan-Hadrian, etc.). From Fronto to the Historia Augusta, the complicated "Parthian" question figures prominently in literary evidence showing a strictly Roman "imperial" point of view, e.g., the different attitudes that Roman rulers held regarding peace and war. From Augustus to the 3 rd century AD, one can see the development of a rhetorical process, in which two different imperial identities are contrasted: the idealized $p$ (ius) $f$ (elix) <semper > inu(ictus) emperor, with an impressive titulature, from the last Antonines to Constantine, versus a stereotypical tyrant. ${ }^{27}$

An important aspect of this rhetorical process is presented by the modes to delegitimize an emperor. These can be traced by a precise analysis of the varying rhetoric within our textual and material evidence, literary as well as

25 Benoist 2012, op. cit. (n. 24).

26 Cf. Fergus Millar's seminal essay about 'Emperors, Frontiers, and Foreign Relations', published in 1982 (op. cit. n. 24), 188, with references to Strabo, Velleius, Josephus, Statius, Tacitus, and Suetonius.

27 On the use of tyranus as a term to describe any illegitimate princeps, bad ruler, or usurper: Stéphane Benoist, 'Usurper la pourpre ou la difficile vie de ces autres "principes", in Stéphane Benoist and Christine Hoët-van Cauwenberghe (eds.), La vie des autres. Histoire, prosopographie, biographie dans l'Empire romain, collection Histoire et civilisations (Villeneuve d'Ascq 2013), 37-61. 
epigraphic, from Cicero to the Historia Augusta. ${ }^{28}$ Sometimes, we can find elaborate rhetorical strategies to put forward different portrayals of ruling emperors, or to contrast different members of the domus Augusta.

Two well-known examples may be mentioned: they both use the Parthian/ Persian war and the foreign king as an enemy, in order to contrast imperial behaviour. According to Fronto, who wanted to give advice to his pupil Marcus Aurelius, who according to him had a too much philosophical mind, Lucius Verus behaved better than Trajan during his Parthian campaign: "Lucius, on account of the ingenuity of his advice, is by far the elder of Trajan;"29 Verus sent a letter to his enemy, Vologaeses, offering him peace. He thus cared for the safety of his soldiers, and preferred peace to vain glory, whilst avoiding any treachery. ${ }^{30}$ We may be surprised to find Lucius Verus, who is regularly portrayed as a debauchee, as the ideal prince in Fronto's epistula: "Lucius bears a great reputation of justice and leniency among the Barbarians; Trajan was not equally innocent for all. Nobody has regretted placing his kingdom and fortune under Lucius's protection." ${ }^{11}$ This 'reversed' portrait of Lucius might have been

28 On the various perceptions of an imperial discourse and its own processes of commemoration and denigration of emperors: Stéphane Benoist, 'Cicéron et Octavien, de la res publica au princeps, lectures croisées', in Robinson Baudry and Sylvain Destephen (eds.), La société romaine et ses élites. Hommages à Élizabeth Deniaux, (Paris 2012), 25-34; Id., 'Honte au mauvais prince, ou la construction d'un discours en miroir', in Renaud Alexandre, Charles Guérin and Mathieu Jacotot (eds.), Rubor et Pudor. Vivre et penser la honte dans la Rome ancienne, Études de littérature ancienne 19 (Paris 2012), 83-98; Id., 'Le prince nu. Discours en images, discours en mots. Représentation, célébration, dénonciation', in Valérie Huet and Florence Gherchanoc (eds.), Vêtements antiques. S'habiller et se déshabiller dans les mondes anciens (Paris 2013), 261-277; and finally Id., 'Trahir le prince: lecture(s) de l'Histoire Auguste', in Anne Queyrel Bottineau, Jean-Christophe Couvenhes and Annie Vigourt (eds.), Trahison et traitres dans l'Antiquité, collection De l'archéologie à l'histoire (Paris 2013), 395-408.

29 M. Cornelius Fronto, Epistulae, ed. Michael Petrus Josephus Van den Hout, Teubner (Leipzig 19882), 202-214 (Principia historiae), with Van den Hout's accurate commentary in A commentary on the letters of Marcus Cornelius Fronto (Leiden/Boston 1999), 463-487. Principia historiae $16(<\ldots>$ Lucius consiliorum sollertia longe esse Traiano senior $<\ldots>)$.

30 Fronto, Principia historiae 16-17: recte res gesta:paucis ante diebus $L<u$ ciu $>$ s ad Vologaesum litteras ultro dederat, bellum, si uellet, condicionibus poneret. Dum oblatam pacem spernit barbarus, male mulcatus est. 17. Ea re dilucide patet, quanta Lucio cura insita sit militum salutis, qui gloriae suae dispendio redimere cupiuerit pacem incruentam. Traiano suam potiorem gloriam in sanguine militum futuram de ceteris eius studiis multi coniectant; nam saepe Parthorum legatos pacem precanteis dismisisse inritos.

31 Idem 18: Iustitiae quoque et clementiae fama apud barbaros sancta de Lucio; Traianus non omnibus aeque purgatus. Regnum fortunasque suas in fidem Luci contulisse neminem paenituit. 
written in anticipation of the younger imperator's journey back to Rome, and of his upcoming aduentus and triumphus. As Parthicus, Lucius Verus could be celebrated like a 'good prince.'32

One of the most important aspects of the Roman commemorative identities that took shape in the Augustan Principate was linked to the return to peace (a verbal discourse in Virgil's Aeneid) and to the celebration of diplomatic conquest over the Parthian empire by the recovery of Crassus's lost standards (a monumental discourse through the Parthian Arch in the forum Romanum, and the statue of Prima Porta). The recurrent Parthian wars could be used to demonstrate the uirtus and the fortuna of any emperor. Yet, as we have seen, it was possible to completely inverse the 'normal' perspective and describe Trajan as full of treachery and cruelty towards the Parthian and Armenian kings, whilst Lucius Verus became a good soldier and a general who took care of his legionaries. Consequently, we can argue that the official conception of an empire $a b$ origine rests on a rhetorical construction that diffused inside and outside messages through an imperial stereotypical portrait.

A century later, we find another piece of evidence for this imperial discourse: the portrait of Gallienus, son of the defeated emperor Valerian, who was captured by Shapur. Gallienus is usually condemned by the senatorial historiography for his edictum on military careers and the government of imperial provinces. ${ }^{33}$ In the vita written by the author of the Historia Augusta, the legitimate emperor is condemned as a tyrant, a mollis, while Odaenathus from

32 Note the equally surprising negative description of Trajan in the episode of Parthamasiris' murder as narrated by Fronto in his Principia historiae 18: Traiano caedes Parthamasiri regis sup $<p>$ licis haud satis excusata. Tametsi ultro ille uim coeptans tumultu orto merito interfectus est, meliore tamen Romanorum fama impune supplex abisset quam iure supplicium luisset, namque talium facinorum causa facti latet, factum spectatur, longeque praestat secundo gentium rumore iniuriam neglegere quam aduerso uindicare. "the murder of Parthamasiris, a pleading king, was not enough justified by Trajan. Although he had deserved to be killed, because he had begun on his own initiative the violence at the origin of the disorders, it would have been however preferable for the Roman reputation to let a supplicant leave without any damage rather than to chastise him, because the reasons of such a crime remain obscure: we see only the action, and it is by far preferable to neglect an insult with the public approval that to take revenge of it in the general disapproval." On Armenia under Trajan's rule and its annexation, Chaumont 1976, op. cit. (n. 23), 130-143.

33 See Lukas de Blois, The policy of the emperor Gallienus (Leiden 1976), 57-83, especially 78-80: "The hatred of senators for Gallienus and the emperor's bad name among Latin historians"; and Michel Christol's abstract of his unpublished thesis 'L'État romain et la crise de l'empire (253-268)', L'Information historique 44 (1982), 156-163, with 'Armée et société politique dans l'Empire romain au $\mathrm{III}^{\mathrm{e}}$ siècle ap. J.-C.', Civiltà classica e cristiana 9 (1988), 169-204. 
Palmyra - and to an extent also his wife Zenobia, whose description is ambiguously positive, and shows noble courage and virility ${ }^{34}$ - became the protector of the pars Orientalis of the empire. He defended the Roman territory facing Sapor, and his "sole purpose was to set Valerian free" while the official ruler Gallienus "was doing nothing at all". 35

Romano-Parthian or Persian relationships have been an essential part of the process of constructing an imperial identity from Augustus to Gallienus. The recovery of military standards by Tiberius was celebrated to commemorate the revenge over Crassus's defeat. This became a fundamental act for

34 On the impossibility of a feminine imperium and the use of this topos in our literary evidence, Stéphane Benoist, 'Women and Imperium in Rome. Some imperial perspectives', in Jacqueline Fabre-Serris and Alison Keith (eds.), Women and War in Antiquity (Johns Hopkins University Press, Baltimore 2015), 266-288.

35 For this stereotypical vision of Gallienus facing Odenathus in the Historia Augusta: Gall., $\mathrm{X}, 1$. Gallieno et Saturnino conss. Odenatus rex Palmyrenorum optinuit totius orientis imperium, idcirco praecipue, quod se fortibus factis dignum tantae maiestatis infulis declarauit, Gallieno aut nullas aut luxuriosas aut ineptas et ridiculas res agente. 2. Denique statim bellum Persis in uindictam Valeriani, quam eius filius neglegebat, indixit. 3. Nisibin et Carras statim occupat tradentibus sese Nisibenis atque Carrenis et increpantibus Gallienum. 4. Nec defuit tamen reuerentia Odenati circa Gallienum; nam captos satrapas insultandi prope gratia et ostentandi sui ad eum misit. (...) 6. Odenatus autem ad Ctesifontem Parthorum multitudinem obsedit uastatisque circum omnibus locis innumeros homines interemit. 7. Sed cum satrapae omnes ex omnibus regionibus illuc defensionis communis gratia conuolassent, fuerunt longa et uaria proelia, longior tamen Romana uictoria. 8. Et cum nihil aliud ageret nisi ut Valerianum Odenatus liberaret, instabat cottidie, ac locorum difficultatibus in alieno solo imperator optimus laborabat. "In the consulship of Gallienus and Saturninus Odaenathus, king of the Palmyrenes, held the rule over the entire East chiefly for the reason that by his brave deeds he had shown himself worthy of the insignia of such great majesty, whereas Gallienus was doing nothing at all or else only what was extravagant, or foolish and deserving of ridicule. Now at once he proclaimed a war on the Persians to exact for Valerian the vengeance neglected by Valerian's son. He immediately occupied Nisibis and Carrhae, the people of which surrendered, reviling Gallienus. Nevertheless, Odaenathus showed no lack of respect toward Gallienus, for he sent him the satraps he captured though, as it seemed, merely for the purpose of insulting him and displaying his own prowess. (...) Odaenathus, besides, besieged an army of Parthians at Ctesiphon and devastated all the country round about, killing men without number. But when all the satraps from all the outlying regions flocked together to Ctesiphon for the purpose of common defence, there were long-lasting battles with varying results, but more long-lasting still was the success of the Romans. Moreover, since Odaenathus' sole purpose was to set Valerian free, he daily pressed onward, but this best of commanders, now on a foreign soil, suffered greatly because of the difficult ground" (English translation, ed. Loeb, David Magie). 
the Augustan time (the conditio of a new era). The message that was transmitted through the 'Power of Images' (to cite Zanker) included references to this revenge in the statue of Prima Porta, or Virgil's Aeneid, Horace's Carmen Saeculare, and Ovid's Fasti. ${ }^{36}$ More than a century later, Trajan became the first emperor to be (posthumously) named diuus Traianus Parthicus, and coin types support the idea that there was a representation of a statue in a chariot with the legend Triumphus Parthicus. It would have been impossible to stage a posthumous triumphus, but an aduentus of the image of a 'diuus Traianus Parthicus' may have been an adequate ceremony for Hadrian to celebrate his predecessor's victory and mark the return of his ashes. ${ }^{37}$ The Severan campaign against the Parthians was a decisive element of the new dynastic promotional programme, during the years $195^{-198}$. It allowed the new family to emphasis imperial continuity, which was celebrated by coins noting the laetitia temporum or the felicitas saeculi as well as the ceternitas imperii. The same themes were developed afterwards in association with the decennalia, Caracalla's wedding and the preparation of the ludi saeculares..$^{38}$ Making use of a recognised imperial discourse allowed the Severan principate to legitimize itself through close connection to the glorious past. Thus, a link to Trajan was made by celebrating the Severan victory over the Parthians in 198, and by associating this to the elevation to power of a son by his father (Caracalla by Septimius Severus). According to the Feriale Duranum, Trajan, the Parthian victor, became sole emperor on the 28 th of January 98 , exactly a century earlier. ${ }^{39}$

36 Cf. Paul Zanker, The Power of Images in the Age of Augustus (Ann Arbor 1988), 167-238, and Karl Galinsky, Augustan Culture. An Interpretive Introduction (Princeton 1996), 10-41. The links asserted there with the Auctoritas have been recently discussed by Gregory Rowe, 'Reconsidering the Auctoritas of Augustus', Journal of Roman Studies 103 (2013), 1-15.

37 Benoist 2005, op. cit. (n. 8), 236-239 (about the pseudo-triumphus Parthicus), and 150-156 (the distinction between funus and consecratio); contra Javier Arce, 'Muerte, consecratio y triumfo del emperador Trajano', in Julián González (ed.), Trajano emperador de Roma (Rome 200o), 55-69; and recently 'Roman imperial funerals in effigie', in Björn C. Ewald and Carlos F. Noreña (eds.), The Emperor and Rome. Space, Representation, and Ritual (Cambridge 2011), 309-324.

38 Benoist 2005, op. cit. (n. 8), 71-74 (about the adventus), 284-288 (the ludi saeculares), and $307-308$ (the Eternity theme with the coins of plate IIIb about Aeternitas under the Severan emperors).

39 Cf. Feriale Duranum, I, 14-16: (a.d.) V. K[a]l. [feb]rarias ob V[i]ctori[as--- et Parthica $]$ m Maxi/m[a]m diui Seue [ri e] tob [imperium diui Traiani uictoriae part] hic [a]e / b(ouem) $[f . d]$ iuo Traian [o b. m. For a brief presentation, Stéphane Benoist, 'Le Feriale Duranum', in Antoine Hermary and Bertrand Jaeger (eds.), Thesaurus Cultus et Rituum Antiquorum (ThesCRA), vir. Festivals and contests, III. "Fêtes et jeux dans le monde romain" (J. Paul Getty Museum, Los Angeles 2011), 226-229, with bibliographical references. 
In 26o, in contrast, the defeat of Valerian and his humiliating captivity were surely a symbolic night-mare, and a major disadvantage for his son Gallienus in maintaining his power and ensuring legitimacy. We should, in that perspective, consider Odaenathus' legatio ${ }^{40}$ as a sensible decision by an emperor who was confronted with a process of dissolution of the unity of his empire (from West to East, from the so-called Gallic empire to the Palmyrian kingdom).${ }^{41}$

The imperial discourse considers the conception of a territorial empire, such as the statio principis, as a double-mirror, which can be appropriated into a rhetoric construction about good and bad emperors. In the perspective of such a construction of a collective and personal identity, created from res gestae and personae, imperial titulatures can be analysed as a way to define the Imperium Romanum as a space; a process of transformation of territories by the Roman army or after diplomatic agreements; and as a means to think about a universal city embodied by its princeps. ${ }^{42} \mathrm{~A}$ few documents support the main arguments.

The first example may be useful to understand how the personal identification of emperors in standard formulations like legati Augusti pro praetore - of which there remain sixty cases within around two thousands inscriptionswas usually linked to special situations. ${ }^{43}$ These were the participation in

$40 \quad$ How should we understand this legatio? As an interpretatio Romana of a separate power or a real delegation by Gallienus of an Imperial authority? Cf. Stéphane Benoist, 'Le prince et la société romaine d'empire au ${ }_{\text {III }}{ }^{\mathrm{e}}$ siècle: le cas des ornamenta', Cahiers $d u$ Centre Gustave-Glotz 11 (2000), 309-329, using then recently discovered papyrological documentation, and the interpretation by David Potter of 'The Career of Odaenathus', in Prophecy and History in the Crisis of the Roman Empire. A Historical Commentary on the Thirteenth Sibylline Oracle (Oxford 1990), Appendix 4, 381-394.

41 A general overview of the context by Michel Christol, L'empire romain du III ${ }^{e}$ siècle. Histoire politique (192-325 après J.-C.) (Paris 1997), 139-162.

42 On the concept of an imperial discourse through epigraphic evidence, Stéphane Benoist forthcoming, op. cit. (n. 3).

$43 C I L$, III, 14387 d \& w; IGLS, 6, 2775, Heliopolis, Syria: tri] b(uno) mi[l(itum) leg(ionis) XIII Gem(inae), III uir(o) a (uro) a(rgento) a(ere)f(lando)f(eriundo), leg(ato)]/[prop]r(aetore) prou[inciae Cretae et Cyren(aicae), aedili] / [cur(uli) ?], praet(ori) p[eregr(ino) ?, leg(ato) Aug(usti) leg(ionis)XI Cl(audiae) p(iae)f(idelis), praepo]/[sit]o leg(ionis) IIII S[cyth(icae) b]ell[o Dac(ico) ---], / [le]g(ato) pro pr(aetore) pr[oui]nc[iae Iudaeae et leg(ionis) $X$ fret(ensis), ad]/[lect]o interc[omite]s Au[g(usti) exped(itione)Dacic(a)II ab Imp(eratore)]/ [Caes(are)] Nerua Traiano [Aug(usto) Germ(anico) Dacico Parthico, praeposi]/[to a] b eodem Imp(eratore) Parth[ico bello ---] / [et] donis militar(ibus) do[nato bis ?, leg(ato) 
military campaigns alongside the prince (as amicus or / and comes), the creation of new provinces, or control over $a d$ hoc associations of several provinces, diplomatic missions, etc. ${ }^{44}$ An anonymous cursus honorum from Heliopolis provides an excellent example of such close connections between emperors and legati, in this case during the successive campaigns of Trajan in Dacia and Parthia. ${ }^{45}$

The cognomina deuictarum gentium ${ }^{46}$ can be understood as a perception of what was considered 'becoming Roman' in the perspective of military campaigns and the ensuing process of provincialization. We can illustrate that process through the examples of Septimius Severus' and Julian's cognomina (Arabicus, Adiabenicus and Parthicus Maximus, Alamanicus Maximus, Francicus Maximus and Sarmaticus Maximus). ${ }^{47}$ One very interesting aspect

pro pr(aetore) Imp(eratoris) Caes(aris) Neruae] / [Tr]aiani Aug(usti) Germ(anici) Da[cici Parthici prouinciae Cappadociae et Galati]/[ae], item leg(ato) pro pr(aetore) eius[dem Imp(eratoris) Caes(aris) Neruae Traiani Aug(usti) prou(inciae)] / Syriae P[hoenices Commagenae huic senatus] / [c]ensuit m[aximo principe Imp(eratore) Caes(are) Nerua] / [Traiano Aug(usto) Germ(anico) Dacico Parthico auctore], / [statuam in foro Aug(usti) pecun (ia) publ(ica) ponendam].

44 Stéphane Benoist, 'Princeps et legati, de la conception impériale de la délégation de pouvoir. Nature, fonction, devenir, d'Auguste au IV ${ }^{\mathrm{e}}$ siècle de notre ère', in Agnès Bérenger and Frédérique Lachaud (eds.), Hiérarchie des pouvoirs, délégation de pouvoir et responsabilité des administrateurs dans l'Antiquité et au Moyen Âge (Metz 2012), 135-159, on the different circumstances which explain specific formulas (with an appendix of 60 inscriptions).

45 About the general context of the Trajanic Wars, see Julian Bennett, Trajan Optimus Princeps. A Life and Times (London 1997), esp. "Dacicus" and "Parthicus," 85-103 and 183-204, with endnotes 245-250 and 269-274; and Karl Strobel, Kaiser Traian. Eine Epoche der Weltgeschichte (Regensburg 2010), "Der Weg zum Feldherrnruhm," 218-303, and "Das Abenteuer des Partherkrieges," 348-398.

46 For a different perspective of the perpetual victory of emperors, Benoist 2005, op. cit. (n. 8), 255-265.

For Septimius Severus, $A E, 1993,1789=R M D$, III, 189: Imp(erator) Caes(ar) diui M(arci) Antonini Pii Germ(anici) Sarm(atici)f(ilius) diui / Commodi frater diui Antonini Pii nep(os) diui Hadriani / pronep(os) / diui Traiani Parth(ici) abnep(os) diui Neruae adnep(os) / L(ucius) Septimius Seuerus Pius Pertinax Aug(ustus), Arab(icus) Adiab(enicus) Par/ thic(us) max(imus), pontif(ex) max(imus), trib(unicia) potest(ate) XIIII, imp(erator) XIII, co(n)s(ul) III, p(ater) p(atriae), proco(n)s(ul), / Imp(erator) Caesar Luci Septimi Seueri Pii Pertin(acis) Aug(usti) Arab(ici) / Adiab(enici) Parth(ici) $\max ($ imi) f(ilius) diui M(arci) Antonini Pii Germ(anici) Sarm(atici) / nep(os) diui Antonini Pii pronep(os) diui Hadriani abnep(os) / diui Traiani Parth(ici) et diui Nervae adnep(os) / M(arcus) Aurellius Antoninus Pius Aug(ustus), tr(ibunicia) pot(estate) VIIII, co(n)s(ul) II, proco(nsul). // A(nte) d(iem)X $K($ alendas) Dec(embres) / Marso et Faustino co(n)s(ulibus) (22 november 206) / ex gregale / C(aio) Iulio Guratif(ilio) Domi/tiano Antioc(hia) ex Syr(ia) Coele / et Proculo f(ilio) eius / 
about our main focus of attention, the Parthian/Persian affairs, is the concomitant use of the cognomina Parthicus and Persicus during the 3rd century AD. In that period, it was possible to use those two cognomina in different perspectives: in memoriam of the glorious past embodied by the good emperors Trajan or Septimius Severus, and as a contemporary reference to present circumstances. From the 220's onwards, after all, Sassanids conquered power and became an aggressive enemy, which formed the main risk for the Roman Empire. ${ }^{48}$ A victory over the Persians, henceforth, could be celebrated as either a clear reference to Persian ethnical identity (i.e. the new dynastic power in charge of that region), or to recall past glory. A few decades later, Numerian's inscriptions should be reconsidered by analysing their use of Parthicus Maximus/Persicus Maximus in the forms. Perhaps we can even rehabilitate his reign, and especially his Persian campaign and the last fifteen months of Numerian's life, if we combine an African inscription, coins, a papyrus and a passage from Nemesianus' Cynegetics. ${ }^{49}$

The permanence of the imperial identity as expressed through references to the power of the princeps and the ways in which he was commemorated becomes clear from an example at the very end of our period of study, during the 4 th and the $5^{\text {th }}$ centuries $\mathrm{AD}$. Constantine was celebrated as the

descriptum et recognitum ex tabula ae/rea qu(a)e fixa est Rom(a)e in muro pos $(t)$ templum / diui Aug(usti) ad Mineruam. For Julian, $A E$, 1969/1970, 631 = 2000, 1503, Ma'ayan Barukh, $c f$. W. Eck, 'Zur Neulesung der Iulian-Inschrift von Ma'ayan Barukh', Chiron 30 (2000), 857859: $R[$ o $]$ mani orbis liberat $[o] / r[i]$, templorum $/[$ re $]$ stauratori, cur $/[$ ia $]$ rum et rei public/ $[a e]$ recreatori, bar/[ba]rorum extinctor $[i] / d$ (omino) $n$ (ostro) Iouliano / perpetuo Augusto / Alamannico maximo / Francico maximo / Sarmatico maximo, / [p]ontifici maximo, pa/tri patriae, Foenicum / genus, ob imperi[um] / [eius uota...].

48 Christol 1997, op. cit. (n. 41), has chosen the Sasanids' establishment as a turning point for his history of the 3rd century AD: 2nd part "La puissance de Rome à l'épreuve (226249)," esp. 73-75 and 111 (notes); and Potter 1990, op. cit. (n. 40), "Appendix III: Alexander Severus and Ardashir," 370-380, previously published in Mesopotamia 22 (1987), 147-157, with minor differences.

49 See the convincing arguments about different documents by Xavier Dupuis, 'L'empereur Numérien Germanicus maximus Gothicus maximus sur un milliaire du Sud tunisien', Cahiers de Centre Gustave-Glotz 25 (2014), 263-279, within the acts of the colloquium of the French Society of Roman Epigraphy SFER [Paris 8 June 2013], about "Épigraphie et discours impérial: mettre en scène les mots pour le dire"): a milestone (Jules Toutain, 'Les nouveaux milliaires de la route de Capsa à Tacape découverts par M. le capitaine Donau', MSAF 64 (1905), 153-230, no. 33; Pierre Salama, 'Anomalies et aberrations rencontrées sur des inscriptions milliaires de la voie romaine Ammaedara-Capsa-Tacapes', ZPE 149 (2004), 245-255, at 246-247 with Fig. 2 et 3 page 255) and Nemesianus, Cynegetics $63-71$, for the main evidence about this peculiar commemoration of imperial victories. 
Maximus uictor (after he had abandoned the title inuictus) ac triumfator semper Augustus. ${ }^{50} \mathrm{He}$ was, as far as we trust the evidence, the first emperor with nine cognomina: Germanicus, Armeniacus and Medicus Maximus, as well as Sarmaticus Maximus, Arabicus Maximus and Persicus Maximus, and finally Britannicus Maximus, Carpicus Maximus and Gothicus Maximus. ${ }^{51}$ For Julian, the fundamental link between the emperor, the Imperium Romanum as a territory, and the 'Others', is acutely expressed in a Palestinian text: the emperor is celebrated as the Romani orbis liberator, the barbarorum extinctor and a perpetuus Augustus. ${ }^{52}$ The princeps is naturally the protector of the empire and its inhabitants, and, in doing so, he has to reply to any request. In this he was like he was described in the adsertio of the magister militum Orientis Anatolius in $438 \mathrm{AD}$, who considered that soldiers should not be disturbed by civilian accusations. Theodosius II responded to the praefectus praetorio Orientis Florentius in a mostly rhetorical answer about those limitanei milites (in extrema parte Romani saeculi), whose life was difficult and whose duty towards the Res publica was essential, even if the Sassanid threat was real but the direct conflicts between Romans and Persians very rare under this reign. ${ }^{53}$

5o $A E, 1975,785 \mathrm{~d}=A E, 1961,26 \mathrm{~b}$, Yornus (Pontus et Bithynia): $\operatorname{Impe}[$ ratori Ca $]$ es(ari) $/ F l($ auio) Val(erio) C [onst] antino / maximo uictor $(i) /$ ac triumfator $(i) /$ semper Aug $($ usto $) /$ et $F l($ auio) Cl(audio) Constantino / et Fl(auio) Iul(io) Constantio / et Fl(auio) Iul(io) Constantae (!) / [nobbb(ilissimis tribus) Caesss(aribus tribus)].

51 About Constantine's titulature, Stéphane Benoist, 'La statio principis de l'empereur Constantin: figure augustéenne ou prince révolutionnaire?', in Josep Villela Masana (ed), Constantinus. ¿El primer emperador cristiano? Religión y política en el siglo IV, BarcelonaTarragona 20-24 de marzo de 2012 (Barcelone 2015), 325-336. For an inventory of the different cognomina deuictarum gentium, Benoist 2005, op. cit. (n. 8), 257-258.

52 Cf. Stéphane Benoist, 'Identité du prince et discours impérial: le cas de Julien', Antiquité tardive 17 (2009) [2010], 109-117.

53 Nov. Theod. 4, Feb. 25, 438: (...) ne libeat audacibus exercere litigia, ut liceat nostris militibus otiari, quos in extrema parte Romani saeculi sacramentorum legibus amandatos calumnia latentes inuenit? Quamobrem, Florenti parens karissime atque amantissime, inlustris et magnifica auctoritas tua, quae statuta maiestatis augustae cura peruigili et congruo semper fine conclusit, nunc etiam edictis propositis ad omnium notitiam faciat peruenire. "We must hope, that it will not please the audacious to employ litigation, and thus Our soldiers may be allowed to be at ease, although calumny finds them in obscurity in the farthest parts of the Roman Empire where they have been assigned by the regulations of their military oaths of service. Wherefore, O Florentius, dearest and most beloved Father, since Your Illustrious and Magnificent Authority always consummates the statutes of Our August Majesty with watchful care and with a suitable execution, you shall now also by posting edicts cause them to come to the knowledge of all." (trans. Clyde Pharr, The Theodosian Code and Novels and the Sirmondian Constitutions [Princeton, 1952]). Cf. Fergus Millar, 
The main argument developed above about a Roman imperial discourse, and the identity of the Roman Empire and its princeps through the perception of Others in a few documents from Augustus to Theodosius II, is essentially dependent on 'Roman' evidence, even if there is some evidence for neighbours' voices, e.g. Parthian ones. This is why this paper now ends with reference to a last piece of evidence, the Inscription of Shapur I at Naqsh-e Rustam, near Persepolis. I am, by no means, a specialist of medium-Persian or Parthian languages. My knowledge is based on secondary literature, from André Maricq to Richard Frye or Philip Huyse. ${ }^{54} \mathrm{~A}$ few years ago regular seminars about the 3rd century AD were held at the Sorbonne (Centre Gustave-Glotz). In these seminars, the late Xavier Loriot and Philip Huyse proposed a very interesting form of communication, combining two voices from two different perspectives: Roman history and Persian philology and linguistic, about the Roman contingents during the third Sasanid campaign against Valerian. ${ }^{55}$

A Greek Roman Empire: Power and Belief under Theodosius II (408-450), Sather Classical Lectures 64, (Berkeley 2006), 75-76, about security and insecurity in a section dealing with "the Eastern Frontier: Sasanids and Saracens.".

54 The title Res Gestae was first conferred by Michael Rostovtzeff in his paper published in 1943: 'Res Gestae Divi Saporis and Daru', Berytus 8 (1943), 17-6o. From Maricq's edition to the monumental one by Philip Huyse who provided the last comprehensive edition of the text in the Corpus Inscriptionum Iranicarum, after Richard Frye's translation of the first part of the text in an appendix of his History of Ancient Iran: André Maricq, 'Res Gestae Divi Saporis', Syria 35 (1958), 295-36o = Classica et orientalia (Paris 1965), 37-101; Philip Huyse, Die dreisprachige Inschrift Šäbuhrs I. an der Ka'ba-I Zardušt (̌̌KK), Corpus Inscriptionum Iranicarum, III. Pahlavi Inscriptions, I. Royal Inscriptions (London 1999), and Richard N. Frye, The history of Ancient Iran (Munich 1983), "Appendix 4," 371-372. About the interpretation of the text within the relations between Romans and Persians, from our "Roman evidence" - e.g. Dio to Ammianus Marcellinus, see above n. 24 the mention of the correspondence between Constance and Shapur II-, the accurate analysis by Erich Kettenhoffen, 'Die Einforderung des Achämenidenerbes durch Ardašīr: Eine interpretatio romana, Orientalia Lovaniensia Periodica 15 (1984), 177-19o: Saphur I is by no means a "Cyrus redivivus!" For a complete overview of our evidence about the RomanoParthian war: Id., Die römisch-persischen Kriege des 3. Jahrhunderts n. Chr. Nach der Inschrift Šāhpuhrs I an der Ka'be-ye Zartošt (ك̌KZ) (Wiesbaden 1982).

55 Xavier Loriot and Philip Huyse, 'Commentaire à deux voix de l'inscription dite Res Gestae Divi Saporis', in Marie-Henriette Quet (ed.), La 'crise' de l'empire romain de Marc Aurèle à Constantin (Paris 2006), 307-344: Huyse, "Les provinces romaines dans la grande inscription trilingue de Šābuhr I ${ }^{\text {er }}$ sur la Ka'ba-ye Zardošt," 308-327; Loriot, "Les contingents de l'armée de Valérien," 328-344. 
Two brief remarks to conclude. Firstly, this so-called Res Gestae diui Saporis, - the name of which is surely a miscomprehension of the document, ${ }^{56}$ even if the inscription, post-Maricq, has been seen as a kind of 3rd-century parallel of the RGDA, - is essential to understand the Persian version of Valerian's defeat in 260. It gives a precise description of the Persian Empire, beginning with a complete list of lands under the rule of Shapur $(\breve{s} K Z$ I $§ 2-5)$. Then, it mentions the three Roman emperors, Gordian III, Philip and Valerian, and their "deeds" related to Persia (maybe there is some sort of irony in the presentation of those events) ( $\check{K K Z}$ I $\S 6-30$ ). This monumentum can be understood as a triumphal assertion about an empire, its ruler, and his actions under the protection of Mazda. ${ }^{57}$ If we want to propose a true Roman parallel, the same elements of self-confidence in an ever glorious power can be found in the triumphal ceremonies at Rome: processions of the armies, tituli and pictures to tell the story of the campaigns and statues to celebrate the permanent victor (even if the laudationes funebres could be interpreted in the same framework). These ceremonies formed a more comprehensive exhibition, combining words, rituals and monuments.

Secondly, the elements of the Roman imperial discourse which this paper discusses, from the RGDA and various imperial titulatures to literary texts, all incorporate references to enemies to formulate the princeps' identity. They belonged to a set of notions which together shaped the Roman imperial res publica. We can assume that some of those texts pertained to political rituals,

$5^{6}$ For example, Leo Truempelmann, 'Sasanian Rock-Reliefs', Mesopotamia 22 (1987), 337-340, who concluded his short paper by this final remark: "To sum up: The Sasanian reliefs within the enclosure-wall at Nagh-I Rustam were not to be seen by the public. They were not means of propaganda but were the grave-monuments of the respective kings and showed what the prominent achievement in the live of the king had been. It was for their soul and name-preservation that the reliefs had been made." Contra Zeev Rubin, 'The Roman Empire in the Res Gestae Divi Saporis. The Mediterranean World in Sāsānian Propaganda', in Edouard Dąbrowa (ed.), Ancient Iran and the Mediterranean World. Proceedings of an international conference in honour of Professor Józef Wolski held at the Jagiellonian University, Cracow, in September 1996, (Cracow 1998), 177-185.

57 The status of the Greek text of the trilingual inscription remains a real debate between specialists: for example, the Appendix of Zeev Rubin's paper, 'Res Gestae Divi Saporis: Greek and Middle Iranian in a Document of Sasanian, anti-Roman Propaganda', in J.N. Adams, Mark Janse and Simon Swain (eds.), Bilinguism in Ancient Society. Language Contact and the Written Text (Oxford 2002), 267-297, "The Problem of the Genesis of the Greek Text," 291-297 is a response to Huyse's edition of the šKZ (1999, op. cit. n. 54), whose own 2006 paper (op. cit. n. 55) considers the use of three languages as a way to "universaliser les paroles du roi dans les langues vernaculaires de l'époque (at page 322)." 
which were supposed to define the empire and its ruler through collective commemoration: Tiberius in the Senate reading the Res Gestae of his father, publicly formulating an account that defined the political agenda, and the nature of the statio principis; or any emperor responding to petitions in his chancellery. The Principate needed to find a public expression that could be accepted by the SPQR. The discourse in which 'Others' figured prominentlyor in which their image was reconstructed - was essential to define the nature of the Principate. ${ }^{58}$

$5^{8}$ I am very grateful to Mike Peachin and Olivier Hekster for improving my arguments and my English text, at various steps. 
PART 2

Politics, Economics, \& Society 



\title{
Turning the Inside Out: The Divergent Experiences of Gaul and Africa during the Third Century AD
}

\author{
Dan Hoyer
}

\section{1 \\ Introduction}

The organizers of the conference ${ }^{1}$ from which the papers in this volume were drawn, 'Rome and the Worlds Beyond Roman Frontiers,' asked participants to focus on the interaction between people within Rome's borders, or the Roman world generally, and those outside of it. The papers included in this volume attest to the significance of this topic. There is, however, an inherent problem with the way the topic is framed; it is not always clear what groups of people we should consider as 'insiders' to the Roman world and what groups 'outsiders,' and how to interpret changes in the status of a particular group. Is this meant in terms of political integration? Military turmoil? Social or cultural unity? This issue is especially acute for the mid-third century $\mathrm{AD}$, a tumultuous and still poorly understood time when the Roman Empire experienced nearly constant warfare against both civil and foreign enemies, devastating plagues, a long series of claimants to the imperial throne, as well as many instances of political, military, and economic dislocations. These dislocations belie a simple picture of a Roman world versus groups of non-Roman others or 'outsiders,' as the civil warfare and the great number of different claimants to the supreme power who came forward during this period challenged the allegiances of Roman citizens, calling into question what it meant to be 'inside' or 'outside' the Empire.

In one case, that of northwestern Europe in the AD 26os, the problems of the period led to the rise of the Gallic emperor Postumus, a successful military leader who exercised authority over a large tract of territory that had once been an integral part of the previously united Roman Empire. During Postumus' rule, Rome was truly a fractured state, with Europe turned into a battleground between the legitimate, 'insider' emperor and senate at Rome

1 I would to thank the conference organizers for inviting me to present my work. I would also like to thank Mike Peachin and Inger Kuin for their very helpful comments on earlier drafts of this article, as well as the other conference participants who offered valuable feedback. 
and the breakaway, 'outsider' Empire ruled by Postumus, defining 'outsider' in terms of political integration. Yet, in many ways Postumus' reign did not encompass a complete break from the traditions and institutions of imperial Roman life and in several important respects the Gallic Empire continued to function as a typical Roman region; an 'insider' regime, at least from a social, cultural, and ideological sense. Other regions of the western Roman Empire, contrarily, experienced the period very differently from Gaul. For instance, the Roman holdings in North Africa were never truly politically 'outside' of the central imperial authority in the way that parts of northwestern Europe were under Postumus. Roman Africa likewise remained a socially, culturally, and ideologically 'insider' area throughout this time. Yet, the region was certainly affected by the period's many troubles and did experience dislocations of traditional rule in certain areas; in terms of civil warfare and the rise of nontraditional authority figures, North Africa was as 'outside' as any other region in the western Empire.

The main point to take away from this is that neither of these regions allow for any simple categorization of Roman versus non-Roman, of 'outsider' versus 'insider;' both areas experienced military turmoil and political dislocation and both retained certain important traditional Roman institutions. The histories of these different parts of the western Empire during the mid-third century are, however, quite distinct. Since these differences cannot be explained merely by appeal to political and military fracturing, or the 'outsideness' of one region compared to the other, another approach must be sought.

In this article, then, I explore the problem of Roman cohesiveness during the mid-third century AD by looking at how these two very different regions were affected by the problems of the period. By taking a long view of the period, stretching back into the late second century $\mathrm{AD}$, and by comparing the regions along several key factors, namely political, ideological, military, economic, and financial, ${ }^{2}$ it becomes clear that the two areas emerged from the late Antonine and Severan periods following very different paths. After a brief

2 The focus on these factors is supported by theoretical work in sociology, notably Mann's theory about the sources of political power, known as the IEMP model. The basic formulation of Mann's theory is that “[a] general account of societies, their structure, and their history can best be given in terms of the interrelations of what I will call the four sources of social power: ideological, economic, military, and political (IEMP) relationships." Michael Mann, The Sources of Social Power, vol. I. (Cambridge, 1986), 2. Similarly, in recent years Turchin has advocated the need to explore the deep roots of important political and social developments in order to properly delineate long-term historical processes, terming this endeavor Cliodynamics. Peter Turchin, "Toward Cliodynamics - an Analytical, Predictive Science of History," Cliodynamics 2/1 (2011). 
summary of the current state of scholarship on the history of the third century $\mathrm{AD}$, I then proceed to give an account of how each of the factors noted above developed over the course of the imperial period and how this affected the two regions under investigation here. In each of the following sections, I discuss first the interesting case of Postumus, then jump back in time to discuss the events of $\mathrm{AD} 238$, pointing out the similarities and differences with the experience of Postumus' Imperium Galliarum. The cases are presented out of chronological order, since Postumus' experience represents perhaps the pinnacle of the third century turmoil and presents a relatively clear account of the complex negotiation of political, social, and economic power in which Roman rulers were forced to engage during this period. Treating the events that transpired in Africa in AD 238 second offers a sharper contrast, and allows for a more forceful argument about the key differences between the two cases.

The main thrust of this article is to make an explicit comparison between Gaul and Africa in order to illustrate clearly the importance of these key factors on the regions' divergent experiences during one of the most momentous and turbulent periods in the history of the Roman Empire. I conclude with the observation that analyzing these historical events in terms of where groups of people stand in relation to the Roman world, whether they ought to be treated as 'outsiders' or 'insiders,' fails to do proper justice to the true complexity of the situation. I argue that, rather, it is important to understand the long-term structural developments, which affected particular historical outcomes and to recognize that different facets of a society can progress along different paths, meaning that these regions at once existed both 'inside' and 'outside' of the traditional structures of the Roman Empire.

The notion that the third century AD was a time of crisis, when the stability and prosperity of the High Roman Empire were suddenly undermined by barbarian invasions, disease, civil warfare, and financial ruin, has long featured prominently in analyses of the later Roman Empire. ${ }^{3}$ This crisis has traditionally been seen as an all-encompassing decline in Roman civilization which began at the end of the Severan dynasty in AD 235 and which ultimately led,

3 A useful and recent survey of this notion in modern scholarship is provided by Wolf Liebeschuetz, "Was There a Crisis of the Third Century?," in Crises and the Roman Empire: Proceedings of the Seventh Workshop of the International Network Impact of Empire, Nijmegen, June 20-24, 2006 Olivier Hekster, Gerda de Kleijn, and Daniëlle Slootjes (Leiden, 2007), 11-20. 
with perhaps a brief recovery in the early fourth century, to the collapse of the Roman state and the onset of the Medieval period. ${ }^{4}$ In more recent years, however, the idea that there was a crisis at all has been questioned. Some scholars have gone so far as to suggest that crisis is an inadequate description of this period, preferring terms like transformation and change. ${ }^{5}$ Others, notably Witschel, argue that there was no single, Empire-wide crisis, rather a series of isolated and regionally specific problems, such as disease in the Eastern Mediterranean and military threats along the northern frontiers, while other areas actually experienced a period of prosperity. ${ }^{6}$ Le Glay, similarly, contends that the events of the third century need to be considered not only with an eye to regional differences, but also along separate lines of inquiry; political stability, the military situation, changing social structures, economic activity, etc. ${ }^{7}$

Although there is still no consensus on how to describe the period, it is undeniable that in at least some parts of the Roman world, certain fundamental changes were occurring during this time. One of the clearest and most damaging changes during the mid-third century was the rise of the so-called

4 Edward Gibbon, The Decline and Fall of the Roman Empire, ed. Hans-Friedrich Müeller (New York, 2003), pp. 58-212; Michael Ivanovitch Rostovtzeff, The Social and Economic History of the Roman Empire, ed. Peter M. Fraser (Oxford, 1998), pp. 469-501. Georges Depeyrot, "Crise économique, formation des prix, et politique monétaire au troisième siècle après J.-C.," Histoire \& Mesure 3/2 (1988), 235-47. Géza Alföldy, Die Krise des Römischen Reiches: Geschichte, Geschichtsschreibung, und Geschichtsbetrachtung: ausgewählte Beiträge (Stuttgart, 1989), pp. 464-90. Dominique Hollard, "La circulation monétaire en Gaul au III siècle après J.-C," in Coin Finds and Coin Use in the Roman World, ed. Cathy E. King and David G. Wigg (Berlin, 1996), 203-17. Ramsay MacMullen, Roman Government's Response to Crisis, A.D. 235-337 (New Haven, 1976), pp. 195-213. Jean-Michel Carrié, "Solidus et credit: qu'est-ce que l'or a pu changer?," in Credito e moneta nel mondo romano: atti degli Incontri capresi di storia dell'economia antica : Capri, 12-14 ottobre 20oo, ed. Elio Lo Cascio (Bari, 2003), 265-79 likewise describe the many crises faced by Rome during the third century, but focus instead on how these crises were overcome under the Tetrarchy.

5 A recent and important example is David S. Potter, The Roman Empire at Bay: AD 180-395 (London, 2004), pp. 263-98.

6 Christian Witschel, Krise, Rezession, Stagnation?: Der Westen Des Römischen Reiches Im 3. Jahrhundert N. Chr (Frankfurt, 1999), pp. 375-7. cf. Lukas de Blois, "The Military Factor in the Onset of Crises in the Roman Empire in the Third Century AD," in The impact of the Roman army (200 BC-AD 476), economic, social, political, religious, and cultural aspects : proceedings of the Sixth Workshop of the International Network Impact of Empire (Roman Empire, 200 B.C.-A.D. 476), Capri, March 29-April 2, 2005, ed. Lukas de Blois et al. (Leiden, 2007), 497507 . De Blois follows Witschel's model of regionalism in describing the increasingly disruptive crises during the period AD 230 to 284 .

7 Marcel Le Glay, Grandeur et chute de l'Empire (Paris, 2005), pp. 251-2. 
Soldatenkaiser; ${ }^{8}$ popular and successful Roman military leaders who aspired to rule the Roman world and who used their control of groups of soldiers to claim, often only briefly, the ultimate power in Rome. The prevalence of these soldier-emperors, who held the reigns of power essentially from the death of Severus Alexander in AD 235 until Aurelian's reunification of the Empire thirty-nine years later, had serious consequences on Rome's political and military fabric. The constant series of usurpers and claimants to the seat of power in Rome challenged, or at least problematized, the way in which the entire Empire was ruled, leading to outright civil warfare and political fragmentation. Yet, although such troubles were certainly felt Empire-wide, the fragmentation of central Roman authority must also be explored with an eye towards regional differences. Specifically, as I argue in this paper, regional differences in three of the key elements of Roman life-military activity, economic productivity, and financial stability - caused the regions of the western Empire to react differently to the political and ideological problems afflicting Rome during this time.

The most fruitful avenue to test this hypothesis and to illuminate the exact impact that each of the above-mentioned factors had on the Roman world is through direct comparison between different regions. I offer in this paper, then, a brief look at two important episodes of the third century AD: the so-called 'Gallic Empire' of Postumus and his successors, lasting from AD 260 to 274, and the events of the year AD 238 in North Africa which saw the ascension to the throne of Gordian I as well as the short-lived revolt of Capellianus, praetorian legate of Numidia. These moments of instability in the two regions were similar in several respects. They both involved political and military upheaval as well as civil fighting instigated by popular local leaders, and both regions also saw some continuity in certain important institutions such as with the maintenance of the symbols of authority and of administrative offices. Yet, in spite of having similar beginnings, the effects of these political and military upheavals in Gaul were significantly more intense and long lasting than those in Africa.

In other words, both regions suffered from the problems of the period and both regions were able to maintain continuity in certain aspects of Roman life, although Gaul experienced a political, military, and economic break from the rest of the Empire in ways that Africa never did. The crucial question, then, is what caused this difference? This is the question I explore in depth in the

8 These are the 'barracks' or 'soldier' emperors; short lived rulers during the mid-third century who mainly came from relatively low-ranking military positions to claim the emperorship. Not all emperors during this period, though, fit this description and the term used here is meant simply to denote the chaotic period in which numerous claimants to ultimate power came forward backed by factions of the Roman military. 
remainder of the article, highlighting the political, ideological, military, economic, and financial elements as some of the essential factors in how the two episodes unfolded over the course of the third century AD. In answering this question, I posit that the disruptions which ultimately led to the rise of the Gallic Empire as well as Africa's remarkable stability during the period both had deep, long-term structural roots. Moreover, I contend that the complexity and diversity of the regions' experiences during this time belie any simple categorization of either case as being 'outside' or 'inside' the Roman Empire.

Before exploring the different factors that shaped the way the different regions reacted to this period of turmoil, it is necessary to provide an overview of the actions and events that occurred in northwestern Europe in the AD 260 s along with those from Africa in AD 238, focusing on how the stability of Roman political life was disrupted in the different regions. First, a look at the period from roughly AD 260 to AD 274 when much of Rome's territory in northwestern Europe fell under the authority of Marcus Cassianius Latinius Postumus.

The precise timeline of events is still debated, but, simply put, in AD 258 Postumus, as governor of Lower Germany, participated in the defeat of an invading Barbarian tribe, the Iuthungi, led by the emperor Valerian's son Gallienus. According to Zosimus, ${ }^{9}$ Postumus was very generous rewarding his soldiers with booty after the victory, but the Praetorian Prefect, a certain Silvanus, took much of this booty away. The troops then revolted, besieged and captured Cologne, killed Silvanus and hailed Postumus emperor. ${ }^{10}$ Postumus quickly consolidated his power, taking control of all the armies in Gaul and Germany and, by AD 261, extending his authority into parts of Spain as well as Britain. ${ }^{11}$ The area under his rule, termed the Imperium Galliarum, was thus comprised of what had been several of Rome's provinces in northern Europe,

$9 \quad$ Zosimus 1.38.2.

10 The most comprehensive account of this period remains John F. Drinkwater, The Gallic Empire Separatism and Continuity in the North-Western Provinces of the Roman Empire, A.D. 26o-274 (Stuttgart, 1987). For useful, more recent summaries of the events, see Potter, The Roman Empire at Bay; Andreas Luther, "Das Gallische Sonderreich," in Die Zeit Der Soldatenkaiser: Krise Und Transformation Des Römischen Reiches Im 3. Jahrhundert N. Chr. (235-284), ed. Klaus-Peter Johne, Udo Hartmann, and Thomas Gerhardt (Leiden: Brill, 2008), 11-20.

11 Luther, “Das Gallische Sonderreich," p. 329. 
eleven at the height of the Empire. ${ }^{12}$ The security of the Gallic Empire as an entity distinct from the central Roman state was not, however, entirely unchallenged. Postumus was forced to repel a major attack led by Gallienus, the central Roman emperor, in an attempt to reclaim the Gallic territory for Rome in AD $26.5^{13}$ Then in AD 269, after Postumus was murdered by his own troops, the next central Roman emperor, Claudius II Gothicus, was able to wrest Postumus' Spanish holdings away from the Gallic Empire. Claudius, however, was unable to capitalize on his victory or on Gaul's internal turmoil at the time and the Imperium Galliarum remained largely intact under the Gallic emperors Marius, Victorianus, and the two Tetrici. ${ }^{14}$ The Imperium Galliarum, thus, existed in effect as an independent entity separate from, or 'outside' of, the central Roman state until the defeat of Tetricus I and II, the last of the Gallic emperors, by Aurelian in AD $274 \cdot{ }^{15}$

This episode at first glance appears rather unremarkable in the context of the western Empire during the third century AD: a successful and popular military leader is hailed emperor by his troops after a successful campaign against foreign enemies, leading to some regional civil fighting. By this reading, Postumus was simply one in a line of so-called Soldatenkaiser; perhaps more successful than most others, but functioning in the same way as other usurpers of the period such as Maximinus, Decius, Aemilianus, and Hostilian, generals who briefly rose to power during the mid-third century and who had to constantly fight against other claimants to the throne. ${ }^{16}$ Yet, in certain ways

12 Werner Eck, "Das Gallische Sonderreich: Eine Einführung zum Stand der Forschung," in Die Krise des 3. Jahrhunderts n. Chr. und das Gallische Sonderreich: Akten des interdisziplinären Kolloquiums Xanten 26. bis 28. Februar 2009, ed. Thomas Fisher (Wiesbaden, 2012), 63-84.

13 Ingemar König, Die gallischen Usurpatoren von Postumus bis Tetricus (München, 1981), pp. 125-31. Drinkwater, The Gallic Empire Separatism and Continuity in the North-Western Provinces of the Roman Empire, A.D. 260-274, pp. 30-4. Potter, The Roman Empire at Bay, p. 263. Andreas Goltz and Udo Hartmann, "Velerianus und Gallienus," in Die Zeit Der Soldatenkaiser: Krise Und Transformation Des Römischen Reiches Im 3. Jahrhundert N. Chr. (235-284), ed. Klaus-Peter Johne, Udo Hartmann, and Thomas Gerhardt (Leiden, 2008), 223-96, pp. 287-92. Eck, "Das Gallische Sonderreich," p. 68.

14 König, Die gallischen Usurpatoren von Postumus bis Tetricus, pp. 148-52. Potter, The Roman Empire at Bay, p. 266.

15 Potter, The Roman Empire at Bay, p. 263 describes the Roman world as "fractured into three parts" during the latter parts of the third century, with the Palmyrene Empire of Odaenathus and his descendants having a similar rupturing effect on the Roman Empire as the Imperium Galliarum.

16 Notably Drinkwater, The Gallic Empire Separatism and Continuity in the North-Western Provinces of the Roman Empire, A.D. 26o-274, pp. 240-8. Andreas Johne, Klaus-Peter, Udo 
Postumus does not belong with the other imperial claimants of the period. As Eck recently remarked, Postumus' usurpation of power was much more durable than others', his rule circumscribed the authority of the central Roman state to a greater degree, and he was able to establish a dynastic succession, albeit short-lived, which almost no other usurper could do. ${ }^{17}$ There is a reason, after all, that most modern scholars term Postumus the emperor of his own territory, the Imperium Galliarum, a distinction not bestowed on the other usurper-emperors.

There has, however, been a great deal of scholarly debate about the Gallic Empire, particularly concerning the exact timeline of events, the motivations behind Postumus' actions, and the precise nature of his rule. ${ }^{18}$ Much of the controversy has surrounded the issue of whether Postumus was always content to rule over a circumscribed territory in the northwest part of the Empire, or whether he or his successors intend to invade Italy and rule over a unified Empire but were, for various reasons, simply prevented from doing so. ${ }^{19}$ This question of intent seems to me not only impossible to recover from the available sources, but largely to miss the point. Whatever Postumus or any of the other Gallic emperors wanted to do, the historical fact remains that their authority was exercised over a limited, circumscribed area carved out of the formerly unified Roman Empire. The important questions to be asked, then, are through what mechanisms Postumus consolidated his rule and, relatedly, to what extent was the Imperium Galliarum separate from, or 'outside' of, the rest of the Roman world?

Hartmann, and Thomas Gerhardt, "Einleitung," in Die Zeit Der Soldatenkaiser : Krise Und Transformation Des Römischen Reiches Im 3.Jahrhundert N. Chr. (235-284), ed. Klaus-Peter Johne, Udo Hartmann, and Thomas Gerhardt (Leiden, 2008), 5-12. Luther, "Das Gallische Sonderreich," pp. 340-1. See also de Blois, "The Military Factor in the Onset of Crises in the Roman Empire in the Third Century AD" on the specific role played by the military in the problems of the third century.

17 Eck, "Das Gallische Sonderreich," pp. 63-70.

18 See notably Karlheinz Dietz, Senatus contra principem: Untersuchungen zur senatorischen Opposition gegen Kaiser Maximinus Thrax (München, 1980). König, Die gallischen Usurpatoren von Postumus bis Tetricus. Drinkwater, The Gallic Empire Separatism and Continuity in the North-Western Provinces of the Roman Empire, A.D. 260-274. Potter, The Roman Empire at Bay. Luther, "Das Gallische Sonderreich." Eck, "Das Gallische Sonderreich."

19 Notable proponents of the former view are Drinkwater, The Gallic Empire Separatism and Continuity in the North-Western Provinces of the Roman Empire, A.D. 260-274. Potter, The Roman Empire at Bay. For the opposite view, see especially Eck, "Das Gallische Sonderreich." 
In terms of trying to determine the nature of Postumus' rule, it is, as has often been pointed out, very difficult to recover the exact nature and history of the Gallic Empire from the available sources. As far as can be reconstructed, however, it seems fairly clear that Postumus' authority was based on his control of the many Roman soldiers who had been situated in the northwestern part of the Empire from the late second century AD, when the Empire's German borders fell under serious threat. There were also many wealthy senatorial families living in Gaul at the time, and Postumus seems to have relied heavily on their wealth and power to fund and legitimate his rule. ${ }^{20}$ Another key aspect of Postumus' policy was that he maintained several of the ideological and political traditions of previous Roman emperors. ${ }^{21}$ This is demonstrated clearly by some of the material evidence that has survived from his rule.

Firstly, in inscriptions Postumus was addressed using the normal imperial titulature, being hailed as Imperator Caesar Marcus Cassianius Latinius Postumus Pius Felix Invictus Augustus Germanicus. ${ }^{22}$ Similarly, on coins, which are probably the best evidence we possess concerning the Gallic Empire, Postumus is labeled on the obverse as $\operatorname{Imp}$ (erator) $C$ (aesar), immediately identifying him as a typical, traditional Roman emperor. Likewise, on the reverses of these coins, Postumus is termed variously as Rest(itutor) Orbis (Restorer of the world), Pacator Orbis (Pacifier of the Globe), and Uberitas Aug(usti) (Wealthy/ Fortunate emperor), ${ }^{23}$ placing Postumus in the traditional role of a caring and helpful emperor, ensuring the unity of the whole world and maintaining the wealth and prosperity of his subjects, the Roman people. Moreover, it is clear from both the epigraphic and numismatic evidence that Postumus and his successors retained many of the offices typical of Roman imperial administration,

20 Kenneth W. Harl, Coinage in the Roman Economy, 30o B.C. to A.D. 700 (Baltimore, 1996), p. 145. Potter, The Roman Empire at Bay, p. 261.

21 Potter, The Roman Empire at Bay, p. 26o. Eck, "Das Gallische Sonderreich," pp. 66-74.

22 For instance, CIL 2.4943 (=ILS 562), a milestone from Acci in Spain.

23 For the coin types issued by the Gallic emperors, see the Roman Imperial Coinage vol. 5 part 2. See also notably Pierre Bastien, "La trouvaille de Guiscard (monnaies de bronze de Postume)," Revue numismatique 6/4 (1962), 232-36. Edward Besly and Roger Bland, The Cunetio Treasure: Roman Coinage of the Third Century AD (London, 1983). Drinkwater, The Gallic Empire Separatism and Continuity in the North-Western Provinces of the Roman Empire, A.D. 260-274, pp. 135-214. More recently, Daniel Gricourt and Dominique Hollard, "Les productions monétaires de Postume en 268-269 et celles de Lélien (269). Nouvelles propositions," The Numismatic Chronicle 170 (2010), 129-204. 
including consuls, governors, tribunes, pontifices, censors, and legates, and even continued to use consular dating on inscriptions. ${ }^{24}$

Further, just as Postumus is hailed in inscriptions using the traditional imperial titulature, these same inscriptions make it clear that he was imperator of something not quite the same as the old Roman Empire. An inscription found in Augsburg in Germany dating to AD 26o, for instance, records a dedication by an elite Roman of equestrian rank, a virperfectissimus named Marcus Simplicinius Genialis, recording the year with the formula "Imp(eratore) $d$ (omino) $n$ (ostro) [Postumo Au]g(usto) et [Honoratiano consulibus] (when our lord, the emperor Postumus Augustus, and Honoratianus were consuls)."25 This inscription illustrates that, regardless of whether or not Postumus intended to eventually rule over the entire territory that had once belonged to the Roman Empire, there is no doubt that the 'our' in Marcus Simplicinius' dedication referred exclusively to the people in those parts of Europe where Postumus was recognized as the emperor. Crucially, this excluded those who still regarded Gallienus the true, legitimate Roman ruler.

Similarly, although some of the legends on the reverses of Postumus' coins seek to identify him as a traditional Roman ruler, other types present the opposite message. He is referred to on certain coin issues as Salus Provinciarum (Savior of the Provinces) and Rest(itutor) Galliar(um) (Restorer of the Gallic [territory]), among other commemorations. The different reverse types featured on the Gallic coinage thus highlight Postumus' unique dual role as both typical Roman emperor who unites the whole world and ensures wealth and prosperity for his subjects, but also as the chief authority responsible for the safety and cohesion of the specific provinces under his control, namely the Imperium Galliarum. The implied counterpoint to Postumus as defender of the Gallic territory, of course, are those from whom the Imperium Galliarum needed protecting, not only the hostile Barbarian tribes across the Danube but also his enemy the 'legitimate' Roman emperor Gallienus who tried, unsuccessfully, to remove Postumus from what he surely considered to be his legitimate seat of power.

Admittedly, what I offer above is a fairly idealistic view of the creation and impact of the iconography on imperial Roman coins. It needs to be pointed out

24 Luther, "Das Gallische Sonderreich," pp. 338-40. Eck, "Das Gallische Sonderreich," p. 74. See above, note 21, for an inscription in which Postumus is noted as being the consul, the pontifex maximus, a proconsul, as well as having tribunician power.

25 AE 1993.1231. The inscription is used also by Potter, The Roman Empire at Bay, p. 256 and Eck, "Das Gallische Sonderreich," p. 66 to demonstrate that the Imperium Galliarum was an entity distinct from the rest of the Roman state. 
that there is great scholarly debate over the precise nature of the images which appeared on Roman coins, centered around the issues of what authorities were responsible for choosing the images and text as well as how much ordinary users of the coins actually attended to, or were impacted by, the messages. ${ }^{26}$ This is not the proper place for a lengthy recapitulation of the arguments concerning the impact of coin iconography except to note that most scholars now agree that the images on Roman coins expressed the ideals and aims of the ruling authorities under whose name the coins were being produced, regardless of the level of direct control ruler's asserted in creating the images. ${ }^{27}$ The extent to which coin users paid attention to the images and text on these objects and, thus, the impact which the coins' iconographic messages had is impossible to determine. Let it suffice for the purposes of this article to conclude that the images and text on coins produced by the Postumus as well as the central Roman emperors during the third century were consistent with the persona these rulers wished to present to their subjects.

Accepting the evidence from coin iconography and combining it with the epigraphic material, it is clear that Postumus was not trying to reject entirely Roman political and ideological norms and establish a completely different manner of rule in his new breakaway territory. This is, indeed, the main reason why many scholars have argued that Postumus intended to march on Rome and rule over a united Roman Empire just as all other claimants, but was prevented from it by certain unknown causes, such as internal issues or

26 For useful overviews concerning Roman numismatic iconography, see notably Andrew Burnett, Coinage in the Roman World (London, 1987), pp. 66-85. ibid., Coins (London, 1991), pp. 38-9. Harl, Coinage in the Roman Economy, 300 B.C. to A.D. 7oo, pp. 74-7. Nathan T. Elkins, "Coins, Contexts, and an Iconographic Approach for the 21st Century," in Coins in Context I: new perspectives for the interpretation of coin finds ed. Hans-Markus von Kaenel and Fleur Kemmers (Mainz, 2009), 25-46.

27 William E. Metcalf, "The Emperor's Liberalitas: Propaganda and the Imperial Coinage," Rivista Italiana Di Numismatica E Scienze Affini 95 (1993), 337-46. Carlos F. Noreña, "The Communication of the Emperor's Virtues," Journal of Roman Studies 91 (2001), 146-68. Andrew Meadows and Jonathan Williams, "Moneta and the Monuments: Coinage and Politics in Republican Rome," Journal of Roman Studies 91 (2001), 27-49. Olivier Hekster, "Coins and Messages. Audience Targeting on Coins of Different Denominations?" in Representation and Perception of Roman Imperial Power, ed. Lukas de Blois et al. (Amsterdam, 2003), 20-35. Georges Depeyrot, La propagande monétaire (64-235) et le trésor de Marcianopolis (251) (Wetteren, 2004). Volker Heuchert, "The Chronological Development of Roman Provincial Coin Iconography," in Coinage and Identity in the Roman Provinces, ed. Christopher J. Howgego, Volker Heuchert, and Andrew Burnett (Oxford, 2005), 29-56. Elkins, "Coins, Contexts, and an Iconographic Approach for the 21st Century." 
simply the power of the central Roman army. ${ }^{28}$ Yet, as mentioned, Postumus' rule was unquestionably different from the other usurper-emperors of the period in certain respects. Put simply, it is difficult to uphold a simple reading of Postumus and of his Gallic Empire as an 'outsider' entity, something completely foreign to imperial Rome, nor should it be thought of as an 'insider' territory either. In other words, the subjects of the Imperium Galliarum may have still considered themselves to be Romans and may have seen Postumus as the one legitimate emperor, but the fact remains that the division between the factions supporting the Gallic emperors and those of supporting the central emperors were explicitly enemies for a considerable number of years. Those living in the Gallic Empire's territory, therefore, were still Roman in a certain sense, but they can not, after AD 260, have been 'Roman' in quite the same way that people living, for instance, in Italy or Spain were.

This brief summary of Postumus' rule reveals that the Imperium Galliarum was a complex entity; while Postumus maintained certain Roman ideological and administrative institutions, his authority was based on his control over local resources and manpower within a clearly circumscribed territory. The Imperium Galliarum existed at once 'inside' traditional Roman imperial structures, yet still 'outside' the authority of the central government. In order to test the precise extent to which Postumus' Gallic Empire was unique within the context of the problems of the third century AD and, more importantly, to gain some sense of what caused Postumus' Empire to take the shape that it did, it is necessary to briefly explore another case-study as a counterbalance to the first. This leads, then, to the next episode to be discussed here, namely the events that occurred in North Africa during AD 238, the 'year of the seven emperors.'

AD 238 is notable for being typically understood as the beginning of the third century's troubles, as the year which saw, among other things, the ascension of Gordian I and his sons to the emperorship at Rome. ${ }^{29}$ The problems of the year actually began three years earlier in AD 235 when the last of the Severan rulers, Severus Alexander, was murdered by a non-aristocratic soldier named

28 Eck, "Das Gallische Sonderreich," p. 81.

29 The best source for the events of AD 238 remains Herodian, with the Historia Augusta and Zosimus providing some useful material as well. For a somewhat more complete summary of the period than I provide here, most useful is Potter, The Roman Empire at Bay, pp. 167-72. See also Arbia Hilali, "Le crise de 238 en afrique et ses impacts sur l'Empire romain," in Crises and the Roman Empire: Proceedings of the Seventh Workshop of the International Network Impact of Empire, Nijmegen, June 20-24, 2006, ed. Olivier Hekster, Gerda de Kleijn, and Daniëlle Slootjes (Leiden, 2007), pp. 57-65 specifically on the activity in Africa. 
Gaius Iulius Verus Maximinus, or Maximinus Thrax. Maximinus was the first of the so-called Soldatenkaiser and, as a non-elite usurper who had claimed the throne through violence, he was not accepted by the Roman ruling aristocracy. ${ }^{30}$ In $\mathrm{AD} 238$, some of the leading Roman citizens living in Africa Proconsularis murdered the province's procurator, then roused the elderly senator and former governor Marcus Antonius Gordianus, or Gordian I, out of retirement on his estate in Thysdrus, convincing him to revolt against Maximinus and to take the throne in Rome. Gordian's supporters in Rome, in preparation of his arrival, murdered both the Praetorian and the Urban Prefects, and the senators in Rome declared Gordian emperor and defender of the Empire against the illegitimate usurper Maximinus.

Meanwhile, with Gordian and his son, Gordian II, in Carthage getting ready to march on Italy, the legate of the African province of Numidia, a certain Capellianus, chose to oppose Gordian's rebellion. As legate, Capellianus was in command of the soldiers of the Legio III Augusta, the sole legionary force in all of the Africa territory, ${ }^{31}$ and it was this force that he led into Proconsularis against Gordian and his supporters. Gordian's son was killed in battle against Capellianus at Carthage, at which news the elder Gordian committed suicide. The senate in Rome, upon learning this, hailed the aristocrats Pupienus and Balbinus co-emperors along with Gordian's grandson, thirteen-year-old Gordian III, as their junior Caesar. Maximinus then invaded Italy, but was murdered by his own troops during an unsuccessful siege of Aquileia. Shortly thereafter, Pupienus and Balbinus were also murdered by their own troops, leaving the young Gordian III as sole emperor, the seventh person hailed emperor that year. This left Capellianus alone in Africa without allies, and the young emperor temporarily disbanded the legio III Augusta for their role in the death of his father and grandfather. ${ }^{32}$

Although none of the claimants to the throne during this year were able to hold on to power for any length of time apart from the young Gordian III, all

3o On the senatorial opposition to Maximinus during this period, see particularly Dietz, Senatus contra principem: Untersuchungen zur senatorischen Opposition gegen Kaiser Maximinus Thrax, pp. 333-6.

31 On Africa's military situation, see notably Elizabeth W.B. Fentress, Numidia and the Roman Army: Social, Military and Economic Aspects of the Frontier Zone (Oxford, 1979). Yann Le Bohec, La troisième Légion Auguste (Paris, 1989). Pierre Morizot, "Impact de L'armée Romaine Sur L'économie de l'Afrique', in The Roman Army and the Economy, ed. Paul Erdkamp (Amsterdam, 2002), pp. 345-74.

32 It is worth noting, though, that the legion was reformed under the emperor Valerian in the AD 250 and continued its main role of guarding the African limes against invading nomadic tribes. 
of them, immediately upon being hailed emperor, assumed the trappings of a legitimate, traditional Roman emperor. In inscriptions, for instance, we see Gordian III with the traditional titles Imp (erator) Caes(ar) M(arcus) Antonius Gordianus Pius Felix Invictus Augustus. ${ }^{33}$ Even the first two Gordiani, although their rule was quite short lived, are addressed in surviving inscriptions using the appropriate titulature of an imperial dynasty. ${ }^{34}$ An interesting dedicatory inscription from Aigeai in Cilicia, probably dating to late in AD 238 or 239, refers to all three Gordiani together along with the entire Severan line. Clearly, this inscription is attempting to fit the usurper dynasty of the Gordiani into the legitimate line of succession of the previous ruling family which was, as the inscription seems to imply, interrupted by the illegitimate usurper Maximinus. ${ }^{35}$ Maximinus himself, of course, did not share this view of his reign, and there exist inscriptions hailing him with the traditional titulature as Imperator Caesar Caius Iulius Verus Maximinus Pius Felix Augustus Germanicus maximus Sarmaticus maximus Dacicus maximus, signifying him as a legitimate emperor and highlighting his military exploits. ${ }^{36}$ Further, all of the emperors of $A D 238$ issued coins that survive in fairly large quantities, especially those of Gordian III. These coins looked like the normal imperial Roman coinage, featuring the emperor's bust on the obverse and reverse types that highlighted each emperor's liberality, generosity, and faithful care of military matters and the prosperity of the Roman people. ${ }^{37}$

Much about this episode, thus, looks similar to the events surrounding the formation of the Gallic Empire, which, as mentioned, has led some scholars to treat both events as parts of the same, larger period of turmoil during the mid-third century AD. Indeed, in the African case, as with the latter Gallic one, usurpations of political authority by popular military leaders led to multiple claimants to imperial rule and civil fighting between their factions of supporters. Likewise, all of the rulers during the 'year of seven Emperors' in AD 238 acted in the same fashion as previous emperors, adopting the normal imperial titles, appointing subordinate officers, and minting coins in their own image

33 AE 1987.109ob (= ILAfr.614), a dedicatory inscription of a balineum restored by the emperor from Volubilis in modern-day Morocco.

34 For instance, in a fragmentary inscription from Palaestina [AE 1978.826] Gordian I is hailed as Imperator, Pius, Felix, and Augustus.

35 SEG 32.1312.

36 See, for an example, a dedicatory inscription [AE 2007.1713 (=ILAfr.661)] honoring both Maximinus and his son for rebuilding collapsed bridges in Masclianae in Africa Proconsularis, heartland of the Gordiani and their supporters.

See Roman Imperial Coinage vol. 4, part 2 for the coin types of this period. 
with messages highlighting their imperial authority and benefaction to the Roman people. All of which, again, was also done by Postumus and his fellow Gallic emperors.

Unlike with Postumus' Empire, however, the civil fighting in Africa in AD 238 did not circumscribe central Roman authority in any meaningful way, nor did it lead to the establishment of a large stretch of territory governed separately from Rome for any sustained period. In short, Africa at no point stood 'outside' of the Empire to the extent that the Imperium Galliarum did, in terms of being an enemy of the central Roman Empire. The crucial question, then, is why not? Or, to put it another way, what were the central factors driving the divergent reactions that these two regions had to similar ideological and political circumstances? To answer this, a comparison between the regions must be made, focusing on the military, economic, and financial factors that impacted the period, in order to highlight the broader historical context in which these events occurred and out of which these periods of turmoil arose.

\section{$4 \quad$ Military Differences}

The first point of comparison I will address is the military environment in the two regions. As mentioned, the central basis of Postumus' authority was his control over the considerable military resources of northern Europe, particularly the vast numbers of soldiers, bases, and forts along the Danubian frontier. Indeed, this part of the Empire had seen a steady influx of soldiers beginning already in the Antonine period from the Marcomannic Wars under Marcus Aurelius in the AD 160 s. $^{38}$ Clearly, the large number of soldiers that fell under Postumus' command after the siege of Cologne in AD 260 allowed him to exercise and consolidate his authority over the territory occupied by these soldiers as well as to thwart Gallienus' attempts at reunification. Nevertheless, the military might of the Imperium Galliarum cannot be analyzed in isolation, as though it sprang up simultaneously with Postumus' rise to power. Rather, this military power was already an integral part of the northwestern part of the Empire from the late second century AD and became increasingly more

38 On these wars see especially András Mócsy, Pannonia and Upper Moesia: A History of the Middle Danube Provinces of the Roman Empire (Boston, 1974). Péter Kovács, Marcus Aurelius' Rain Miracle and the Marcomannic Wars (Leiden, 2009). For the military aspect of the third century crises generally, see notably de Blois, "The Military Factor in the Onset of Crises in the Roman Empire in the Third Century AD." 
powerful and important as emperors continued to send vast armies to the Germanic provinces over the course of the third century.

Given the importance of the army and the extent to which all emperors relied on the military to legitimate their rule, then, this great concentration of Rome's military power in northwestern Europe beginning in the late Antonine period certainly would have had a splintering effect on the region already in the late second century. This is not to say that Postumus' usurpation was inevitable, or even that a similar fracturing of the imperial state into a territory like the Imperium Galliarum could just as easily have occurred earlier, although this is certainly a possibility. I am arguing, however, that the high degree of military activity and the large number of soldiers settled in the Gallic and Germanic provinces from the late second century began the process of dislocating imperial authority in that region. The process of northeastern Gaul and western Germany falling 'outside' the central state's sphere of control, in terms of military and political authority, was thus a long process of which Postumus was the culmination. Moreover, this was a fairly unique situation within the Empire, particularly in the western half. ${ }^{39}$ It seems highly likely, therefore, that this peculiar military situation was a precondition for the peculiar way that events in the region played out during the $\mathrm{AD} 260 \mathrm{os}$.

The military situation in northern Europe, again, stands in stark contrast to that in the rest of the western Empire, particularly Africa. As noted above, the African provinces were relatively under-militarized throughout the imperial period, hosting only one legionary force for the entire region. The chief military duty of this legion seems to have been protecting and enforcing the borders of Roman control from the threat of invasion by largely nomadic Numidian tribes

39 As mentioned, frequently a comparison is made between Postumus' territory and the Palmyrene Empire of Odaenathus and, after his death, his wife Zenobia and their son Vaballathus. The similarity between these cases extends beyond the mere fact that they are both often considered breakaway kingdoms; Palmyra was as much an exception in the East as northern Gaul and Germany were in the West. For, like the Danubian provinces, Palmyra was on the outskirts of Roman territory and had seen a large influx of soldiers over the course of the third century due to Roman battles against the Parthian and Sasannid Persians to the East. The main difference is that Odaenathus was granted authority by Gallienus, whom Odaenathus likewise recognized as the legitimate emperor, and it was only after his death in AD 270 that his wife Zenobia revolted from the central authority and the Palmyrene territory became a truly independent entity. On this, see notably Potter, The Roman Empire at Bay, pp. 257-68. Peter M. Edwell, Between Rome and Persia: The Middle Euphrates, Mesopotamia and Palmyra under Roman Control (New York, 2008), pp. 63-92. Andrew M. Smith, Roman Palmyra: Identity, Community, and State Formation (Oxford, 2013), pp. 175-81. 
to the South. ${ }^{40}$ Even in the late second and throughout the third century AD, however, as the Danubian frontier as well as the border between Rome and Persia in Mesopotamia in the eastern half of the Empire saw prolonged periods of hostility and the concomitant influx of military power, Africa remained remarkably peaceful. ${ }^{41} \mathrm{In} \mathrm{AD} 238$, then, when the region did experience a rare moment of instability and civil fighting, there were no preexisting 'fault lines' pushing the region towards disintegration as there were a few decades later in Gaul as well as in Palmyra to the East due to the large presence of an independent basis of power, namely armies, to be exploited by local leaders.

\section{Economic Differences}

The military factor, thus, looms large as a potential causal force for the different experiences of the two cases under consideration here. A corollary to the military situation that also deserves some attention is the general economic well-being of the two regions at the time that turmoil arose. In Gaul, Germany, and also in Britain, the weakening of imperial authority that occurred over the course of the late second and throughout the third centuries AD, hastened by the heavy concentration of soldiers in the region, was also attended by a weakening of economic productivity. It is difficult to say whether the military factor was the primary cause of the troubles and the economic secondary, or vice versa. Likely, the two issues were reinforcing.

It is clear, however, that Gallic production of export goods tapered off significantly during the mid to late second century AD. This is seen most clearly from the ceramic evidence. Gaul and, to a lesser extent, Britain, had been active centers for producing ceramics, both fine-ware and transport amphorae, for local as well as inter-regional distribution in the first and early second century AD. This production, though, fell off considerably in the later part of the second century and was nearly absent for most of the third, except for limited

$40 \quad$ Le Bohec, La troisième Légion Auguste, p. 573.

41 On the general stability of North Africa throughout the third century: Robert Turcan, "Le trésor de Guelma: étude historique et monétaire” (Paris, 1963), pp. 25-35. Marcel Bénabou, La résistance africaine à la romanisation (Paris, 1976), pp. 214-40. Fentress, Numidia and the Roman Army, p. 117. Claude Lepèlley, "l'Afrique," in Rome et l'intégration de l'Empire: 44 av. J.-C.-26o ap. J.C., tome 2: Approche régionales du Haut-Empire, ed. Claude Lepèlley (Paris, 1998), 71-112, pp. 105-9. Claude Lepelley, "The Survival and Fall of the Classical City in Late Roman Africa," in The City in Late Antiquity, ed. John Rich (New York, 1992), 50-76, p. 55. David Cherry, Frontier and Society in Roman North Africa (Oxford, 1998), pp. 58-66. 
production restricted to regional distribution. ${ }^{42}$ While it is, admittedly, difficult to tie ceramic manufacturing directly to other aspects of the economy, it is undeniable that there is a strong relationship between the ability to produce a surplus of goods that are transported in ceramics to other regions, on the one hand, and general economic well-being, on the other. It is undeniable also, then, that the Gallic and Germanic provinces, along with Britain, suffered from a significant decline in productivity and in export trade at the same time as the disruptive presence of large numbers of soldiers were flooding into these regions. Notably, the only areas of northwestern Europe which maintained any significant ceramic production during the period were southern Gaul, namely the province of Narbonensis, and Baetica in Spain, the two areas in which the Gallic emperors had the most trouble maintaining power. ${ }^{43}$ The economic situation thus combined with the military in creating fault lines pushing the area further and further 'outside' of the control of the central Roman authority for several decades before Postumus came on the scene.

Again, the experience of Africa in this regard is quite opposite from that of northern Europe. Ceramics made in Africa feature fairly prominently in assemblages throughout the Mediterranean beginning in the late second century AD and lasting until Late Antiquity. ${ }^{44}$ This includes particularly fine-wares,

Michael Fulford, “Territorial Expansion and the Roman Empire," World Archaeology 23/3 (1992), 294-305. Christopher J. Going, “Economic 'Long Waves' in the Roman Period? A Reconnaissance of the Romano-British Ceramic Evidence," Oxford Journal of Archaeology 11/1 (1992), 93-117. Paul Reynolds, "Trade Networks of the East, 3rd to 7th Centuries: The View from Beirut (Lebanon) and Butrint (Albania)(fine Wares, Amphorae and Kitchen Wares)," in $\mathrm{LRCW}_{3}$. Late Roman Coarse Wares, Cooking Wares and Amphorae in the Mediterranean: Archaeology and Archaeometry. Comparison between Western and Eastern Mediterranean, ed. Simoneta Menchelli et al. (Oxford, 2010), 89-114. Tamara Lewit, "Dynamics of Fineware Production and Trade: The Puzzle of Supra-Regional Exporters," Journal of Roman Archaeology 24 (2011), 313-32.

Pedro Paulo Abreu Funari, "Baetica and the Dressel 20 Production An Outline of the Province's History," Dialogues D’histoire Ancienne 20/1 (1994), 87-105, pp. 94-5.

44 David P.S. Peacock, Fathi Bejaoui, and Nejib Ben Lazreg, "Roman Amphora Production in the Sahel Region of Tunisia," in Amphores romaines et histoire économique: dix ans de recherché (Rome, 1989). ibid., "Roman Pottery Production in Central Tunisia," Journal of Roman Archaeology 3 (1990), 59-84. Simon Keay, "African Amphorae," in Cerámica in Italia: VI-VII Secolo. Atti Del Convegno in Onore Di John W. Hayes, ed. Lucia Saguí (Rome, 1998), 141-55. Elizabeth Fentress et al., "Accounting for ARS: Fineware and Sites in Sicily and Africa," in Side-by-Side Survey: Comparative Regional Studies in the Mediterranean World, ed. Susan Alcock and John F. Cherry (Oxford, 2004), 147-62. Michel Bonifay, "La céramique africaine, un indice du développement économique?," Antiquité Tardive 11/1 (2004), 113-28; ibid., "Observations sur la diffusion des céramiques africaines en 
which make up a significant portion of the ceramic material from the Eastern Mediterranean, as well as, to a lesser extent, the amphorae made in the region to transport the products of African agricultural production, notably olive oil, wine, and garum. ${ }^{45}$ Not only did the African economy survive the turmoil of the third century AD that ravaged so many parts of the Empire, but by all indications African production actually grew during this time. Indeed, new centers of ceramic production established in the third and early fourth centuries have been identified particularly in the interior parts of Africa Proconsularis. The region similarly saw a great amount of urban growth along with the development of non-agricultural economic activities such as textile manufacture and fish-salting. ${ }^{46}$ Crucially, moreover, much of this African production was geared

Méditerranée orientale durant l'antiquité tardive," in Mélanges Jean- Pierre Sodini, ed. François Baratte (Paris, 2005), 565-81. J. Theodore Peña, "The Quantitative Analysis of Roman Pottery: General Problems, the Methods Employed at the Palatine East, and the Supply of African Sigillata to Rome," in Supplying Rome and the Empire, Proceedings the International Seminar "Rome, Provinces, Production and Distribution" Held at Siena-Certosa Di Pontignano (May 2-4, 2004), ed. Emanuele Papi (Providence, 2007), 153-72. John W. Hayes, The Athenian Agora: Results of Excavations Conducted by the American School of Classical Studies at Athens. vol. 32, (Princeton, 2008). Philip Bes and Jeroen Poblome, "African Red Slip Ware on the Move: The Effect of Bonifay's Etudes for the Roman East," in Studies in Roman Pottery of the Provinces of Africa Proconsularis and Byzacena (Tunisia), ed. John H. Humphrey (Providence, 2009), 73-91.

45 Andrew Wilson, "Marine Resource Exploitation in the Cities of Coastal Tripolitania," in L'Africa Romana XIV, vol. 1, ed. Mustapha Khanoussi, Paola Ruggeri, and Cinzia Vismara (Rome, 2002), 429-36. Jean-Pierre Brun, Archéologie du vin et de l'huile dans l'Empire romain (Paris, 2004). David Mattingly, "A New Study of Olive Oil (and Wine?) Production in Northern Tunisia," Journal of Roman Archaeology 22 (2009), 715-20. Annalisa Marzano and Giulio Brizzi, "Costly Display or Economic Investment? A Quantitative Approach to the Study of Marine Aquaculture," Journal of Roman Archaeology 22 (2009), 215-30.

46 Clementina Panella, "Le anfore di età imperiale del Mediterraneo occidentale," in Ceramique Hellenistique et Romaines, ed. Jean-Paul Morel, Pierre Lévêque, and Évelyne Geny, vol. 3 (Paris, 2001), 177-275. Andrew Wilson, "Urban Production in the Roman World: The View from North Africa," Papers of the British School at Rome 70 (2002), 231-73. Elizabeth Fentress et al., "Accounting for ARS: Fineware and Sites in Sicily and Africa," in Side-by-Side Survey: Comparative Regional Studies in the Mediterranean World, ed. Susan Alcock and John F. Cherry (Oxford, 2004), 147-62. Michael Mackensen, "The Study of 3 Rd Century African Red Slip Ware Based on the Evidence from Tunisia," in Old Pottery in a New Century. Innovating Perspectives on Roman Pottery Studies, ed. Danielle Malfitana, Jeroen Poblome, and John Lund (Catalina, 2004), 105-24. Michel Bonifay, "Observations sur la diffusion des céramiques africaines en Méditerranée Orientale durant l'antiquité tardive," in Mélanges Jean- Pierre Sodini, ed. François Baratte (Paris, 2005), 565-81. Bes and Poblome, "African Red Slip Ware on the Move: The Effect of Bonifay's Etudes for 
for export, judging at least by the ceramic evidence, meaning that a significant part of Africa's economic prosperity at the time was tied inextricably to their connection to the rest of the Roman world.

When a group of wealthy Roman aristocrats convinced Gordian I to come out of retirement in order to lead a rebellion against the emperor Maximinus, then, they did so in an environment with a thriving economy dependent on maintaining links to and interaction with the other areas under the control of the central Roman state. These aristocrats, the same elite Romans who held much of the land on which Africa's crops were produced and who were the main force behind the development of the region's ceramic and urban industries, thus had little incentive to support or encourage any act of separation from the rest of the Empire. ${ }^{47}$ I do not mean to imply that Gordian or his supporters were necessarily basing their plans explicitly on these economic considerations, but it would be equally foolish to deny that the fact that many of Africa's elite owed much of their wealth and, thereby, their position to the region's surplus production and economic links with the rest of the Mediterranean factored into the decisions made during this tense time. ${ }^{48}$

It is notable too, and undeniable, that as a result of the decisions made by Gordian and his supporters, whatever their individual motivations or concerns actually were, the African economy continued to operate uninterrupted and even to expand for the next century or so. Even the invasion of Proconsularis with the legio III Augusta by Capellienus, although it resulted in outright civil violence and the disarmament of the legion, did nothing to alter the region's economic life, nor, equally important, its political and social stability; in other words, its 'insideness'. It seems that only a major, catastrophic event would have been able to disrupt Africa's cohesion and ties to the central Roman state during the third century AD, a very different context than the one in Gaul and

the Roman East," in Studies in Roman Pottery of the Provinces of Africa Proconsularis and Byzacena (Tunisia).

47 See Daniel Hoyer, "Public Feasting, Elite Competition, and the Market Economy of Roman North Africa," The Journal of North African Studies 18/4 (2013), 574-91 for a discussion of the role of local, urban elite in Africa's economic development in the imperial period.

48 Dietz, Senatus contra principem, pp. 333-4 notes, with some surprise, that most of the senators and other ruling elite who chose to rebel against Maximinus in AD 238 came from families who had received favor from, and thus remained loyal to, the Severan rulers, including the Gordiani. I am not discounting the socio-political importance of loyalty to a ruling dynasty. Rather, I am arguing here that part of the benefits that these elite Roman families received from the Severans, especially those living in Africa, and therefore part of the reason they would remain loyal to Severan supporters, was the income they gained from the region's flourishing economy. 
Germany where the region seems to have been ripe for a major dislocation of imperial authority.

\section{$6 \quad$ Financial Differences}

The differences in military activity and economic prosperity noted above had another major effect that deserves attention here, namely in terms of the broad financial stability of the different regions. The financial changes of the period are seen best by studying the coinage that circulated in the different regions at the time. The ideological force of the coinage produced by the Gallic emperors as well as the several claimants to the throne of AD 238 has been discussed already. Certainly these coins served to reinforce and spread an image of the emperor issuing them as the supreme power for the whole, unified Roman world and the people under his authority. The financial impact of Roman coins, however, must not be overlooked. The significance of developments in the Roman currency system for the purposes of this article is that the changes made to the coinage and their broader impact on other aspects of Roman life were also experienced with regional differences.

As mentioned, Postumus issued a vast number of coins during his reign, mainly billon antoniniani ${ }^{49}$ but also small amounts of true bronze coins, particularly a double sestertius. Like much of the other economic material produced in the Imperium Galliarum during this period, the coins of the Gallic Empire

49 Billon refers to a coin made prominently with bronze, but plated with silver. The billon antoniniani produced during this time were fairly high-value coins, tariffed at two denarii, but contained far less valuable metal than the imperial denarii. On this, see notably Jean-Pierre Callu, La politique monétaire des empereurs romains, de 238 à 311 (Paris, 1969). p. 197. Elio Lo Cascio, "Dall'antoninianus al “laureato grande"': l'evoluzione monetaria del III secolo alla luce della nuova documentazione di etadioclezianea," Opus 3 (1984), 133201. Jean-Luc Desnier, "Le trésor du Puy-Dieu," Trésors Monétaires 7 (1985), 33-104, p. 33. Hollard, "la circulation monétaire en Gaul au III" siècle après J.-C.," p. 209. Harl, Coinage in the Roman Economy, 30o B.C. to A.D. 70o, pp. 128-9. Carrié, "Les crises monétaires de l'Émpire romain tardif (274-36o ap. J.-C)," pp. 137-8. Roger Bland, "From Gordian III to the Gallic Empire (AD 238-274)," in The Oxford Handbook of Greek and Roman Coinage, ed. William E. Metcalf (Oxford, 2012), 514-37, pp. 516-25. Daniel Hoyer, "Crisis and Calm: Regional Differences in the Western Roman Empire during the ard Century CE as seen from the Coin Evidence," in Proceedings from the workshop What is "Economic Crisis" in Antiquity? ed. Véronique Chankowski, (forthcoming). 
had almost an exclusively regional circulation within the Gallic territory ${ }^{50}$ Postumus issued so many coins, it seems, primarily to pay the troops upon whom he relied heavily as his basis of power and authority. ${ }^{51}$ Indeed, one of the major advantages Postumus held in the territory of the Imperium Galliarum was his control of the mints at Cologne and at Trier. This allowed him to produce the large quantity of coinage he needed to continually furnish his supporters with largess. In Africa, conversely, there had been no local minting of coinage since the production of some bronze coins under emperor Tiberius in the mid first century AD. ${ }^{52}$ Neither Gordian I, nor Capellienus, nor any other ambitious Roman in Africa therefore had the opportunity to appropriate any minting facilities from the central state and redirect coin production for their own purposes, as Postumus was able to do. All of the coinage produced by the emperors of AD 238 was minted in Europe, mainly at Rome..$^{53}$

Furthermore, not only did Postumus and the other Gallic emperors produce vast quantities of coinage, but their coins were of rather low value. The billon antoninianus, the primary type produced by the Gallic emperors, was first introduced under Caracalla as a cost-saving effort for the Roman treasury in around $\mathrm{AD} 215 \cdot{ }^{54}$ At this time, the Roman authorities were suffering from a shortage in precious metal, as many of the main sources of silver had begun

5o Jean-Pierre Callu, "approches numismatiques de l'histoire du $3^{\mathrm{e}}$ siècle: $23^{8-311, " ~ i n ~ A u f s t e i g ~}$ Und Niedergang Der Römischen Welt, ed. Hildegard Temprini and Wolfgang Haase, vol. 2 (New York, 1975), 594-613, pp. 595-9. Hollard, "la circulation monétaire en Gaul au III siècle après J.-C.," p. 213. Sylviane Estiot, "Le troisieme siecle et la monnaie: crises et mutations," in Le III Siècle En Gaule Narbonnaise: Données Régionale Sur La Crise de l'Émpire, ed. Jean-Luc Fiches (Antipolis, 1996), 33-70, p. 48. Carrié, "Les crises monétaires de l'Émpire romain tardif (274-36o Ap. J.-C)," pp. 138-43.

$5^{1}$ Hollard, "la circulation monétaire en Gaul au III ${ }^{\mathrm{e}}$ siècle après J.-C.," p. 213. Harl, Coinage in the Roman Economy, 30o B.C. to A.D. 70o, p. 145. Estiot, "le troisieme siecle et la monnaie: crises et mutations," p. 36 .

52 See Andrew M. Burnett et al., Roman Provincial Coinage, vol. 1 (London, 1992) for an overview of the numismatic evidence from the African provinces.

53 Unfortunately, there exists currently no systematic overview of the numismatic material from Roman Africa during the third century. The most helpful resource for the coinage of these emperors remains the Roman Imperial Coinage volumes, especially the fourth volume. Several eastern mints were also active during this period; on these, see notably Ann Johnston, Greek Imperial Denominations, ca 200-275: A Study of the Roman Provincial Bronze Coinages of Asia Minor (London, 2007).

54 Callu, La Politique monétaire des empereurs romains, de 238 à 311, p. 197 Desnier, "Le trésor du puy-dieu.," p. 33. Hollard, "la circulation monétaire en Gaul au III ${ }^{\mathrm{e}}$ siècle après J.-C.," p. 209. Harl, Coinage in the Roman Economy, зоo B.C. to A.D. 7oo; Roger Bland, "From Gordian III to the Gallic Empire (AD 238-274)", pp. 526-25. 
to dry up in the late second century. ${ }^{55}$ The antoninianus was mainly a bronze coin, made from much cheaper and more abundant metals, and contained only small amounts of silver. The financial importance of the coin is that antoniniani were tariffed at twice the value of the pure-silver denarius that had been the backbone of the Roman currency system since the reforms of Augustus, yet they contained only one and a half times the silver as old denarii. Antoniniani, thus, allowed the state to increase the amount of money in circulation dramatically while conserving precious silver reserves as much as possible.

The reasons for the introduction of this overvalued coin under Caracalla seem to be the result not only of the dwindling supply of silver, but also of increasing costs to the Roman state, particularly in the form of payment and largess distributed to soldiers. It has been noted above that the late Antonine period saw a steady increase in military activity in certain regions of the Empire. This increased activity led to an increase both in the number of soldiers supported by Rome, but also spurred both Septimius Severus and Caracalla to increase military pay and to bestow great financial benefits in order to recruit and retain loyal soldiers, mainly in the form of praemia and donativa. ${ }^{56}$ The minting of antoniniani was abandoned shortly after they were introduced, as they were largely rejected by coin users for being too overvalued. In the AD 230s, however, the same pressures that led Caracalla to introduce the billon coinage were further exacerbated by continually dwindling silver supplies as well as by persistent military conflicts in the North and in the East. Moreover, the beginning of the 'Soldatenkaiser' period in which military leaders were constantly competing with each other for power by bestowing financial benefits on their

55 Keay, "African Amphorae," pp. 172-201. Claude Domergue, Les mines de la péninsule ibérique dans l'Antiquité romaine (Roma, 1990), pp. 215-24.

$5^{6}$ Septimius Severus famously courted military supporters by raising pay for legionary soldiers from the 300 denarii/year it had been under the Antonines to 400 denarii/year. Caracalla raised it a further 200 denarii/year. On this, see particularly Harl, Coinage in the Roman Economy, 300 B.C. to A.D. 70o, p. 216. For the effect of Severan military policy specifically on coinage, see Depeyrot, "Crise économique, formation des prix, et politique monétaire au troisième siècle après J.-C.," p. 236. Richard Abdy, The Severans, ed. William E. Metcalf (Oxford, 2012), 499-513. On the largess distributed to loyal troops by third century emperors, see Richard Duncan-Jones, Money and Government in the Roman Empire (Cambridge, 1994), pp. 33-41. Jean-Michel Carrié, "Les échanges commerciaux et l'État antique tardif," in Économie Antique. Les échanges dans l'Antiquité: Le role de l'État, ed. Jean Andreau, Pierre Briant, and Raymond Descat (Saint-Bertrand-de-Comminges, 1994), 175-211, pp. 193-4. Estiot, "Le troisieme siècle et la monnaie," p. 39; de Blois, "The Military Factor in the Onset of Crises in the Roman Empire in the Third Century AD," pp. $49^{8}-502$. 
supporters, mainly the troops under their command, likewise put pressure on already taxed monetary resources. The antoninianus was, therefore, reintroduced and, from the AD 23os until Aurelian's currency reforms in the mid270 , antoniniani were produced in very large numbers with ever decreasing amounts of silver. ${ }^{57}$

Again, the introduction of the antoninianus was sparked by financial problems which began in the late second century AD, but the creation of a billon currency was not the first manipulation of the currency the Roman state undertook in an attempt to combat these problems. Even before AD 215 when the antoninianus was first minted, the two principal denominations circulating within the Empire, the silver denarius and the bronze-orichalcum sestertius, underwent a series of debasements. ${ }^{58}$ The impact of these debasements, however, was unevenly felt. For the bronze coins, I have demonstrated elsewhere that sestertii minted at Rome and found in Gaul and in Britain were being minted at increasingly lower weights beginning already in AD 161.59 Conversely, the same type of coins which ended up in Africa and Spain did not begin losing weight until later, and even then the debasement of coins found in these regions occurred at a much lower rate than those from the northern provinces. This is not the place to engage in a lengthy discussion of the mechanisms behind this regionalism in currency debasement, but let it suffice to note here simply that it is a clear indication that the financial and economic problems driving debasement as well as the eventual introduction of a billon currency were more severe in northern Europe than in the southern

57 Dominique Hollard, "La crise de la monnaie dans l'Émpire romain: au ze siècle après J.-C. Synthèse des recherches et résultats nouveaux," Annales (1995), 1045-78. Estiot, "Le troisieme siècle et la monnaie," pp. 36-42.

58 Earle R. Caley, Orichalcum and Related Ancient Alloys: Origin, Composition, and Manufacture, with Special Reference to the Coinage of the Roman Empire. (New York, 1964), p. 9o. Callu, La politique monétaire des empereurs romains, de 238 à 311, pp. 115-9. Robert Étienne and Marguerite Rachet, Le trésor de Garonne: essai sur la circulation monétaire en Aquitaine à la fin du règne d'Antonin le Pieux, 159-161 (Bordeaux, 1984), pp. 345-50. Christopher J. Howgego, Ancient History from Coins (London, 1995), pp. 115-21. Harl, Coinage in the Roman Economy, 300 B.C. to A.D. 70o, pp. 125-36. Christopher J. Howgego, "The Circulation of Silver Coins, Models of the Roman Economy, and Crisis in the Third Century A.D. Some Numismatic Evidence," in Coin Finds and Coin Use in the Roman World, ed. Cathy E. King and David G. Wigg (Berlin, 1996), 219-36, p. 222. Johnston, Greek Imperial Denominations, ca 200-275, pp. 7-10.

59 Daniel Hoyer, "Calculating the Use-Wear Rates of Roman Coins Using Regression Analysis: A Case Study of Bronze Sestertii from Imperial Gaul," American Journal of Numismatics 25 (2013), 259-82. 
Mediterranean. Further support for this notion of regionalism in financial crises and currency manipulations comes from the antoniniani themselves; the vast majority of antoniniani produced in the mid-third century AD that survive today were found in Gaul, Germany, and Britain, the very areas controlled by Postumus. ${ }^{60}$ Similarly, not only are antoniniani finds relatively scarce in Africa, but these coins do not begin showing up in African hoards until the late $250 \mathrm{~s} .{ }^{61}$

This all caused what can only be described as a fracturing of the western Empire into distinct monetary zones which matched the different military and economic areas discussed previously: the relatively early and severe debasement of the traditional denominations along with the early introduction of the antoninianus in the northwestern zone; and the continued use of the traditional denominations at relatively stable weights and values in southern Europe and Africa. The 'solutions' attempted by the Roman state to solve the issues facing them in northern Europe, moreover, only exacerbated the problems. Debasement and the introduction of the overvalued billon antoninianus were intended to allow the state to expand the number of coins in circulation drastically without a similarly sharp rise in the amount of precious metal being used. This increase in coinage, which, again, was aimed primarily at the regions with the largest concentrations of soldiers in northern Europe and in the East, led also to an inflationary period in these same areas, certainly monetary inflation if not also price inflation. ${ }^{62}$ It has been noted too that Gaul saw a vast increase in imitation of both antoniniani and sestertii during this period, particularly under the Gallic emperors, another sign that the currency manipulations of the time were not able to adequately supply people's requirements for usable, good quality coins, leading to serious and widespread tensions in the financial system of northern Europe generally. ${ }^{63}$

6o Hollard, "la circulation monétaire en Gaul au IIIe siècle après J.-C.," p. 213. Estiot, "Le troisieme siècle et la monnaie," pp. 41-52. Carrié, "Les crises monétaires de l'Émpire romain tardif (274-36o Ap. J.-C.)," p. 138. Gricourt and Hollard, "Les productions monétaires de Postume en 268-269 et celles de Lélien (269). Nouvelles propositions", p. 144.

61 Callu, "Approches numismatiques de l'histoire du ze siècle," p. 599. Estiot, "Le troisieme siècle et la monnaie", p. 48.

62 Depeyrot, "Crise économique, formation des prix, et politique monétaire au troisième siècle après J.-C.," p. 235. Estiot, "Le troisieme siècle et la monnaie," 42-52. Hollard, "La crise de la monnaie dans l'Émpire romain", pp. 1057-69. Carrié, "Les échanges commerciaux et l'État antique tardif.," p. 194. ibid., "Les crises monétaires de l'Émpire romain tar$\operatorname{dif}(274-360$ Ap. J.-C)", p. 143 .

63 Michael H. Crawford, "Finance, Coinage and Money from the Severans to Constantine," in Aufsteig Und Niedergang Der Römischen Welt, ed. Hildegard Temprini and Wolfgang 
Indeed, it is possible that this inflationary spike was instrumental also in the decline of economic production in the affected areas noted above. For, the debasements and increase in number of coins circulating would have caused the intrinsic value of the coins to constantly change, as would the influx of a great quantity of low-quality imitation coins, making investing and loaning money a highly risky proposition. With a decline in investment and loaning, moreover, there would follow a decline in the production supported by such investment. There does, in fact, seem to have been a general trend away from investment and the establishment of endowment funds over the course of the third century AD leading into the early fourth century, when the successive deflationary reforms of Aurelian and Diocletian reestablished some semblance of financial order. ${ }^{64}$ Again, the contrast with Africa is striking. That region was able not only to maintain a high degree of economic activity, but even further to develop its productive capacity during this time, phenomena which required large amounts of investment and, thus, a stable economic and financial environment. This economic prosperity was, therefore, inextricably linked with the relatively stable and high quality currency that continued to circulate in the region, itself tied up with the relative lack of a large, disruptive military force in the area.

\section{Conclusion}

The preceding pages illuminate that the problems, or 'crises', which afflicted Gaul in the AD 260 s and Africa in AD 238 did not sprout up suddenly in the middle of the century, but rather were largely the product of a series of disruptive factors whose origins stretched back to the late Antonine period. It is, as far as I can ascertain, fairly novel to suggest that long-term differences in the aspects of Roman life that I identify as the key factors affecting the periodnamely military activity, economic productivity, and financial stability—had a significant impact on the manner in which the events of the third century unfolded. Yet, as I have illustrated in this article through a direct comparison of these two regional case studies, many of the vital political and strategic decisions made by the various actors involved in the episodes discussed here were based in part on the military, economic, and financial settings in which they

Haase (New York, 1975), 560-93, p. 510. Estiot, "Le troisieme siècle et la monnaie," p. 41 Hollard, "la circulation monétaire en Gaul au IIIe siècle après J.-C.," p. 212.

64 Carrié, "Les échanges commerciaux et l'État antique tardif". ibid., "Solidus et credit: qu'est-ce que l'or a pu changer?". 
acted. In other words, these factors and the contexts they created set the stage for the particular type of political upheaval, usurpations of central authority, and civil warfare that occurred in northwestern Europe as well as in North Africa during the mid-third century AD, respectively.

In the Gallic and Germanic provinces, Postumus came to power in an environment that had experienced nearly one hundred years of military turmoil and the financial problems associated with a heavy concentration of troops who were receiving increasingly generous imperial compensation for their support. Postumus seized upon the opportunity offered by the anger of his troops at the imperial authorities in $\mathrm{AD} 260$ by leading them in the murder of the Praetorian Prefect and the capture and pillaging of Cologne. He then continued to furnish his loyal troops with financial rewards for their support for the rest of his rule, a policy followed by nearly all emperors at least since Septimius Severus and one that persisted into the fourth century AD. In part, the troops' anger about their treatment by the Prefect and the isolation of the central state authorities in the region were products of a protracted period of disruption and dislocation in the normal functioning of the regions' military, economic, and financial institutions, although the Gallic emperors took great pains to maintain certain ideological and political continuities with their imperial Roman past. Moreover, Postumus' need for continual supplies of coinage to reward his soldiers' loyalty only exacerbated these preexisting problems, leading to a further strengthening of the position of soldiers as well as to further debasements, inflation, and economic decline. Only with the reunification of central Roman authority by Aurelian in AD 274, coupled with his drastic reforms of the Roman currency system, primarily a deflationary measure, did the region begin to recover from the problems that had begun in the $\mathrm{AD} 160 \mathrm{os}$.

This is why North Africa in AD 238 makes such an interesting case study; that year likewise saw coups by popular military leaders, multiple claimants to power who each reiterated the traditional symbols and activities of legitimate emperors, as well as military turmoil remarkably similar to the events which led to Postumus' rule. Yet, Africa saw nothing close to the fracturing of the Roman state that occurred in the AD 260 s. Since the late second century $\mathrm{AD}$, while most of the Roman world was beginning to experience the military, political, and economic problems that would plague most of the Empire until the early fourth century, Africa remained remarkably stable. The region was largely peaceful and certainly under-militarized compared to northern Europe, it maintained and advanced a high degree of economic productivity and prosperity, and even the financial situation remained much healthier there than in the North. The political disruptions and civil fighting which did occur in the 
area during $\mathrm{AD} 238$, then, confronted a vibrant and united region able to withstand a fairly large amount of turmoil without busting at the seams.

Admittedly, there are a few potential problems with the arguments I put forward in this article. Firstly, a somewhat obvious and much more simple answer to the question of why the two case studies are different than what I suggest here could be offered. It might be argued simply that, in the African case, Gordian was considered the legitimate emperor by the senate in Rome, while Postumus was labeled a true usurper opposed by the senate and the central emperor Gallienus. Yet, this simple answer does not hold up to close scrutiny, for in the case of AD 238 Maximinus was, like Postumus, a military leader from northern Europe who led his troops in revolt of the central authorities and claimed power for himself. Maximinus, however, did not consolidate the territory under his control as Postumus later did, but immediately began ruling as though he held authority over a unified Empire. Nor, as far as we can tell from the available evidence, did Capellianus call himself emperor or try to consolidate his hold over Africa, even though he had control of the only army in the region and led a violent revolt against the legitimate central rulers, the Gordiani. Thus, the crucial point is that in both instances we see usurpers from northern Europe opposed by the senate in Rome, yet these usurpers act very differently. Additionally, in the case of Capellianus, we see someone who is put in the same position as other usurpers, yet who chose not to claim imperial authority. The factors I have identified here, then, remain essential to address the reason that these different actors behaved so differently at similar events.

Another simple answer to the difference between the case studies would be that the timing of the two episodes accounts for the difference. Namely, that in $\mathrm{AD} 238$ the Roman world was still too wedded to the concept of a single, unified Empire to allow for the sort of fractioning that occurred in the AD 260 s with not only Postumus, but with Odaenathus' Palmyrene Empire as well. This is, however, to skirt the issue rather than address it, for such an interpretation nevertheless begs the question of exactly what changed between AD 238 and 260 that allowed for a similar impetus, namely the violent revolt against the central Roman authorities by a popular military leader, to result in a fragmentation of the Empire in the one case but not in the other. Thus, the answer is much more complicated than it might at first appear and, as I demonstrate in this article, seems to have more to do with the divergent circumstances and structural realities surrounding Africa in AD 238 and those in northwestern Europe in the late $250 \mathrm{~s}$ and 26 os than with any individual's whims or broad chronological developments.

Finally, it needs to be stressed again that I am in no way trying to diminish the role of Postumus' personal ambition or individual action in creating the 
Imperium Galliarum. Nor am I suggesting that his Empire was a completely foreign state, distinct from and unrecognizable to a Roman population. I note above how, in many ways, Postumus styled himself as a traditional, legitimate Roman emperor ruling over a Roman territory and a Roman people. He was, moreover, largely successful in this goal, and for most of the people living in the Gallic Empire's territory, life went on largely as it had before Postumus' usurpation. It is necessary to keep in mind, however, that life in the region had been going on in an increasingly fragmented manner, isolated from the rest of the Roman world, since the Antonine period. The main point I wish to get across, then, is that, in spite of certain continuities with traditional Roman practice and regardless of whether or not Postumus intended to eventually march on Rome and rule over a truly united Empire as Maximinus had done earlier, there was something unique about the experiences of northwest Europe even in the context of the turbulent third century. Crucially, the only way to draw out with any precision or clarity the exact nature of this difference and, more interestingly, what may have been the main causes of why the region experienced the period the way that it did is by comparing Gaul with a different area that underwent similar events, yet experienced them differently.

I offer in this article, then, a different look at some of the crucial factors and issues impacting the western Roman Empire during the third century AD, one of the more turbulent and problematic periods in Roman history. Certainly, it is not possible to do justice to this complex period in the short space of this article. Still, direct comparison of the key factors explored here provides a more nuanced understanding of the complex events explored as case studies in this article, highlighting the way that different aspects of Roman society progressed along different paths; how ideological and political continuities in Gaul coexisted with broad dislocations due to military, economic, and financial developments; while in Africa, deep seated ideological, economic, and financial stability were able to overcome political turmoil and civil fighting to maintain ties with the wider Roman world throughout this tumultuous period. These two important regions in the western Empire were in certain respects at once both 'outside' and 'inside' the traditional structures of imperial Roman life. Still, in order to fully understand this crucial period in the history of the Roman Empire, it is necessary to determine how the various factors-political, ideological, military, economic, and financial—affected the regions differently during this period and thereby to identify some of the deep, structural roots which underlay the divergent experiences of these two regions in the third century AD. 


\title{
Raiders to Traders? Economics of Integration among Nomadic Communities in North Africa
}

\author{
Wim Broekaert and Wouter Vanacker
}

\section{1 \\ Introduction}

Since the Augustan age, Rome progressively moved away from the North African coastline into the dusty inlands. To the various (semi)nomadic tribes pasturing their flocks within and beyond the Roman range of power, Rome's arrival entailed various political, economic and social consequences. The presence of Roman hegemony in particular had important repercussions for the traditional power balance and the nature of exchange between sedentary and (semi-)nomadic groups. While the restrictions of a pastoral economy had previously been met by raiding, pillaging and the exaction of tribute, Roman occupation provided a political and socio-economic framework which allowed alternative solutions. It has been argued before that the economic interaction between nomadic and sedentary societies cannot be reduced to hostility and predation but is also characterized by close symbiosis and interdependency. ${ }^{1}$ In this contribution however, we show that previous research seriously underestimated the intermediary role of nomads in supplying both Roman civic and military settlements and the sub-Saharan kingdoms. Pastoralist nomadic tribes duly recognized the economic potential of emerging and ever-expanding civil and military markets and took advantage of these economic opportunities by playing an important role as very mobile commercial mediators connecting the Mediterranean and the sub-Saharan regions. To analyze these patterns of exchange during the Roman imperial period, we will first present an anthropological model of interaction between nomadic and settled communities and the economic opportunities for both parties. Next, we test the applicability of the model by discussing the particular role of the Garamantes in the economy of Roman Africa. To corroborate the analysis, data on economic interaction

1 Wouter Vanacker, "Differentiated Integration Trajectories of the Nomadic Population in Roman North Africa (1st-3rd cent. AD)," in: Integration in Rome and in the Roman World. Proceedings of the Tenth Workshop of the International Network Impact of Empire (Lille, June 23-25, 2011), Stéphane Benoist, Gerda De Kleijn (eds.) (Leiden/Boston, 2013), pp. 197-216. 
with local tribes in other Roman frontier zones and, above all, anthropological research of other pre-industrial pastoral economies will be adduced to offer comparative evidence.

\section{Pastoral Nomadism(s) in North Africa}

Over the centuries, northern Africa has witnessed different types of pastoral nomadism or semi-nomadism. Contrary to common belief, these nomads do not live permanently "under the tent": they frequently migrate to herd their flocks but return to the same base camp for a certain period of the year. In mountainous regions, environmental restrictions even further reduce migrations to limited transhumance. Only the desert and pre-desert witnessed the development of modes of highly mobile pastoral nomadism with comparably less engagement in agriculture, often however being counterbalanced by a more pronounced engagement in (mediatory) trade. ${ }^{2}$ The highly differentiated environmental features of the region, characterized by the alteration of mountains, plains and desert, hence caused a plethora of migration patterns to develop. Johnson recognized at least five forms of pastoral migration in North Africa, each presenting certain peculiarities in herd composition and a specific multi-resource economic strategy. ${ }^{3}$ At least in modern times, pastoral nomadism is best described in terms of differentiation and diversity.

The question is whether this contemporary model of African pastoral nomadism can be applied to Roman times? Traditional literary evidence usually does not allow a systematic approach and subdivision in ideal types as proposed in modern anthropology and ethnography. Apart from considering the nomadic societies with contempt, Greek and Roman accounts generally fail to provide even the basic information required for a thorough analysis and characterization of the internal social, economic and governing institutions. ${ }^{4}$ Moreover,

2 See Jeffrey C. Kaufmann, "The Sediment of Nomadism," History in Africa 36 (2009), pp. $235^{-264}$.

3 Douglas L. Johnson, The Nature of Nomadism. A Comparative Study of Pastoral Migrations in Southwestern Asia and Northern Africa (Chicago, 1969), pp. 170-176.

4 On the Greek and Roman perception of nomadism, see Pol Trousset, "Villes, campagnes et nomadisme dans l'Afrique du Nord antique: représentations et réalités," in Villes et campagnes dans l'empire romain. Actes du Colloque organisé par l'U.E.R. d'Histoire, Paul A. Février, Philippe Leveau (eds.) (Aix-en-Provence, 1980), pp. 195-206; Georges Devallet, "Vagi, palantes Afri: quelques réflexions sur l'image romaine du nomade africain," in Histoire des Hautes Steppes. Antiquité-Moyen Âge, Bejaoui, Fathi (ed.) (Sbeitla, 2001) pp. 31-38; Maurice Sartre, "Les nomades dans l'Empire romain," in Le monde de l'itinérance en Méditerranée de 
ancient authors tend to reduce the pastoralist community to a stereotype of savage nomads and pillagers, with no interest whatsoever in agriculture and other aspects of sedentary societies. Tacitus' description of the Musulamii as a warmongering tribe of rogues is a good example. ${ }^{5}$ Fortunately, the one-sided nature of literary sources can now be challenged by more multifaceted archaeological datasets. Archaeological surveys suggest that peoples, who were dwelling in the North African inlands and had been described as highly mobile and non-sedentary nomadic tribes in literary sources, should actually be considered semi-nomadic groups. The ruins of the civitas Tigensium for instance have been identified as the remains of a fortified settlement of semi-nomads predating Roman occupation. ${ }^{6}$ The remains offer an idea of what could have been the 'nomadic' fortifications (pyrgoi, turres, and castella) mentioned in literary sources. ${ }^{7}$ In a similar vein, semi-nomads appear to have occupied large farmsteads with big herd enclosures for sheep and goats, but also for camels and

l'antiquité à l'époque moderne. Procédures de contrôle et d'identification, eds. Claudia Moatti, Wolfgang Kaiser, and Christophe Pébarthe (Bordeaux, 2009), pp. 58-6o; Brent D. Shaw, "Fear and Loathing: the Nomad Menace and Roman Africa," in Roman Africa (The Vanier Lectures), ed. Colin M. Wells (Ottawa, 1982), pp. 29-31; Brent D. Shaw, "Eaters of Flesh, Drinkers of Milk': the Ancient Mediterranean Ideology of the Pastoral Nomad," Ancient Society 13/14 (1982-1983); Yves A. Dauge, Le barbare: recherches sur la conception romaine de la barbarie et de la civilisation (Bruxelles, 1981), pp. 620-626; Pol Trousset, "Limage du nomade saharien dans l'historiographie," Production pastorale et société 10 (1982), pp. 101-102.

5 Cf. Tac. Ann. 2, 52.

6 Pol Trousset, "Thiges et la civitas Tigensium," in Actes du colloque organisé par l'École française de Rome sous le patronage de l'Institut national d'archéologie et d'art de Tunis, s.e., (Rome, 1987), pp. 143-167. Also see Naidé Ferchiou, "Habitats fortifiés pré-impériaux en Tunisie antique," Antiquités africaines 26 (1990), pp. 43-86. Cf. the famous description of the oasis of Tacape: Plin. N.H. 18, 51.

7 Castella: Sall. Bell. Iug. 87, 1 + 92, 5: castellum near the Mulucha river and 93, $3+6$ and 94, 3-4. These castella have also been mentioned by Pliny: Plin. N.H. 5, 1. Turres: Sall. Bell. Jug. 103, 1. Oppida: Sall. Bell. Iug. 46, 5 + 87, 1, also 89, 4 + 91, 4-9: Numidian "oppidum" Capsa; 81, $2+88$, 3 \& 21, 2 \& 101, 1 \& 102, 1: oppidum Cirta; 12, 3: oppidum Thirmida. 29, 4 and 47, 1+66, 2-3 +67, 1-3 + 68,3: oppidum Vaga; 37, 3: oppidum Suthul; arx/oppidum Zama: 56, 1/57, 1 + 59, 1 + 6o, 1 + 61, 1; oppidum Sicca (Veneria) 56, 3. Cf. finally 75, 1 + 77,1: oppidum Thala; 90,2: oppidum Laris; 100, 1: oppidis maritumis; 89, 1: oppida castellaque; 92, 3: alia oppida. Urbes: Sall. Bell. Iug. 29, 7 and 61, 1. Cf. also Verg. Aen. 4, 40-43. Diod. Sic. 3, 49 for pyrgoi as storages near sources of water. Also see the account of Caesar's African War: Bell. Afr. 2-7 (oppida and castella) and 25: on an oppidum of the Gaetulians and Cirta called the wealthiest town of the region. During the war, fields were stripped, strongholds and towns destroyed: Bell. Afr. 26. 
even cattle, pigs and horses. ${ }^{8}$ This kind of evidence has now confirmed that an oversimplified image of two mutually exclusive and incompatible worlds, viz. sedentary agriculture and pastoral nomadism, simply does not correspond to African society in Roman times. ${ }^{9}$ Nevertheless, many historians closely following the biased nature of Latin literature have failed to perceive the essentially heterogeneous character of semi-nomadic societies and economies. ${ }^{10}$

\section{3}

Interaction of Sedentary Communities and Nomads: A Model from Anthropology

Anthropological studies have shown that irrespective of the internal organization of nomadic economies, most of them are somehow (and often to a large extent) dependent on external sources of income and resources, usually procured from sedentary communities. This failure to develop an autarchic existence renders pastoral nomadic economies particularly vulnerable to temporary supply and production shocks and can lead to major reorganizations of nomadic tribal life." Various case studies have indicated that severe impoverishment can even initiate full settlement and a subsequent turn to nonpastoralist occupations. ${ }^{12}$ However, before turning to such drastic measures,

8 For instance René Rebuffat, "Recherches dans le désert de Libye," Comptes-rendus des séances de l'Académie des Inscriptions et Belles-Lettres 126, no. 2 (1982), pp. 195-197; David J. Mattingly, "New Perspectives on the Agricultural Development of Gebel and Pre-Desert in Roman Tripolitania," Revue des mondes musulmans et de la Méditerranée 41, no. 1 (1986), p. 58; René Rebuffat, "Les fermiers du désert," in L'Africa romana: atti del V convegno di studio (11-13 dicembre 1987), ed. Attilio Mastino (Sassari, 1988), p. 47f.

9 For a convincing attempt to render nomads more visible in the archaeological record, see Roger Cribb, Nomads in archaeology (Cambridge, 1991).

10 Trousset, "Villes, campagnes et nomadisme dans l'Afrique du Nord antique: représentations et réalités," p. 201; René Rebuffat and Hassan Limane, "Les confins sud de la présence romaine en Tingitane dans la région de Volubilis.," in Histoire et Archéologie de l'Afrique du Nord. Spectacles, vie portuaire, religions. Actes du Ve colloque international réuni dans le cadre du 115e Congrès national des Sociétés savantes Avignon, 1990, ed. Jehan Desanges (Paris, 1992), pp. 241-244.

11 Pavel Poucha, "Bodenbauern und Nomaden im alten Mittel- und Zentralasien," in Das Verhältnis von Bodenbauern und Viehzüchtern in historischer Sicht, ed. Irmgard Sellnow (Berlin, 1979), p. 124; A.M. Khazanov, Nomads and the Outside World (Madison, 1994), p. 122.

12 In general: Khazanov, Nomads and the Outside World, p. 83; among the Basseri in the 2oth century: Fredrik Barth, "Capital, Investment and the Social Structure of a Pastoral Nomad Group in South Persia," in Capital, Saving and Credit in Peasant Societies, 
pastoral nomads will first take recourse to various types of interaction with sedentary societies, depending on the power balance between both groups. In the context of a dominant nomadic power, resources are often obtained in predatory ways, for instance by raids on settled or other nomadic communities or through the imposition of tribute and "protection money". When power on the other hand is controlled by the sedentary community, nomads are often compelled to work as wage laborers among agriculturalists, or perform military service. ${ }^{13}$

Additionally, trade, as an economic mode of resource exchange that is less influenced by the local power balance, must be considered an important supplementary activity of many nomadic economies. The most vital incentive of exchange is the regular shortage in food supplies, even though the need for manufactured goods as well frequently stimulates interaction with settled communities. Due to technical and logistical constraints imposed by the migratory way of life, crafts and industries are usually less developed within nomadic communities, apart from occasional repairs or the production of low quality goods. ${ }^{14} \mathrm{~A}$ different way to acquire artisan products is the incorporation of settled craftsmen within the nomadic community, but these foreign artisans

eds. Raymond Firth and B.S. Yamey (London, 1964), p. 64; among the Kazakhs in the 18th century: Elizabeth E. Bacon, "Types of Pastoral Nomadism in Central and Southwest Asia," Southwestern Journal of Anthropology 10, no. 1 (1954), p. 6o; among the Kipchaks in the 12th-15th century:Ananiasz Zajackzkowski, "Das Verhältnis der nomadischen Bevölkerung zu den seßhaften Bodenbauern in der Kiptschakischen Steppe (Dest-i Kipchak) bis zum 15. Jahrhundert," in Das Verhältnis von Bodenbauern und Viehzüchtern in historischer Sicht, ed. Irmgard Sellnow (Berlin, 1979), p. 231.

13 For military service as an alternative, cf. the Al Murrah in Saudi Arabia. Donald P. Cole, "The Enmeshment of Nomads in Sa'udi Arabian Society: the Case of Al Murrah," in The Desert and the Sown. Nomads in the Wider Society, ed. Cynthia Nelson (Berkeley, 1973), p. 125 f. Hired labor as an alternative has been observed in the case of nomads involved in cotton-picking in the North White Nile region of the Sudan, cf. Abbas Mohammed, "The Nomadic and the Sedentary: Polar Complementaries—not Polar Opposites," in The Desert and the Sown. Nomads in the Wider Society, ed. Cynthia Nelson (Berkeley, 1973), p. 105. On the relations between coastal and desert Bedouin in the Western Desert in Egypt, see also Abdalla Said Bujra, "The Social Implications of Developmental Policies: a Case Study from Egypt," in The Desert and the Sown. Nomads in the Wider Society, ed. Cynthia Nelson (Berkeley, 1973), p. 147.

14 On the particularities of crafts and industries among nomads, cf. Xavier de Planhol, "Smallscale Industry and Crafts in Arid Regions," in Arid Lands: a Geographical Reappraisal, ed. Edwin S. Hills (London, 1966), pp. 273-285. 
are usually considered alien and even marginalized groups. ${ }^{15}$ Finally, trade also supplies nomadic elites with luxurious consumption goods. ${ }^{16}$ These demands often force nomads to engage in direct exchange, either selling their own products directly to city-dwellers and agriculturalists, or through the intervention of sedentary merchants. Major commercial opportunities can even influence the trajectories nomads chose for pastoral migration. However, due to restrictions imposed by migration and the difficulties in generating a regular surplus destined for the market, direct exchange frequently fails to develop into a permanent commercial system profitable for both parties. ${ }^{17}$

These practical limitations are largely met by a considerable engagement in mediatory trade, a useful concept developed by Khazanov to denote the commercial links forged by nomads between sedentary communities. ${ }^{18}$ Their mobility and experience in herding animals along far-reaching land routes allowed nomads to establish exchange connections between otherwise isolated communities, without at the same time becoming full-fledged merchants or abandoning the nomadic way of life..$^{19}$ Especially for Saharan nomads the caravan trade was for centuries the most important economic activity. The Tuareg of the Aïr for instance not merely commanded the exchange of salt, iron, ostrich feathers and other products between West and North Africa, but also organized the grain trade between desert oases and the agriculturalists of

15 See for instance the tribes of the Rif, where the lower social status of the so-called imazilen or "Shameless Ones" is based upon their engagement in blacksmithing and piping or the exercise of certain public professions (public criers, measurers and weighers in markets). See Carleton S. Coon, Tribes of the Rif(Cambridge, Mass., 1931), p. 92f. Separate castes based on occupation have been noticed in Arabian region of Southwest Asia as well. For the lower status of blacksmiths in this region, see Bacon, "Types of Pastoral Nomadism in Central and Southwest Asia," p. 64. Among the Tuareg, the ikanawen or potters and the inadan or blacksmiths form notable examples of incorporated artisan castes. Cf. de Planhol, "Small-scale Industry and Crafts in Arid Regions," pp. 278-279.

16 Jürgen Paul, "Perspectives nomades: état et structures militaires," Annales. Histoire, Sciences Sociales 59, no. 5/6 (2004), p. 1074.

17 Khazanov, "Nomads and the Outside World," pp. 202-209.

18 On nomads and mediatory trade in general, cf. Ibid., pp. 209-212. In 19th and early 2oth century Russia among the Negidals: Sergej V. Ivanov, Maksim G. Levin, and Anna V. Smolyak, "The Negidals," in The Peoples of Siberia, eds. Maksim G. Levin and Leonid P. Potapov (Chicago/London, 1964), p. 690.

19 Paul E. Lovejoy and Stephen Baier, "The Desert-Side Economy of the Central Sudan," in The Politics of Natural Disaster. The Case of the Sahel Drought, ed. Michael H. Glantz (Washington/New York/London, 1976), p. 153; V.V. Khramova, "The West-Siberian Tatars," in The Peoples of Siberia, eds. Maksim G. Levin and Leonid P. Potapov (Chicago/London, 1964), pp. 426-427. 
the southern Sahel. ${ }^{20}$ Trade stations and marketplaces were even located along migration trajectories to keep transport costs relatively low. ${ }^{21}$ The control of trade routes through the Sahara was their main political concern. In return for their mediatory participation, the nomads received slaves, manufactured goods and corn. ${ }^{22}$ Similar nomadic engagement in caravan trade (though in non-desert areas) has already been documented for antiquity, for instance among the Scythians and Sarmatian Aorsians. ${ }^{23}$

\section{$4 \quad$ Frontiers and Beyond: Mediatory Trade and the Garamantes}

The anthropological model of nomadic economies discussed above provides a valuable starting point for the discussion of exchange patterns used by nomads in Roman Africa. What effect did Roman political power have on the sedentary-nomadic power balance and, consequently, on the pastoral nomadic economy itself? How did pastoral nomadism develop under Roman rule within and beyond the frontiers? Can we trace nomadic engagement in trade, either mediatory or direct, and to what extent could this have been sparked off by the increase of settled communities and commercial opportunities in the frontier zone?

Before turning to the actual analysis of exchange patterns, two common misconceptions need to be addressed. First, the virtual absence of accounts on trans-Saharan trade in Greek and Latin literature cannot be a valuable argument to discard the possibility of large-scale commercial contacts between Roman and sub-Saharan territory. ${ }^{24}$ Archaeological studies in the Fazzan and in the sub-Sahara have shown that indigenous groups from the Sahara, such as the Garamantes, were the mediators of an ever increasing exchange between Mediterranean and sub-Saharan markets. Of major importance is the discovery of sub-Saharan goods within Garamantian territory, as well as Garamantian trade stations far to the south of the tribe's capital, exactly in places that were

\footnotetext{
20 Lovejoy and Baier, "The Desert-Side Economy of the Central Sudan," p. 15of.

21 Ibid., 152-153.

22 Irmgard Sellnow, "Der Einfluß von Nomaden auf Wirtschaft und Politik der Hausastaaten," in Das Verhältnis von Bodenbauern und Viehzüchtern in historischer Sicht, ed. Irmgard Sellnow (Berlin, 1979), pp. 194-195.

23 Her. 4, 24. Strabo 11, 5, 8.

24 Pekka Masonen, "Trans-Saharan Trade and the West African Discovery of the Mediterranean," in Ethnic Encounter and Culture Change. Papers from the Third Nordic Conference on Middle Eastern Studies, Joensuu (June 1995), ed. M'hammed Sabour, Knut S. Vikør (Bergen/London, 1997), pp. 116-142.
} 
to become important trade centers in later times. Saharan tribes indeed played an important role in connecting the estimated 5 million inhabitants of the southern pre-desert and the Sahel with the Mediterranean world. ${ }^{25}$ This evidence clearly refutes the idea of trans-Saharan trade in Roman times as "one of the most elusive myths of African history". ${ }^{26}$ Second, the establishment of a Roman frontier never really complicated or reduced exchange. It has rightly been argued that in North Africa, the frontier zone is best understood as a permeable structure designed at the control through canalization of cross-frontier (including pastoral) migrations. ${ }^{27}$ Archaeological, epigraphic and literary evidence has shown that, rather than being a 'closed frontier', the limes was continuously crossed by migrant pastoralists and traders whose goods the Romans were eager to tax. In fact, the permeability of the frontier system combined with the rise of urban and military markets effectively stimulated commercial

25 Estimated by Colin McEvedy, The Penguin Atlas of African History (Harmondsworth, 1983), p. 36 .

26 John T. Swanson, "The Myth of Trans-Saharan Trade Dring the Roman Era," The International Journal of African Historical Studies 8, no. 4 (1975), p. 582. Cf. also Mamadou L. Nabé, "Schwarzafrika südlich der Sahara und die Antike," Das Altertum 16 (1970), pp. 10-17.

27 Sebastian Matz, "Befestigung im Nirgendwo," Antike Welt 38, no. 1 (2007), pp. 55-59; René Rebuffat, "Mobilité des personnes dans l'Afrique romaine," in La mobilité des personnes en Méditerranée de l'Antiquité à l'époque moderne: procédures de contrôle et documents d'identification, ed. Claudia Moatti (Rome, 2004), pp. 156-203; Pol Trousset, "Le tarif de Zaraï: essai sur les circuits commerciaux dans la zone présaharienne," Antiquités africaines 38-39 (2002-2003), pp. 355-373; Pol Trousset, "Nouvelles barrières romaines de contrôle dans l'extrême sud tunisien," Bulletin archéologique du Comité des travaux historiques et scientifiques. Série B, Afrique du Nord 24 (1997), pp. 155-163; David J. Mattingly, Tripolitania (London, 1995), p. 79f.; Christine Hamdoune, "Géographie et administration de la Maurétanie Tingitane: ad fines imperii Romani, Mauretania Tingitana," L'information historique 53 (1991), pp. 127-133; Maurice Euzennat, Le limes de Tingitane. La frontière méridionale (Paris, 1989); Michel Janon, "Paysans et soldats," in Roman Africa (The Vanier Lectures), ed. Colin M. Wells (Ottawa, 1982), pp. 51-67; Pol Trousset, "Signification d'une frontière: nomades et sedentaires dans la zone du limes d'Afrique," in Roman Frontier Studies 1979: Papers Presented to the 12th International Congress of Roman Frontier Studies, ed. Lawrence J.F. Keppie, William S. Hanson (Oxford, 1980), pp. 931-943; Pol Trousset, Recherches sur le limes tripolitanus (Paris, 1974); Maurice Euzennat, "Recherches récentes sur la frontière d'Afrique (1964-1974), II," in Studien zu den Militärgrenzen Roms, II: Vorträge des 10. Internationalen Limeskongresses in der Germania Inferior, Xanten, 1974, eds. Dorothea Haupt, Heinz G. Horn (Xanten, 1974), pp. 429-443; Maurice Euzennat, "La frontière romaine d'Afrique," Comptes Rendus de l'Académie des Inscriptions et Belles-Lettres 134, no. 2 (1990), p. 580; Mario Liverani, "Imperialismo, colonizzazione e progresso tecnico. Il caso nel Sahara libico in età romana," Studi storici 47, no. 4 (2006), p. 1033. 
exchange with Saharan peoples. These developments will be discussed in more detail in the following sections, by focusing on the Garamantian economy as a case study.

Traditionally, the Garamantian pastoral economy has been described as dominating the trans-Sahara trade between Roman territory in the north and African kingdoms in the south. ${ }^{28}$ In this triangular trade pattern, it has frequently been argued that the Garamantes focused on exporting salt to the subSaharan area in exchange for gold and slaves, who allowed the use of slave labor in the Garamantian homeland but were also re-exported to Roman markets, and importing Mediterranean ceramics, glassware and food in return. ${ }^{29}$ This model however covers only part of the Garamantian economy and neglects both the export potential of locally produced wares well-documented in the archaeological records and their crucial role as mediatory traders. Far more commercial opportunities in the southern and northern markets therefore need to be taken into account. The following sections will discuss several markets the Garamantes were supplying and the sometimes remarkable range of goods. As literary sources usually are silent about the nature of merchandise being transported by nomadic peoples and epigraphy offers only little help, we explore the various opportunities available to the Garamantes and adduce comparative evidence, both from antiquity and other nomadic societies, to add weight to our analysis.

28 D.J. Mattingly, ed. The Archaeology of Fazzān. Vol. I. Synthesis (Tripoli, 2003), p. 277.

29 Cf. Robin C.C. Law, "The Garamantes and Trans-Saharan Enterprise in Classical Times," The Journal of African History 8, no. 2 (1967), p. 195; Mario Liverani, "The Libyan Caravan Road in Herodotus IV.181-185," Journal of the Economic and Social History of the Orient 43, no. 4 (2000), pp. 507-508; Mario Liverani, “The Garamantes: a Fresh Approach," Libyan Studies 31 (2000), p. 20; Liverani, "Imperialismo, colonizzazione e progresso tecnico. Il caso nel Sahara libico in età romana," p. 1019; David J. Mattingly, "Twelve Thousand Years of Human Adaptation in Fezzan (Libyan Sahara)," in The Archaeology of Drylands. Living at the Margin, eds. Graeme Barker, David Gilbertson (London/New York, 2000), p. 172; Efthymia Nikita, David Mattingly, and Marta M. Lahr, “Sahara: Barrier of Corridor? Nonmetric Cranial Traits and Biological Affinities of North African Late Holocene Populations," American Journal of Physical Anthropology 147 (2011), p. 280; Andrew Wilson, "The Spread of Foggara-based Irrigation in the Ancient Sahara," in The Libyan Desert: Natural Resources and Cultural Heritage, eds. David J. Mattingly et al., (London, 2006), p. 206. 


\section{$5 \quad$ The Military Market}

The triangular trade pattern discussed above severely underestimates the opportunities offered by the military supply to Roman garrisons (see Figure 6.1 and Figure 6.2). It is well-known from the ostraca discovered in Bu Njem that the Garamantes were providing barley, mules and donkeys to the Roman garrisons. ${ }^{30}$ Yet, considering the specific production in the Garamantian kingdom and the frequent interaction between the Roman military and pastoral nomads, it seems very likely the supply of merchandise was not confined to these products alone. Local tribes must have recognized the economic advantages of the continuing soldierly demand and the proximity of a rather stable market. The picture emerging from the Bu Njem ostraca indeed suggests recurrent contacts and a more than superficial acquaintance of the Roman garrison with the native tribes along the frontier zone.

Several ostraca document how soldiers were being dispatched to a nearby customs house (statio camellariorum), where they offered assistance in collecting the tax camel drivers were obliged to pay. ${ }^{31}$ Their continued presence in this essentially civil context of frontier economies no doubt stimulated a certain

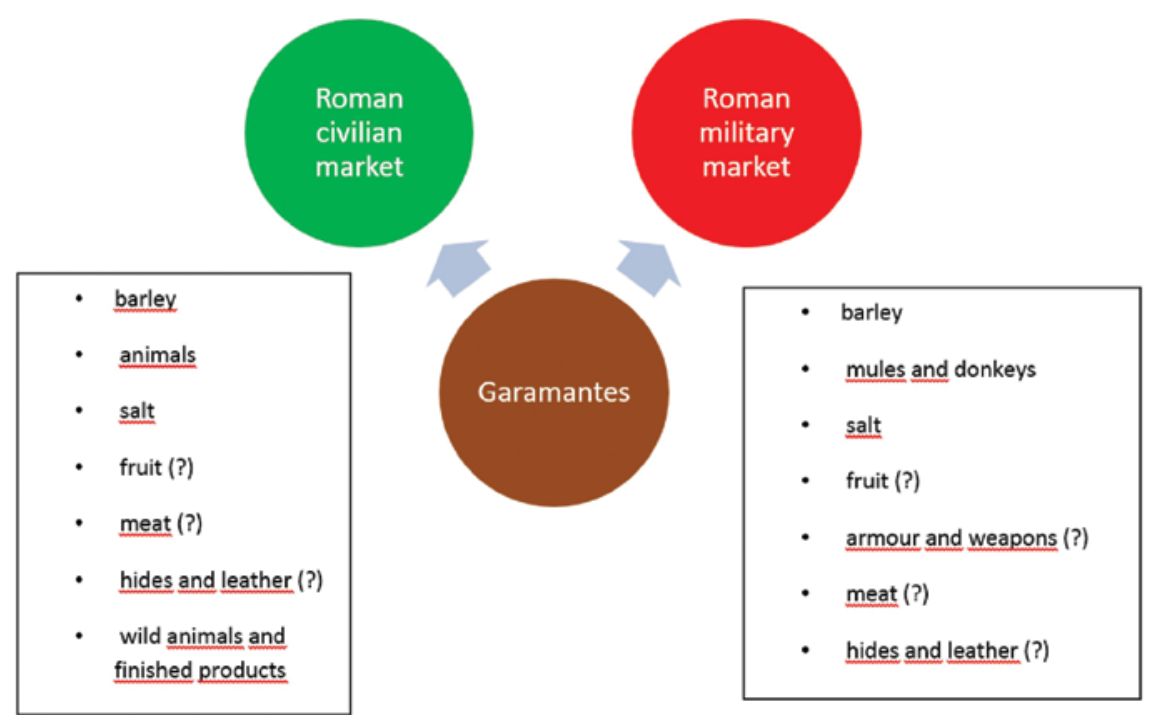

FIGURE 6.1 Export to northern regions.

$30 \quad$ O. Bu Njem $71-72$.

31 O. Bu Njem 3-5; 8-10 and 42. See Robert Marichal, Les ostraca de Bu Njem (Tripoli, 1992), pp. 112-113. It should be noted however that statio can also refer to a unit of camel riders, 


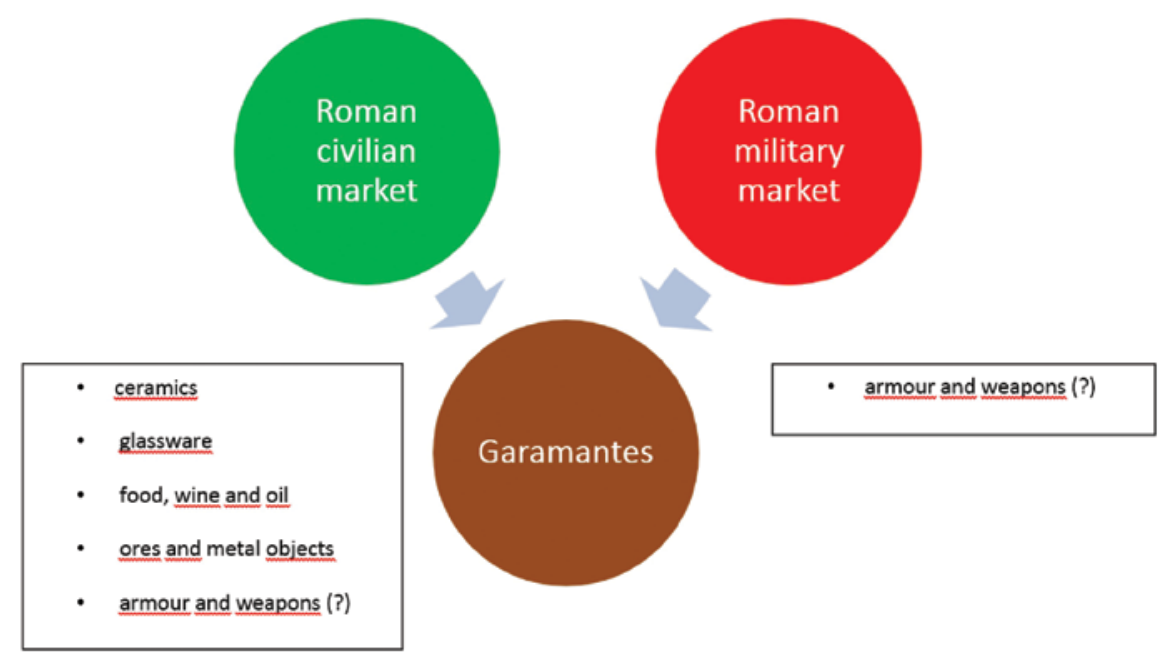

FIGURE 6.2 Imports from northern regions.

familiarity with the camellarii, especially because the dates on the ostraca indicate that caravans were passing through the customs house on a regular basis, viz. once every two days. This familiarity is reflected in another series of ostraca, indicating that the Roman military was regularly making use of the transport services offered by the native camellarii. ${ }^{32}$ Particularly interesting is the fact that measures of the imported goods are often cited in native languages and that different indigenous names are used for a single unit. Apparently the origin of the camellarius and his mother tongue determined the specific terminology, implying not only that the military relied on the services of different tribes, but also that the soldiers of the garrison were sufficiently acquainted with these local measures to use them in administrative documents. The latter clearly points to the frequency of interactions. The Garamantian caravans were also involved in the diffusion of information, for one ostracon reports that they had brought letters to the garrison. ${ }^{33}$ The nature of these litterae is still debated on. Marichal assumes they may have been letters of recommendation, written

which completely alters the meaning of the ostracon. A similar reference is found in P. Mich. Inv. 2758 \& 2761 .

32 O. Bu Njem 76-81 and 88. Ibid., 100-101. The camel drivers have either Punic (Iddibal and Macargus) or Libyan (Iassuchtan and Iaremaban) names. Johannes Kramer, Vulgärlateinische Alltagsdokumente auf Papyri, Ostraka, Täfelchen und Inschriften, vol. 23 (Berlin/New York, 2007), pp. 76-77. 
by officers from a neighboring garrison, for he claims it would be odd to entrust the Garamantes with confidential correspondence. ${ }^{34}$ However, as the ostraca discussed above clearly indicate that the military frequently made use of the services offered by the Garamantian caravans, one may wonder whether the camellarii still needed an introduction. Moreover, would this kind of letters be mentioned in an ostracon as part of the garrison's administration? Entrusting letters to the Garamantian camel drivers may quite easily be the simplest solution to quickly diffuse information. Especially when the content of the letters does not discuss military affairs or decision-making, these could without much 'danger' be entrusted to the Garamantes. We only have to consider some of the letters discovered in Vindolanda to get an idea of the fairly innocent correspondence passing through military camps, such as the invitation to a birthday party or the request to send some hunting nets. ${ }^{35}$

A final aspect of the continuing interaction shows a Roman soldier escorting Garamantes. ${ }^{36}$ The exact purpose is still unclear. Did the military hope to start negotiations with Garamantian tribes? Or were soldiers obliged to accompany people who were living outside the frontier upon entrance within the empire, as described by Tacitus and Dio Cassius? ${ }^{37}$ If the latter were true and Garamantian and other pastoralists' caravans were constantly crossing the border to do business, then the soldiers of Bu Njem must have familiarized very quickly with the caravan people. The close involvement of the Roman beneficiarii in monitoring customs as indicated by the Lambaesis tariff also points to regular interaction between the military and pastoralists frequenting local markets. ${ }^{38}$

Thus, the many opportunities for personal contact and continuous interaction must have created a mental environment of trust and familiarity and hence stimulated economic exchanges between the pastoralist communities and the Roman military. This is not a particularly earth-shattering observation, as comparative evidence from the northern frontier zone similarly identifies the involvement of the Roman military in cross-frontier exchange. In Pannonia superior for instance, a centurio of the $15^{\text {th }}$ legion acting as an interpreter and merchant most likely organized the import of merchandise produced by tribes

34 Marichal, Les ostraca de Bu Njem: 111.

35 Vindolanda tablet 291 and 233 respectively.

36 O. Bu Njem 28.

37 Tac. Ann. 4, 64; Dio Cass. 73, 2, 4. See also Augustinus Ep. 46.

$38 \quad A E$ 1914, 234. 
living across the border and unfamiliar with Latin language. ${ }^{39}$ We therefore argue that the commercial contacts between the frontier garrisons and tribal communities outside the empire were probably far more intense than textual and archaeological sources allow us to detect. We now focus on the various goods the Garamantes may have supplied to the Roman military.

First, industrial residues from the Jarma area and other areas of the Fazzan have identified a thriving salt extraction industry, producing one of the key commodities of the traditional model of exchange. ${ }^{40}$ Salt however was not only in demand in the southern sub-Saharan kingdoms, but could also be exported to the northern markets, as salt was a main ingredient of the military diet. It added flavor to various meals and facilitated food storage by reducing perishability of a wide range of victuals such as meat, fish and vegetables. Moreover, salt belonged to the soldiers' rations supplied by the military, so merchants specializing in this particular product were always certain to find a stable and predictable market. ${ }^{41}$ Because of these favorable trading conditions, salt production and commerce was very often located in the near vicinity of frontier zones. Along the northern limes for instance, salt extraction has been documented along the Belgian and southern English coastline. ${ }^{42}$ Distribution to the military markets was organized by the Morini and Menapii in particular, for salt-dealers belonging to these tribes initiated two honorary inscriptions for L. Lepidius Proculus, a centurio primuspilus who had served in Neuss, a military settlement along the Rhine frontier. ${ }^{43}$ It seems very likely they had been supplying his garrison with salt. Evidence of maritime and riverine salt trade is supplied by a range of dedicatory inscriptions of salt-dealers found near Colijnsplaat, a sanctuary situated in the Scheldt estuary and dedicated

$39 A E$ 1978, 635. See Titus Kolník, "Q. Atilius Primus, interpres centurio und negotiator. Eine bedeutende Grabinschrift aus dem 1. Jh. u. Z. im quadischen Limes-Vorland," Acta Archaeologica Academiae Scientiarum Hungaricae 30 (1978), pp. 61-75. Mattingly, The Archaeology of Fazzān. Vol. I. Synthesis, pp. 118 and 359. Ground stone tools found in Garamantian settlements were possibly used to crush blocks of salt. Lucia Mori, "The Ground Stone Tools," in Aghram Nadharif. The Barkat Oasis (Sha'Abiya of Ghat, Libyan Sahara) in Garamantian Times, ed. Mario Liverani (Firenze, 2005), p. 284.

41 S. Perea Yébenes, "El uso de la sal en el ejército romano y su abastecimiento en época altoimperial," in Arqueología militar romana en Hispania II : producción y abastecimiento en el ámbito militar, ed. A. Morillo Cerdán (León, 2006), pp. 354-359.

42 Curtis, Robert I. Garum and Salsamenta: Production and Commerce in Materia Medica (Leiden, 1991), pp. 79-80; Hugo Thoen, "Zoutwinning: de teloorgang van een antieke industrie langs de Vlaamse Kust," in Met zicht op zee, ed. Jean-Luc Meulemeester (Tielt, 2000), pp. 11-14. 
to the indigenous goddess Nehalennia. ${ }^{44}$ She was worshipped in particular by businessmen crossing the Channel and sailing the North Sea, the Rhine and Scheldt during the late 2nd and early 3 rd century and organizing the supply of British and German military markets. ${ }^{45}$ A very similar trading pattern may have developed along the African frontier. As we have no evidence of salt production in the settlements close to the limes, salt refined in Garamantian territory may well have been a major import product. Literary sources confirm the material evidence of salt production in the Sahara and among the Garamantes in particular. ${ }^{46}$

Yet, salt may not have been the only ingredient of the military diet produced and exported by the Garamantes. One of the Bu Njem ostraca notes the arrival of a donkey laden with suriacas. ${ }^{47}$ In the first edition, Marichal identified this merchandise as Syrian textiles, without however offering an explanation for his suggestion or contextualizing the presence of Syrian goods on the southern African limes. ${ }^{48}$ One may rightly wonder how and why these goods had ended up among the merchandise transported by a pastoralist caravan and which customers they were hoping to find in a military garrison. More recent accounts of the African caravan economy equally struggled with this remarkable document, but adhered to Marichal's interpretation. ${ }^{49}$ Nevertheless, a fragment of Pliny's Natural History can help to elucidate the word suriacas or at least present a more plausible interpretation. In his description of trees, Pliny mentions the myrobalanum, a tree commonly found in Arabia, the Thebais and the land of the Troglodytae, viz. an African region very close to the Garamantian territory. ${ }^{50}$ The fruit has been identified as the behen or ben nut, the fat and soft kernel of which can be consumed, but is far more frequently used for oil extraction, as indicated by its unequivocal scientific name Moringa oleifera. Interestingly, Pliny adds that the Arabian kind was called syriaca. If this name also applied to the African variety, which admittedly Pliny fails to specify, then the ostracon would merely record the import of a locally produced fruit as an addition to the military diet. As Pliny in another fragment

\footnotetext{
$44 \quad A E$ 1973, 362; $A E$ 1973, 364 and $A E$ 1973, 378.

45 Petrus Stuart and Julianus E. Bogaers, Nehalennia, Römische Steindenkmäler aus der Oosterschelde bei Colijnsplaat (Leiden, 2001).

46 Cf. the many attestations in Herodotos: Her. 4, 181-185 and especially 183 among the Garamantes. Plin. N.H. 5, 34 .

$47 \quad$ O. Bu Njem 73.

48 Marichal, "Les ostraca de Bu Njem," p. 111.

49 Mattingly, "Tripolitania," p. 157. "a consignment of cloth (syriacas) though both its origin and destination are unclear".

$50 \quad$ Plin. N.H. 12, 101.
} 
lauds the lusciousness of fruits and other crops cultivated by the Garamantes and botanical remains are now able to corroborate his descriptions, it seems at least possible that the Garamantes were supplying the garrison with fresh fruits. ${ }^{51}$ Moreover, significant fruit cultivation by the Garamantes is also suggested by the manifold discoveries of date stones and other fruit remains in funerary contexts in the Wadi al'Ajal (Zinkekra cemetery), while the regional consumption of dates is further affirmed by the presence of date pits in waste contexts at Ghirza, Aghram Nadharif and in the grave chamber of the Abalessa monument. ${ }^{52}$

Next, various sites in the Fazzan, and Saniat Jibril in particular, have yielded archaeological evidence of metalworking, such as iron slags, copper-alloy fragments, ingot molds and hearths. ${ }^{53}$ The Garamantes clearly disposed of iron and copper ore and seem to have produced a variety of domestic products and tools. Yet, we cannot exclude that part of the production of metal objects was also aimed at military markets. So far, we have no evidence of Garamantes engaging in the production of weaponry or armor, but research of African metallurgy is

$5^{1}$ Plin. N.H. 13, 111 and David J. Mattingly, "Early Libyan State with Trans-Saharan Connections," in Money, Trade and Trade Routes in Pre-Islamic North Africa, eds. Amelia Dowler and Elizabeth R. Galvin (London, 2011), p. 53.

$5^{2}$ Zinkekra: David Mattingly et al., "Desert migrations: people, environment and culture in the Libyan Sahara," Libyan studies 38 (2007), p. 137 and 141. Ghirza: Olwen Brogan, D.J. Smith, Ghirza. A Libyan Settlement in the Roman Period (Tripoli, 1984), p. 97. Also see Plin N.H. 13, 111, on date production in the African interior up to the lands of the Garamantes. Generally, in the Tripolitanian pre-desert: Mattingly, "New Perspectives on the Agricultural Development of Gebel and Pre-Desert in Roman Tripolitania," p. 57; Rebuffat, "Les fermiers du désert," p. 56. In Aghram Nadharif: Anna Maria Mercuri et al., "The Archeobotanical Remains (Pollen, Seeds/Fruits and Charcoal)," in Aghram Nadharif. The Barkat Oasis (Sha'Abiya of Ghat, Libyan Sahara) in Garamantian Times, ed. Mario Liverani (Firenze, 2005), pp. 335-348. Abalessa monument (dated to the early fourth century AD): Gabriel Camps, "Le tombeau de Tin Hinan à Abalessa," Travaux de l'Institut de Recherches Sahariennes 24 (1965), p. 69.

53 Mattingly, "The Archaeology of Fazzān. Vol. I. Synthesis," p. 356. David J. Mattingly, ed. The Archaeology of Fazzān. Vol. II. Site Gazetteer, Pottery and Other Survey Finds (Tripoli, 2007), pp. 448-462 (overview). Mattingly, "The Archaeology of Fazzān. Vol. I. Synthesis," p. 121 (Jarma area), p. 125 (al-Hatiya oasis zone); David J. Mattingly, ed. The Archaeology of Fazzān. Vol. III. Excavations carried out by C.M. Daniels (Tripoli, 2010), p. 197 (Saniat Jibril). Also at Aghram Nadharif, see Mario Liverani, "Looking for the Southern Frontier of the Garamantes," Sahara 12 (2000), p. 43. Abalessa: Camps, "Le tombeau de Tin Hinan à Abalessa," p. 69. 
notoriously limited. ${ }^{54}$ Comparative evidence from the northern limes however confirms the existence of a lucrative trade in weapons and armor along the frontiers in addition to the production controlled by the army. ${ }^{55}$

Finally, the availability of large herds allowed the production of a wide variety of products which could be supplied to military markets. The documents from $\mathrm{Bu}$ Njem so far only refer to Garamantes importing live animals, but a range of by-products of pastoral economies may have been sold to the military as well..$^{56}$ We can first imagine that part of the meat provided by slaughtered animals was being processed into salted or dried meat. As salt extraction was a main constituent of the Garamantian economy, all ingredients to allow the production and merchandizing of salted meat were present. The regular supply of meat proved to be a major opportunity for merchants, as even though the calories from animal sources were only marginal compared to cereals, meat nevertheless was included in the ancient military diet. ${ }^{57}$ Yet large-scale animal husbandry demanded less densely populated areas in which the flocks could be grazed, which may pose a problem for less fertile regions, as animals, people and arable agriculture compete for the same lands. With semi-nomadic pastoralists focusing on breeding cattle on the outskirts of the empire and beyond, the core area with the large agricultural estates had the ability to specialize in cereals and cash crops such as oil and wine and leave the supply of meat to tribes such as the Garamantes.

Moreover, pastoral economies provided for a large supply of secondary pastoral products such as hides, which could be used for leather processing, an industry which may have been particularly important to the Garamantian society as substantial quantities of alum occurred in the Fazzan. ${ }^{58}$ This specific salt was used as a mordant in the leather production process. It is obviously well-known that within a military context, demand for leather was extremely high, as it was employed for tents, armor, footwear, slings, shield covers, horse gear etc. Moreover, leather products easily wore out, which created a constant and large demand for the material. Herz for instance guesstimated that nearly

54 Copper production in the western (Akjoujt, Mauritania) and southern (Agades region) Sahara has been dated as early as the middle of the first millennium BC. John E.G. Sutton, "West African Metals and the Ancient Mediterranean," Oxford Journal of Archaeology 2 (1983), pp. 184-185.

55 R. MacMullen, "Inscriptions on Armor and the Supply of Arms in the Roman Empire," American Journal of Archaeology 64 (1960), pp. 23-40.

56 For the obvious trade in live animals, see the various species mentioned in the tariffs of Zaraï $(C I L ~ 8,4508)$ and Lambaesis (AE 1914, 234).

57 Roy W. Davies, “The Roman Military Diet," Britannia 2 (1971), pp. 122-142.

$5^{8}$ Mattingly, "The Archaeology of Fazzān. Vol. I. Synthesis," p. 360. 
30,000 calves or an equivalent of 70,000 goats was needed to provide a legion with sufficient leather to make tents. ${ }^{59}$ Roman military numbers present in the vicinity of the Garamantes did evidently not amount to the numbers of a legion, but according to an estimate from Vindolanda, even a small auxiliary unit still needed 3,360 goatskins for leather tents alone. ${ }^{60}$ The figures can hence offer an idea of the animal numbers required for military equipment. The involvement of African pastoralists in leather industry and commerce can also be deduced from the recurrence of leather products in the Zarai tariff. 61 Moreover, comparative evidence from the northern frontier confirms the high demand for hides and leather and the reliance on tribes along the frontier to organize supplies. ${ }^{62}$ Tacitus for instance relates how the Frisons, a subdued nation living beyond the Rhine, had to deliver ox skins for military uses. ${ }^{63}$ In Vindolanda, hundreds of hides were being delivered to the garrison for further processing. ${ }^{64}$ The fort and the vicus of this site also provide the single largest concentration of Roman leather in Britain. However, the fact that most of these products are archaeologically virtually invisible hampers the analysis of these exchange patterns.

\section{Civilian Markets}

Second, civilian markets also benefitted from the fact that pastoral economies always are a major provider of raw materials for the textile industry (see Figure 6.1 and Figure 6.2). We already mentioned the importance of leather, but the Zaraï tariff also notes the exchange of woolen fleeces (pellem ovellam). Wool provisioning by pastoralists definitely proved to be very advantageous for arable agriculture, because animal husbandry often set high demands on estate-owners. The animal needs included sufficient grazing lands, water resources and shelter, which, especially in arid and semi-arid climate zones, few environments could provide throughout the year. The competition

59 Peter Herz, "Der Aufstand des Iulius Sacrovir," Laverna 3 (1992), pp. 42-93.

60 <http://vindolanda.csad.ox.ac.uk/exhibition/army-4.shtml> (accessed on 09/12/13).

$61 \quad C I L$ 8, 4508 (lex coriaria).

62 Carol van Driel-Murray, "The Production and Supply of Military Leatherwork in the First and Second Centuries AD: a Review of the Archaeological Evidence," in The Production and Distribution of roman Military Equipment, ed. M.C. Bishop (Oxford, 1985), pp. 43-81.

63 Tac. Ann. 4.72.

$64 A E$ 1990, 671. Alan K. Bowman, J. David Thomas, and James N. Adams, The Vindolanda writing-tablets (tabulae Vindolandenses II) (London, 1994), pp. 321-329. 
between animals and cash crops for space and water may thus work out badly for sheep. However, with flocks of sheep being kept by semi-nomads ensuring a regular water supply during summer by transhumance and wool apparently being exchanged in more urbanized regions, there was no need to allocate a considerable part of the available agricultural land to sheep-rearing and growing fodder in a mixed agriculture. Instead, as part of the raw materials would be imported by pastoralists, estate-owners had the opportunity to specialize in the production of goods destined for the Mediterranean markets and Rome in particular, viz. wine, oil and grain.

Civilian markets possibly also obtained wild animals from the Garamantes, although the trans-Saharan journey naturally seems to be a major obstacle for many sub-Saharan species. ${ }^{65}$ Nevertheless, a few texts provide evidence for a Garamantian role in the trade in wild beasts and their secondary products. The geographer Ptolemaeus commemorates the journey of a certain Iulius Maternus, otherwise unknown, who travelled with the Garamantian king to a destination called Agisymba, a name which appears to be a bantu phrase meaning 'land of the lion'.66 The discovery within Garamantian territory of bracelets made of ivory may point to the presence of a local ivory industry. 67 Moreover, a trans-Saharan ivory trade may have been stimulated by the rapid decline in northern Africa of the elephant population, due to a combination of increasing climatic desiccation and excessive hunting. ${ }^{68}$

\section{The Sub-Saharan Markets}

Turning now to the markets in the south, we again argue that the range of products exported by the Garamantes to the sub-Saharan kingdoms may have

65 For the trade in African animals, see François Bertrandy, "Remarques sur le commerce des bêtes sauvages entre l'Afrique du Nord et l'Italie (II ' s. av. J.C.-IV e s. ap. J.C.)," Mélanges de l'École française de Rome. Antiquité 99, no. 1 (1987), pp. 211-241.

66 Ptol. 1, 8, 4. On the bantu phrase, cf. Serena Bianchetti, "Esplorazioni africane di età imperiale (Tolomeo, Geogr., I, 8, 4)," in In: L'Africa romana. Atti dell'XI convegno di studio (Cartagine, 1994), eds. Mustapha Khanoussi, Paola Ruggeri and Cinzia Vismara (Sassari, 1996), pp. 355-356.

67 Mattingly, "The Archaeology of Fazzān. Vol. I. Synthesis," p. 360.

68 Lucianus (De Dips. 2) mentions elephant hunting by the Garamantes. Diminishing ivory supplies are noted by Pliny (N.H. 8, 7). Elephants were however not completely absent from North Africa (Plin. N.H. 5, 5 and 12 and also18 and 26 + 8, 31-32 and 35; Strabo 17, 3, 4-5 and 7-8; Front., Strat. 4, 7, 18; Aelian. N.A. 14, 5-6; Pomp. Mela Chor. 3, 104). Elephant tusks as votive gifts: IRT 295 and $I R T 231$ (from Lepcis Magna and Oea, respectively). 
included other merchandise than salt alone (see Figure 6.3 and Figure 6.4). It has already been noted that foodstuffs, textiles and beads produced in Garamantian territory eventually reached the sub-Saharan regions, but we probably have to revise the scale of these commercial contacts. ${ }^{69}$ The recent archaeological project at Kissi (Burkina Faso) can be a good case in point.

According to the traditional triangular trade model, this region was mainly exporting gold from the Sirba gold fields and probably also (the archaeologically less visible) black slaves to northern markets in exchange for a large variety of goods. The sub-Saharan kingdoms probably closely cooperated with the Garamantes in the procurement of sufficiently large quantities of slaves,

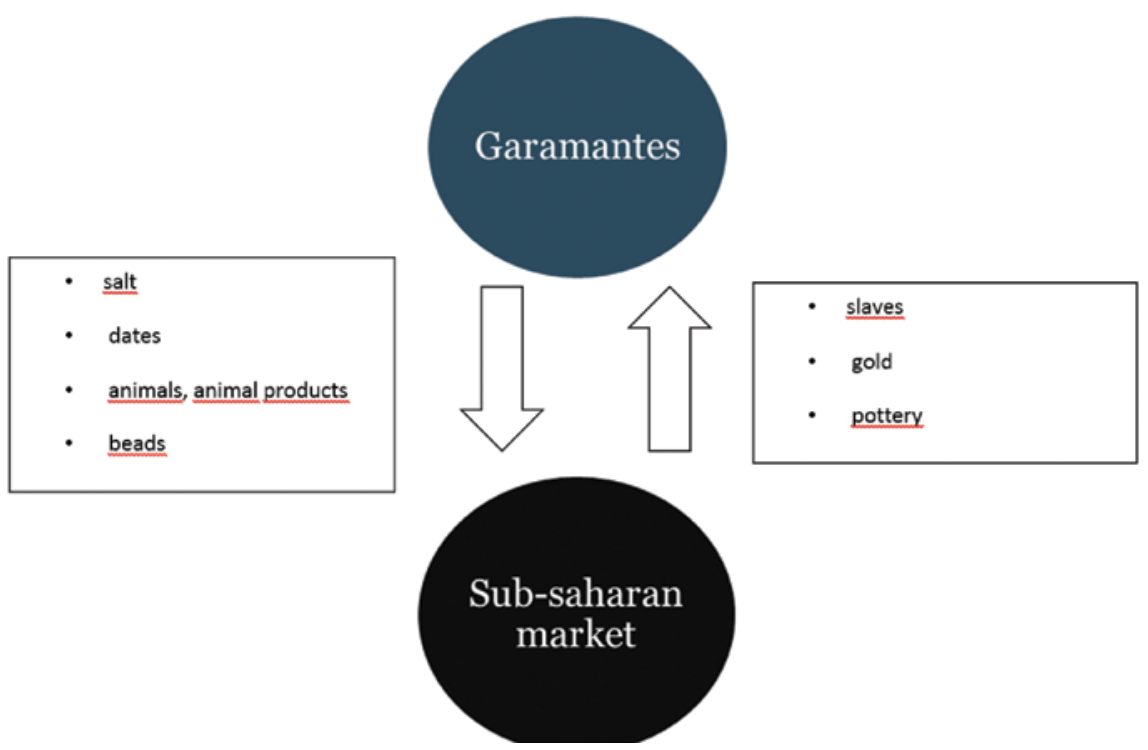

FIGURE 6.3 Exchange with southern regions.

69 Mattingly, "Early Libyan State with Trans-Saharan Connections," p. 57. MacDonald lists the potential trading partners in the south. Kevin C. MacDonald, "Sub-Saharan Evidence for Contacts between North Africa, Mauritania and the Niger, 1000 BC-AD 700," in Money, Trade and Trade Routes in Pre-Islamic North Africa, eds. Amelia Dowler, Elizabeth R. Galvin (London, 2011), pp. 72-82. Though dated to ca. 500 вC, the fortified settlement of Zilum near Lake Chad in North-East Nigeria forms an example of the possible southern markets of the trans-Saharan trade a few centuries later. Cf. Carlos Magnavita et al., "Zilum: a MidFirst Millennium BC Fortified Settlement near Lake Chad" Journal of African Archaeology 4 (2006), pp. 153-170. 


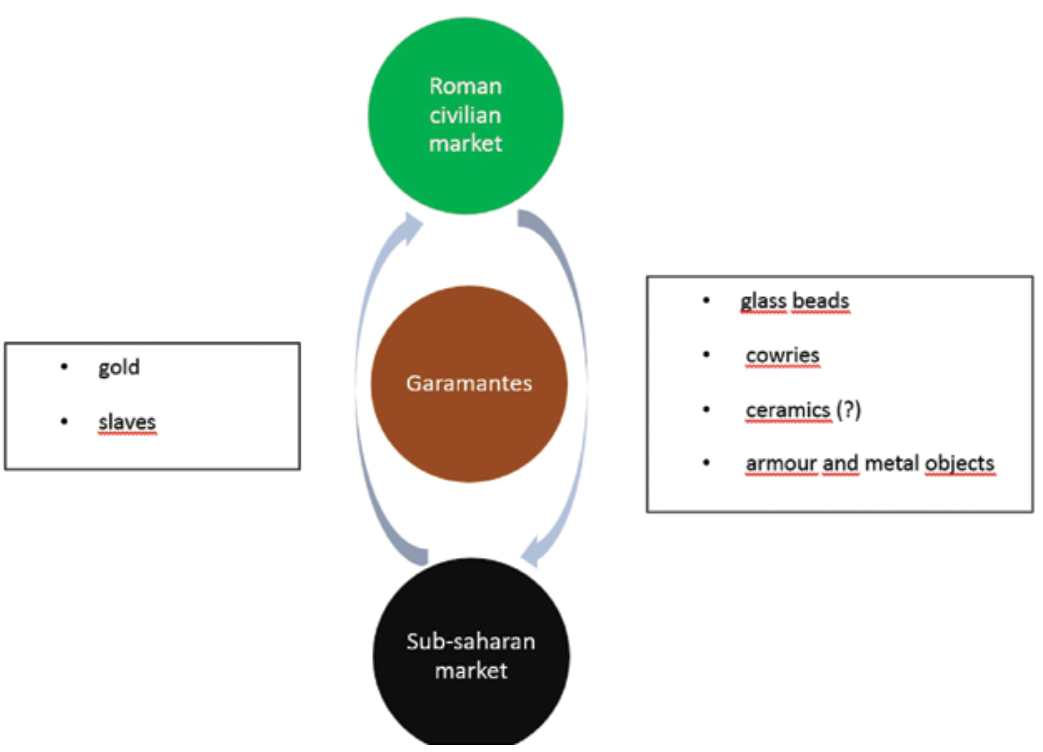

FIGURE 6.4 Mediatory trade between North Africa and Sahel.

for Herodotos already mentions Garamantian slave raids in the land of the Troglodytes. ${ }^{70}$ Rock drawings in the same territory seem to confirm this claim, as they clearly depict slave hunts by ancestors of the Garamantes. ${ }^{71}$ Part of the captured slaves never left Garamantian territory and were used for dangerous tasks, such as the construction of underground foggaras, but others were re-exported to Roman markets. ${ }^{72}$ Swanson's hypothesis that "the Roman empire apparently had no need for slaves from the western Sudan" because

70 Her. Hist. 4, 183, 4.

71 See for instance the scene of a pursuit carved on rocks at Oued Djerat, Henri Lhote, "Les chars rupestres du Sahara et leurs rapports avec le peuplement dans les temps protohistoriques," in Les chars préhistoriques du Sahara. Archéologie et techniques d'attelage. Actes du colloque à Sénanque, 1981, eds. Gabriel Camps, Marceau Gast (Aix-en-Provence, 1982), p. 24; Henri Lhote, Les chars rupestres sahariens des Syrtes au Niger, par le pays des Garamantes et des Atlantes (Toulouse, 1982), p. 108. The forticifation of ancient sub-Saharan settlements may be linked with these pre- and proto-historic raids. Magnavita et al., "Zilum: a Mid-First Millennium BC Fortified Settlement Near Lake Chad," pp. 153-170.

72 Mattingly, "The Archaeology of Fazzān. Vol. I. Synthesis," pp. 276 and 36o. David J. Mattingly, “Nouveaux aperçus sur les Garamantes: un État saharien?," Antiquités africaines 37 (2001), p. 57. The import of black slaves may be suggested by the epigram on the black slave called "faex Garamantum" at Hadrumetum: Franz Bücheler and Alexander Riese, eds. Anthologia Latina sive poesis Latinae supplementum (1894-1897), nr. 183. According to 
"they were readily available in large quantities throughout the empire" can hardly convince. ${ }^{73}$ Apart from the constant need for slave labor and the particular skills sub-Saharan slaves may have possessed (labor in extreme weather conditions), their distant origin and physique created additional value on the slave market, which encouraged masters to pay higher prices and treat their slaves as status objects. ${ }^{74}$

A first candidate for regular imports to sub-Saharan settlements were textiles. Even though funerary contexts in Kissi contained remains of textiles possibly as early as the 1st century $\mathrm{BC}$, equipment to manufacture these textiles have not yet been discovered during the excavations. ${ }^{75}$ One could argue that these woolen textiles may have been produced by hand, yet the rarity of wool producing animals such as camels, dromedaries and sheep in the region before the Arabic period must point to the imported nature of the goods or the raw material. ${ }^{76}$ Particularly interesting in Kissi are the huge quantities of beads, made of glass, stone, metal, bone and shells. ${ }^{77}$ Most siliceous stone beads and metal beads can be assigned to local production areas in Mali and the Niger valley region, but others had been manufactured in more distant regions. Glass was probably produced among the Garamantes, either by recycling imported vessels or by using local sources of natron in their territory. Chemical analysis of the glass beads suggests the raw material, and maybe the finished product as well, had been imported from the Near or Middle East, although Diodorus Siculus mentioned the presence of natron in the inlands beyond Cyrene. ${ }^{78}$

Law, the epigram "equally indicates that this was unusual". Law, "The Garamantes and Trans-Saharan Enterprise in Classical Times," p. 196.

73 Swanson, "The Myth of Trans-Saharan Trade during the Roman Era," p. 596.

74 Walter Scheidel, "Human Mobility in Roman Italy, II: The Slave Population," Journal of Roman Studies 95 (2005), p. 67.

75 Sonja Magnavita, "The Oldest Textiles from Sub-Saharan West Africa: Woolen Facts from Kissi, Burkina Faso," Journal of African Archaeology 6 (2008), p. 244.

${ }_{7} 6$ Sonja Magnavita, "Sahelian Crossroads: Some Aspects on the Iron Age Sites of Kissi, Burkina Faso," in Crossroads: Cultural and technological developments in first millennium $B C / A D$ West Africa, eds. Sonja Magnavita et al. (Frankfurt-am-Main, 2009), pp. 88-91; Magnavita, "The Oldest Textiles from Sub-Saharan West Africa: Woolen Facts from Kissi, Burkina Faso," pp. 246 and 250.

77 Magnavita, "Sahelian Crossroads: Some Aspects on the Iron Age Sites of Kissi, Burkina Faso," pp. 85-86 and 9o-91. Sonja Magnavita, "The Beads of Kissi, Burkina Faso," Journal of African Archaeology 1 (2003), pp. 127-138.

78 Diod. Sic. 3, 50, 1. For glass production among the Garamantes, cf. Mattingly, "The Archaeology of Fazzān. Vol. I. Synthesis," p. 121 (Jarma area), p. 125 (al-Hitaya oasis). Mattingly, "The Archaeology of Fazzān. Vol. III. Excavations carried out by C.M. Daniels," p. 197 (Saniat Jibril), also pp. 413-458. For the availability of natron in their territory: 
Some of the bead sizes, colors and shapes even resemble comparable production in India and Sri Lanka. ${ }^{79}$ The existence of this trans-continental trade route is also confirmed by the discovery of cowries or snail shells originating from somewhere between the Red Sea to the South-Pacific in two graves, which must have reached Kissi together with the beads. ${ }^{80}$ Carnelian beads too must certainly have been imported. The excavators' report pretty vaguely places the origin in an area 'beyond the desert'. ${ }^{\prime}$ Yet, this semi-precious stone was a renowned Garamantian export product and hence an indicator of trans-Saharan exchange. ${ }^{82}$ The standardized nature of these objects can even suggest mass-production by skilled artisans and a large-scale carnelian bead industry in the Garamantian territory. ${ }^{83}$ Part of this local African bead production eventually reached the Roman market as well, so the Garamantes may also have extended their mediatory role in the bead trade to the northern

Mattingly, "The Archaeology of Fazzān. Vol. I. Synthesis," pp. 359-360. Transcontinental imports at Kissi, cf. Peter Robertshaw et al., "Glass Beads from Kissi (Burkina Faso): Chemical Analysis and Archaeological Interpretation," in Crossroads: Cultural and technological developments in first millennium BC/AD West Africa, eds. Sonja Magnavita et al. (Frankfurt-am-Main, 2009) pp. 105-118. The earliest glass beads have been found in graves dated to the 1st-3rd century AD. Large quantities occur in graves dated before the 8 th century AD. Cf. Magnavita, "The Beads of Kissi, Burkina Faso," p. 134. Glass beads were regular grave gifts among the Garamantes as well. Cf. Mattingly et al., "Desert migrations: people, environment and culture in the Libyan Sahara," p. 144.

79 Magnavita, "Sahelian Crossroads: Some Aspects on the Iron Age Sites of Kissi, Burkina Faso," pp. 92-94. Magnavita, "The Beads of Kissi, Burkina Faso," p. 133.

80 Magnavita, "Sahelian Crossroads: Some Aspects on the Iron Age Sites of Kissi, Burkina Faso," p. 94. These finds refute previous claims that cowrie-shells of this type did not reach West Africa in the first millennium A.D. Sutton, "West African metals and the ancient Mediterranean," p. 184.

81 Magnavita, "Sahelian Crossroads: Some Aspects on the Iron Age Sites of Kissi, Burkina Faso," p. 92. Magnavita, "The Beads of Kissi, Burkina Faso", p. 130.

82 Plin. N.H. 37, 92 and 37, 104; Strabo 17, 3, 11 and 19; Plin. N.H. 5, 37.

83 Fragments of carnelian (possibly the 'Garamantian carbuncles' or 'Carthaginian stones', a name identifying the primary trade route) and other semi-precious stones as well as tools to shape and polish beads regularly occur in Garamantian territory. See Mattingly, "The Archaeology of Fazzān. Vol. I. Synthesis", pp. 118-120 (Jarma area), pp. 125-126 (al-Hitaya oasis), pp. 356-358 (overview). Mattingly, "The Archaeology of Fazzān. Vol. III. Excavations carried out by C.M. Daniels," pp. 189-194 (Saniat Jibril), beads pp. 458-470 and tools (bead grinders) pp. 470-474. Similar evidence is available for the Watwat cemeteries and Ghirza: Mattingly et al., "Desert migrations: people, environment and culture in the Libyan Sahara," p. 144. and Brogan and Smith, "Ghirza. A Libyan settlement in the Roman period," p. 243. 
African regions. ${ }^{84}$ Bead analysis thus reveals that considerable amounts must have been brought to Kissi from the Garamantian territory and, via Egypt, from the Near East. It seems very likely that commerce along both trade routes was being organized by Garamantian trans-Saharan entrepreneurs, who specialized in exporting own produce and redistributing imported merchandise to western Africa. ${ }^{85}$

Long-distance trade is also suggested by the metallurgical analysis of several metal objects discovered in grave contexts in Kissi. A pair of anklets, dated to the $5^{\text {th }}-7^{\text {th }}$ centuries, was made of brass, an alloy of copper and zinc. As this production technique has not been attested in western Africa before the 2nd millennium $\mathrm{AD}$, the objects or at least the metal must have been produced elsewhere. ${ }^{86}$ Isotopic ratios are not conclusive to determine the exact origin of the ore, but certainly exclude African sources. ${ }^{87}$ Moreover, the import of brass objects, ingots and/or rods clearly predates the $5^{\text {th }}$ century, for older graves belonging to a time-span between the ist c. $\mathrm{BC}$ and the 4 th $\mathrm{c}$. AD already yielded a brass anklet and bracelet. ${ }^{88}$ Chemical analysis of these two objects suggests the ores originated from Sardinia or southern France. ${ }^{89}$ Early imports of merchandise produced in distant regions are also indicated by fragments

84 The gems possibly originate from the Tibesti area. Plin. N.H. 5, 34.

85 Contra John E.G. Sutton, "Igbo-Ukwu and the Nile," African Archaeological Review 18, no. 1 (2001), pp. 49-62 (esp. p. 52). Sutton argues in favor of routes of commerce between the Nigerian rainforest and Egypt via the Chad Basin.

86 Similarly, Sutton found a brass bracelet in the region of Agades dating to ca. 500 BC and likewise stressed its Mediterranean provenance. Sutton, "West African metals and the ancient Mediterranean," p. 185. It is interesting to note that a North African source of calamine, which is needed to produce brass, has been identified in the Segermes area. Cf. Peter Ørsted, "Part III: Production and Population," in Africa Proconsularis. Regional Studies in the Segermes Valley of Northern Tunisia, eds. Peter Ørsted et al. (Gylling, 200o), pp. $160-161$.

87 Thomas R. Fenn et al., "Contacts Between West Africa and Roman North Africa: Archaeometallurgical Results from Kissi, Northeastern Burkina Faso," in Crossroads: Cultural and technological developments in first millennium BC/AD West Africa, eds. Sonja Magnavita et al. (Frankfurt-am-Main, 2009), p. 128. Copper was nevertheless produced in some regions in North Africa, such as Numidia. Cf. Strabo 17, 3, 11, who somewhat counters the apparent absence of North African copper mentioned by Lucan, Phars. 9, 424-425. Possibly, production levels were fairly low. Swanson, "The myth of trans-Saharan trade during the Roman era," p. 589 .

88 Magnavita, "Sahelian Crossroads: Some Aspects on the Iron Age Sites of Kissi, Burkina Faso," p. 91.

89 Fenn et al., "Contacts Between West Africa and Roman North Africa: Archaeometallurgical Results from Kissi, Northeastern Burkina Faso," p. 127. 
of armor and weaponry. Several small cuprous rings, probably part of a chainmail, closely resemble comparable 3rd-century Mediterranean armor. Chemical analysis confirmed their foreign origin, for the metal alloy of the rings had been produced in the western Mediterranean. Isotopic analysis shows a strong correspondence with Spanish ores, although an origin from Sardinia and even Britain cannot be ruled out. ${ }^{90}$ Additionally two iron swords were found in $5^{\text {th }}-7$ th century graves, which, although the exact location of production is unknown, were either imported or produced locally with previously imported swords as prototypes. At any rate, the chainmail and swords can easily be identified as foreign decorative or status objects, demonstrating the prestige and wealth of their possessor. ${ }^{91}$ The fact that trans-Saharan merchants were well-aware of the potential value of these exotic goods may stress the regularity of commercial contacts. In conclusion, the combination of archaeological and chemical analysis clearly reveals the import of non-African ores, bars, rods and/or metal objects to Kissi. It is possible merchants were supplying a combination of finished objects and raw material, which at various nodes of the trade network and even at the end of the trans-Saharan route could be mixed with local ores and processed into whatever objects were in demand. This production process of mixing and assembling ores can explain why the chemical analysis of some simple every-day objects such as bracelets and anklets was sometimes unable to pinpoint an exact origin. ${ }^{92} \mathrm{On}$ the other hand, objects such as the chainmail, whose exotic origin mainly reflected status and affluence, were more likely imported as finished goods, produced in the Mediterranean area and with a clear isotopic ratio of a particular mining area. Comparable isotopic analysis of other African metal objects show many correspondences between the Kissi artifacts and the objects found in Carthage and Tunisia from the Punic and Roman period. ${ }^{93}$ They apparently must have shared a common 'trade pool' of ores, mainly originating from the western Mediterranean. This merchandise was thus probably following caravan routes south from Carthage to the Hoggar and the Agadez region of Niger, where goods were being reconfigured for east-west trade. From the Niger valley, goods eventually reached the Kissi region. Given that the Garamantes had clear commercial contacts with Carthage, we may again hypothesize that the

\footnotetext{
$90 \quad$ Ibid., pp. 126-127.

91 Magnavita, "Sahelian Crossroads: Some Aspects on the Iron Age Sites of Kissi, Burkina Faso," pp. 91-92 and 96.

92 Fenn et al., "Contacts Between West Africa and Roman North Africa: Archaeometallurgical Results from Kissi, Northeastern Burkina Faso," pp. 130 and 136-137.

93 Ibid., pp. 130-133.
} 
trans-Saharan trading networks linking the north-African coastal regions with south-Saharan regions were dominated by Garamantian entrepreneurs.

Finally, as the Garamantes were practically living in the center of a broad range of commercial networks, they were at least able to re-export part of the Mediterranean goods acquired in exchange for the merchandise transported into Roman territory. The Mediterranean ceramics found in Garamantian graves offer a good example for the kind of alien objects crossing the border, probably in the first place as luxury items. ${ }^{94}$ During the late 1 st and early 2nd century $\mathrm{AD}$, the period of the highest concentration of imported grave goods, Mediterranean vessels appear to have reached the Garamantian territory in small batches, pointing to a rather early take-off in trade with the cities along the Mediterranean coast. ${ }^{95}$ Italian and Gallic sigillata dominate the collections during this period. ${ }^{96}$ Interestingly, African pottery with "tribal" or "Saharan" themes appear in North Africa in the later Roman period, suggesting a mutual exchange of production techniques or at least familiarity with decorative motives favored in more southern regions. ${ }^{97}$ Amphorae finds include shreds of late Greco-Italic and Dr. 1 wine amphorae, Tripolitanian wine and oil

94 General overview in Mattingly, "The Archaeology of Fazzān. Vol. I. Synthesis," pp. 227-232. For a more southern settlement, see Liverani, "Looking for the Southern Frontier of the Garamantes." For the import of high-quality glass vessels and faience, see Mattingly, "The Archaeology of Fazzān. Vol. II. Site Gazetteer, Pottery and Other Survey Finds," p. 485.

95 Mattingly, "The Archaeology of Fazzān. Vol. III. Excavations carried out by C.M. Daniels," pp. 526-529.

96 Italian and Gallic pottery: Mattingly, "The Archaeology of Fazzān. Vol. II. Site Gazetteer, Pottery and Other Survey Finds," pp. 331-332. and Mattingly, "The Archaeology of Fazzān. Vol. III. Excavations carried out by C.M. Daniels," p. 165 (Saniat Jibril). A detailed analysis of the pottery in the region is offered by Mattingly, "The Archaeology of Fazzān. Vol. II. Site Gazetteer, Pottery and Other Survey Finds," pp. 305-425. See also Mattingly, "The Archaeology of Fazzān. Vol. III. Excavations carried out by C.M. Daniels," pp. 222-341 for Saniat bin Huwaydi graves. This trade pattern with the Mediterranean area appears to have been disrupted during the third century, when the port cities faced economic decline, a rapidly decreasing demand for slaves and change in levels of connectivity. At the same time, imports of Mediterranean merchandise to the Garamantian territory were seriously reduced from the late third century onwards. This period coincides with the appearance of qsur or castles in Wadi al-Ajal, pointing to a less secure society and trading world. For this chronological evolution, see Mattingly, "The Archaeology of Fazzān. Vol. I. Synthesis," pp. 277 and 349 .

97 Increased contact in the pottery industry may lay at the origin of the depiction of tribal and Saharan themes on African sigillata, cf. Sergio Fontana, "Tradizione artigianale e raffigurazione di tipi etnici nei balsamari configurati di produzione africana (III-IV sec. d. C.)," Quaderni di archeologia della Libia 17 (1995), p. gof. 
amphorae and Late Roman wine amphorae. ${ }^{98}$ These may have been the kind of wine amphorae mentioned in the Zaraï and Lambaesis tariffs. It is interesting to note that several items show the same potter's stamp and graffiti, suggesting they at one time had belonged to the same collection of objects. The arrival of Mediterranean ceramics in the African port cities is probably to be connected with the Roman food supply (annona), for the grain ships returning from Ostia often filled the hold with low-value and easily stackable objects to quickly return to Africa and start another voyage. ${ }^{99}$ The grave goods indeed show a remarkable preference for large open forms of both glass vessels and ceramics, which are very easy to store in the hold. ${ }^{100}$ The presence of Roman ceramics and amphorae among the grave gifts shows these objects were destined for local consumption by the Garamantes themselves, but the status of rather rare, exotic luxury items made them perfectly suitable for re-export to more remote tribes, who only interacted with the Mediterranean area via commercial contacts with Garamantes and other nomads. Moreover, an opposite movement of pottery of sub-Saharan origin to Garamantian territory can be traced, suggesting pottery and ceramics did indeed qualify as commercial goods. ${ }^{101}$

\section{Conclusion}

The analysis of cross-border commercial contacts between nomadic and sedentary societies in Roman North Africa clearly suggests that previous studies have underestimated both the scope and scale of exchange controlled by pastoral tribes such as the Garamantes. ${ }^{102}$ Ongoing archeological surveys now

98 Mattingly, "The Archaeology of Fazzān. Vol. II. Site Gazetteer, Pottery and Other Survey Finds," pp. 310-311 and 336-363.; Mattingly, "The Archaeology of Fazzān. Vol. III. Excavations carried out by C.M. Daniels," pp. 167-168 (Saniat Jibril).

99 Christian Rico, "La diffusion par mer des matériaux de construction en terre cuite : un aspect mal connu du commerce antique en Méditerranée occidentale," Mélanges de l'École française de Rome. Antiquité 107 (1995), pp. 767-80o.

100 Mattingly, "The Archaeology of Fazzān. Vol. I. Synthesis," p. 229.

101 Liverani, "Looking for the Southern Frontier of the Garamantes," p. 37. Maria C. Gatto, "The Local Pottery," in Aghram Nadharif. The Barkat Oasis (Sha'Abiya of Ghat, Libyan Sahara) in Garamantian Times, ed. Mario Liverani (Firenze, 2005), pp. 239-240.

102 The monopoly of the Saharan peoples in this trade system has been underscored by biodistance studies based on cranial traits of human remains. A recent survey concludes that there was no biological interaction between the Garamantes and outsiders (originating from the Mediterranean world, Egypt or Meroe). Nikita, Mattingly, and Mirazon Lahr, 
allow a reassessment of the traditional triangular trade patterns and begin to stress, first, the economic value of merchandise produced by the pastoralists themselves, in particular for the military markets along the frontier, and second, the wide range of goods transported by the nomads in a mediatory trade model to the northern and southern markets alike. The nomadic tribes must therefore be considered valuable economic partners promoting interaction and exchange between otherwise isolated regions and deliberately capturing the benefits long-distance trade had to offer, rather than small-scale entrepreneurs only occasionally engaging in commercial exchange.

"Sahara: Barrier of Corridor? Nonmetric Cranial Traits and Biological Affinities of North African Late Holocene Populations." Unfortunately, the study did not include individuals from sub-Saharan regions. 


\title{
Transfer römischer Technik jenseits der Grenzen: Aneignung und Export
}

\author{
Günther Schörner
}

$1 \quad$ Einführung

Wird das Thema 'Rom jenseits der Grenze' aus archäologischer Perspektive behandelt, so bedeutet dies normalerweise, sich mit so genannten römischen Importen in das Barbaricum zu befassen, also Objekten, die in Italien oder den Provinzen des Römischen Reiches hergestellt wurden und die aus unterschiedlichen Gründen in Gebiete außerhalb des Imperium gelangten. Geläufige Objekte dieser Art sind hochqualitative Keramik, Gefäße oder andere Gegenstände aus Metall, Glas und Münzen¹. Die wissenschaftliche Beschäftigung beschränkt sich nicht mehr nur auf die corpus-mäßige Erfassung

Der vorliegende Aufsatz stellt die erweiterte deutsche Fassung meines Vortrags dar, der unter dem Titel Technology Transfer beyond the Frontiers: Imperial Politics and Local Accomodation am 15. Juni 2013 in New York gehalten wurde. Mein Dank gilt Olivier Hekster (Nijmegen), Daniëlle Slootjes (Nijmegen) und Michael Peachin (New York) für die Einladung zum Elften Workshop des Internationalen Netzwerks ,Impact of Empire. Für wichtige Auskünfte und Kommentare danke ich R. Breitwieser (Salzburg), W. Eck (Köln), M. Speidel (Zürich), K. Sporn (Salzburg/Athen), R. Talbert (Chapel Hill, North Carolina) und N. Wicker (Oxford, Mississippi) sowie meiner Frau H. Schörner.

1 Grundlegende Werke zum so genannten römischen Import: Hans Jürgen Eggers, Der römische Import im Freien Germanien, (Atlas der Urgeschichte) 1 (Hamburg, 1951); Jürgen Kunow, Der römische Import in der Germania libera bis zu den Markomannenkriegen. Studien zu Bronze- und Glasgefäßen, (Göttinger Schriften zur Vor- und Frühgeschichte) 21 (Neumünster, 1983); Ulla Lund Hansen, Römischer Import im Norden, (Nordiske Fortidsminder ser. B) 10 (Kopenhagen, 1987); Lotte Hedeager, „Empire, Frontier and the Barbarian Hinterland: Rome and Northern Europe from $\mathrm{AD} 1-400, "$ in Centre and Periphery in the Ancient World, hrsgg. Michael J. Rowlands, Mogens Larsen Kristian Kristiansen (Cambridge, 1987) S. 125-140; Reinhard Stupperich, „Bemerkungen zum römischen Import im sogenannten Freien Germanien," in Aspekte römisch-germanischer Beziehungen in der frühen Kaiserzeit, hrsg. Georgia Franzius, (Bramsche, 1995) S. 45-98; Reallexikon der Germanischen Altertumskunde Band 25 hrsgg. Heinrich Beck, Dieter Geuenich, Heiko Steuer (Berlin, 2003) S.v. „Römischer Import § 1: Historisches,“ S. 138-143 (Reinhard Wolters); „Römischer Import $\S 2$ : Archäologisches," S. 143-158 (Michael Erdrich - Hans-Ulrich Voß). 
dieser Importe in das Gebiet östlich des Rheins oder nördlich der Donau², sondern bezieht auch andere Regionen und weitergehende Fragestellungen mit ein ${ }^{3}$.

Versteht man den Begriff ,Artefakt ' jedoch in einem weiteren Sinn, so muss er sich nicht auf isolierte Objekte beschränken, sondern kann auch Techniken und die mit ihnen verbundenen Gegenstände - seien es nun einfache Geräte oder komplexere Einrichtungen - umfassen ${ }^{4}$. Die Erweiterung des ArtefaktBegriffs in diese Richtung erlaubt es, Kulturkontakte zwischen Imperium Romanum und indigenen Gesellschaften jenseits der Grenzen auf einer anderen materiellen Basis und mit anderen Fragestellungen zu untersuchen.

Im Folgenden sollen zunächst einige Beispiele für Transfer von Technologie ganz unterschiedlicher Art, mit unterschiedlichem Erfolg und an unterschiedlichen Orten vorgestellt werden ${ }^{5}$; in einem zweiten Teil werden übergeordnete Fragen angesprochen, wobei Anregungen aus dem Bereich der sTs (Science and Technology Studies) aufgegriffen werden ${ }^{6}$.

2 Maßgeblich die Publikationsreihe der Römisch-Germanischen Kommission des Deutschen Archäologischen Instituts, beispielsweise Rudolf Laser, Hans-Ulrich Voß, Corpus der römischen Funde im europäischen Barbaricum D 1: Bundesländer Brandenburg und Berlin (Bonn, 1994); Stefan Berke, Corpus der römischen Funde im europäischen Barbaricum D 7: Land Nordrhein-Westfalen, Landesteile Westfalen und Lippe (Bonn, 2009).

3 Vgl. Reinhard Wolters, „Der Waren- und Dienstleistungsaustausch zwischen dem Römischen Reich und dem Freien Germanien in der Zeit des Prinzipats - eine Bestandaufnahme Teil 1," Münstersche Beiträge zur Antiken Handelsgeschichte 9/1 (1990), 14-44; ders., „Der Waren- und Dienstleistungsaustausch zwischen dem Römischen Reich und dem Freien Germanien in der Zeit des Prinzipats - eine Bestandaufnahme Teil 2," Münstersche Beiträge zur Antiken Handelsgeschichte 10/1 (1991), 78-131. Entscheidend jetzt die Aufsätze in Peter S. Wells, Hrsg., Rome beyond its Frontiers: Imports, Attitudes, and Practices, Supplement Journal of Roman Archaeology 94 (Portsmouth, Rhode Island, 2013) (im Folgenden zitiert als Wells, Rome beyond its Frontiers).

4 Vgl. für diesen Ansatz: Ron Eglash, "Technology as Material Culture," in Handbook of Material Culture, hrgg. Christopher Tilley u.a., (London - Thousand Oaks - New Delhi, 2006) 329-340.

5 Der Begriff, Technologie‘ wird hier in Analogie zum Englischen auch im Deutschen synonym $\mathrm{zu}$,Technik' verwendet und nicht im Sinne einer ,Herstellungs- und Verarbeitungskunde‘.

6 Einführende Literatur:Wenda Bauchspies, Jennifer Croissant, Sal Restivo, Science, Technology, and Society: A Sociological Approach (Malden, Massachusetts - Oxford, 2005); Kevin Greene, "Historiography and Theoretical Approaches," in Handbook of Material Culture, hrsg. John P. Oleson (Oxford, 2008) S. 62-90; Stefan Beck, Jörg Niewöhner, Estrid Sörensen, Science and Technology Studies: Eine sozialanthropologische Einführung (Bielefeld, 2012). Besonders wichtig für die Archäologie ist innerhalb sTs meines Erachtens die Richtung, die auf die soziale Bedingtheit von Techniken hinweist, nämlich Social Construction of Technology (scot) und daraus entwickelte neuere Ansätze; hierfür grundlegend: Wiebe Bijker, Thomas Hughes, 


\section{$2 \quad$ Fallstudien}

\subsection{Pannonisches Limesvorland}

In Cifér-Pác in der heutigen Slowakei wurden in der zweiten Hälfte des 20 Jahrhunderts in einer größeren germanisch geprägten Siedlung eine Gruppe von Häusern freigelegt, deren wichtigstes eine rechteckige Struktur mit Mauern aus Steinen in Mörtelbindung ist, die auf römische Mauertechnik verweist ${ }^{7}$. Im Gebäude wurden zudem ein Ypsilon-förmiger Heizkanal und Fragmente von Tubuli-Ziegeln aufgedeckt, die eine Hypokaustenheizung belegen ${ }^{8}$. Der Kontrast zwischen diesem repräsentativen und gut ausgestatteten Steingebäude und den einfachen Flechtwerkhütten im unmittelbaren Umfeld muss beträchtlich gewesen sein. Einige der Grubenhäuser in germanischer Tradition zeigen freilich eine Kombination unterschiedlicher Baumaterialien,

Trevor Pinch, Hrsgg., The Social Construction of Technological Systems: New Directions in the Sociology and History of Technology (Cambridge, Massachusetts - London, 1987); Pierre Lemonnier, Hrsg., Technological Choices: Transformation in Material Cultures Since the Neolithic: Transformations in Material Cultures Since the Neolithic (London - New York, 1993); Robin Williams - David Edge, "The Social Shaping of Technology," Research Policy 25 (1996), 865-899; Donald MacKenzie, Judy Wajcman, Hrsgg., The Social Shaping of Technology: How the Refrigerator Got Its Hum (Milton Keynes, 1999); Hans K. Klein, Daniel Lee Kleinman, "The Social Construction of Technology: Structural Considerations," Science, Technology \& Human Values 27 (2002), 28-52; Wiebe E. Bijker, "Social Construction of Technology," in: A Companion to the Philosophy of Technology, hrsgg. Jan Kyrre Berg Olsen u.a. (Malden, Massachusetts Oxford, 2009) S. 88-94; Estrid Sörensen, „Die soziale Konstruktion von Technologie (sсOT),“ in Science and Technology Studies: Eine sozialanthropologische Einführung (Bielefeld, 2012) S. 123-144.

7 Zum Fundplatz: Titus Kolník, "Neskororímska vojenská stanica v Páci," Archeologické rozhledy 24 (1972), 59-72. 111-116; ders., "Römische Stationen im slowakischen Abschnitt des nordpannonischen Limesvorlandes," Archeologické rozhledy 38 (1986), 415-420; Lynn F. Pitts, "Roman Style Buildings in Barbaricum (Moravia and sw Slovakia)," Oxford Journal of Archaeology 6 (1987), 234-236; Titus Kolník, "Nordpannonische Limesland-Forschung 1984-1996," in Proceedings of the XVII. International Congress of Roman Frontier Studies, hrsg. Nicolae Gudea (Zalău, 1999) S. 131-137; Titus Kolnik, Jan Rajtár, „Neue Angaben zur Ausdehnung und Funktion der Römisch-germanischen Anlage Cífer-Pác,“ Študijné zvesti archeologického ústavu sav 36 (2004), S. 203-210; Vladimimír Varsik, Titus Kolník, „Cifér-Pác Neue Erkenntnisse zur spätantiken quadischen Elitenresidenz," in Macht des Goldes, Gold der Macht : Herrschafts- und Jenseitsrepräsentation zwischen Antike und Frühmittelalter im mittleren Donauraum Akten des 23. Internationalen Symposiums der Grundprobleme der Frühgeschichtlichen Entwicklung im Mittleren Donauraum, Tengelic, 16. - 19.11.2011, hrsg. Matthias Hardt (Weinstadt, 2013) S. 71-89 (mit der älteren Lit.).

8 Kolnik, Rajtár, „Neue Angaben,“ S. 203. 
da sie mit tegulae gedeckt waren, so dass römische Bautechnik nicht auf das bereits erwähnte Gebäude beschränkt bleibt.

Die Siedlung kann durch Keramik und Münzen in die Zeit vom frühen 2. bis zum späteren 4. Jahrhundert n. Chr. datiert werden, wobei die meisten der früheren Funde aus den mit herkömmlichen Materialien konstruierten Hütten stammen, während für die aufwändigen Strukturen eine Errichtung in der Spätzeit der Siedlung wahrscheinlich ist ${ }^{9}$. Daraus lässt sich schließen, dass in einer seit dem 2. Jahrhundert n. Chr. existierenden germanischen Siedlung in Cífer-Pác in der 1. Hälfte des 4. Jahrhunderts eine massive Umgestaltung erfolgte, indem eine große Anlage in römischer Steinbauweise und mit einer Heizung römischen Typs errichtet wurde und für einfachere Häuser partiell römische Bautechnik angewandt wurde, die mit Dachziegeln anstelle Stroh gedeckt waren. Die Errichtung dieser Gebäude und damit die Implementierung römischer Bautechnik fallen in eine Zeit, als römische Militärkampagnen jenseits der Donau durchgeführt wurden, wie Ammianus Marcellinus schreibt ${ }^{10}$. Von besonderer Wichtigkeit für die Bewertung des Technologietransfers ist die funktionale Charakterisierung Cifér-Pács: Die Tradition als indigener Siedlungsplatz und das Fehlen spezifisch fortifikatorischer Bauten sprechen gegen eine Interpretation als römischer Militärposten, sondern eher für einen besonders herausgehobenen Wohnsitz eines lokalen Potentaten, der mit Hilfe römischer Truppen errichtet wurde, wobei auch für einfachere Architekturen partiell römische Baumaterialien adaptiert wurden ${ }^{11}$.

Eine ähnliche Konstellation können wir an einem anderen Ort im Vorfeld des pannonischen Limes greifen, nämlich Bratislava-Dúbravka in der Nähe des Zusammenflusses von Donau und March. Wie Cifér-Pác bestand der Siedlungsplatz in einer ersten Phase seit der 2. Hälfte des 1. Jahrhunderts n. Chr. aus einer kleinen Ansammlung von Grubenhäusern mit Wänden aus Flechtwerk und strohgedeckten Dächern ${ }^{12}$. Dieser relativ einfache, indigene

9 Ibid.

$10 \quad$ Ammianus Marcellinus XXIX 6.

11 Symptomatisch die Neubewertung des Fundplatzes in den Schriften von Titus Kolník. Kolník, „Stanica“: römische Militärstation; Kolník, „Römische Stationen“: polyfunktionelle Anlage; Kolník, „Limesland-Forschung“: germanische Residenz.

12 Zum Fundplatz: Kolník, „Römische Stationen,“ 431; Janka Hečková, „Römischer Baukomplex in Stupava“, Archeologické rozhledy 38 (1986), 392; Pitts, „Roman Style Buildings“, 227-229; Kristian Elschek, „Die germanische Besiedlung von BratislavaDúbravka während der älteren römischen Kaiserzeit," in Kelten, Germanen, Römer im Mitteldonaugebiet, hrsgg. Jaroslav Tejral u. a. (Brünn - Nitra, 1995) S. 39-52; Kristian Elschek, „Römisch-germanische villae rusticae im Limesvorfeld von Carnuntum? Ergebnisse systematischer Grabung und Prospektion," in: Roman Frontier Studies 1995 
Charakter wurde während der nächsten Phase, die aufgrund von Keramikund Münzfunden in die 2. Hälfte des 3. Jahrhunderts datiert werden kann, beträchtlichen Veränderungen unterworfen, unter denen die Errichtung eines $13 \times 11 \mathrm{~m}$ großen Gebäudes in Steinbautechnik die wichtigste war ${ }^{13}$. Die Ziegel zur Eindeckung dieses im Siedlungskontext sehr eindrucksvollen Gebäudes wurden aus der römischen Provinz Pannonien importiert, wie Ziegelstempel belegen ${ }^{14}$. Besonders auffällig ist das Gebäude aufgrund seines für die Region außergewöhnlichen Grundrisses mit drei Apsiden, für den sich aber in den römischen Nordprovinzen enge Parallelen finden lassen, da bei Thermenanlagen von Villen Frigidarium, Tepidarium und Caldarium häufig absidal abgeschlossen sind ${ }^{15}$. Trotz dieser formalen Übereinstimmung zwischen dem Gebäude in Bratislava-Dúbravka und den provinzialen Badeanlagen gibt es einen fundamentalen Unterschied: Es existiert nicht der geringste Hinweis darauf, dass das Gebäude im Limesvorland beheizt war, wie es für eine Nutzung als Therme unbedingt $\mathrm{zu}$ fordern ist ${ }^{16}$. Es kann nur spekuliert werden, weshalb keine Heizung eingebaut wurde, ob beispielsweise der ursprüngliche Bauplan aufgegeben wurde. Zweifelsfrei steht jedoch fest, dass es anders genutzt werden musste als seine formalen Vorbilder. Obwohl das Gebäude wie ein römisches Bad ausgesehen hat, wie sie in den Nordprovinzen von zahlreichen Exemplaren bekannt sind, konnte es nicht dieselben Funktionen eines temperaturmäßig ausdifferenzierten Bades erfüllen, so dass das Gebäude in Bratislava-Dúbravka zugespitzt als Thermenattrappe bezeichnet werden könnte.

(Oxford, 1997) S. 225-232; Kristian Elschek, „Ausgewählte römische Fibeltypen vom slowakischen Marchgebiet im Limesvorland von Carnuntum und ein neues Fürstengrab der "Lübsow-Gruppe" von Zohor," in Kelten, Germanen, Römer im Mitteldonaugebiet, hrsgg. Gerald Grabherr, Barbara Kainrath, Thomas Schierl (Innsbruck 2013) S. 195 (mit der älteren Lit.).

13 Zur Datierung: Elschek, „Römisch-germanische villae rusticae,“ 225.

14 Elschek, „Römisch-germanische villae rusticae,“ 228. So ist Septimius Vitalis auch aus Vindobona bekannt: Friedrich Kenner, Bericht ueber roemische Funde in Wien in den Jahren 1896-1900 (Wien, 1900) S. 7 Abb. 4; 24.

15 Zu Thermen in den benachbarten Provinzen Noricum und Pannonien: Stefan Traxler Raimund Kastler, Hrsgg., Römische Bäder in Raetien, Noricum und Pannonien. Colloquium Lentia 2010. Beiträge zur Tagung im Schlossmuseum Linz 6.-8. Mai 2010 (Studien zur Kulturgeschichte von Oberösterreich) 27 (Linz, 2012).

16 Kristian Elschek, „Rímsko-germánska vidiecka usadlost' s kúpel’om v Bratislave-Dúbravke,“ Pamiatky a múzeá 3 (2000), 27-29; vorsichtiger: Pitts, „Roman Style Buildings“, 228 (ungenutztes praefurnium, Bau evtl. unfertig). 


\subsection{Germania magna}

2.2.1 Keramikherstellung

Ein besonders vielschichtiges Beispiel für Technologietransfer stellt die Töpferwerkstatt im thüringischen Haarhausen dar. In diesem Ort im heutigen Thüringen wurden von Sigrid Dušek in den 1980er Jahren drei Töpferöfen und weitere Anlagen zur Keramikproduktion ausgegraben ${ }^{17}$. Alle Öfen sind frei stehende Anlagen und setzen sich aus einem Feuerungskanal, einem Feuerungsraum und einem Brennraum zusammen, die durch eine Lochtenne voneinander getrennt sind ${ }^{18}$. Die Gestalt der Öfen zeigt einen charakteristischen Grundriss in Form eines Schlüssellochs, da der Feuerungskanal schmaler ist als der Brennraum und dieser durch eine Wand noch partiell zweigeteilt ist. Während diese unteren Partien aus mit Stroh gemagertem Lehm bestehen, wurde die Kuppel des Brennraums aus ineinander gefügte Gefäße, die mit Lehm verstrichen sind, errichtet und abschließend mit Kalkmörtel verputzt. Die durch diese konstruktiven Details charakterisierte Bauweise der Töpferöfen hat keine Parallelen außerhalb des Imperium Romanum, da weder im näheren wesergermanischen und elbgermanischen Bereich noch in den weiter entfernten großen Töpfereizentren in Polen und Mähren vergleichbare Konstruktionen gefunden wurden ${ }^{19}$. Innerhalb des Imperium Romanum gibt

17 Sigrid Dušek, „Die Produktion römischer Drehscheibenkeramik in Thüringen Technologie, ökonomische und gesellschaftliche Konsequenzen," in Römerzeitliche Drehscheibenkeramik im Barbarikum. Symposium Weimar, 21. bis 25. Mai 1984., hrsg. Rudolf Feustel, Weimarer Monografien zur Ur- und Frühgeschichte 11 (Weimar, 1984) S. 6-18; dies., „Produktion und Verbreitung römischer Reibschalen im hermundurischen Thüringen,“ Acta Rei Cretariae Romanae Fautores 29/30 (1991), 137-148; dies., Römische Handwerker im germanischen Thüringen. Ergebnisse der Ausgrabungen in Haarhausen, Kreis Arnstadt. Teil A: Auswertung (Stuttgart, 1992) (im Folgenden zitiert als Dušek, Haarhausen); dies., Römische Handwerker im germanischen Thüringen. Ergebnisse der Ausgrabungen in Haarhausen, Kreis Arnstadt. Teil B: Fundbericht (Stuttgart, 1992); Oliver Stoll, „Der Transfer von Technologie in der römischen Antike: einige zusätzliche Bemerkungen zu einem Buch von Sigrid Dušek," Münstersche Beiträge zur Antiken Handelsgeschichte 12/2 (1993), 93-118; Sigrid Dušek, Ur- und Frühgeschichte Thüringens (Stuttgart, 1999) S. 134137; Bernd Steidl, „Lokale Drehscheibenkeramik römischer Formgebung aus dem germanischen Mainfranken. Zeugnis für die Verschleppung römischer Reichsbewohner nach Germanien?", Bayerische Vorgeschichtsblätter 67 (2002), 87f. und passim (im Folgenden zitiert als Steidl, „Drehscheibenkeramik“).

18 Dušek, Haarhausen, S. 12-17,

19 Dušek, Haarhausen, S. 52-66. Zur eventuellen Tätigkeit provinzialrömischer Töpfer in Südpolen: Pavel Wielkowiejski, "Przemiany gosdpodarczo-spoleczne u ludności południowej Polski w okresie późno-latenskim i rzymskim," Materiaty Starožytne 6 (1960), 119); in der Ostslowakei Pavel Jurečko, „Problematika tzv. siwej keramiky v dobe rimskej 
es jedoch zahlreiche Parallelen für die Haarhausener Öfen. So wurden in NidaHeddernheim in der Provinz Germania superior Anlagen aufgedeckt, die in Gestaltung, Konstruktionstechnik und verwendeten Materialien, insbesondere den Wölbtöpfen, sehr gut vergleichbar sind ${ }^{20}$. Die Ähnlichkeiten sind so stark, dass S. Dušek Haarhausen als einen Filialbetrieb der Heddernheimer Töpfer bezeichnet; diese Fokussierung auf einen spezifischen Herkunftsort wird jedoch in jüngerer Zeit abgelehnt ${ }^{21}$. Eindeutig ist jedoch der weitreichende Transfer römischer Technik für die Konstruktion von Töpferöfen, wobei sich die Implementierung römischen Knowhows nicht auf diesen Bereich beschränkt. Auch die Errichtung eines $12 \times 5 \mathrm{~m}$ großen Gebäudes, das wohl als Trocken- und Arbeitshalle diente, verweist auf die Übernahme provinzialer Bautechnik ${ }^{22}$. Der Ausstoß der Töpferei in Haarhausen wurde aufgrund der Anzahl der Öfen, ihrer Größe und der vermutlichen Anzahl von möglichen Brennvorgängen auf ca. 60.000-70.00o Gefäßen pro Jahr geschätzt, woran 25 bis 30 Töpfer und weitere Arbeitskräfte beteiligt gewesen sein könnten ${ }^{23}$.

Beim Brennen kam ebenfalls römische Technologie zur Anwendung, da ringförmige Abstandhalter und auch Ständer gefunden wurden, die Parallelen in Nida-Heddernheim besitzen ${ }^{24}$. Der Brandvorgang selbst fand in einer sauerstoffarmen, also reduzierenden Atmosphäre statt und unterschied sich dadurch zur gängigen Praxis im Imperium Romanum ${ }^{25}$. Dies bedeutet, dass die Gefäße einen grauen bis schwarzen Scherben bei einer lederfarbigen bis schwarzen Oberfläche aufweisen im Kontrast zu den beige-rötlichen Erzeugnissen der römischen Werkstätten.

In Haarhausen wurde überwiegend Keramik auf der schnell drehenden Töpferscheibe hergestellt, nur ca. ein Viertel der gefundenen Scherben gehört zu frei geformten Gefäßen, die also in der im rhein-wesergermanischen Kreis üblichen Produktionstechnik gefertigt wurden. Die Gefäße entsprechen zum einen bekannten germanischen Typen, ersetzen also ohne Töpferscheibe hergestelltes Geschirr durch qualitativ höherwertige Drehscheibenkeramik, zum anderen folgen sie formal Produkten aus dem Imperium Romanum, so

so zretelom na výsledky výskumu na východnom Slovensku," Historica Carpatica 12 (1981), 169-209.

20 Dušek, Haarhausen, S. 56f.; zu Töpferöfen in Nida-Heddernheim: Susanne Biegert, Römische Töpfereien in der Wetterau (Frankfurt; 1999).

21 Steidl, „Drehscheibenkeramik," S. 107 Anm. 47.

22 Dušek, Haarhausen, S. 17-19.

23 Dušek, Haarhausen, S. 98-101.

24 Dušek, Haarhausen, S. 68f.

25 Signifikant ist die germanische Terra nigra-Keramik: Dušek, Haarhausen, S. 93-98; vgl. jedoch die kritischen Bemerkungen bei Steidl, „Drehscheibenkeramik,“ S. 99f. Anm. 25. 
dass insbesondere Krüge und Reibschalen (mortaria) zum Repertoire der Handwerker in Haarhausen gehören ${ }^{26}$. Für die römischen Gefäßformen lässt sich kein einheitlicher Ursprungsort festmachen, da anscheinend Vorlagen aus verschiedenen Regionen verwendet wurden und Parallelen in Germania inferior, Germania superior, Gallia belgica und Raetia nachzuweisen sind.

Die Produktionsstätte in Haarhausen kann durch Kleinfunde, vor allem Fibeln des Typs Almgren 175, 177 und 181 sowie 14 C-Datierungen in die Jahre zwischen 260 und 290 gesetzt werden ${ }^{27}$. Die Töpferei war also nur in einer Zeit in Betrieb, als der Obergermanisch-rätische Limes bereits gefallen war und als das Imperium Galliarum zumindest zeitweise der bestimmende Faktor in der Region war' ${ }^{28}$.

Keramik aus Haarhausen wurde in mehr als 150 Orten überwiegend in Thüringen gefunden, wurde aber wahrscheinlich bis nach Mainfranken verhandelt ${ }^{29}$. Gefäße der Haarhausener Produktion sind auch in den Fürstengräbern von Hassleben-Leuna bezeugt, die in die Zeit von 260 bis $310 \mathrm{n}$. Chr. datiert werden können, so dass der vor Ort gewonnene Ansatz bestätigt wird ${ }^{30}$.

Zweifellos liegt in Haarhausen eine besonders komplexe Form von Technologietransfer vor, da folgende römische Techniken bezeugt sind:

1. Konstruktion von Töpferöfen

2. Produktion von Drehscheibenkeramik

3. Beschickung der Töpferöfen und auch teilweise der Brennvorgang

Die Töpferwerkstatt in Haarhausen war ein relativ kurzzeitiges Phänomen. Die Produktion fällt in die 2. Hälfte des 3. Jahrhunderts n. Chr., so dass Gefäße in römischer Formtradition nur eine Generation lang bis zu Beginn des 4 . Jahrhunderts hergestellt werden. Die Verwendung der Töpferscheibe setzt sich

26 Dušek, Haarhausen, S. 70-93; vgl. aber auch die Bemerkungen bei Steidl, „Drehscheibenkeramik," S. 103-105.

27 Dušek, Haarhausen, S. 51 f.

28 Zum Imperium Galliarium: John F. Drinkwater, The Gallic Empire. Separatism and Continuity in the North-Western Provinces of the Roman Empire A.D. 260-274, (Historia Einzelschriften) 52 (Stuttgart, 1987); Thomas Fischer, Hrsg., Die Krise des 3.Jahrhunderts $n$. Chr. und das Gallische Sonderreich (Wiesbaden, 2012) (mit der weiteren Lit.).

29 Dušek, Haarhausen, S. 103-115; Beleg in Mainfranken: Steidl, „Drehscheibenkeramik,“ S. 100.105 .

$30 \quad$ z.B.W. Schulz, Das Fürstengrab von Hassleben, (Römisch-Germanische Forschungen) 7 (Berlin - Leipzig, 1933) S. 6. 21. 51; vgl. auch Steidl, „Drehscheibenkeramik,“ S. 110 mit Anm. 57 . 
jedoch über das 4. Jahrhundert bis in das 5. Jahrhundert hinein fort, wobei dann aber nur noch germanische Gefäßtypen wie Flaschen oder so genannte Schalenurnen fabriziert wurden ${ }^{31}$.

Es ist der Ausgräberin zuzustimmen, dass aufgrund dieser Massierung römischen Know-hows davon ausgegangen werden muss, dass Handwerker aus dem Imperium Romanum in Haarhausen gearbeitet haben. Ob ihr jedoch auch mit der weiteren Schlussfolgerung recht zu geben ist, nämlich dass die Töpfer die Provinz verließen, um ein sicheres Arbeitsumfeld zu finden und neue Absatzmärkte zu erschließen, ist fraglich ${ }^{32}$. Ausgangspunkt für diese Überlegung ist eine Stelle bei Tacitus, die besagt, dass die Hermunduren in einer besonderen Beziehung zum Imperium standen und auch Vorrechte beim Handel mit dem Römischen Reich genossen ${ }^{33}$. Abgesehen davon, dass die von Tacitus geschilderten Verhältnisse nicht mit denen des fortgeschrittenen 3. Jahrhunderts übereinstimmen müssen und ganz zu schweigen von den Schwierigkeiten, mit ,Stämmen' als festen Gruppen zu operieren, ist es nicht wahrscheinlich, dass die, Römer' ganz ohne fremde Hilfe gearbeitet haben können, da Dušeks Ansatz die Notwendigkeit unterschlägt, dass die Infrastruktur Arbeitskräfte, Rohmaterialien usw. - für ortsunkundige Neuankömmlinge von den Einheimischen zur Verfügung gestellt werden mussten ${ }^{34}$. Aber auch die andere bisher geäußerte These, dass es sich um kriegsgefangene Provinziale gehandelt habe, die nach Germanien verschleppt wurden, aber trotzdem die Gefäße römischen Typs für den eigenen Bedarf hergestellt hätten, ist nicht restlos überzeugend ${ }^{35}$. Vor allem ist gegen diese Hypothese anzuführen, dass die zwangsverschleppten Töpfer doch über einen nicht wirklich begründbaren großen Handlungsspielraum verfügt haben müssten. Beide Annahmen sehen die Handlungsmacht vor allem bei den römischen Handwerkern, während die indigenen Akteure zu wenig berücksichtigt werden. Die entscheidende Kraft

31 Steidl, „Drehscheibenkeramik,“ S. 105f.

32 Dušek, Haarhausen, S. 132-148.

33 Tac. Ger. 41.

34 Eine ethnologische Deutung römischer Schriftquellen insbesondere über einen mehrere Jahrhunderte dauernden Zeitraum wird mittlerweile von der Forschung abgelehnt. Zum problematischen ,ethnologischen' Konzept der ,Stämme' wie der Hermunduren: Tom Moore, "Detribalizing the Later Prehistoric Past: Concepts of Tribes in Iron Age and Roman Studies," Journal of Social Archaeology 11 (2011), 334-360.

35 So jedoch B. Schmidt, „Drehscheibenkeramik der spätrömischen Kaiserzeit und frühen Völkerwanderungszeit im Mittelelb-Saalegebiet," in Römerzeitliche Drehscheibenkeramik im Barbarikum. Symposium Weimar, 21. bis 25. Mai 1984, hrsg. Rudolf Feustel, Weimarer Monografien zur Ur- und Frühgeschichte 11 (Weimar, 1984) S. 26; Steidl, „Drehscheibenkeramik," S. 108-111. 
ist wohl eher in den einheimischen Eliten zu sehen, die für die Ansiedlung fremder Produzenten verantwortlich gemacht werden können, da sie allein über die Mittel verfügten, eine solch umfangreiche Produktion zu etablieren und mit der nötigen Infrastruktur auszustatten.

Eine wichtige Ergänzung erfuhren die Befunde in Haarhausen durch die Forschungen Bernd Steidls zu römischen Funden in Mainfranken, durch die eine von Haarhausen unabhängige, aber gleichzeitige Produktion von Drehscheibenkeramik nachgewiesen wurde $^{36}$. Der Töpferbetrieb konnte zwar bisher nicht identifiziert werden, doch sprechen Altfunde für eine Lokalisierung in Eßleben bei Schweinfurt ${ }^{37}$. Weil jedoch die Töpferöfen und auch die sonstige Infrastruktur samt Brennhilfen unbekannt sind, kann nicht davon ausgegangen werden, dass sie wie in Haarhausen römischer Technologie folgten. Sicher ist jedoch, dass Drehscheibenkeramik in römischer Machart hergestellt wurde. Detaillierte Untersuchungen an der stark fragmentierten Keramik ergaben signifikante Modifikationen bei der Produktion ${ }^{38}$ :

1.) Die Magerung der Gefäße ist nicht einheitlich. Sie kann teilweise sehr fein sein und somit dem römischen Usus entsprechen, aber auch aus gröberen Material bestehen und daher eher der germanischen Praxis folgen

2.) Die Behandlung der Oberfläche variiert stark. Neben unbehandelten Oberflächen kommt auch Glättung mit einem Polierstein vor, wie sie für germanische Terra nigra-Keramik üblich ist.

3.) Der Brand erfolgte in reduzierender Atmosphäre, so dass sich die Gefäße - wie auch die Haarhausener Stücke - in der Farbe deutlich von oxidierend gebrannter, also orange-roter Keramik unterscheiden, wie sie für provinzialrömische Produktion charakteristisch ist.

4.) Allgemein orientierte man sich bei der Formenwahl eher an römischen Traditionen. Exakte Parallelen für die einzelnen Gefäßtypen in den benachbarten römischen Provinzen ließen sich jedoch nicht feststellen.

5.) Typisch römische Gefäßformen werden signifikant verändert, wie man besonders gut an drei mortaria aus Eßleben und Frankenwinheim sehen $\mathrm{kann}^{39}$. Sie weisen einen Standring auf, der bei originalen römischen Reibschalen selten vorkommt. Zudem wurde die Arbeitsfläche im Inneren signifikant umgestaltet: Die Reibfläche im Inneren wurde

36 Steidl, „Drehscheibenkeramik,“ S. 87-116.

37 Steidl, „Drehscheibenkeramik,“ S. 105.

38 Steidl, „Drehscheibenkeramik," S. 98-100.

39 Steidl, „Drehscheibenkeramik,“ S. 92 Nr. 11 Abb. 3, 11; 94 Nr. 36-37 Abb. 4, 36-37; 99 Taf. 8, $11.36-37$. 
anstelle von grobem mit feinem Sand bestreut, zudem tief in die Wandung eingedrückt und teilweise mit Ton überschmiert. Dies bedeutet, dass die Gefäße nicht in ihrer sonst üblichen Funktion als Reibschalen verwendet werden konnten.

Diese Modifikationen zeigen, dass sich die Gefäße von römischen Vorbildern unterschieden und dass folglich auch die Herstellungsprozesse differierten. Steidl nimmt auch für die mainfränkischen Betriebe an, dass hier römische Gefangene als Töpfer tätig waren ${ }^{40}$. Dies ist möglich, doch sind die geschilderten Anpassungen nicht denkbar, ohne dass eine enge Interaktion mit indigenen Handwerkern auch im Sinne einer Zusammenarbeit stattgefunden hat. Vielleicht ist doch an Technologietransfer durch römisch ausgebildete germanische Töpfer zu denken, zumal anders als in Haarhausen der Beweis dafür fehlt, dass auch komplizierte Produktionseinrichtungen wie Töpferöfen exakt nach römischen Vorlagen errichtet wurden.

\subsubsection{Bleigewinnung}

Eine der für Technologietransfer wichtigsten archäologischen Entdeckungen in den letzten Jahren ist der Nachweis, dass im rechtsrheinischen Germanien sowohl unter römischer Verwaltung als auch nach Abzug römischer Truppen über den Rhein Blei produziert wurde ${ }^{41}$. Bereits kurz nach den augusteischen Feldzügen muss die Ausbeutung von entsprechenden Lagerstätten im Bergischen Land bei Bonn und vor allem im Hochsauerland bei Brilon eingesetzt haben ${ }^{42}$. Da Bleigewinnung in der vorrömischen Zeit nicht nachgewiesen ist und anscheinend abrupt begann, ist davon auszugehen, dass römische Prospektoren den Legionen unmittelbar folgten oder sogar vorausgegangen sind.

Das unter römische Verwaltung gewonnene Blei wurde über Gallien nach Rom bzw. an das Mittelmeer geschafft, wie dies Schiffswracks in Südfrankreich

40 Steidl, „Drehscheibenkeramik,“ S. 108-111.

41 Zum Bleibergbau in Germanien allgemein: Walter Melzer, Torsten Capelle (Hrsg.), Bleibergbau und Bleiverarbeitung während der römischen Kaiserzeit im rechtsrheinischen Barbaricum, (Soester Beiträge zur Archäologie) 8 (Soest, 2007) (im Folgenden zitiert als Melzer, Capelle, Bleibergbau).

42 Zum Bergbau auf dem Lüderich im Bergischen Land: Gabrielle Körlin, Michael Gechter, „Römischer Bergbau auf dem Lüderich. Vorbericht über die Grabungen 2000 bis 2002," in Man and Mining - Mensch und Bergbau. Studies in Honour of G. Weisgerber on Occasion of his 65th Birthday, hrsgg. Thomas Stöllner u. a. (Bochum, 2003) S. 237-248. 
bei Saintes Maries-de-la-mer und Sardinien beweisen ${ }^{43}$. Die Stempel auf den Bleibarren zeigen, dass sowohl der Kaiser selbst als auch private Unternehmer die Vorkommen ausbeuteten ${ }^{44}$. Die Herkunft aus Germanien ist sowohl durch das Kürzel GERM für plumbum germanicum als durch neue naturwissenschaftliche Untersuchungen gesichert ${ }^{45}$. Die Bleibarren haben die übliche römische Form, wie wir sie auch aus Britannien oder Spanien kennen, und folgen auch dem römischen Standardgewicht von 195 römischen Pfund $(=64 \mathrm{~kg})^{46}$.

Durch Lesefunde, aber auch durch Ausgrabungen in germanischen Siedlungen sind aber auch zahlreiche kleinere Bleibarren bekannt ${ }^{47}$, die wesentlich leichter als ihre römischen Gegenstücke sind, nämlich nur 300 bis $600 \mathrm{~g}$, wobei das Gewicht stark variieren $\mathrm{kann}^{48}$. Auch formal unterscheiden

43 Françoise Laubenheimer-Leenhardt, Recherches sur les lingots de cuivre et de plomb d'époque romaine dans les regions de Languedoc-Roussillon et de Provence-Corse, 3, (Supplément Revue Archéologique Narbonnaise) 3 (Paris, 1973) S. 124f. Nr. 16; 195-197; Norbert Hanel, Peter Rothenhöfer, „Germanisches Blei für Rom. Zur Rolle des römischen Bergbaus im rechtsrheinischen Germanien im frühen Prinzipat," Germania 83 (2005), 58-6o; Norbert Hanel, Peter Rothenhöfer, „Römische Bleigewinnung im Raum Brilon und der Bleitransport nach Rom, "in: Melzer, Capelle, Bleibergbau, S. 41-46.

44 Als private Unternehmer sind Flavius Verucla und Pudens bezeugt: Norbert Hanel, Peter Rothenhöfer, „Germanisches Blei für Rom. Zur Rolle des römischen Bergbaus im rechtsrheinischen Germanien im frühen Prinzipat," Germania 83 (2005), 59 .

45 Inschrift: Norbert Hanel, Peter Rothenhöfer, „Römische Bleigewinnung im Raum Brilon und der Bleitransport nach Rom," in: Melzer, Capelle, Bleibergbau, S. 42-44; naturwissenschaftliche Untersuchungen: Michael Bode, Archäometallurgische Untersuchungen zur Blei-/Silbergewinnung im Germanien der frühen Römischen Kaiserzeit (Münster, 2008) S. 134-138 Abb. 5.8. 5.9.

46 Zur Typologie römischer Bleibarren: Claude Domergue, Les mines de la Péninsule ibérique dans l'antiquité romaine (Collection École Française de Rome) 127 (Rom, 1990) S. 253f.; Norbert Hanel, Peter Rothenhöfer, „Germanisches Blei für Rom. Zur Rolle des römischen Bergbaus im rechtsrheinischen Germanien im frühen Prinzipat," Germania 83 (2005), 58 f. $\mathrm{Zu}$ Bleifunden in indigenen Siedlungen der älteren Römischen Kaiserzeit: Peter Rothenhöfer, „Das Blei der Germanen. Bemerkungen zu einer neuen Fundgattung und zur Aufnahme der Bleiproduktion durch Germanen während der älteren Römischen Kaiserzeit in Westfalen," Archäologisches Korrespondenzblatt 34 (2004), 423; Peter Rothenhöfer, „Iam et plumbum excoquere docuimus? - Zum Phänomen der germanischen Bleiproduktion im nördlichen Sauerland während der römischen Kaiserzeit," in Melzer, Capelle, Bleibergbau, S. 47-49 Abb. 2 (Übersicht); Martin Straßburger, „Plumbi nigri origo duplex est - Bleierzbergbau der römischen Kaiserzeit im nordöstlichen Sauerland," in Melzer, Capelle, Bleibergbau, S. 6o-62; Bode, Untersuchungen, S. 112f.

48 Rothenhöfer, „Blei der Germanen,“ S. 423-426 Abb. 2; Peter Rothenhöfer, „Iam et plumbum excoquere docuimus? - Zum Phänomen der germanischen Bleiproduktion im nördlichen Sauerland während der römischen Kaiserzeit," in Melzer, Capelle, Bleibergbau, 
sie sich deutlich von diesen Standardbarren, da sie einen trapezförmigen bis rechteckigen Umriss besitzen und an einer Schmalseite eine Durchbohrung aufweisen. Anders als man lange Zeit glaubte, gehören diese Barren nicht in das Mittelalter, sondern sind aufgrund des Fundkontextes in die römische Kaiserzeit, genauer in das 1. und 2. Jahrhundert n. Chr., vielleicht auch noch in das 3. Jahrhundert n. Chr., zu datieren ${ }^{49}$. Die Zeitstellung und die vollkommen andere Gestaltung der Barren sprechen also für eine nicht-römische, das heißt germanische Bleiproduktion, die aufgrund fehlender eigener Tradition auf römischer Bergbau- und Verhüttungstechnologie fußen muss. Im Einzelnen waren folgende Arbeitsschritte zur Gewinnung von Blei aus Bleiglanz, dem lokal vorkommenden Erz, erforderlich ${ }^{50}$ :

- Prospektion und Abbau des Erzes

- trockenmechanische Aufbereitung

- Schweretrennung im Wasser

- Rösten des Erzes

- Reduktion des Bleioxids zu Blei

- Weiterverarbeitung zu Barren

Der Arbeitsvorgang ist aufwändig, aber nicht besonders schwierig, so dass ein Technologietransfer durch Nachahmung möglich gewesen sein kann, beispielsweise dadurch, dass indigene Arbeitskräfte durch ihre Tätigkeit in römischen Betrieben sich das entsprechende Know-how abgeschaut haben ${ }^{51}$. Freilich ist davon auszugehen, dass die Technik im Einzelnen abgewandelt wurde. Unklar muss bleiben, ob sich die Abbautechniken verändert haben, da sicher mit diesem germanischen Abbau zu verbindende Spuren noch

S. 47-51 Abb. 1. 3. 4. 6; 54f. (Katalog). Vgl. auch Michael Erdrich, „Rezension zu Walter Melzer - Torsten Capelle (Hrsg.), Bleibergbau und Bleiverarbeitung während der römischen Kaiserzeit im rechtsrheinischen Barbaricum," Germania 87 (2009), 629.

49 Dies gilt für die Fundorte Salzkotten-Thüle, Balve-Garbeck, Brilon-Fülsenbecke und vor allem Soest: Bode, Untersuchungen, S. 112 (mit der weiteren Lit.). Zur Datierung: Peter Rothenhöfer, „Iam et plumbum excoquere docuimus? - Zum Phänomen der germanischen Bleiproduktion im nördlichen Sauerland während der römischen Kaiserzeit," in Melzer, Capelle, Bleibergbau, S. 51; Martin Straßburger, „Plumbi nigri origo duplex est Bleierzbergbau der römischen Kaiserzeit im nordöstlichen Sauerland," in Melzer, Capelle, Bleibergbau, S. 6o-62.

5o Zu technisch-chemischen Vorgängen der Bleigewinnung: Bode, Untersuchungen, S. 8-10.

51 Peter Rothenhöfer, „Iam et plumbum excoquere docuimus? - Zum Phänomen der germanischen Bleiproduktion im nördlichen Sauerland während der römischen Kaiserzeit," in Melzer, Capelle, Bleibergbau, S. $5^{2 f}$. 
nicht entdeckt wurden ${ }^{52}$. Die nächsten Produktionsschritte müssen jedenfalls gleich geblieben sein, da sonst nicht das gewünschte Ergebnis - Blei hätte erzielt werden können. Denkbar sind freilich kleinere Modifikationen bei einzelnen Komponenten wie Werkzeugen. Die größte Veränderung, die eindeutig archäologisch nachweisbar ist, betrifft den letzten Arbeitsgang, die Weiterverarbeitung zu Barren, da deren Form sich deutlich von den römischen Barren unterscheidet. Das kleinere Gewicht und die fehlende Standardisierung sprechen für einen geringeren Grad bei der Organisation des germanischen Bleiabbaus, da vielleicht jeder einzelne Betrieb seine eigene Barrengröße wählte, und für eine schlechtere Infrastruktur entweder bei der Bleiproduktion selbst, da nur kleinere Mengen Blei gewonnen wurden oder bei der Verkehrserschließung, weil leichtere Barren natürlich auch einfacher zu transportieren waren. Der letzte Aspekt ist deswegen wichtig, weil das gewonnene Blei mit hoher Wahrscheinlichkeit in das Imperium Romanum verhandelt wurde, obwohl auch sporadisch indigene Buntmetallverarbeitung im rechtsrheinischen Germanien nachgewiesen werden kann ${ }^{53}$.

\subsection{Fezzan}

Als eine besonders ergiebige Region für den Nachweis von Technologietransfer erwies sich der Fezzan, obwohl diese hyperaride Region im südlichen Libyen besonders weit vom Imperium Romanum entfernt war. Der Fezzan (Oase alAjal) gehörte während der gesamten Antike, also von ca. $500 \mathrm{v}$. Chr. bis $500 \mathrm{n}$. Chr., zum Siedlungsgebiet der Garamanten, und hatte sein politische Zentrum in Gerama (Jarma), das ungefähr 10ookm von der Küste des Mittelmeers entfernt liegt, was einer Reise von 30 Tagen mit einer Karawane entspricht ${ }^{54}$. Aufgrund intensiver archäologischer Feldforschungen während der italienischen Okkupation in den 3oer Jahren und libysch-britischer Forschungen seit den 7oer Jahren des letzten Jahrhunderts ist die materielle Kultur der Garamanten gut bekannt ${ }^{55}$.

52 Martin Straßburger, „Plumbi nigri origo duplex est - Bleierzbergbau der römischen Kaiserzeit im nordöstlichen Sauerland," in Melzer, Capelle, Bleibergbau, S. 62 f.

Bleiverarbeitung vor allem in Soest bezeugt: hier Anm. 47. Verhandlung in das Imperium: Erdrich, „Rezension,“ S. 629f. Kritisch: Martin Straßburger, „Plumbi nigri origo duplex est Bleierzbergbau der römischen Kaiserzeit im nordöstlichen Sauerland," in Melzer, Capelle, Bleibergbau, S. 65-68.

54 Zum Fezzan allgemein: Nick Brooks u. a., "Studies in Geography, Geomorphology, Environment and Climate," in The Archaeology of Fazzan. Volume 1, Synthesis, hrsg. David J. Mattingly (London - Tripoli, 2003) S. 37-74 (im Folgenden zitiert als Mattingly, Synthesis). Erwin W. Ruprechtsberger, Die Garamanten. Geschichte und Kultur eines libyschen Volkes in der Sahara. Sonderhefte Antike Welt (Mainz 1997), S. 29-50; David J. Mattingly - Tim 
Die Ausgrabungen in Gerama deckten eine Siedlung auf mit durchaus urbanem Charakter, die neben einfacheren Strukturen aus einer zentralen Gruppe von Gebäuden bestand, die aus Lehmziegeln auf sorgfältig aus Quadern konstruierten Steinsockeln errichtet wurden ${ }^{56}$. Wie im pannonischen Limesvorland wurde auch im Fezzan römische Bautechnik angewandt ${ }^{57}$. Die Übernahme ging jedoch auch in Gerama noch weiter: Bei Ausgrabungen in Nähe des Gebäudes GER 1.3 wurde seit 2001 eine größere Anzahl von Hypokaust-Ziegeln und Tubuli zusammen mit Fragmenten von bemaltem Wandputz und hydraulischem Zement gefunden ${ }^{58}$. Die Funde belegen somit zweifelsfrei, dass es mitten in Gerama eine Thermenanlage römischen Stils samt einer Hypokaustenheizung und Wasserbecken gegeben haben muss. Nichts weist daraufhin, dass diese Spezialformen von Ziegeln und Mörtel lokal produziert wurden, das Baumaterial muss also zumindest zum überwiegenden Teil von der Africa proconsularis durch die Wüste in den Fezzan transportiert worden sein.

Zur gleichen Zeit wurden im Fezzan weitere neue Techniken eingeführt, die sich jedoch auf einem vollständig anderen Niveau abspielten. So wurde die Reibmühle, die lokal seit dem Neolithikum im Gebrauch war, im Fezzan seit dem späten 1. Jahrhundert $n$. Chr. durch die Drehmühle ersetzt oder zumindest ergänzt ${ }^{59}$. Da weder in der Sahara noch in Afrika südlich der Sahara diese

Reynolds - John Dore, Synthesis of Human Activities in Fazzan, in: Mattingly, Synthesis, S. 327-373; David J. Mattingly - Andrew I. Wilson, "Concluding Thoughts: made in Fazzan?" in The archaeology of Fazzan. Volume 3, Excavations of C.M. Daniels, hrsg. David J. Mattingly (London - Tripoli, 2010) S. 523-530 (im Folgenden zitiert als Mattingly, Excavations).

56 Zu Gerama: Mahmoud S. Ayoub, Excavations at Germa, the Capital of the Garamantes. Preliminary Report (Tripoli, 1962); ders., Excavations in Germa between 1962 and 1966 (Tripoli, 1967); ders., The Rise of Germa: 100-450 A.D., in Libya in History. Historical Conference 16.-23. March 1968, hrsg. Fawzi F. Gadallah (Benghazi, 1968) S. 194-204; Ruprechtsberger, Garamanten, S. 30-36; David J. Mattingly u. a., in The Archaeology of Fazzan. Volume 2, Site Gazetteer, Pottery and Other Survey Finds, hrsg. David J. Mattingly (London - Tripoli, 2007) S. 115-118 .

57 David Mattingly, "Fortifications, settlement and domestic architecture," in Mattingly, Synthesis, S. 163-165; Andrew Wilson, "Saharan Trade in the Roman Period: Short-, Medium- and Long-Distance Trade Networks," Azania: Archaeological Research in Africa 47 (2012), 427.

58 David Mattingly, "Fortifications, Settlement and Domestic Architecture," in Mattingly, Synthesis, S. 165; Wilson, "Trade," S. 428.

59 Mattingly, Synthesis, S. 36o; David J. Mattingly, Andrew I. Wilson, "Concluding Thoughts: Made in Fazzan?," in Mattingly, Excavations, S. 528; Wilson, “Trade," S. 428. 
Art von Mühle so früh bezeugt ist, muss diese technische Weiterentwicklung aus dem Imperium Romanum stammen.

Eine vergleichbare technische Aneignung fand auch im Bereich der Textilverarbeitung statt. In jüngster Zeit wurden in Saniat Jibril und Aghram Nadarif Webgewichte entdeckt, wodurch der Gebrauch des Gewichtswebstuhls seit dem 1. Jahrhundert $n$. Chr. für den Fezzan gesichert ist ${ }^{60}$. Auch hier ist die Einfuhr durch den Austausch mit dem Imperium Romanum am wahrscheinlichsten. Weitere Funde zeigen, dass der Gewichtswebstuhl bis in das 4. Jahrhundert im Fezzan üblich war ${ }^{61}$. Interessant ist dabei, dass die nächste Stufe in der Entwicklung des Webstuhls, der Rahmenwebstuhl, nicht eingeführt wurde, obwohl dieses Gerät, bei dem ein zweiter Webbalken die Webgewichte ersetzte, im Imperium Romanum bereits seit dem späten 1. Jahrhundert $\mathrm{n}$. Chr. den Gewichtswebstuhl verdrängte ${ }^{62}$. Anscheinend war der technologische Fortschritt und die dadurch bedingte komfortablere Handhabung für die Garamanten nicht von entscheidender Bedeutung, oder die Neuerung gelangte aus unbekanntem Grund nicht mehr in den Fezzan ${ }^{63}$.

\section{$2.4 \quad$ Reich Herodes des Großen}

Weitere Beispiele fürTechnologietransferstammen aus dem Herrschaftsbereich Herodes des Großen, also aus einem der während der späten Republik und der frühen Kaiserzeit recht häufigen Klientelstaaten in der östlichen Peripherie des Imperium Romanum ${ }^{64}$. Im Zentrum des Interesses steht der zweite

$60 \quad$ Saniat Jibril: David J. Mattingly - John Hawthorne - Charles M. Daniels, in: Mattingly, Excavations, S. 194-197 Abb. 3.83; 3.84; Aghram Nadharif: L. Mori, "The Loom Weights," in Aghram Nadharif. The Barkat Oasis (Sha'abiya of Ghat, Libyan Sahara) in Garamantian times, hrsg. Marco Liverani (Florenz, 2005) S. 319-321; Wilson, "Trade," S. 428.

61 David J. Mattingly, Andrew I. Wilson, “Concluding Thoughts: Made in Fazzan?," in Mattingly, Excavations, S. $5^{28}$.

62 Zur Technologie von Webstühlen im Imperium Romanum zusammenfassend: John P. Wild, "Textile Production," in The Oxford Handbook of Engineering and Technology in the Classical World, hrsg. John P. Oleson (Oxford, 2008) S. 465-482 (mit Belegen).

63 Weites wurden Weinpressen mediterranen Typs im Fezzan eingeführt: Wilson, "Trade," S. 428.

64 Nikos Kokkinos (Hrsg.), International Conference The World of the Herods and the Nabataeans: held at the British Museum, 17-19 April 2001. 1. The World of the Herods (Stuttgart, 2007); ,Zur materiellen Kultur im Klientelreich Herodes' des Großen: Günther Schörner, „Rom jenseits der Grenze: Klientelkönigreiche und der Impact of Empire,“ in Frontiers in the Roman World. Proceedings of the Ninth Workshop of the International Network Impact of Empire, hrsgg. Olivier Hekster, Ted Kaizer (Hrsg.), (Leiden - Boston 2011) S. 124-130. 
Winterpalast Herodes des Großen bei Jericho im Jordantal, der zusammen mit den hasmonäischen und zwei weiteren herodianischen Bauten von 1973 bis 1987 aufgedeckt wurde ${ }^{65}$. Die Anlage wurde nach einem Erdbeben im Jahre 31 v. Chr. erbaut und besteht aus zwei Teilen, die miteinander durch eine breite Treppe verbunden sind ${ }^{66}$. Das Zentrum des Nordflügels bildet ein Peristyl, während im Süden zwei Wasserbecken, ein Garten und ein Bad liegen. Dieser Trakt umfasst neben einem Korridor ein Praefurnium, ein Caldarium, ein Tepidarium, ein Frigidarium sowie eine Latrine und ist somit deutlich römischen Vorbildern verpflichtet ${ }^{67}$. Dennoch gibt es einige signifikante Abweichungen: So wurde das Warmbad zwar mit einer Hypokaustenheizung ausgestattet, doch waren die Stützpfeiler nicht wie in den meisten anderen römischen Bädern aus Ziegeln aufgemauert, sondern bestanden aus lokalem Kalkstein, so dass in diesem Punkt eine Anpassung an die lokale Baupraxis vorliegt ${ }^{68}$. Wesentlich tiefgreifender ist die folgende Adaption: Raum $\mathrm{A}(\mathrm{L})$ 346 sieht aufgrund des umlaufenden Kanals aus wie eine normale römische Latrine, doch fehlt sowohl eine Frischwasserzuführung als auch eine Abwasserableitung69. Trotz dieses gravierenden Unterschieds zu den meisten römischen Anlagen ist die Interpretation als Toilette für den Ausgräber Ehud Netzer nicht in Zweifel zu ziehen, da der Grundriss, die Lokalisierung und das Fehlen eines Raums als Alternativlösung für diese Nutzung sprechen ${ }^{70}$. Zur Erklärung der fehlenden Wasserleitungen und somit allgemein des Verzichts auf Wasser beim Betrieb der Latrine führt Netzer an, dass nach jüdischer Tradition Exkremente auf den Feldern entsorgt werden sollen, was im herodianischen Palast mit Hilfe von Körben oder anderen tragbaren Gefäßen geschah $^{71}$. Der Verzicht auf Wasser ist eine Folge kultureller Vorgaben, da

65 Ehud Netzer, Hasmonean and Herodian Palaces at Jericho. Final Reports of the 1973-1987 Excavations. Volume I: Stratigraphy and Architecture (Jerusalem, 2001) (im Folgenden zitiert als Netzer, Stratigraphy); jüngste Zusammenfassung zu den Palastanlagen: Kathryn Gleason, Rachel Bar-Nathan, „Paradeisoi of the Palace Complex at Jericho“, in Hasmonean and Herodian Palaces at Jericho. Final Reports of the 1973-1987 Excavations. Volume V: The Finds from Jericho and Cypros (Jerusalem, 2013) S. 325-347.

66 Netzer, Stratigraphy, S. 7f. (Datierung).

67 Zum Bad: Netzer, Stratigraphy, S. 186f. Plan 30; 211-214. Korridor: A(L) 341; Frigidarium: A(L) 345; Latrine: A(L) 346; Caldarium: E 4/1; tepidarium: E 4/2; Praefurnium: E 4/10.

68 Netzer, Stratigraphy, S. 213 Taf. 8.

69 Netzer, Stratigraphy, S. 211-212 Abb. 303. 304.

$70 \quad$ Netzer, Stratigraphy, S. 212.

71 Netzer, Stratigraphy, S. 212. Vgl. auch Zena Kamash, „Perceptions of Latrines: Sociocultural, Moral and Religious Issues," in Roman Toilets. Their Architecture and Cultural History, hrsgg. Gemma C.M. Jansen - Ann O. Koloski-Ostrow - Eric M. Moormann, 
religiös begründete Gebote und Verbote die entscheidende Begründung liefern, und keine Frage der technischen Fähigkeiten. Innerhalb eines größeren technischen Komplexes - einem Bad nach römischem Muster - wurde für eine Komponente also eine eigene kulturspezifische technische Lösung gewählt ${ }^{72}$.

\section{$3 \quad$ Übergreifende Überlegungen}

\subsection{Räumlich und zeitliche Charakteristika}

Die Ausfuhr von Waren und Praktiken, und somit auch von Techniken aus dem Imperium Romanum lässt bestimmte Regelmäßigkeiten erkennen. So zeigt die Präsenz römischer Artefakte bei Gesellschaften außerhalb des Römischen Reichs, dass diese Regionen zum Hinterland oder zumindest zur Einflusssphäre des Imperium Romanum gehörten. Für die Region nördlich der Donau im heutigen Mähren und der Slowakei prägten Jan Bouzek und Iva Ondřejová den Terminus třety zóna (dritte Zone), um die enge Verbundenheit mit dem Römischen Reich auch terminologisch zum Ausdruck zu bringen ${ }^{73}$. Folglich wurde Technologie exportiert zu oder importiert von den Gruppen, die die engsten Beziehungen und somit direkten Kontakt zu Rom hatten. Hierin besteht ein wichtiger Unterschied zur Ausfuhr römischer Objekte in das Barbaricum, der auch über Mittelsmänner erfolgen konnte. Grundsätzlich gilt jedoch, dass Technologietransfer immer auch mit einem Export von Waren verbunden ist. Geographische Nähe scheint für diese Form des Austauschs

Supplement Bulletin Antieke Beschaving 19 (Leuven, 2011) S. 186f. (im Folgenden zitiert als Jansen u. a., Toilets); dies., "An Exploration of the Relationship between Shifting Power, Changing Behaviour and New Water Technologies in the Roman Near East," Water History 4 (2012), 88. Sammlung der Quellen: Stefanie Hoss, "Jewish and Christian Texts on Ancient Latrines," in Jansen u. a., Toilets, S. 47-50; zur Situation in Palaestina allgemein: dies., "Palestine," in Jansen u. a., Toilet, S. 184f. Auch andernorts konnte vor allem im privaten Bereich auf Spülung durch Anschluss an eine Wasserleitung verzichtet werden, doch benutzte man dann Wasser, das in Eimer bereit gestellt wurde: Gemma C.M. Jansen, Antonella Merletto, „Water Use and flushing Activities,“ in Jansen u. a., Toilets, S. 73-76. (frdl. Hinweis von Richard J. Talbert).

72 Grundlegend zur Ablehnung von Technik aus kulturellen Gründen vgl. die Fallstudie: Georges Guille-Escuret, "Technical Innovation and Cultural Resistance: The Social Weight of Plowing in the Vineyards of Les Corbières (Languedoc)," in Technological Choices: Transformation in Material Cultures since the Neolithic, hrsg. Pierre Lemonnier (London New York, 1993) S. 214-226.

73 Jan Bouzek, Iva Ondřejová, „Třetí zóna“ mezi Římem a barbarikem,” Archeologické rozhledy $42 / 1$ (1990), 22-35. 
keine Voraussetzung gewesen zu sein, wie man im Fall des Fezzan sieht, der eine Karawanenreise von mehreren Wochen vom Imperium Romanum entfernt war ${ }^{74}$.

Die betrachteten Fallbeispiele für Technologietransfer fanden zu unterschiedlicher Zeit statt, im späten 1. Jahrhundert v. Chr. in Iudaea, im 1. Jahrhundert beim Bleibergbau in Germanien, im späten 1. Jahrhundert n. Chr. im Fezzan, in der 2. Hälfte des 3. Jahrhunderts bei der Keramikherstellung in Germanien, im 3. und den ersten Jahrzehnten des 4. Jahrhunderts für römische Bau- und Heiztechnik in der Slowakei. Der Zeitraum, in dem der Technologietransfer stattfindet, wird bestimmt durch die Intensität der Kontakte zwischen Zielregionen und Imperium Romanum: So sind die Bande zwischen Herodes und Rom evident ${ }^{75}$. Für den Fezzan sind Konflikte mit dem Imperium für das spätere 1. Jahrhundert überliefert: Die Garamanten hatten Lepcis Magna geplündert und wurden durch Gaius Valerius Festus in der Regierungszeit Vespasians, wie Tacitus schreibt ${ }^{76}$, zurückgeschlagen. Es ist deshalb plausibel, die Intensivierung der Beziehungen zu dieser Region als die Bemühungen zu interpretieren, eine Art der Vorfeldverteidigung zu etablieren ${ }^{77}$. Zweifelsfrei ist, dass in den Gräbern im Fezzan besonders viele Terra sigillata-Gefäße gefunden wurden, die in dieser Phase produziert wurden ${ }^{78}$. Auch in Germanien folgt Technologietransfer einem ähnlichen Muster: Die Entwicklung germanischen Bleibergbaus folgt auf eine intensive

74 René Rebuffat, "Les Romains et les routes caravanières," in Le Sahara, lien entre les peubles et les cultures. Actes du Colloque organisé à Douz du 19 au 22 décembre 2002 (Tunis, 2004) S. 221-260. Vgl. hier auch den Beitrag von Wim Broekaert und Wouter Vanacker.

75 Vgl. hier Anm. 64. Hierzu gehört auch - als ein weiteres Beispiel für Technologietransfer die Verwendung von opus caementicium beim Bau des Hafens von Caesarea: Graham Branton, John P. Oleson, „The Technology of King Herod's Harbour," in Caesarea Papers. Straton's Tower; Herod's Harbour and Roman and Byzantine Caesarea, hrsg. Robert L. Vann, Suppl. Journal of Roman Archaeology 5 (Portsmouth, Rhode Island, 1992) S. 46-67.

76 Tac. Hist. IV 49.

77 Zu den Beziehungen zwischen Garamanten und Imperium Romanum: Mark Milburn, "Romans and Garamantes - an Enquiry into Contacts," in Town and Country in Roman Tripolitania. Papers in Honour of Olwen Hackett, hrsgg. David J. Buck - David J. Mattingly (Oxford, 1985) S. 241-261.

78 Sergio Fontana, "I manufatti romani nei corredi funerari del Fezzan. Testimonianze dei commerci e della cultura dei Garamanti (I-III sec. d. C.)," in Productions et exportations africaines: actualités archéologiques en Afrique du Nord antique et mediévale. VI ${ }^{e}$ Colloque Internationale sur l'Histoire et l'Archéologie de l'Afrique du Nord (Pau, octobre $1993-118^{e}$ congrès), hrsg. Pol Trosset (Paris, 1995) S. 405-420; Erwin W. Ruprechtsberger, Die Garamanten. Geschichte und Kultur eines libyschen Volkes in der Sahara. Sonderhefte Antike Welt (Mainz, 1997) S. 27.65. 
Interaktionsphase, die nicht mit der Varus-Niederlage endete, sondern unter Tiberius und seinen Nachfolgern fortgesetzt wurde ${ }^{79}$. Noch intensiver waren Kontakte zwischen Imperium und ,Germanen' in der 2. Hälfte des 3. Jahrhunderts, da eine deutliche Zunahme von Importfunden in Germanien während der Existenz des Imperium Galliarum konstatiert werden konnte ${ }^{80}$. Auch die Bauten mit römischer Steinmetz- und Heiztechnik im pannonischen Limesvorland fanden zu einer Zeit statt, als es zu Auseinandersetzungen zwischen Römern und Gruppen außerhalb des Reiches kam ${ }^{81}$. Der an sich naheliegende Schluss ist also, dass Technologietransfer in Phasen besonders intensiven Kontakts stattgefunden hat, wobei dieser durchaus militärisch gewesen sein kann.

\subsection{Modalitäten des Technologietransfers}

3.2.1 Appropriate Technology - High Technology

Neben den räumlichen und zeitlichen Gegebenheiten ist Technologietransfer durch die Modalitäten des Austausches näher zu bezeichnen ${ }^{82}$. Nicht alle Möglichkeiten, wie römische Objekte über die Grenze gelangen konnten, ist für einen solchen Austausch geeignet. So kann beispielsweise ausgeschlossen

79 Zusammenfassend: Jan Bemmann, „Das rechtsrheinische Vorland im 1. Jahrhundert n. Chr.," in Krieg und Frieden. Kelten - Römer - Germanen. Ausstellungskatalog Rheinisches Landesmuseum Bonn (Bonn, 2007) S. 97-105 (mit Belegen); Peter S. Wells, Die Barbaren sprechen. Kelten, Germanen und das römische Europa (Darmstadt 2007) S. 133-160.

80 Jan Bemman, „Romanisierte Barbaren oder erfolgreiche Plünderer? Anmerkungen zur Intensität, Form und Dauer des provinzialrömischen Einflusses auf Mitteldeutschland während der jüngeren Römischen Kaiserzeit und der Völkerwanderungszeit," in Antyk i Barbarzyncy. Ksiega dedykowana Profesorowi Jerzemu Kolendo w siedemdziesiata rocznice urodzin, hrsgg.Aleksander Bursche, Renata Ciołek (Warschau 2003) S. 53-108; Andreas Rau, „Das nördliche Barbaricum zur Zeit der Krise des 3. Jahrhunderts n. Chr. - Einige kritische Anmerkungen zur Diskussion über provinzialrömischnordeuropäische Verbindungen," in Die Krise des 3.Jahrhunderts n. Chr. und das Gallische Sonderreich. Akten des Interdisziplinären Kolloquiums Xanten 26. bis 28. Februar 20og, hrsg. Thomas Fischer, Zakmira 8 (Mainz, 2012) S. 343-430; Fallbeispiel: Christoph G. Schmidt, "Just Recycled? New Light on the Roman Imports at the ,Central Farmstead" of Frienstedt (Central Germany)," in Wells, Rome beyond its Frontiers, S. 57-70 (mit weiterer Literatur).

81 z.B. Kristian Elschek, „Römisch-germanische villae rusticae im Limesvorfeld von Carnuntum? Ergebnisse systematischer Grabung und Prospektion," in: Roman Frontier Studies 1995 (Oxford, 1997) S. 228-232. Ein wichtiges Indiz sind die zahlreichen Importe von Keramik: Klára Kuzmová, Terra sigillata im Vorfeld des nordpannonischen Limes (Südwestslowakei) (Archaeologica Slovaca Monographiae Fontes) XVI (Nitra, 1997).

82 Thomas Grane, "Roman Imports in Scandinavia: Their Purpose and Meaning?," in Wells, Rome beyond its Frontiers, S. $3^{2-35}$. 
werden, dass die Tubuli und Hypokaustanlagen im römischem Stil als Beute in den Fezzan oder die Slowakei gelangten. Tributzahlungen, Handel oder Übergabe von diplomatischen Geschenken könnten realistischere Optionen für Technologietransfer sein, doch auch das kann - zu Recht - bezweifelt werden. In seinem Artikel ,How Technology Was Transferred in the Western Provinces' nennt Kevin Greene verschiedene Optionen als Medien des Transport innerhalb des Römischen Reichs ${ }^{83}$ : Fachliteratur wie ein Beispiel in Vitruvs ,Zehn Büchern über Architektur‘ auf uns gekommen ist, Handbücher für die Provinzialverwaltung, deren Existenz postuliert wird, auch wenn kein Beispiel erhalten blieb, private Firmen und vor allem das römische Militär. Von besonderer Bedeutung ist seine Feststellung, dass Technik nicht nur aus Geräten und Maschinen besteht, sondern auch aus Menschen, die diese bedienen können, so dass sich Technologietransfer nicht im Transport von Dingen erschöpft haben kann, sondern soziale Verbindungen vorausgesetzt werden müssen, die freilich heute für uns nur noch anhand ihrer materiellen Hinterlassenschaften erkennbar sind ${ }^{84}$.

Bei der Betrachtung von Technologietransfer wird eine Frage besonders virulent: Soll ein interner oder ein externer Standpunkt eingenommen werden? Oder: Ist von Technologie-export oder von Technologieimport zu sprechen? Eng verbunden ist die Frage nach der Handlungsmacht: Wer war verantwortlich für den Technologietransfer? Diese Fragen sind zwar für alle Formen der Übernahme und Adaption von Dingen von entscheidender Bedeutung, doch werden sie bei grenzüberschreitenden Praktiken besonders virulent, da Personen bzw. Gruppen involviert sind, die in ganz unterschiedlichen Räumen und unterschiedlichen sozialen Kontexten verortet sind.

Zur besseren Einschätzung, wie römische Technologie transportiert wurde, wie sie übernommen wurde und wie sie an lokale Bedürfnisse und lokale Vorstellungen angepasst wurde, sind moderne Forschungen zum Technologietransfer eine wichtige Quelle für Anregungen. Als geeignet erwiesen sich insbesondere Überlegungen, die im Rahmen der Entwicklungshilfe gemacht wurden, da sie zum einen von einem größeren technologischen

83 Kevin Greene, "How Technology Was Transferred in the Western Provinces," in Current Research on the Romanization of the Western Provinces, hrsgg. Mark Wood, Francisco M.V.R. Queiroga (London, 1992) S. 101-105.

$84 \mathrm{Zu}$ Netzwerken bei römischen Importen in das Barbaricum: Peter S. Wells, "Roman Imports in a Larger Context: Some Questions for Further Research," in Wells, Rome beyond its Frontiers, S. 123f. (mit Beispielen). 
Gefälle zwischen Ursprungs- und Nutzungsort ausgehen und zum anderen die Rolle der indigenen Gesellschaften betonen ${ }^{85}$.

Heuristisch besonders weiterführend ist insbesondere die Unterscheidung zwischen appropriate technology und high technology. Appropriate technology oder angemessene Technologie ist ein Begriff, der in den 7oer Jahren des 20. Jahrhunderts geprägt wurde ${ }^{86}$. Auf der Website der FAO, der Ernährungs- und Landwirtschaftsorganisation der UNO, wird diese angemessene Technologie definiert ${ }^{87}$ : „It can best be defined as fulfilling two essential criteria: 1) it must be sustainable; and 2) it must be locally accepted and adapted. Sustainability implies that whatever implement, tool or machine is added to a system to improve efficiency should be locally available, or can be produced locally. $[\ldots . . . . "$

Im Kontrast dazu ist high technology oder Hochtechnologie als besonders kostenintensiv und für die Gesellschaft, in der die Technologie transportiert wird, als besonders fremdartig zu sehen. Obwohl es sich in beiden Fällen um moderne Termini handelt, lassen sie sich gut auf unsere Fallstudien anwenden und helfen, Modi der Verbreitung und der Adaption sowie allgemein die Akzeptanz zu verstehen. Allgemein sind zwei Fragen für eine entsprechende Qualifizierung zu beantworten:

1.) Sind die vermittelten Technologien nachhaltig und wenn ja, in welchem Umfang?

2.) Wurden sie von den lokalen Gruppen angenommen und übernommen?

Die Fallstudien konnten freilich auch zeigen, dass nicht immer eindeutige Entweder-Oder-Entscheidungen getroffen werden können, sondern dass der Übergang von angemessener Technologie zur Hochtechnologie fließend sein kann, und deshalb die Einteilung zu schematisch ist. Zu fragen ist deshalb, wie

85 Ein Musterbeispiel für erfolgreichen Technologietransfer in der Moderne, der nicht nur auf technische, sondern auch auf soziale und kulturelle Aspekte eingeht, stellt die Simbabwe-Buschpumpe dar: Marianne de Laet, Annemarie Mol, „The Zimbabwe Bush Pump. Mechanics of a Fluid Technology," Social Studies of Science 30 (2000), 225-263.

86 Peter Dunn, Appropriate Technology: Technology with a Human Face (London, 1978); Greene, Technology Transferred," S. 102. Zu appropriate technology auch: Thomas P. Hughes, "The Evolution of Large Technological Systems," in The Social Construction of Technological Systems: New Directions in the Sociology and History of Technology, hrsgg. Wiebe Bijker, Thomas Hughes, Trevor Pinch (Cambridge, Massachusetts - London, 1987) S. 68-70.

87 <http://www.fao.org/docrep/x5596e/x5596eo6.htm\#TopOfPage> (o6.01.2014). 
Technologien, ihr Transfer und ihre Rezeption genauer charakterisiert werden können.

In Anlehnung an Arbeiten aus dem Feld der Science and Technology Studies, aber auch aus dem Bereich der Behavioral Archaeology, wurde deshalb ein Fragenkatalog entwickelt, um die Intensität der Einbindung und Auswirkungen der übernommenen Technologie auf die indigenen Gruppen besser einschätzen zu können ${ }^{88}$.

1.) Wurde die Technologie von lokalen Gruppen in größerem Maßstab angewandt und imitiert oder wurde sie nur von kleinen fremden Gruppen, z.B. vor Ort präsenten Römern, ausgeführt oder betrieben?

2.) Wurde die Technologie weiterverbreitet oder blieb sie ein einmaliges Phänomen?

3.) Wurde die neue Technologie dazu benutzt, lokal oder regional vorhandene Einrichtungen oder Geräte zu verändern oder zu verbessern, das heißt wurde sie in lokale Praktiken integriert oder war sie ein isolierter Fremdkörper?

4.) Können wir eine Verschiebung oder Modifikation in der Anwendung der Technologie feststellen? Können wir auf eine aktive und produktive Beschäftigung von Indigenen mit der Technologie schließen oder wurde sie nur passiv rezipiert?

Als besonderer Fall: Können wir eine Verschiebung oder Modifikation in der Organisation der Technologie feststellen?

5.) Wurden lokal oder regional verfügbare Produkte oder Rohstoffe für die Anwendung verwendet oder wurde die Technologie als fremdes Fertigprodukt implantiert?

6.) Wurde die neue Technologie lange genutzt oder war sie ein kurzfristiges Phänomen?

Die Beantwortung dieser Fragen im Rahmen unserer Fallstudien hilft, die appropriateness, die Angemessenheit der übernommenen Technologien für die empfangenden Gesellschaften zu evaluieren, auch wenn natürlich nicht immer eine definitive Antwort auf die Fragen möglich ist.

88 z. B. Michael Brian Schiffer, "Studying Technological Change: a Behavioral Perspective," World Archaeology 36 (2004), 579-585, vor allem 582; Wiebe E. Bijker, "How is Technology Made? - That is the Question!," Cambridge Journal of Economics 34 (2010), 63-76, besonders 72 . 
Die Übersichtstabelle (Abb. 7.1) macht die Bandbreite deutlich, wie die Antworten auf die Fragen zu kombinieren sind, und zeigt, dass Technologietransfer ein vielgestaltiger Prozess ist. Als sehr gute Beispiele für appropriate technology, für angemessene Technologie, können der Gewichtswebstuhl und die Drehmühle im Fezzan gesehen werden, da sie lange im Gebrauch waren, für sie lokale Rohstoffe genutzt wurden, sie innerhalb des Fezzan häufig auftreten und sie nachhaltig das Weben und Mahlen in der gesamten Region veränderten. Auf der anderen Seite der Skala liegen Technologien, die am besten als Hochtechnologie bezeichnet werden können. Beispiele hierfür sind die Нypokaustheizungen und Badeanlagen im pannonischen Limesvorland und im Fezzan, die nicht adaptiert werden und ein isoliertes Phänomen bleiben. Die Technik ist im Falle des Bades von Bratislava-Dúbrovka so fremd, dass sie nur ganz oberflächlich imitiert wird und eine Badeattrappe entsteht. Ein ähnlich isoliertes Phänomen ist die Töpferwerkstatt in Haarhausen, für die vor allem die sehr kurze Lebensdauer bezeichnend ist. Deutlich ist jedoch zwischen den mit der Töpferei verbundenen verschiedenen Einzeltechniken - Bau von Töpferöfen, Verwendung der Drehscheibe und Brennen der Gefäße - zu unterscheiden, da nach Aufgabe des Produktionsortes Haarhausen zumindest die Töpferscheibe im Gebrauch bleibt. Wichtig ist auch, dass vor Ort vorhandenes Material, nämlich Ton, verwendet wurde und die Brenntechnik insofern den lokalen Gegebenheiten angepasst wurde, als anstelle einer oxydierenden eine reduzierende Atmosphäre beim Brand hergestellt wurde, so dass die Färbung der Endprodukte sich deutlich von römischen Erzeugnissen unterschied. Zumindest partiell wurde somit in Teilbereichen die an sich römische Technologie adaptiert. Die Befunde in Haarhausen sind durch die neueren Untersuchungen zur Töpferscheibenkeramik in Mainfranken zu ergänzen, soweit es Gefäßherstellung betrifft. Von besonderer Bedeutung sind die modifizierten Reibschalen, da sie Hinweise liefern, dass nicht nur entweder in römischer oder in germanischer Tradition produziert wurde - und dies ohne gegenseitige Beeinflussung -, sondern dass auch die so typisch römischen mortaria Veränderungen unterworfen werden, also eine lokale Adaption vorgenommen wird ${ }^{89}$. Dass auch relativ komplizierte technische Vorgänge nicht immer als

89 Dies ist natürlich - wie insgesamt die Verwendung von mortaria - kein Beleg für eine ,Romanisierung', so jedoch Dietwulf Baatz, „Reibschale und Romanisierung," Acta Rei Cretariae Romanae Fautores 17/18 (1977), 147-148; Sigrid Dušek, „Römische Reibschalen im germanischen Thüringen," Alt-Thüringen 24 (1989), 183-198; Dušek, Haarhausen, S. 144-146; Morten Hegewisch, "Germanische Adaptionen römischer Importgefäße," Bericht der Römisch-Germanischen Kommission 86 (2005), 302-310. Anders zu Recht: Steidl, „Drehscheibenkeramik“, S. 87f. 110. 


\begin{tabular}{|c|l|l|l|l|l|l|}
\hline & $\begin{array}{l}\text { indigene } \\
\text { Anwendung }\end{array}$ & Weiterverbreitung & $\begin{array}{l}\text { Integration in } \\
\text { indigene Technik }\end{array}$ & $\begin{array}{l}\text { Modifikation der } \\
\text { fremden Technik }\end{array}$ & $\begin{array}{l}\text { Verwendung lokaler } \\
\text { Produkte/Rohstoffe }\end{array}$ & Dauer \\
\hline Cifér-Pác: Heizung & & & & & & \\
\hline Cifér-Pác: Häuser & & & & & & \\
\hline Dúbravka: Bad & & & & & & \\
\hline Haarhausen: Ofen & & & & & & \\
\hline Haarhausen: Brand & & & & & & \\
\hline Haarhausen: Geẩße & & & & & & \\
\hline EBleben: Gefäße & & & & & & \\
\hline Brilon: Blei & & & & & & \\
\hline Fezzan: Bad & & & & & & \\
\hline Fezzan: Webstuhl & & & & & & \\
\hline Fezzan: Mühle & & & & & & \\
\hline Jericho: Bad & & & & & & \\
\hline Jericho: Latrine & & & & & & \\
\hline
\end{tabular}

ABBILDUNG 7.1 Übersicht zu Modalitäten des Techniktransfers nach dem entwickelten Fragenkatalog.

high technology bezeichnet werden müssen, ist am besten an der germanischen Bleiverhüttung im Sauerland zu erkennen.

\subsubsection{Conceptual Transfer - Complete Transfer}

Eine weitere Kategorisierung des Transferprozesses ermöglicht das Aufgreifen eines Begriffspaars, das den Transport thematisiert: Die Unterscheidung zwischen complete transfer (kompletter Transfer) und conceptual transfer (konzeptueller Transfer) wurde von Rafael Frankel für Studien zur antiken Technikgeschichte im Kontext von Weinpressen im heutigen Israel etabliert ${ }^{90}$. Kompletter Transfer bezeichnet die Implementierung von Technologien, die im Vergleich zum Herkunftsland nicht verändert wurden. Im Kontrast dazu meint konzeptueller Transfer die Übernahme einer Technik bzw. eines technischen Vorgangs ohne gleichzeitiger Festlegung auf die materielle Umsetzung, so dass Veränderungen in Form, Größe oder Material bei der Herstellung von Geräten und Anlagen, um das technische Konzept zu realisieren und zum Funktionieren zu bringen, möglich und dementsprechend häufig sind. Beispiele für konzeptuellen Transfer unter den betrachteten Fallstudien sind die Drehmühle und der Gewichtswebstuhl, da hier nur das Konzept - Mahlen

90 Rafael Frankel, „Ancient Technologies: Complete vs. Conceptual Transfer“, Tel Aviv 39 (2012), $115^{-126 .}$ 
von Getreide durch einen drehenden Stein bzw. Spannen der Kettfäden durch Gewichte - vorgegeben war, während die materielle Umsetzung, um das Konzept zum Funktionieren zu bringen, nicht vorgegeben war. Die Varianz in der Realisierung einer Technologie kann auch bei der Umsetzung komplizierterer Vorgehensweisen, z.B. beim Herstellen von Blei, relativ groß sein, während Techniken wie die Heizung durch Erwärmen der Luft unter dem Fußboden nur einen relativ geringen Spielraum lässt, der jedoch auch ausgeschöpft wird, so wie in Jericho lokal anstehender Stein und nicht Ziegel für die Stützpfeiler verwendet wurde.

\subsubsection{Practical Technology - Prestige Technology}

Ein weiterer entscheidender Punkt für den Transfer ist das technologische Gefälle. Die technologischen Rahmenbedingungen (frames) zwischen Ursprungsgesellschaft und Zielgesellschaft müssen weitgehend übereinstimmen ${ }^{91}$. Dies ist insbesondere für das Imperium Romanum und viele seiner Nachbarn von Bedeutung, da zwischen ihnen die Unterschiede im zivilisatorischen Entwicklungsstand sehr groß waren.

Sehr große Kontraste im Verständnis und in der Anwendung von Technik erschweren den Transfer und verhindern insbesondere die Übernahme von zu komplizierter oder aufwändiger Technologie. So war die Adaption der römischen Drehmühle im Fezzan nur möglich, weil der technologische Abstand zwischen diesem Typ und der Reibmühle relativ gering war. Man bewegte sich somit im selben Rahmen. Hätte man dagegen eine Anlage mit mehreren hintereinander gestaffelten Wassermühlen wie in Barbegal in der Provence in den Fezzan transferiert, so hätte diese Technologie nicht in dem Maße adaptiert werden können, weil vielleicht die natürlichen Voraussetzungen nicht vorhanden waren, aber sicher, weil die Wassermühle eine ganz andere Komplexitätsstufe repräsentiert ${ }^{92}$. Trotzdem kommt natürlich ein solcher kompletter Transfer von weit entwickelten Technologien vor, wie die Töpferwerkstatt in Haarhausen oder die Anlagen in der Slowakei beweisen. In der Moderne wird dieses Verfahren vor allem aus ökonomischen Gründen praktiziert: Hochentwickelte Fabriken mit ganz spezifischen Fertigungstechniken werden beispielsweise in Ländern der so genannten Dritten Welt errichtet,

91 Zum Begriff des technological frame: Hans K. Klein, Daniel Lee Kleinman, "The Social Construction of Technology: Structural Considerations," Science, Technology \& Human Values 27 (2002), 40.

92 Zu Barbegal: Pierre Leveau, "The Barbegal Water Mill in its Environment. Archaeology and the Economic and Social History of Antiquity," Journal of Roman Archaeology 9 (1996), 137-153. 
weil entweder lokale Rohstoffressourcen ausgebeutet werden sollen oder die niedrigeren Fertigungskosten einen entsprechenden Anreiz bieten. Dies trifft jedoch für die römischen Beispiele nicht zu: Die Töpfereien in Haarhausen oder Eßleben/Frankenwinheim wurden nicht installiert, um billiger für das Imperium zu produzieren. Ein relativ moderner Grund für die Gründung von Haarhausen wurde zwar von der Ausgräberin Sigrid Dušek genannt, nämlich das Erschließen neuer Absatzmärkte, doch sind nicht-ökonomische Aspekte entscheidender, nämlich Technologietransfer zur Repräsentation ${ }^{93}$. Diesem Aspekt kann durch eine weitere terminologische Unterscheidung Rechnung getragen werden, so dass - in Anlehnung an den Titel eines wichtigen Aufsatzes zur Technikgeschichte - von praktischen bzw. Prestige-Techniken gesprochen wird ${ }^{94}$. Grundsätzlich war der Zugang zu und die Verwendung von römischer Technik außerhalb des Imperium Romanum nicht neutral, sondern sozial bedeutungsvoll. Viele der Fallstudien sind mit lokalen Potentaten zu verbinden, wie die Latrine und das Badehaus in Jericho mit Herodes dem Großen. Auch die aufwändigen Gebäude in Cifér-Pác und Bratislava-Dúbrovka wurden wohl im Auftrag von Angehörigen der einheimischen Elite errichtet, um den eigenen sozialen Status sowohl zum Ausdruck zu bringen als auch zu erhöhen. Gleiches ist für das Bad im Kontext der aufwändigen Stadthäuser von Gerama im Fezzan anzunehmen. Ebenfalls ist für die Töpferei von Haarhausen eine soziale Funktion anzunehmen, wobei die Gefäße nicht so sehr für eigene repräsentative Zwecke benutzt wurden, sondern eher um Verbindungen innerhalb eines begrenzten Raumes materiell greifbar zu machen und auch zu verstärken. Selbst für die Bleiverarbeitung in Westfalen ist eine Kontrolle durch einen lokalen Potentaten denkbar, wie dies von Michael Erdrich vermutungsweise vorgeschlagen wurde ${ }^{95}$. Transfer römischer Technologie über die Grenzen hinaus ist also nicht nur Ausdruck der Beziehungen zwischen provinzialen und indigenen Gesellschaften, sondern kann auch innerhalb dieser Gruppen wichtige soziale Funktionen erfüllen.

93 Dušek, Haarhausen, S. 132-148.

94 Brian Hayden, "Practical and Prestige Technologies: The Evolution of Material Systems," Journal of Archaeological Method and Theory 5 (1998), 1-55. Der Status erhöhende Effekt wird konkret benannt bei einem weiteren Beispiel von Technologietransfer: Birgit Arrhenius, „Die Schraube als Statussymbol. Zum Technologietransfer zwischen Römer und Germanen," in Frankfurter Beiträge zur Mittelalterarchäologie II. Schriften des Frankfurter Museums für Vor- und Frühgeschichte 12 (Frankfurt 1990) S. 9-26.

95 Michael Erdrich, „Rezension zu Walter Melzer - Torsten Capelle (Hrsg.), Bleibergbau und Bleiverarbeitung während der römischen Kaiserzeit im rechtsrheinischen Barbaricum,“ Germania 87 (2009), 629. 


\section{$4 \quad$ Schluss}

Technologietransfer jenseits der Grenzen des Imperium Romanum war ein geläufiges und vor allem ein vielfältiges Phänomen. Gemäß der Science and Technology Studies sollten Technologien als Artefakte betrachtet werden, so dass sie in Relation zu anderen Artefakten, die aus dem Imperium Romanum in das Gebiet jenseits der Grenze gebracht wurden, gesetzt werden können. Bei diesem Vorgehen bietet der Transfer von Technologien als komplexen Artefakten Analysemöglichkeiten, die beim so genannten römischen Import in das Barbaricum nicht immer gegeben sind. So lassen sich Techniken und die damit verbundenen Gerätschaften und Strukturen viel besser hinsichtlich ihres Gebrauchs ansprechen, so dass auch genauer zu beurteilen ist, wie stark sie verändert oder angepasst wurden ${ }^{96}$. Wie bei den Fallbeispielen gezeigt können Abstufungen in der Akzeptanz, unterschiedliche Formen der Adaption und Kriterien für die Übernahme identifiziert werden, so dass dadurch viel besser gefasst werden kann, wie Kulturkontakte genauer abliefen.

96 Vgl. hierzu das Modell für den Lebenszyklus (use life) von römischen Importen: Fraser Hunter, „The Lives of Roman Objects beyond the Frontier," in Wells, Rome beyond its Frontiers, S. 15-23 mit Abb. 1. 


\title{
Perceptions from Beyond: Some Observations on Non-Roman Assessments of the Roman Empire from the Great Eastern Trade Routes
}

\author{
Anne Kolb and Michael A. Speidel
}

Centuries of continuous warfare and successful expansion turned the Roman Empire into the single dominant power in the Mediterranean basin. Yet, although Roman warfare never fully came to an end, the countryside and the two to three thousand cities of the Empire in Italy and the provinces experienced many uninterrupted decades of peaceful prosperity from the beginning of the imperial era onwards. This prosperous Roman world, the orbis Romanus, owed much of its success to an extensive network of communication lines by land and sea, through which it was interconnected and accessible. The development of the imperial transport and communication infrastructure reflects both the pragmatic and systematic approaches of the Romans: Building on existing local lines of communication, the Romans took over, expanded or constructed new roads in the deployment zones and in the countries they had conquered. Thereby, they systematically and consistently linked newly acquired territory with the center. In a next step following the establishment of peace-especially under the Empire-, Roman building programs improved and further expanded traffic connections in the subjected areas incorporated into the road network in order to penetrate the territory of the empire. All elements of this network by land and sea made up an estimated length of around 500.000 kilometers. ${ }^{1}$

Nevertheless, even today this network is often thought of as a closed system, covering only the Roman world. But that was clearly not the case. Travel and commerce were by no means hindered by the confines of the Roman

1 See recently Anne Kolb, "The conception and practice of Roman rule: the example of transport infrastructure," Geographia Antiqua 20/21 (2011/12), 53-69 and A. Kolb, "Erfassung und Vermessung der Welt bei den Römern," in Vermessung der Oikumene, ed. Michael Rathmann and Klaus Geuss (Berlin, 2013) 107-118. A slightly augmented version of this paper will be published in the Chinese Journal of Ancient Civilizations, vol. 30 (2016). 
the empire. Even the great military barriers in Britain, on the German frontier and in North Africa were permeable. Roman traffic ways connected to lines of communication into territories well beyond the empire. In most cases, these routes had been in use for centuries before the Roman conquest. They led by land or sea to the north, south or east, and ultimately connected the Mediterranean with the countries on the North and Baltic Seas, Sub-Saharan Africa, Central Asia, India and China. Since the conquests of Alexander the Great and the 'discovery' of the Monsoon winds in the second century CE, trade relations between the Mediterranean world and the countries of the Far East intensified, ${ }^{2}$ and India and China were firmly integrated into the Western concept of the inhabited world, the 'oikumene'.

The famous medieval copy of an illustrated imperial Roman 'road map' (itinerarium) known as the 'Tabula Peutingeriana' with its depiction of the entire Roman road system from Britannia to the east provides a graphic illustration of this notion. For it shows how, in the east, the network of Roman roads seamlessly continues into non-Roman territories. Moreover, the last sheet of this remarkable document includes, for instance, references to Sera Maior (presumably China), the Ganges river ( $f$ l. Ganges), and the well known ancient seaport of Muziris with its templ(um) Augusti on the Malabar coast in south west India. ${ }^{3}$ The 'Tabula Peutingeriana' therefore displays a network of

2 See e.g. Raphaela Drexhage, Untersuchungen zum römischen Osthandel (Bonn, 1988). Gary Keith Young, Rome's Eastern Trade. International commerce and imperial policy, ${ }^{1} B C-A D$ 305 (London, 2001). Kai Ruffing, "Wege in den Osten: Die Routen des römischen Ost- und Südhandels (1.-2. Jh.)," in Zu Wasser und zu Land. Verkehrswege in der antiken Welt, ed. E. Olshausen and H. Sonnabend, Stuttgarter Kolloquium zur Historischen Geographie des Altertums 7 (Stuttgart, 2002), 360-378. Steven E. Sidebotham, Berenike and the ancient maritime spice route (Berkeley, 2011). Michael A. Speidel, "Wars, Trade and Treaties. New, revised, and neglected sources for political, diplomatic, and military aspects of imperial Rome's relations with India and the Red Sea basin, from Augustus to Diocletian," in 'Imperial Rome, Indian Ocean Regions and Muziris: Recent Researches and New Perspectives on Maritime trade, Proceedings of the international Seminar held at Irinjalakuda, Kerala, India 8-12 September 2013, ed. K.S. Mathew (New Dehli, 2015), 83-128.

3 Tab. Peut. 11,5. For Muziris see also Plin., NH 6,26,104. Periplus Maris Erythraei (= PME) 57. Ptol., Geogr. 4,5,14-15. Lukian, Quomodo historia conscripta sit, 31. For the templum Augusti see Michael A. Speidel, "Der Augustustempel bei Musiris. Zur Tabula Peutingeriana und zum Kaiserkult ausserhalb des Reiches”, in: 'Kaiserkult in den Provinzen des Römischen Reiches Organisation, Kommunikation und Repräsentation', ed. Anne Kolb and Marco Vitale (forthcoming). SB XVIII 13167 (2. cent. CE): Hermann Harrauer and Pieter Johannes Sijpesteijn, "Ein neues Dokument zu Roms Indienhandel, P.Vindob. G 40822," AAWW 122 (195), 124-155. For connectivity in the ancient world see Peregrine Horden and Nicholas Purcell, The Corrupting Sea: A Study of Mediterranean History (Oxford, 2000). 
routes that linked the Atlantic to the Indian and the Pacific oceans during the Roman imperial period and betrays the comprehensive global connectivity of the ancient world.

A few major trading routes into Asia, Arabia, India and China deserve to be singled out for the purposes of this paper. The so-called 'Silk Road' or 'Silk Routes' (not an ancient term) consisted of an entire network of trading routes that linked the Mediterranean and China by land and sea. ${ }^{4}$ Herodotus already mentioned the northern route connecting the Black Sea with Central Asia. ${ }^{5}$ It led via the Caucasus and the Caspian Sea to the Oxus river (Amu Darya) and from there via modern Afghanistan towards India and China. The 'Scythian gold', among other things, might have been brought to the West via this route. The southern route started at Syrian Antioch and led via Palmyra, the Parthian empire and Samarkand to Kashgar where it split into a northern and southern branch leading around the Tarim Basin and the Taklamakan desert. The two branches re-united at the so-called "Jade-Gate" from where they led to Dunhuang and Xi'an. Ancient Chinese sources reveal the strategic importance that was attributed to this long distance trade route, for according to these texts, the Romans had always wanted to be in direct contact with the Chinese, but the Parthians, wishing to control the intercontinental silk trade, prevented them from doing so. ${ }^{6}$

The so-called 'Incense Route', again a term not for a single route but for an entire network of routes, connected the Mediterranean port of Gaza via Petra, the capital of the Nabataean kingdom, with the southern parts of the Arabian Peninsula and the Persian Gulf. From a Mediterranean perspective, the 'Incense Route' afforded the import of frankincense, myrrh, spices and other precious goods from South Arabia, India and East Africa. Control of the

4 See most recently John E. Hill, Through the Jade Gate to Rome. A Study of the Silk Routes during the Later Han Dynasty ist to 2nd Centuries CE. An Annotated Translation of the Chronicle on the 'Western Regions' in the Hou Hanshu (Charlestone, 2009). Liu Xinru, The Silk Road in the World History (Oxford, 2010). For an overview see also Marek Jan Olbrycht, "Die Geschichte der Seidenstraße in antiker Zeit," in Die Krim. Goldene Insel im Schwarzen Meer. Begleitbuch zur Ausstellung in Bonn (Darmstadt, 2013), 67-87.

5 Hdt. 4,11. 17-23. 101.

6 Hou Hanshu 12: cf. Hill, Jade Gate (see above, n. 4), p. 27 and Donald Daniel Leslie and Kenneth Herbert James Gardiner, The Roman Empire in Chinese Sources (Rome, 1996), p. 51. Wei Lüe 11: cf. John E. Hill, The Peoples of the West from the Weilüe 魏略 by Yu Huan 魚䅈: A Third Century Chinese Account Composed between 239 and 265 CE. Draft annotated English translation. http://depts.washington.edu/silkroad/texts/weilue/weilue.html (8. Jan. 2014). section 11 and Leslie and Gardiner, p. 70. Cf. also Friedrich Hirth, China and the Roman Orient (Shanghai and Hongkong, 1885), p. 42. 
northern end of the caravan routes turned the Nabateans into middlemen in this trade, and made them rich. The Roman provincialisation of their kingdom in the year $106 \mathrm{CE}$ by the emperor Trajan, not only led to a new distribution of wealth and power in the region, but it also entailed the establishment of new institutions and infrastructure that facilitated the further development of long distance trade, including measures to increase security on land and sea and the construction of a direct road from Damascus via Bosra and Philadelphia to Aila on the Gulf of Aqaba. ${ }^{7}$

The 'discovery' of the monsoon winds in the second century BCE marked the beginning of a sea-borne long distance trade that established new and upgraded existing links between the Mediterranean and the countries on the Red Sea and Indian Ocean. Initially, this put the Ptolemies in the lucrative position of middlemen (thereby fuelling their rivalry with the Nabateans). Sea routes eventually linked the Ptolemaic and Roman harbors on the Red Sea with the South Arabian kingdoms, East Africa, India and Sri Lanka, Vietnam and China. The Ptolemies (and later the Romans) fostered this commerce by constructing ports, developing routes and, most important, by aiming to establish security along the coasts of the Red Sea. The Roman takeover of the Ptolemaic kingdom of Egypt in 30 BCE sparked a major increase in economic activities on the Red Sea and the sea routes to India. It also led to high revenues for the Roman treasuries from taxing the Indo-Mediterranean trade, as well as to diplomatic contacts with rulers of far away countries. ${ }^{8}$

To be sure, the connectivity of the Mediterranean basin with other parts of the ancient world neither depended on the existence of Roman roads nor on that of the Roman Empire. This is clearly borne out, for instance, by Ashoka's thirteenth 'Rock Edict' from Kandahar from around 250 BCE, which refers to embassies that the Indian Maurya king sent to the Hellenistic courts of Antiochos II Theos, Ptolemy II Philadelphos, Antigonos Gonatas, Magas of Cyrene and Alexander II of Epirus (?). ${ }^{9}$ Yet Strabo's claim that traffic between Egypt and India increased six-fold as a nearly immediate consequence of the Roman takeover of the former Ptolemaic kingdom of Egypt illustrates

7 Cf. Speidel, "Wars, trade, and treaties" (see above, n. 2).

8 Ibid.

9 Ulrich Schneider, Die großen Felsen-Edikte Asokas: kritische Ausgabe, Übersetzung und Analyse der Texte (Wiesbaden, 1978): Edict 13. See also Reinhold Merkelbach and Josef Stauber, Jenseits des Euphrat. Griechische Inschriften (München, 2005), p. 33 with further literature on p. 35. Cf. also Reinhold Merkelbach, "Wer war der Alexandros zu dem Ašoka eine Gesandtschaft geschickt hat?," EA $3^{2}$ (2000), pp. 126-128. For Hellenistic kings sending ambassadors to India see also Strabo 2,1,9.15,1,36. Plin., $N H$ 6,21,58. 
the enormous extent to which all aspects of international exchange appear to have increased in the wake of the establishment of the principate and the extension of Roman rule by Augustus and his successors. ${ }^{10}$ Lively descriptions of the effects of this increased global connectivity on people and communities have survived, for instance by Dio Chrysostomus for Alexandria or by Aelius Aristides for Rome." Dio Chrysostomos even held that the influx of Greeks, Italians, Syrians, Libyans, Cilicians, Ethiopians, Arabs, Bactrians, Scythians, Persians and Indians into Alexandria made them all a 'kindred people'

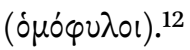

In spite of increased mobility and traffic since the late first century BCE, the effects of intercultural contacts evidently cannot be expected to have produced uniform transcultural knowledge and largely identical perceptions of the Roman Empire along the great eastern trade routes. Instead, we should expect local perceptions of the Roman Empire as a foreign power to have varied greatly according to time and place. It is no doubt mainly due to the great linguistic and methodological difficulties that such issues have not, so far, attracted much scholarly attention. Yet recent years have witnessed the publication of important and pertinent ancient texts with translations and commentaries by scholars from several different disciplines of ancient world studies. Few of these sources are generally known among students of ancient Mediterranean history, and some of these texts call for interpretations by historians of the Roman Empire. It seems apposite, therefore, to mention and comment on some of the most significant non-Roman assessments of the Roman Empire along the great Eastern trade routes.

\section{2 \\ Friends and Enemies}

Among the most famous ancient assessments of the Romans by a foreigner contained in a non-Roman source from the imperial period are no doubt the rock-face reliefs and the trilingual inscription at Naqsh-e-Rustam that glorify the deeds of the Sassanid king Shapur I. ${ }^{13}$ As this monument celebrates the king's grand victories over Roman troops, his invasions into Roman territories, and his capture of the Roman emperor Valerian, it is not surprising that the Romans are portrayed as rightly defeated aggressors and as violators

\footnotetext{
10 Strabo 2,5,12. 17,1,13.

11 Dio Chrys., Or. $3^{2,36}$ and 39. Arist., or. Rom. 11-13.

12 Dio Chrys., Or. 32,36.

13 André Maricq, “Res Gestae Divi Saporis," Syria 35 (1958), pp. 245-26o.
} 
of international agreements. From the late second or early third century CE Edessa in northern Mesopotamia, two of the earliest Syriac literary texts contain statements that convey a similar sentiment: 'The Letter of Mara Bar Sarapion to his son' and the 'Book of the laws of the countries.' ${ }^{14}$ However, their historical background differs considerably from that of Shapur's inscription, as the authors of these texts were victims of Rome's expansion rather than victorious kings. Both Syriac texts probably date to the period between the later second and the early third century CE when Rome, in successive steps, invaded, occupied, and finally provincialized Northern Mesopotamia and its capital city Edessa on the Silk Road. 'The book of the Laws of the countries' refers to the Romans as an aggressive power that will not refrain 'from always conquering new territories', ${ }^{15}$ whereas 'The Letter of Mara Bar Sarapion', even describes the Romans as arrogant, violent, self-righteous, uncivilized and dishonest aggressors with questionable moral standards. Yet rather than being mere accusations against Roman aggression, these texts seem to be literary products by members of the former ruling elite that essentially advocated philosophic strategies of how to cope with a cruel fate that led to the loss of power, wealth and status in a period of political transition. ${ }^{16}$ In essence, they propose to leave power and wealth behind and to indulge in education (paideia) and philosophy, and thus, by taking the moral high ground, to reverse the makings of fate and to outclass the Roman conquerors.

14 'Mara Bar Sarapion': Annette Merz, David Rensberger, and Teun Tieleman, Letter to his son (Tübingen, forthcoming). See also Michael A. Speidel, "Making use of History beyond the Euphrates. Political views, cultural traditions, and historical contexts in the Syriac 'Letter of Mara Bar Sarapion,", The Letter of Mara bar Sarapion in Context. Proceedings of the Symposium Held at Utrecht University, 10-12 December 2009, ed. Annette Merz and Teun Tieleman (Leiden, 2012), pp. 11-41. 'Book of the Laws of Countries': Han J.W. Drijvers, The Book of the Laws of Countries. Dialogue on Fate of Bardaisan of Edessa, 2nd ed. with a new introduction by Jan Willem Drijvers (Piscataway, 2006).

15 Drijvers, Book, pp. 52-53: '... it (sc. 'Fate') does not prevent... the Romans from always conquering new territories.... Torsten Krannich and Peter Stein, "Das 'Buch der Gesetze der Länder' des Bardesanes von Edessa”, zAC 8 (2004), 203-229, esp., 225f. § 40: '... noch die Römer ständig andere Länder in Besitz zu nehmen..... Interestingly, Euseb., Praep.

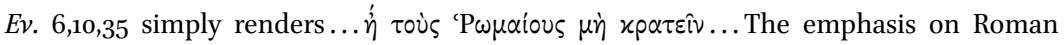
rule, rather than on continuous conquest is even more pronounced in the reworked ver-

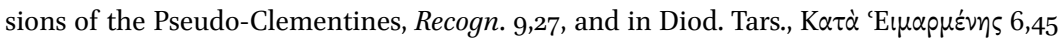
(for which see Illaria Ramelli, Bardaisan of Edessa: A Reassessment of the Evidence and a New Interpretation (Piscataway, 2009), 134-135). See also Drijvers, The Book, pp. 56-57: 'Recently the Romans have conquered Arabia...' (i.e. northern Mesopotamia). Krannich and Stein, "Das Buch", p. $227 \S 43$ : 'gestern (erst)'. Euseb., Praep. Ev. 6,10,41: $\chi \theta \dot{\varepsilon} \varsigma$. 
In this, the proposition of the Syriac texts, to some extent, appears to resemble that of the Pesher Habakkuk, a Hebrew text from the second half of the first century BCE preserved among the Dead Sea Scrolls. ${ }^{17}$ This interpretative commentary on the Book of Habakkuk repeatedly refers to the kittim, a term that is now practically universally taken to designate the Romans. Thus, written after Pompey's conquest of Jerusalem and the establishment of Roman supremacy over Judaea, the Pesher Habakkuk describes the kittim (modeled, of course, on the Chaldaeans of the Book of Habakkuk) as an evil and bellicose foreign power. They are said to be swift and formidable soldiers, inspiring all nations with fear, they wage wars to enrich themselves, they have conquered and pillaged many countries and, with their swords, mercilessly kill men, women, the old and children (even the unborn) alike. Collaborators and opportunists may become wealthy under this regime, but the Pesher predicts that from the hands of the kittim they will eventually suffer the same fate they inflict upon others. The text finally affirms that God will rescue those who maintain their faith and continue to live by his law, and that all others will suffer his retaliation on the Day of Judgement, thus (not unlike the Syriac texts mentioned above) predicting the ultimate victory of the righteous.

Further evidence comes from graffiti carved on rocks in an Ancient North Arabian dialect, Safaitic, by nomads from the eastern fringes of the Roman Empire in southern Syria, north-eastern Jordan, and northern Saudi Arabia. These Safaitic graffiti from between the first century BCE and the fourth century CE often provide vivid glimpses of the daily life of these nomads. They include some 30 inscriptions which mention either the author's relations with (or attitude towards) the $\mathrm{rm}$ (which, perhaps, not in all cases refers to the Romans') or which are dated to events involving the Romans or their emperor. ${ }^{18}$ In general, these inscriptions convey the impression not primarily 'of 'insiders' and 'outsiders', but of constant symbiosis and communication-as well as

17 1QpHab. For what follows see e.g. William H. Brownlee, The Midrash Pesher of Habakkuk (Ann Arbor, 1979). Moshe J. Bernstein, "Pesher Habakkuk," in Encyclopedia of the Dead Sea Scrolls (Oxford and New York, 200o), pp. 647-65o. Michael O. Wise, Martin G. Abegg Jr., and Edward M. Cook., The Dead Sea Scrolls: A New Translation. (San Francisco, 2005) pp. 83-86. Leonhard Burckhardt, "Rom und die Juden nach der Eroberung Palästinas durch Pompeius," DHA Suppl 9 (2013), pp. 59-76, esp. 70-74.

18 For what follows see M.C.A. Macdonald, 'Romans go home'? Rome and other 'outsiders' as viewed from the Syro-Arabian desert. In: J.H.F. Dijkstra and G. Fisher (eds.), Inside and Out. Interactions between Rome and the Peoples on the Arabian and Egyptian Frontiers in Late Antiquity. (Leuven, 2014), pp. 145-163. Cf. also Ulf Scharrer, "The problem of nomadic allies in the Roman Near East", in: M. Facella / T. Kaizer (eds.), Kingdoms and Principalities in the Roman Near East (Stuttgart, 2010), pp. 241-335, esp. 272-276. 
occasional conflict-between the nomads and the settled populations of the local kingdoms and Roman provinces of this region.19 ${ }^{19}$ Thus, there are texts that refer to 'the year [in which] Malichus king of Nabataea smote thirty centuries (?) of Roman soldiers', or to 'the year of the struggle between Rome and the Nabataeans', and to 'the year of the Nabataeans' rebellion against the Romans. ${ }^{20}$ None of these texts can be dated with any degree of certainty, yet some scholars have suggested they all belong to the period immediately following the Roman take-over of the Nabataean kingdom in $106 \mathrm{CE}$. While that cannot entirely be excluded, it is perhaps more (or at least just as) likely that (most of?) these inscriptions refer to hostilities between the Romans and the Nabataeans after Pompey's creation of provincia Syria in 63 в Се. One text refers to 'the year Caesar sent reinforcements to the province and put the province in good order.21 This graffito has been dated to the reign of Septimius Severus and, in any event, seems to convey an approving attitude of its nomadic author towards Roman rule in the region. The same seems to be true for the authors of another group of Safaïtic graffiti which refer to military service for Rome in units composed entirely from members of their tribes. Yet, there is also at least one episode of military brutality against a civilian on record, as well as some texts in which the authors say they were running away from the Romans or from Roman territory.

The authors of these Safaitic texts were likely thinking of Roman soldiers (irrespective of their origins) when they referred to 'the Romans'. The graffiti therefore probably refer to the relations of these nomads with the Roman army and authorities. It is hardly surprising that texts presenting Rome primarily as a military power originate from the fringes of the Empire where military action against the enemies of Roman order (as well as Roman soldiers' abuse of power) would evidently have occurred more often than elsewhere. Yet, as is well known, Rome also had staunch supporters in these regions on both sides of the Empire's provincial frontiers. Such friends of Rome did not hesitate to publically advertise their loyalty to Rome and to praise Roman victoriousness. An explicit example of this comes from the Hisma, a remote region in southeast Jordan through which the 'Incense Road' ran. It was here that a man named Laurikios carved a graffito in Greek language on a rock:22

\footnotetext{
19 Macdonald, Romans, p. 145.

$20 \quad$ Macdonald, Romans, p. 153 f.

21 Macdonald, Romans, p. 155.

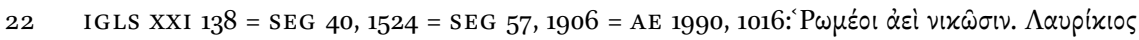
है $\gamma p \alpha \psi \alpha \chi \alpha i ̂ p \varepsilon Z \eta \dot{\eta} \nu \omega \nu$. The claim by Frédéric Alpi, "À propos d'une inscription grecque de la Hisma," Mélanges de l'Université Saint-Joseph LX 2007 (= Mélanges J.-P. Rey-Coquais)
} 


\section{The Romans always win. I, Laurikios wrote (this). Hail Zenon!}

Clearly, Laurikios rejoiced in Roman victoriousness, which in the context of this graffito most likely refers to local, small-scale engagements of the Roman army with brigands and other enemies of the Roman order in the region. ${ }^{23}$ Zenon might indeed, as has been suggested, be the same man mentioned in a nearby Nabataean graffito (from perhaps around the mid-second century $\mathrm{CE}$ ), in which he is described as a tribune (KLYRK $=\chi(\lambda i \alpha p X \eta \varsigma)$, and as the son of a man with an Arabic name (QYMT). ${ }^{24}$ If the term was used in its technical sense, Zenon, was an Arab commander of a milliary auxiliary unit of the Roman army who could read and write Nabataean, read and understand Greek, as well as,

(Beirut, 2007), pp. 335-353, esp. 343-344 that the inscription consists of two distinctly different graffiti is neither borne out by the photograph in his Fig. 2 on p. 337 nor by his drawing in Fig. 5 on p. 342, and therefore remains unconvincing. There is also no need to date the graffito to the 4 th -7 th c. CE based on late Roman and Byzantine 'Nika-Akklamations', as suggested by Alpi.

23 Thus also Scharrer, "The problem" (see above note 18), p. 276 with further bibliography. The alterity conveyed by Laurikios' use of the expression 'the Romans' is, by itself, not a reliable guide to whether or not he counted himself among the subjects of the Roman Empire: For Greek and early Syriac literature of the first centuries CE using the expression 'the Romans' to denote historical and contemporary representatives of the Roman state see Speidel, "Making use" (see above, n. 14), p. 15 and cf. p. 27 with n. 55. With particular reference to Roman soldiers in Late Roman and Byzantine literature: Alpi "À propos", pp. 349-350. For the Roman army fighting brigands along the trade routes as a possible context for this graffito see esp. SB 1,4282 = I. Pan du désert 87 and O. Krok. 87 from Egypt's eastern desert. Cf. Hélène Cuvigny, Ostraca de Krokodilô. La correspondance militaire et sa circulation (Cairo, 2005), p. 135.

24 William J. Jobling, "Aqaba-Ma'an Survey, Jan.-Feb. 1981," Annual of the Department of Antiquities of Jordan 26 (1982), pp. 199-209: šlm Zynwn br Qymt klyrk bb l'lm ('Greetings! Zenon son of QYMT, Tribune, for good, forever'). Cf. R. Godfrey Tanner, "Greek Epigraphy in South Jordan," ZPE 83 (1990), pp. 183-193, esp. 184-188. Benjamin Isaac, The Near East under Roman Rule. Selected Papers (Leiden, 1998), p. 341. For a different view: D. Graf, "The Nabataean Army and the cohortes Ulpiae Petraeorum," in E. Dąbrowa (ed.), The Roman and Byzantine Army in the East (Krakow, 1994), 265-305, esp. 282. Alpi, "À propos", esp. pp. 337, 339, and 347. The well-known bilingual (Greek-Nabataean) inscription from Ruwwafa in the Hejaz (AE 1977, 834 = SEG 39, 1390, cf. SEG 51, 2290) recording the dedication of a temple to the Emperors Marcus Aurelius and Lucius Verus in 166/169 CE is not, as often held, from beyond the frontiers of the Roman Empire, but from within provincia Arabia: Glen W. Bowersock, Roman Arabia (Cambridge, MA, 1983), pp. 156-157, now confirmed: Michael A. Speidel, Heer und Herrschaft im Römischen Reich der Hohen Kaiserzeit (Stuttgart, 2009), pp. 633-635. See also Michael C.A. Macdonald, Literacy and Identity in Pre-Islamic Arabia (Farnham, 2009), pp. 1-26. 
no doubt, some Latin. Yet whether or not both men were identical is perhaps less important in the present context than the message these short inscriptions permanently conveyed to passers-by. For the latter hardly just included Roman soldiers and members of local communities, but also any brigands in the area (or other enemies of the Roman order) as well as traders and caravans on the 'Incense Route'. They were all reminded of the Roman army's success at keeping up or restoring security in the region. No doubt, Zenon and his fellow members of the Roman army were all delighted to read messages of the kind Laurikios left behind.

However, not all foreigners thought of the Roman Empire in terms of a great military power. Ancient Chinese historiographical texts, for instance, have nothing at all to say about the Roman armed forces or their battlefield successes. These texts refer to the Roman Empire by the term 'Da Qin', Greater China, 'apparently thinking of it as a kind of counter-China at the other end of the world'. ${ }^{25}$ Although 'Da Qin' is described as a particularly large (and, by implication, powerful) state with many dependencies, there are no Chinese descriptions of Rome's army, military capacity or martialness. ${ }^{26}$ Rather, these texts simply praise the Romans as 'tall and honest.'. ${ }^{27}$

It is of course impossible to determine whether allied and dependent kings such as Tigranes III and Artavasdes III of Armenia, or Rhoemetalkes I of Thracia also cherished such idealistic concepts of Rome and her ruler when they added an image of Augustus to their coinage. ${ }^{28}$ Artavasdes III even included a legend claiming that Augustus was a benefactor (euergetes). Yet these kings owed their position to Augustus, and therefore their official appraisal of splendid relations with the Roman ruler was an entirely political statement. ${ }^{29}$ Moreover, like most of Rome's foreign friends, they lived within

25 Edwin G. Pulleyblank, "The Roman Empire as Known to Han China," JAos 119 (1999), pp. 71-79, esp. 71. Cf. also Krisztina Hoppál, "The Roman Empire According to the Ancient Chinese Sources," Acta Ant. Hung. 51 (2011), pp. 263-306, esp. 270. Yu Taishan, "China and the Ancient Mediterranean World. A Survey of Ancient Chinese Sources," Sino-Platonic Papers 242 (2013), pp. 1-268, esp. 28-29.

26 Cf. Leslie and Gardiner, The Roman Empire (see above, n. 6), p. 260.

27 Hou Hanshu 11: Hill, Jade Gate (see above, n. 4), p. 25.

28 Tigranes III and Artavasdes IV of Armenia: RPC I 3841. 3843. Anahit Mousheghian and Georges Depeyrot, Hellenistic and Roman Armenian Coinage (1 st c. BC-1st c. AD) (Wetteren, 1999), pp. 187-188 with table VIII, 169-170. IK 65, 472. Rhoemetalkes I of Thracia: RPC I 1708-1710.

29 For similar cases cf. e.g. Michael H. Crawford, Coinage and Money Under the Roman Republic: Italy and the Mediterranean Economy (Berkely, 1985), pp. 273-275. Fergus Millar, "Emperors, Kings, and Subjects: The Politics of Two-Level Sovereignty," in idem, 
the reach of Roman arms, and therefore may not always have felt entirely free to make their own political choices. For, as Eutropius $(8,8)$ ascertains, Rome's influence among her foreign allies rested as much upon veneration (veneratio) as on fear (terror). In any event, by including Augustus' portrait on their coinage they disseminated a symbol of loyalty to Rome, not a statement of their personnel assessment of Augustus or the Roman Empire.

It is therefore, perhaps, surprising to find the portrait of Augustus on a series of Sabaean coins from the Yemen. ${ }^{30}$ South Arabia is not usually counted among the regions that were under Roman control. Yet, the only plausible reason for Sabaeans to copy a portrait of Augustus (or any other Roman emperor) onto their coins seems to be that they too intended to send a signal of political loyalty to Rome in the same way that other allied kings and dynasts did in this period. ${ }^{31}$ Moreover, the Periplus maris Erythraei relates that the mid-first century 'legitimate ruler' ( $\varepsilon v \theta \varepsilon \sigma \mu \circ \varsigma \beta \alpha \sigma \lambda \lambda \varepsilon \dot{\varsigma} \varsigma)$ of the Sabaeans and the Himyarites,

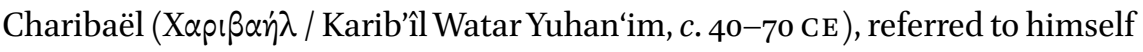

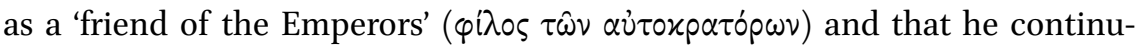
ously sent 'embassies and gifts' to the Romans. ${ }^{32}$ If this choice of words indeed reflects official Roman terminology, as seems likely, it implies that the kings of Saba and Dhu Raydan (= Himyar) had entered a state of political friendship (amicitia, cf. below) with Rome and were now among Rome's dependent allies. Further documentary evidence can be shown to corroborate this interpretation. Surely, Sabaean and Himyarite amicitia with Rome was, at least initially, the result of a military expedition, which the Roman general Aelius Gallus led to Southern Arabia in 26 / 25 BCE. Yet this alliance no doubt significantly contributed towards increased security along the maritime and terrestrial trade

Government, Society, and Culture in the Roman Empire, vol. II. (Chapel Hill, 2004), pp. 229-245.

30 Coins: BMC Arabia 32-48. Daniel T. Potts, "Augustus, Aelius Gallus and the Periplus: A Re-Interpretation of the Coinage of Șan'â' Class B," in Arabia Felix: Beiträge zur Sprache und Kultur des vorislamischen Arabien, Festschrift Walter W. Müller zum 6o. Geburtstag, ed. N. Nebes (Wiesbaden, 1994) 1-12, confidently identifying the portrait as that of Augustus on pp. 214-215. Stuart Munro-Hay, Coinage of Arabia Felix. The Pre-Islamic Coinage of the Yemen (Milano, 2003), 47-48. Martin Huth, Coinage of the Caravan Kingdoms-Ancient Arabian Coins from the Collection of Martin Huth. Ancient coins in North American collections, 10 (New York, 2010), xx-xxi and 100-101 ('Roman style bust', 'resembling bust of Augustus').

Cf. above n. 24 and 25 as well as e.g. the coins of Ajax, highpriest and toparch of eastern Cilicia Tracheia (RPC I 3724. 3726. 3727) or Philip, tetrarch of Gaulanitis (RPC I 4938-43). $P M E$ 23. For embassies from Southern Arabia to Rome see also Plin., $N H$ 12,31,56. 
routes in the wider region, thus facilitating trade and increasing its volume, which soon benefitted both sides. ${ }^{33}$

If public displays of the attitudes of foreign rulers and dynasts towards Rome were closely monitored and interpreted within the framework of transnational political communication, ordinary citizens from communities beyond the empire's boundaries, it seems, enjoyed a little more freedom in proclaiming their personal political opinion of Rome in their everyday lives. That, at any rate, is what Dio Chrysostomos implies in an episode from the Greek colony of Olbia on the northern shore of the Black Sea, where he passed through during the later first century CE. ${ }^{34} \mathrm{He}$ described the inhabitants of this colony that was situated on an important salt road as a community of long-bearded, backward Greeks, whose dialect was incomprehensible but whose beards would have thrilled a philosopher. Only one citizen of this colony, Dio claims, was clean shaven-out of flattery to the Romans. In the eyes of his Olbian fellow citizens such behavior was disgraceful and unseemly for real men. The episode may be greatly exaggerated or distorted, but Dio apparently expected his audience to believe it. Yet outward appearance and dress was of course not always intended to convey political statements. Thus, such motives were hardly foremost on the minds of the many people from the southern Red Sea and around the 'Horn of Africa' who are reported to have bought (and surely also wore) imported 'Roman' style clothes. ${ }^{35}$

\section{Trade and Friendship}

Nor were all political statements by foreign rulers concerning Rome motivated by anxiety. Thus, fear of Rome's military power can hardly have motivated Kujula Kadphises (ca. 30-8o CE), the first Kushan ruler, to strike the bust of a Julio-Claudian emperor on the obvers of a series of coins he minted at Taxila (near modern Islamabad in Pakistan). ${ }^{36}$ Even more surprisingly, the revers side

33 The argument is set out in full in Speidel, "Wars, Trade, and Treaties" (see above, n. 2). For a discussion of the evidence see also Michael A. Speidel, 'Almaqah in Rom?, ZPE 194 (2015) 241-258. Cf. also below.

34 Dio Chrys., Or. 36,17. Cf. e.g. David Braund, "Greeks and Barbarians: The Black Sea Region and Hellenism under the Early Empire," The Early Roman Empire in the East, ed. Susan Alcock (Oxford, 1997), pp. 121-136, esp. 126-129.

35 PME 6. 8-10.12-13.

36 John Marshall, Taxila. 3 vols. (Cambridge, 1951), vol. 2, p. 544. Rafique A. Jairazbhoy, Foreign Influence in Ancient India (Bombay, 1963), p. 120. David MacDowall, "Numismatic Evidence for the date of Kanişka," in Papers on the date of Kanişka, London, 20-22 April 
of these coins shows the Kushan ruler in Indo-Scythian dress sitting on what remarkably looks like a sella curulis. As seats of this type are not known to have belonged to the contemporary domestic culture of northern India, it is generally held that this image refers to a real Roman sella curulis. If correct, it might have been given to one of the numerous Indian missions on record that came to Rome seeking amicitia, for giving presents to successful such embassies is a well-documented Roman practice, and there are a number of known cases where the Roman grant of amicitia was underpinned by presenting a sella curulis (and other gifts) to the new amicus. ${ }^{37}$ Incidentally, what appear to be the actual remains of such a sella curulis have been unearthed during excavations at Taxila where the above-mentioned coins are believed to have been struck. ${ }^{38}$

If correct, the historical context of these coins is probably connected to diplomatic contacts with Rome. ${ }^{39}$ Augustus proudly records in his 'Achievements' that 'embassies of kings from India were often sent to me, such as previously have never been seen in the presence of any Roman leader. ${ }^{40}$ The immediate

1960, ed. A.L. Basham (Leiden, 1968), pp. 34-149, esp. 144 n. 4. Karl-Uwe Mahler, “Augustus und Kujula Kadphises, Herrscher der Kuschan," in Augustus—Der Blick von Aussen. Die Wahrnehmung des Kaisers in den Provinzen und in den Nachbarstaaten, D. Kreikbom et al. ed., (Wiesbaden, 2008), pp. 297-319, esp. 301-303.

37 David Braund, Rome and the Friendly King. The Character of the Client Kingship (London, 1984), pp. 34-35.

38 Marshall, Taxila, vol. 2, p. 544 no. 54 and vol. 3, p. 170 no. 54 .

39 For diplomatic contacts between Rome and India in the first century CE (with the references) see e.g. Gabriele Ziethen, "Legationes Externae in der frührömischen Kaiserzeit:

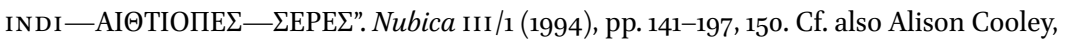
Res Gestae Divi Augusti. Text, Translation, and Commentary (Cambridge, 2009), 249-251 and Raoul McLaughlin, Rome and the Distant East. Trade Routes to the Ancient Lands of Arabia, India, and China (London, 2010), pp. 111-120. Later references in the sources include Dio 68,15,1 (106 CE), an ancient South Arabian inscription: Joëlle Beaucamp, Françoise Briquel-Chatonnet, and Christian J. Robin, "La persécution des chrétiens de Nagrān et la chronologie himyarite," Aram 11-12 (1999-2000), pp. 15-83, esp. 70 (ca. 218/19 CE?). HA Aurel. 33,4 (270 CE). Euseb., v.Const. 4,50 (336/7 CE). Amm. 22,7,10 (361 CE). Malalas 477 (530 CE).

$40 \quad \operatorname{RgdA}$ 31. See also Suet., Aug. 21,3. In particular: Oros., 6,21,19-20. Dio 54,9,8. Strabo 15,1,4. Plin., $N H 8,25,65$. As only two Indian embassies are independently known to have met Augustus, Cooley, Res Gestae, pp. 249-250 concludes that the Roman ruler unduly exaggerated diplomatic contacts with India in order to propagate the idea that his influence won friends from Rome even in the remotest parts of the Ancient World. Yet even though there can be no doubt that Augustus made the most of the arrival of Indian embassies, that by itself is not a compelling reason to question his statement all together, or to 
textual context of this statement within the res gestae implies that the Indian ambassadors came to ask for 'friendship' (amicitia) with Augustus and Rome, and that is indeed what Suetonius explicitly states. ${ }^{41} \mathrm{In}$ fact, whenever ancient reports of embassies from India provide any context or purpose at all, the envoys are always presented as seeking 'friendship' (amicitia, $\varphi$ i $\lambda i \alpha)$ with Rome. Surely, foreign envoys hardly travelled all the way to meet the Roman ruler simply to exchange empty politenesses. Unfortunately, the term amicitia by itself is no guide to the specific type or terms of a treaty (formal or informal), ${ }^{42}$ and the Roman narrative sources need not be comprehensive in this respect, as they are almost exclusively concerned with the political and military aspects of treaties. Suetonius held that foreign embassies from far-away countries sought Augustus's (and the Roman people's) friendship because of the renown of the Roman ruler's bravery and moderation. At least in some parts of the ancient Middle East reports of the vast and unparalleled powers of the Roman

believe that the other surviving sources reveal the entirety or even the majority of diplomatic contacts between India and Rome in the Augustan period.

$\operatorname{RgdA} 31$ continues by evoking envoys of the Bastarnae, Scythians, Sarmatians, Albanians, and Hiberians, and immediately begins with nostram amicitiam appetiverunt ..., implying that this statement, which linked the two sentences, was also true for the Indian envoys. Suet., Aug. 21: qua virtutis moderationisque fama Indos etiam ac Scythos auditu modo cognitos pellexit ad amicitiam suam populique Romani ultro per legatos petendam. For a recent assessment of the notion of amicitia with respect to Roman empire-building see Paul J. Burton, Friendship and Empire: Roman Diplomacy and Imperialism in the Middle Republic (353-146 BC) (Cambridge, 2001). For the importance of political amicitia for the Indo-Mediterranean trade in the imperial period see Michael A. Speidel, "Fernhandel und Freundschaft. Zu Formen römischer Wirtschaftsförderung am Roten Meer und am Indischen Ozean," (Orbis Terrarum 14, forthcoming).

42 For discussions of the correlation between amicitia and formal treaties see e.g. Alfred Heuss, Amicitia. Untersuchungen zu den rechtlichen Grundlagen der römischen Außenpolitik(Gräfenhainichen, 1933), esp. 55. Dieter Timpe, "Rechtsformen der römischen Aussenpolitik," Chiron 2 (1972), pp. 277-295, esp. 288. Christof Schuler, "Ein Vertrag zwischen Rom und den Lykiern aus Tyberissos," in: Griechische Epigraphik in Lykien. Eine Zwischenbilanz, ed. C. Schuler(Wien, 2007), pp. 51-79, esp. 64-65. Altay Coşkun, "Rückkehr zum Vertragscharakter der amicitia? Zu einer alt-neuen Forschungskontroverse," in Freundschaft und Gefolgschaft in den auswärtigen Beziehungen der Römer (2. Jahrhundert v. Chr.-1. Jahrhundert n. Chr., ed. A. Coşkun (Frankfurt a.M., 2008), pp. 209-230. Peter Kehne, "Feinde und Partner Roms," in Kontaktzone Lahn. Studien zum Kulturkontakt zwischen Römern und germanischen Stämmen, ed. Kai Ruffing, Armin Becker, and Gabriele Rasbach (Wiesbaden, 2010), pp. 31-65, esp. 42-43. Andreas Zack, "Forschungen über die rechtlichen Grundlagen der römischen Außenbeziehungen während der Republik bis zum Beginn des Prinzipats," Teil I-III, GFA 14-16 (2011-2013), pp. 47-119, 61-128, 63-113. 
emperors indeed seem to have left a deep impression with local dynasts. ${ }^{43}$ That, at any rate, is what the use of the title Kaisar by the Kushan ruler Kanishka II (ca. $225^{-245} \mathrm{CE}$ ) appears to imply. ${ }^{44}$ Whether, as has often been assumed, the name Gesar of the hero of Tibet's classic epic derived from the Latin imperial title Caesar is perhaps less than certain. ${ }^{45}$

Surely, for amicitia to exist or to be recognized as a state of international 'friendship' beyond the reach of Roman arms, it needed to satisfy certain expectations on both sides, even if imperial Rome thought of itself as (and behaved like) the dominant power. John Thorley argued that Kushan wealth was based, to a significant extent, on trade with the Roman Empire. ${ }^{46}$ Unfortunately, our sources fail to explicitly clarify whether and to what extent the Indian embassies to Rome were commercially motivated. It is suggestive, therefore, that the arrival of the earliest embassies from India under Augustus coincided with an enormous increase in the volume of Indo-Mediterranean trade. ${ }^{47}$ Moreover, some of the better known treaties establishing or confirming amicitia with Rome may indicate, by analogy, that facilitating trade and increasing its volume was indeed among the intentions that led both Romans and Indians to conclude such agreements of friendship. Thus, the earliest treaties with Carthage (508/7 and 348?), which are generally held to be wholly economic in contents, and which according to Moses Finley were among the very few international trade agreements that Rome ever concluded began, according to Polybios, with the words: 'There shall be friendship $(\varphi i \lambda i \alpha)$ between the Romans (...) and the Carthaginians (...) on the following conditions:.....48

43 Suet., Aug. 21: qua virtutis moderationisque fama. The emperor Antoninus Pius is said to have had such unmatched prestige (auctoritas) among foreign nations (HA Ant. Pius 9,10) that they referred their controversies to him (Eutrop. 8,8) and that even the Indi, Bactri, and Hyrcani (Epit. de Caes. 15,4) sent embassies to Rome seeking his just decision (iustitia). Cf. also the text to n. 53 , below.

44 John Thorley, "The Roman Empire and the Kushans", G \& R 26 (1979), pp. 181-19o, esp. 185186. Hermann Kulke and Dietmar Rothermund, A History of India, 4th edition (Abingdon, 2004), p. 83. McLaughlin, Rome (see above, n. 35), pp. 128-131.

45 Cf. e.g. Stephan V. Beyer, The Classical Tibetan Language (New York, 1992), p. 140. Li Lianrong, "History and the Tibetan Epic Gesar," Oral Tradition 16 (2001), pp. 317-342. Kurtis R. Schaeffer, Matthew Kapstein, and Gray Tuttle, eds., Sources of Tibetan Tradition (New York, 2013), p. 309.

46 Thorley, "Roman Empire” (see above, n. 39), p. 189.

47 Strabo 2,5,12. 17,1,13.

48 Polyb., 3,22,4 and 3,24, 3-13. John Serrati, "Neptune's Altars: The Treaties between Rome and Carthage (509-226 B.C.)," CQ 56 (2006), pp. 113-34, esp. 113 and 120. Cf. Moses Finley, The Ancient Economy (Berkeley, 1973), p. 161. 
The evocation of amicitia in the opening passage of these Roman trade agreements strongly suggests that amicitia could indeed be seen to have entailed important economic implications from Rome's earliest history onwards. One such implication concerned piracy, which the early treaties with Carthage apparently aimed to reduce. ${ }^{49}$ The link between amicitia and the fight against piracy is also borne out by the lex de provinciis praetoriis of $100 \mathrm{BCE} .{ }^{50}$ For this text, which deals with the provincial organization of Cilicia and Macedonia, the suppression of piracy and the administration of newly conquered territories, relates how Roman magistrates could address letters to eastern kings who had friendship and alliance with Rome, instructing them not to support or tolerate piracy but to help the Romans provide safety according to justice and the laws.

A recently published bronze tablet inscribed with the text of a treaty between Rome and the commune of the Lycians from 46 вСЕ provides further insight. ${ }^{51}$ It begins by confirming the state of $\varphi\left(\lambda i \alpha\right.$ (= amicitia), ${ }^{52}$ which, as we know from another recently published epigraphic copy of an earlier treaty, already existed between the two partners. ${ }^{53}$ Among other things, the remaining parts of the treaty of 46 вСЕ contain regulations of substantial economic significance. Thus, the new treaty refers to the previous mutual promise of military support (which evidently included fighting pirates), and then adds a new clause that specifies the relationship between Rome and her free allies with regard to criminal and civil cases. By confirming and spelling out the Lycians' right to be tried for capital offences according to their own laws in their native country, this clause not only endorsed a privilege to their communality but it also contributed to the legal security of travellers and merchants (or at least it can be understood to have done so) for if a dispute arose, those involved could

49 See Walter Ameling, Karthago: Studien zu Militär, Staat und Gesellschaft (München, 1993), 130-140.

$5^{0}$ IK 41, no. 31. Michael H. Crawford et al. (eds.), Roman Statutes, vol. I (London, 1996), no. 12. Cf. Jean-Louis Ferrary, "Recherches sur la législation de Glaucia," MEFRA 89 (1977), pp. 619-66o.

AE 2005, 1487 = SEG 55, 1452 = Bull. Ép. 2006, 146. For what follows see the excellent commentary by Stephen Mitchell, "The Treaty between Rome and Lycia of 46 вС (MS 2070)," in Papyri Graecae Schøyen (P. Schøyen I), ed. R. Pintaudi (Florence, 2005), pp. 161-258. Cf. also Schuler, "Ein Vertrag” (see above, n. 40). Pierre Sanchez, "La convention judiciaire dans le traité conclu entre Rome et les Lyciens (P.Schøyen I 25)," Chiron 37 (2009), pp. 363-381. Georgy Kantor, "SEG LV 1452, ll. 32-43, and the Crime of plagium in the Late Republic," ZPE 184 (2013), pp. 219-224, all with further bibliography.

$5^{2}$ It also included symmachia and koinonia.

53 Earlier treaty: AE 2007, 1504 = SEG 56, 1664. Schuler, "Ein Vertrag” (see above, n. 40). 
now consult a highly official text which was on public display. The clauses of this treaty therefore reassured both partners with respect to the efforts they would undertake to establish a safe environment within their respective realms, and they helped to prevent conflicts that could develop out of diverging notions of justice or interpretations of legal concepts. Thus, even though the treaty of 46 вСE also contained a new clause, by which the Lycians acknowledged the superiority of the Roman Empire, ${ }^{54}$ it also intended to establish a general context that was favorable to the trade relations between both partners, and thereby also promoted Lycian interests.

Flourishing around the mid-second century CE, the Roman jurist Sextus Pomponius also reflected on the correlation between political amicitia and international legal security. Thus, a fragment of his writings, which survives in the Digests reads: 55

... if there is neither friendship (amicitia) nor hospitium, nor a formal treaty made for the purpose of friendship (foedus amicitiae causa) between a particular people and us, they are not exactly our enemies, but anything, which belongs to us and passes under their control becomes their property, and a free man of ours who is captured by them becomes their slave.

It is not necessary for our present purpose to explore the entire range of legal and historical implications of this passage. ${ }^{56}$ It is enough to retain that in the mid-second century an eminent Roman jurist correlated the physical and legal security of Roman merchants in a foreign country with the existence of political amicitia (or hospitium or foedus amicitiae causa) between Rome and that country. Surely, it is also significant that Pomponius presents this correlation

54 For the 'Majestätsklausel' see Eugen Täubler, Imperium Romanum. Studien zur Entwicklungsgeschichte des Römischen Reiches (Leipzig, 1913), p. 64. Polyb. 21,32. Livy 38,11. I. Knidos 33 .

55 Dig. 49,15,5,2 (Pomponius, libro 37 ad Quintum Mucium):... nam si cum gente aliqua neque amicitiam neque hospitium neque foedus amicitiae causa factum habemus, hi hostes quidem non sunt, quod autem ex nostro ad eos pervenit, illorum fit, et liber homo noster ab eis captus servus fit et eorum: idemque est, si ab illis ad nos aliquid perveniat....

$5^{6}$ See Andreas Zack, "Forschungen über die rechtlichen Grundlagen der römischen Außenbeziehungen während der Republik bis zum Beginn des Prinzipats, I. Teil: Fragen an Sextus Pomponius: Quellen- und sachkritische Untersuchungen zu Pomponius 37. lib. ad Muc. D. 49,15,5," GFA 14 (2011), pp. 47-119 with the full relevant bibliography. In Zack's view (ibid., p. 108), amicitia-treaties, in Roman legal terms, were irrelevant to the safety of Roman and other ancient merchants. 
not as a phenomenon of a distant past but rather as a reality of his own days. Roman governments concluding and amending a variety of treaties and agreements within a framework that carried the label amicitia can therefore be understood to have been an important and common Roman response to the needs of international long distance trade (though Rome no doubt always kept its own benefit foremost in mind).

Of course this is not to suggest that there could not be or was no trade without treaties or a state of amicitia. But the sources referred to above suggest that the existence of amicitia reassured merchants and long distance traders. ${ }^{57}$ By concluding agreements of political friendship, Indian and other foreign rulers might therefore have hoped to increase the flow of commercial traffic from the Roman Empire into their realms. One might imagine, for instance, that the icon of a templum Augusti on the Peutinger map or the assurance of an Indian embassy to the emperor Constantine that their countrymen paid homage to the Roman emperor (of whom they allegedly kept paintings and statues) were somehow connected to such amicitia agreements. ${ }^{58}$ Be that as it may, Roman merchants involved in the trade with partners at Muziris would surely have rejoiced at the sight of the symbol of a templum Augusti on any comparable display or description of southern India. For such symbols no doubt implied a friendly attitude of local rulers towards Roman merchants and may even have hinted at the existence of a resident community or the repeated and regular presence of people from the Roman Empire (both of which are referred to repeatedly in the classical Tamil literature from the first centuries CE). ${ }^{59}$ Amicitia with Rome should have obliged the local Indian rulers to protect Roman merchants from pirates (which both the Peutinger map and the elder Pliny recorded in the region of Muziris).${ }^{60}$ The Periplus Maris Erythraei, perhaps, refers to such a case, for it mentions a situation of post-war turmoil at the

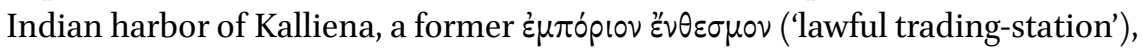

57 Compare Casson's remarks on hormoi apodedeigmenoi and emporion enthesmon in the Periplus Maris Erythraei: Lionel Casson, The Periplus Maris Erythraei. Text with introduction, translation, and commentary (Princeton NJ, 1989), pp. 271-277.

$5^{8}$ Euseb., v. Const. 4,50. For evidence of the imperial cult beyond the frontiers of the Imperium Romanum see Dieter Metzler, "Kaiserkult außerhalb der Reichsgrenzen und römischer Fernhandel," in Migratio et Commutatio. Studien zur alten Geschichte und deren Nachleben, ed. H.-J. Drexhage and J. Sünskes (St. Katharinen, 1989) 196-200, and Speidel, "Der Augustustempel" (see above, n. 3).

59 For western residents in Southern India see Pierre Meile, "Les Yavanas dans l'Inde tamoule," Journal Asiatique 323 (1940), pp. 85-123. Casson, The Periplus, pp. 24-25. MacLaughlin, Rome (see above, n. 35), pp. 18-19 and 55-56. 
and it informs its readers that Greek ships which by chance approached that harbor were escorted 'under guard' to the port of Barygaza. ${ }^{61}$

Evidently, the Indian Ocean was an area where the Romans had to achieve their political and economic goals by diplomacy and negotiation rather than by military superiority. Unfortunately, it is not known how many agreements of friendship between Rome and far away kings along the eastern trade routes existed at any given point in time. Nor is it possible to determine whether such monuments as the templum Augusti at Muziris or the Greek inscription on the statue base of a second or third century Roman emperor from the Himyarite capital of Zafar in modern Yemen, recently published by Christian Marek, are indeed products of political amicitia with Rome. ${ }^{62}$ However, the few cases that are on record imply that long distance trade could (and apparently often did) lead to the establishment of diplomatic contacts and political agreements, which the Romans called amicitia.

It thus appears that many rulers perceived agreements with Rome (or statements of mutual friendship) as an attractive means to facilitate trade. Of course, Roman emperors never hesitated to interpret, accept and promulgate requests by foreign rulers for amicitia as signs of submission, for in Roman eyes, accepting Roman domination was, of course, the ideal basis for political friendship. Also, at Rome, just as with the great empires of the Near and Far East, the influx of a great variety of exotic goods was understood to reflect the Empire's majesty. ${ }^{63}$ Conversely, it is not unlikely that Indian kings with good trade relations to Rome (and elsewhere) benefitted not only from the flow of trade as such but also from the symbolic value of popular foreign imports such as wine, coral or gold coins, simply by making them available to their subjects. ${ }^{64}$ Unfortunately, it is hardly ever possible to determine the precise symbolic value of any given product, which, in any event, would have varied depending on the recipient's location in society, space, and time. Nevertheless, the local value of imported goods directly reflected on the reputation of their country of origin as well as on the significance of their rulers. ${ }^{65}$ For when in $166 \mathrm{CE}$

$61 P M E$ 52. Cf. Casson, The Periplus, p. 215. MacLaughlin, Rome (see above, n. 35), p. 47. For a different view see Sunil Gupta, "Piracy and trade on the western coast of India," Azania 42 (2007), pp. 37-51, esp. 48-49.

62 Statue base: Christian Marek, "Zu neuen römischen Inschriften in Südarabien," Gymnasium 120 (2013), pp. 307-314.

63 Cf. e.g. Ov., Ars 3,113f. Tac., Ann. 2,6o. Arist., or. Rom. 12-13.

64 Sidebotham, Berenike (see above, n. 2), p. 251.

65 For a Roman assessment see Tac., Ann. 2,6o. For Sri Lanka: Plin., $N H$ 6,24,85 and Cosmas 11,338. For China: Hill, Jade Gate (see above, n. 4), p. 27. 
'envoys' of the Roman emperor Marcus Aurelius (or Antoninus Pius) arrived at the Chinese court with offers of rhinoceros horn, ivory, and turtle shell, the Chinese naturally took these gifts for tribute, but having expected jewels and exotica, they were not impressed and began to suspect that the wondrous accounts they had heard of the Roman Empire were all together exaggerated. ${ }^{66}$

4

\section{Phantasies and Information}

With the exception of very rare instances like the one just referred to, there are no sources that indicate or imply regular direct interaction between the two great empires at the opposite ends of the Eurasian continent during the first three centuries CE. ${ }^{67}$ Still, a good number of historical accounts from the Later Han period (23-220 CE) onwards clearly attest to the collection of detailed information, by the Chinese, on the Imperium Romanum. ${ }^{68}$ However, Chinese conceptions of 'Da Qin' (the term, by which early Chinese historiography referred to the Roman Empire) 'were confused from the outset with ancient mythological notions' of a utopian empire in the far west. ${ }^{69}$ Such notions were evidently at the very origins of the term 'Da Qin', for it meant 'Greater China' and was not a transcription of a foreign name. ${ }^{70}$ Moreover, the existence of a 'Greater China' at the opposite end of the world conflicted with the ancient Chinese conception of the real world, which held that China (the 'Middle Kingdom') was its cultural center. According to this conception, the farther away a foreign people lived from the center, the more 'barbarian' they were

66 Leslie and Gardiner, The Roman Empire (see above, n. 6), p. 223. Hill, Jade Gate (see above, n. 4), p. 27 and cf. $292-293$.

67 Cf. Leslie and Gardiner, The Roman Empire (see above, n. 6), pp. 100-101, and 158-60.

68 Collected in Hirt, China (see above, n. 6). Leslie and Gardiner, The Roman Empire (see above, n. 6). See also Hill, The Peoples (see above, n. 6) and Hill, Jade Gate (see above, n. 4).

69 David F. Graf, "The Roman East from the Chinese Perspective," AAS 42 (1992), p. 199-216, esp. 199-200. Pulleyblank, "The Roman Empire" (see above, n. 21), p. 78. Hoppál, "The Roman Empire” (see above, n. 21), p. 264. Yu, “China” (see above, n. 21), pp. 69-70.

70 Pulleyblank, "The Roman Empire" (see above, n. 21), p. 71 and 77. Hill, Jade Gate (see above, n. 4), pp. 254-256. Hoppál, "The Roman Empire" (see above, n. 21), pp. 269-271. Yu, "China” (see above, n. 21), pp. 1-43. Remarkably, the earliest Chinese texts with references to Rome contain no transcriptions based on the name Roma or Imperium Romanum: Pulleyblank, "The Roman Empire" (see above, n. 21), p. 77. 
believed to be. ${ }^{71}$ But of course it was unthinkable that the people of 'Greater China' should have been the most uncivilized people on earth. Therefore they were portrayed as resembling 'the people of the Middle Kingdom, and that is why this kingdom is called Da Qin'.72 The Romans were described as 'tall and virtuous like the Chinese, but they wear Western clothes.' An explanation was also provided: 'They [i.e. the Romans] say they originally came from China, but left it. ${ }^{73}$

Such fanciful notions were complemented with information derived from true facts. Ever since Friedrich Hirth, in 1885, published his monograph China and the Roman Orient with a selection of ancient Chinese texts containing information on the Roman and Byzantine Empires (including translations and an extended commentary), these records have attracted scholarly attention, though primarily among Sinologists. ${ }^{74}$ For these texts provide information on the routes to and the communication with the Roman Empire and other 'Western Regions', on its geography, its capital, its administration and infrastructure, on dependent kingdoms, on its agriculture and stockbreeding, on textiles, perfumes and herbs, on other natural resources as well as on the population and their daily life. Two texts in particular deserve to be mentioned, the Hou Hanshu and the Wei Lüe. The Hou Hanshu is the official history of the Later (or 'Eastern') Han Dynasty $\left(25^{-221} \mathrm{CE}\right) \cdot{ }^{75}$ It was compiled mainly by a man named Fan Ye in the first half of the fifth century CE from earlier works, to which important sections from a now lost work (Xu Hanshu) by Sima Biao $(240-306 \mathrm{CE})$ were added. These sections include a 'Chronicle on the Western Regions', which is primarily based on a report by Ban Yong to the emperor An

71 Cf. e.g. Herrlee G. Creel, Sinism. A Study of the Evolution of the Chinese World-View (Chicago, 1929). Q. Edward Wang, "History, Space, and Ethnicity: The Chinese Worldview," JWH 10 (1999), pp. 285-305.

72 Hou Hanshu 11: Hill, Jade Gate (see above, n. 4), p. 23.

73 Wei Lüe: Leslie and Gardiner, The Roman Empire (see above, n. 6), p. 7o. Hill, Jade Gate (see above, n. 4), p. 255.

74 Hirt, China (see above, n. 6). For bibliography see Leslie and Gardiner, The Roman Empire (see above, n. 6), pp. 3-6. Hill, Jade Gate (see above, n. 4), passim. Hoppál, "The Roman Empire" (see above, n. 21), pp. 266-269. Yu, "China" (see above, n. 21), pp. 43-127. For important remarks by an historian of the Roman Empire see Graf, "The Roman East" (see above, n. 64).

75 For what follows see Hill, Jade Gate (see above, n. 4), pp. xv-xxii with Burchard J. Mansvelt Beck, The Treatises of Later Han. Their Author, Sources, Contents and Place in Chinese Historiography (Leiden, 1990), p. 1, and Hans Bielenstein, The Restoration of the Han Dynasty, with Prolegomena on the Historiography of the Hou Han Shu (Stockholm, 1953), pp. 16-17. 
in c. $125 \mathrm{CE}$ and which replaced earlier accounts of the 'Western Regions.' ${ }^{76}$ This report included descriptions of the Roman Empire that stemmed from information the Chinese envoy Gan Ying had gathered during his mission to Da Qin. Although Gan Ying never actually reached the Imperium Romanum, he is said to have made it to the shores of the Persian Gulf in $97 \mathrm{CE}$, where he collected as much information on the Da Qin as he could. ${ }^{77}$ Other important sources of information may have resulted from the rare occasions of direct contact such as the Roman 'embassy' of $166 \mathrm{CE}$ which the Hou Hanshu records as having been sent from Āndūn, the king of Da Qin (i.e. Marcus Aurelius, or, perhaps, Antoninus Pius). ${ }^{78}$ The other early historiographical text containing important information on Da Qin, the Wei Lüe, is a chapter on 'Peoples of the West' from a now lost 'Brief Account of the Wei Dynasty', compiled at an unknown date in the third century CE by Yu Huan. ${ }^{79}$ The chapter has survived as an extensive quotation in a work of the fifth century. It both repeats earlier information on Da Qin (including much from the Hou Hanshu) and supplies valuable new material, which seems to date mainly to the second and early third century CE. ${ }^{80}$

Various problems are connected with the Chinese historical accounts and their interpretation. The compilation of these texts in ancient China was a bureaucratic procedure that involved much copying of earlier accounts and relied on records and archives. ${ }^{81}$ Thus, the precise origins and date of the underlying pieces of information and how they found their way to China often remains unknown, although diplomats, merchants and the great eastern trade

$7^{6}$ Hou Hanshu 1: Hill, Jade Gate (see above, n. 4), p. 13 and cf. p. 159.

77 On Gan Ying's mission and his much debated itinerary see Hou Hanshu 10: Hill, Jade Gate (see above, n. 4), pp. 23 and 481-483. Leslie and Gardiner, The Roman Empire (see above, n. 6), pp. 141-148. Hoppál, "The Roman Empire” (see above, n. 21), pp. 299-30o. Yu, "China” (see above, n. 21), pp. 5 and 10-17.

78 Hou Hanshu 12: Hill, Jade Gate (see above, n. 4), p. 27 and cf. 289-296.

79 See Édouard Chavannes, "Les pays d'Occident d'après le Wei lio," T'oung pao 6 (1905) pp. 519-571. Leslie and Gardiner, The Roman Empire (see above, n. 6), pp. 65-78. Hill, The Peoples (see above, n. 6), 'About the Text' and 'About the Dating and the Background of the Text'. Hoppál, “The Roman Empire” (see above, n. 21), pp. 268-269.

8o For other (later) ancient Chinese accounts relevant to the Roman Empire and the ancient Mediterranean World see Leslie and Gardiner, The Roman Empire (see above, n. 6), p. 3. 33. 57. 80. Cf. also Hoppál, "The Roman Empire” (see above, n. 21), pp. 268-269.

81 Cf. e.g. Leslie and Gardiner, The Roman Empire (see above, n. 6), pp. 19-31. Hoppál, "The Roman Empire" (see above, n. 21), p. 269 with further bibliography. 
routes undoubtedly played a fundamental role. ${ }^{82}$ The characterization of the Romans in the Hou Hanshu as 'honest in business: they do not have two prices' or the long list of 'products of Da Qin' in the Wei Lüe reflect the importance of long distance trade in transmitting information from the Mediterranean to China. ${ }^{83}$ A particularly complex issue concerns the identification of topographical and geographical features in the ancient Chinese accounts. The main difficulty is that the transcription of foreign place names from Chinese characters and the reconstruction of their phonological values in the Han period requires a highly specialized knowledge of Chinese historical phonology and, apparently, nevertheless often produces highly controversial results. ${ }^{84}$ Moreover, it is not usually taken into account that many places in the Roman East, in particular, had more than one name, and that the Chinese authors may have transcribed pronunciations of place names that (multiple) transmission by non-Greek and non-Latin speakers had significantly distorted.

The matter is clearly important if we want to understand and make use of these texts. The introduction to the chapter on the Roman Empire in the Hou Hanshu might serve as an illustration: 'The Kingdom of Da Qin is also called Lijian. As it is found to the west of the sea, it is also called the Kingdom of Haixi (= 'West of the Sea')'. ${ }^{85}$ Nearly the same statement was also included into the Wei Lüe. ${ }^{86}$ It is perhaps not entirely surprising that the legendary empire of 'Greater China', as a real state, also had other, less mythical names, which derived from existing political or geographical entities. However, there is no consensus, which countries or regions Líjiān and Haixi referred to, and it therefore even remains unclear what parts the term Da Qin exactly denoted. There are various competing theories concerning the derivation and location of

82 This aspect will be discussed in full in Anne Kolb and Michael A. Speidel, "Imperial Rome and China: Contacts and the Collection of Information," in Proceedings of the 22nd International Congress of historical Sciences, 23.-29. August 2015, Jinan, Shandong, China (Cambridge, forthcoming).

83 Hou Hanshu 12: Hill, Jade Gate (see above, n. 4), p. 27. Wie Lüe 12: Hill, The Peoples (see above, n. 6), section 12. For reports of contacts between China and the West (including Rome) from the second century CE onwards see e.g. Graf, "The Roman East" (see above, n. 64), p. 200. Leslie and Gardiner, The Roman Empire (see above, n. 6), pp. 150-162. Hill, Jade Gate (see above, n. 4), pp. 291-296.

84 On the matter in general see esp. Pulleyblank, "The Roman Empire" (see above, n. 21). Hill, Jade Gate (see above, n. 4), pp. xix-xx.

85 Hou Hanshu 11: Hill, Jade Gate (see above, n. 4), p. 23.

86 Wie Lüe 11: Hill, The Peoples (see above, n. 6), section 11: 'The kingdom of Da Qin is also called Lijian. It is west of Anxi (Parthia) and Tiaozhi, and West of the Great Sea'. Cf. also Leslie and Gardiner, The Roman Empire (see above, n. 6), p. 67. 
Lijian, including Hyrcania, Alexandria, Petra, Seleucia, Media, and Rai (ancient Teheran). ${ }^{87}$ Edwin Pulleyblank, a leading expert of Chinese historical phonology, maintained in his review of Donald D. Leslie's and Kenneth H.J. Gardiner's The Roman Empire in Chinese Sources that Lijian was the Han transcription for Hyrcania, the region on the southern shores of the Caspian Sea. ${ }^{88}$ In his opinion, however, the name Lijian was used in ancient Chinese records to refer to the former Seleucid Empire. Later, according to Pulleyblank, at some time after the absorption of the last (i.e. Syrian) remains of the Seleucid kingdom by the Roman Empire 'it was decided at the Han court that Dà Qín corresponded to Lijiān'. Considering that important strands of the over land silk routes led to Zeugma and to Antioch in the Roman provincia Syria, the association of Da Qin with a term for Syria would surely be fitting. ${ }^{89}$ Recently, John E. Hill also maintained that Lijian was a term that referred to former Seleucid territory. ${ }^{90}$ Rather disconcertingly, however, and contrary to Pulleyblank's lengthy argument (which Hill does not refer to in this matter), he claimed that the term Lijian derived from the Greek name of the Seleucid Empire. Notwithstanding, Yu Taishan argued even more recently that Lijian (or Lixuan) referred to the Ptolemaic kingdom of Egypt, whereas John E. Hill (unknown, it seems, to Yu Taishan) rather more convincingly suggested that the term Haixi referred to Egypt. ${ }^{91}$ Consequently, the equation of Da Qin, Lijian and Haixi, as well as other attempts to identify place names in the sections of the ancient Chinese records on Da Qin, has led to a confusing and still ongoing debate, ${ }^{92}$ in which, however, the number of options under discussion does not appear to have

$87 \quad$ Hill, Jade Gate (see above, n. 4), p. 256.

88 Pulleyblank, "The Roman Empire" (see above, n. 21), pp. 73-75. Graf, "The Roman East" (see above, n. 64), p. 203 assumed that 'T'iao-chih is simply an attempt to transcribe the word "Tigris"'. According to Pulleyblank ibid., Tiáozhī was the transcription of Seleukeia, and both (Wū)Chísăn and Zésăn that of Alexandria. Yu, "China” (see above, n. 21), p. 25 (without taking note of Pulleyblank's contribution) argues that Lixuan (i.e. Líjiān) is a contracted transcription of [A]lexan[dria]. Hill, The Peoples, section 15 equates Zésăn with Azania on the coast of East Africa, and Leslie and Gardiner, The Roman Empire (see above, n. 6), pp. 190-191. identify Zésăn with Cyprus.

89 Cf. only the itinerary described in the 'Parthian Stations' of Isidore of Charax: FGH $781=$ Duane W. Roller, "Isidoros of Charax (781)," in Brill's New Jacoby, ed. I. Worthington, Brill Online, December 2013, <http://referenceworks.brillonline.com/entries/brill-s-newjacoby/isidoros-of-charax-781-a781>781 F2.

$90 \quad$ Hill, Jade Gate (see above, n. 4), pp. 256-257 with further bibliography.

91 Yu, "China" (see above, n. 21), pp. 5 and 41-42. Hill, Jade Gate (see above, n. 4), pp. 251-254. Hoppál, "The Roman Empire" (see above, n. 21) refrains from identifying Lijian or Haixi. 
changed much since those established by Friedrich Hirth and his immediate successors. Essentially, the proposed solutions for the meaning of 'Da Qin' are the Roman Empire as a whole, the eastern regions of the Empire (as already suggested by Friedrich Hirth), particularly Syria and Egypt, or, depending on the context of the narrative, either Roman territory or the Imperium Romanum as a whole..$^{93}$

So much confusion and so many contradictory interpretations by specialists of the relevant fields of Sinology might discourage scholars of the ancient Mediterranean world to make use of the ancient Chinese accounts of the far West. Yet there is, perhaps, an approach that could lead to more reliable results. For it seems that what ever the terms Lijian and Haixi may have referred to, they were not fully synonymous with Da Qin but rather designated parts or aspects of it. This is, for instance, implied by statements, recorded in the Hou Hanshu, maintaining that one comes 'into Haixi to reach Da Qin' or that 'in these territories ( $s c$. of Da Qin), there are many precious and marvelous things from Haixi, ${ }^{94}$ Another passage from a different chapter of the Hou Hanshu mentions a group of musicians and magicians in $121 \mathrm{CE}$ who claimed that they were from Haixi, which the Chinese who recorded it identified as Da Qin. ${ }^{95}$ Interestingly, the term Lijian does not recur in the sections on Da Qin of the Hou Hanshu or the Wei Lüe. Haixi is the only concrete geographical aspect of Da Qin these texts single out. It might seem reasonable, therefore, to follow John Hill's suggestion and think of Da Qin as referring to the Roman Empire at large, and Haixi to have been a part of it (perhaps Egypt?).

Other passages, however, seem to add to the confusion. For the Hou Hanshu, commenting on the government of Da Qin, records: 'Their kings are not permanent. They select and appoint the most worthy man. If there are unexpected calamities in the kingdom, such as frequent extraordinary winds or rains, he is unceremoniously rejected and replaced. The one who has been dismissed quietly accepts his demotion, and is not angry'. ${ }^{66}$ The equivalent passage in

93 Leslie and Gardiner, The Roman Empire (see above, n. 6), pp. xxi-xxvi and 232. Hill, Jade Gate (see above, n. 4), pp. 254-256. Hoppál, "The Roman Empire" (see above, n. 21), pp. 269-271. Yu, "China" (see above, n. 21), pp. 1-42.

94 Hou Hanshu 12: Hill, Jade Gate (see above, n. 4), p. 27. Cf. Leslie and Gardiner, The Roman Empire (see above, n. 6), p. 52. Hou Hanshu 10: Hill, Jade Gate (see above, n. 4), p. 23. Cf. Leslie and Gardiner, The Roman Empire (see above, n. 6), p. 47.

95 Leslie and Gardiner, The Roman Empire (see above, n. 6), p. 42. Pulleyblank, "The Roman Empire" (see above, n. 21), p. 75. Hill, Jade Gate (see above, n. 4), p. 291. Cf. Hoppál, "The Roman Empire" (see above, n. 21), p. 270. Yu, "China" (see above, n. 21), p. 22.

96 Hou Hanshu 11: Hill, Jade Gate (see above, n. 4), p. 25. Cf. Leslie and Gardiner, The Roman Empire (see above, n. 6), p. 49 . 
the Wei Lüe reads: 'The ruler of this country is not permanent. When disasters result from unusual phenomena, they unceremoniously replace him, installing a virtuous man as king, and release the old king, who does not dare show resentment. ${ }^{97}$ This statement is alternatively thought to refer to the second century CE imperial practice of appointing a successor to the throne by adoption, the Adoptivkaisertum, or to refer to the Republican system of elected consuls, or to be nothing more than a fabulous story of an ideal country far-away ${ }^{98}$ However, other parts of the same passage suggest a completely different solution. In these, the king is said to have regularly left his palace to hear cases, and, according to the Hou Hanshu: 'a porter with a bag has the job of always following the royal carriage. When somebody wants to discuss something with the king, he throws a note into the bag. When the king returns to the palace, he opens the bag, examines the contents, and judges if the plaintiff is right or wrong.99 The parallel passage in the Wei Lüe reads: 'When the king goes out, he always orders a man to follow him holding a leather bag. Anyone who has something to say throws his or her petition into the bag. When he [i.e. the king] returns to the palace, he examines them and determines which are reasonable.100 The passages in both texts also contain references to governmental archives and to a group of counselors.

It is very tempting to understand these comments as referring to Roman provincial governors rather than to Roman emperors. For it is not difficult to recognize central aspects of a Roman governor's duties: his round trip through his province hearing cases, the well-known system of collecting petitions, preparing responses and making use of archives, as well as discussing matters of state with his consilium. Consequently, the former quote concerning the replacement of kings may perhaps not refer to true kings either, but again to Roman provincial governors. In all events, that would go well with the notion conveyed by the Chinese sources that the country had no permanent ruler but a system (though not entirely understood by the Chinese who recorded it) by which 'worthy' and 'virtuous' men were selected to replace their predecessors.

97 Wie Lüe 11: Hill, The Peoples (see above, n. 6), section 11. Cf. Leslie and Gardiner, The Roman Empire (see above, n. 6), p. 70.

98 Leslie and Gardiner, The Roman Empire (see above, n. 6), p. 49 n. 62 with further bibliography. Hill, The Peoples (see above, n. 6), notes 11.18. Yu, "China" (see above, n. 21), p. 619. Cf. also Hoppál, "The Roman Empire” (see above, n. 21), pp. 276-282 with unconvincing speculations on Rome and Syrian Antioch.

99 Hou Hanshu 11: Hill, Jade Gate (see above, n. 4), p. 25. Cf. Leslie and Gardiner, The Roman Empire (see above, n. 6), p. 48.

100 Wie Lüe 11: Hill, The Peoples (see above, n. 6), section 11. Cf. Leslie and Gardiner, The Roman Empire (see above, n. 6), p. 71. 
One might object that the Chinese texts explicitly refer to the 'king' of Da Qin, not to governors, and therefore seem to be concerned with the Empire at large and with its capital Rome. However, reports of the powers and splendors of Roman provincial governors, not least those of the praefectus Aegypti who resided in the palace of the former Ptolemaic kings and ruled the country in their stead (loco regum), might well have led commentators from the Far East to mistake such governors for local kings. Moreover, the Hou Hanshou and the Wei Luë claim that Da Qin had established several tens of minor 'dependent kingdoms', which might be understood as a reference to the Roman Empire's provinces. ${ }^{101}$ If correct, some details of Roman provincial administration must indeed have reached China during the first two centuries CE. However, we must presumably admit that Chinese knowledge of the Roman Empire (Da Qin) was defective and largely restricted to information from Egypt (Haixi?) and Rome's other eastern provinces.

Finally, some information included in the sections on Da Qin seems to have had Chinese rather than Roman origins. For at least in one instance it appears that cultural and administrative realities of the ancient Chinese Empire contaminated the historical accounts of the Roman Empire. Thus, knowledge of local Chinese institutions appears to have affected the short descriptions of the Roman imperial system of transport and communication. Both the Hou Hanshu and the Wei Lüe refer in surprising detail to the rest stops of this system, to the distances between them and to their appearance: 'At intervals they have established postal relays, which are all plastered and whitewashed... Each ten li $(4.2 \mathrm{~km})$ there is a postal stage, and each thirty $l i(12.5 \mathrm{~km})$ a postal station. ${ }^{102}$ The purpose of this Roman institution was also recorded by the Chinese: 'Relay stations were established in strategic positions allowing orders to travel quickly

101 Splendors: Tac., Hist. 1,11,1. Strabo 17,1,12. For a recent discussion and further bibliography cf. e.g. Andrea Jördens, Statthalterliche Verwaltung in der römischen Kaiserzeit. Studien zum praefectus Aegypti (Stuttgart, 2009) 11-15. Anne-Valérie Pont, "Rituels civiques (apantêsis et acclamations) et gouverneurs à l'époque romaine en Asie Mineure," in: Ritual Dynamics and Religious Change in the Roman Empire, ed. O. Hekster, S. Schmidt-Hofner, C. Witschel (Leiden, 2009), pp. 185-211. Dependent kingdoms (or provinces?): Hou Hanshu 11: Hill, Jade Gate (see above, n. 4), p. 23. Cf. Leslie and Gardiner, The Roman Empire (see above, n. 6), p. 47. Wei Luë 11 (the reference here is to dependent kings): Hill, The Peoples (see above, n. 6), section 11, and Leslie and Gardiner, The Roman Empire (see above, n. 6), p. 71. Hou Hanshu 11 and 12: Hill, Jade Gate (see above, n. 4), p. 26 and 27. Cf. Leslie and Gardiner, The Roman Empire (see above, n. 6), pp. 47 and 52. For the respective passage in the Wei Lüe (11) see Hill, The Peoples (see above, n. 6), section 11, and Leslie and Gardiner, The Roman Empire (see above, n. 6), p. 70. Cf. also Hoppál, "The Roman Empire" (see above, n. 21), p. 282. 
between the main postal stations at all seasons.'103 These statements have been understood to refer to the vehiculatio or cursus publicus of the Roman Empire, as it was indeed among the purposes of this Roman institution to transmit official communications quickly, and as the description of its infrastructure in the Chinese accounts appear to be accurate enough. ${ }^{104}$

However, distances of 10 li $(4.2 \mathrm{~km})$ between postal stages and thirty li (12.5 $\mathrm{km}$ ) between the larger postal stations are not confirmed by Roman sources. Although Roman itineraries do list small and large stopping places, they are recorded at intervals of 6-12 miles (c. 9-18 km) and 25 miles ( $37 \mathrm{~km})$, which correspond to around half a day's and a whole day's journey by foot respectively. That amounts to two or three times the distance indicated by the Chinese sources. ${ }^{105}$ In particular, the very short distances of $4.2 \mathrm{~km}$ were not in use in the Roman Empire. Perhaps there was confusion between postal stations and local inns, which probably lay at rather close intervals in the vicinity of cities. Yet, another perhaps more plausible solution might be that the Chinese authors' knowledge of their own postal system contaminated their account of Da Qin, for these texts insist that the Roman and Chinese postal systems were nearly identical: 'They have ... postal stations just as we have them in China'.106 It is particularly suggestive, therefore, that Chinese sources from the Qin Empire mention short distances of 2.6 miles between the postal stops, which precisely equals the distance of $10 \mathrm{li}(4.2 \mathrm{~km})$ as recorded in the Hou Hanshu and the Wei Lüe. ${ }^{107}$ The perceived identity of these important institutions both in China and in 'Greater China' (Da Qin / Rome) may therefore have encouraged the Chinese authors and compilers to insert additional "information".108 It is therefore perhaps not to be excluded that the ancient Chinese accounts of Da Qin contain more such supplemented information that originated from knowledge of Chinese institutions.

\footnotetext{
103 Hou Hanshu 28: Hill, Jade Gate (see above, n. 4), p. 55.

104 On the subject in general see Anne Kolb, Transport und Nachrichtentransfer im Römischen Reich, (Berlin, 2000).

105 Kolb, Transport, pp. 212-213.

106 Wei Lüe 11: Hill, The Peoples (see above, n. 6), section 11. Leslie and Gardiner, The Roman Empire (see above, n. 6), p. 70. See also Hirt, China (see above, n. 6), p. 44 (Chin-shu) and 70. Leslie and Gardiner, The Roman Empire (see above, n. 6), p. 81.

107 Chun-shu Chang, The Rise of the Chinese Empire, vol. 1 (Ann Arbor, 2007), p. 54, who also mentions intervals of 5,2 miles $(8.4 \mathrm{~km})$.

108 For the postal service of ancient China see Peter Olbricht, Das Postwesen in China unter der Mongolenherrschaft im 13. und 14. Jahrhundert (Wiesbaden, 1954), p. 36. Michael Loewe, The Government of the Qin and Han Empires 221 BCE-220 CE (Indianapolis, 2006), pp. 106-118.
} 
Perhaps the most significant notion that emerges from this admittedly very cursory overview of disparate evidence is the enormous geographical distribution of detailed information (however accurate) of the Roman Empire throughout the ancient world at large. ${ }^{109}$ Evidently, this was a consequence of global connectivity, long distance trade, and the impressive reputation of the Imperium Romanum and its rulers. However, making further use of the surviving evidence in most cases requires close collaboration between scholars of the Classical World and the respective specialists of other ancient civilizations. Such collaboration, we believe, promises rewarding results for all fields involved and would significantly contribute to the complex contemporary outside perception of the Roman Empire and its impact on the ancient world at large.

109 Cf. also the overview of relevant evidence in McLaughlin, Rome (see above, n. 35), pp. 16-21. 


\title{
Hospitium: Understanding 'Ours' and 'Theirs' on the Roman Frontier ${ }^{1}$
}

\author{
John Nicols
}

The assumption behind the practice of hospitium is that there are two parties to a relationship, and that the two parties do not belong to the same community [see below]. Crucial to the establishment of the relationship is that the parties exchange gifts and agree thereby also to respect and to protect the person and property of the 'other'. Implicitly, hospitium, by recognizing what is 'ours' and what is 'theirs' and by making a commitment to performing mutually beneficial services, could and indeed did promote peaceful exchange between 'strangers'. How this ritual worked in practice and how it evolved from the Late Republic into the Early Principate is the subject of this paper. Of course, this is not the complete story of hospitium, but rather an exploration of one dimension of the phenomenon. ${ }^{2}$

Hospitium, as a respected form of ritual, offers a compelling structure governing exchange between 'us' and 'them'. Moreover, during the Principate it became a vehicle for 'them' to become more like 'us' [Romans, i.e., 'to Romanize']. ${ }^{3}$ Hospitium could play this role because all Indo-European peoples (as best we can tell) shared the fundamentals of Guestfriendship / Gastfreundschaft; ${ }^{4}$

1 This article honors Lukas de Blois. I am grateful for his many displays of hospitium over many years.

2 A full discussion of hospitium is planned for a monograph on the subject. The latter is nearing completion.

3 In a number of sessions and volumes of Impact of Empire I have explored the theme of hospitium and exchange in Roman history and did so at recent sessions in Münster, Nijmegen and Durham, and now in New York.

4 'Guestfriendship' is somewhat awkward in English: Mommsen felt comfortable with Gastrecht / -freundschaft in his seminal study, "Das römische Gastrecht und die römische Clientele", in Römische Forschungen 1 (Berlin: Weidmann, 1864), 319-90. I prefer to use the Latin word, hospitium. Also: Bolchazy, L.J., Hospitality in Early Rome: Livy's concept of its humanizing force. Chicago: Ares Publishers, 1977. Balbín Chamorro, Paloma, Hospitalidady patronato en la Península Ibérica durante la Antigüedad. 2006. Nicols, J., "The Practice of hospitium on the Roman Frontier", Impact of Empire, 2010, and "Hospitality among the Romans, in The Oxford Handbook of Social Relations in the Roman World, ed. M. Peachin, Oxford, 2011, 
indeed, hospitium [both publicum and privatum] and its associated rituals and expectations have played a significant, if somewhat underappreciated, role in defining the relations between Romans and peregrines; in particular, hospitium provided a venue for peaceful and profitable interaction between the two parties in a world that did not enjoy the advantages of international law. The relationship / agreement may be characterized as one,

- that was extra-legal, indeed unenforceable,

- that assumes reciprocity, and a conscious awareness that the benefits and services exchanged, whether in material or services, were or ought to be of equal 'value',

- that the relationship was continuous, and over generations, and indeed,

- that it assumes protection of person and of property of the alien when in the community of his hospes / guestfriend, and

- that it served to enhance the reputation of each party and was celebrated / commemorated in a variety of ways by both parties. ${ }^{5}$

By the time of Augustus, peregrine communities in Iberia began to employ the Latin language, and Roman technical terms, to conclude pacts of hospitality even when no Roman was involved. Nonetheless, as will be argued here, we must also recognize that beneath the common vocabulary, each of the peregrine partners brought to the relationship expectations that were not consistent with what we know about Roman / Italian models. In brief, hospitium assumed not only that two parties were involved, but also that the institution was sufficiently flexible to allow for some considerable variation in its practice.

The argument is developed here in three steps. First, and precisely because hospitium involves exchanges between members of different communities, we need to consider the basics of 'ours and theirs', namely, how did Romans and peregrines understand where 'ours' begins and 'theirs' ends. The discussion then turns to the practice of hospitium, both in its public and private forms. The third step is not directly related to hospitium, but does offer context for understanding, by analogy, how Roman and peregrine variations of hospitium might be blended successfully.

422-435. Also: O. Hiltbrunner / D. Gorce: Art. "Gastfreundschaft" in Reallexikon für Antike und Christentum, viII (Stuttgart 1972), Sp. 1061-1123l. O. Hiltbrunner: Gastfreundschaft in der Antike und im frühen Christentumk, wвG (Wissenschaftliche Buchgesellschaft); Auflage: 1., Aufl. (1. April 2005).

5 These points have been made and documented in my other publications (see the Select Bibliography at the end), and need not be repeated here. 
To a member of the Roman elite of the Principate, there will have been no doubt about the meaning and implications of 'ours'. The departure point was clearly Mare Nostrum. Sallust, Caesar, Livy, Pliny Maior and Tacitus all stress nostrum in referencing the internal sea. ${ }^{6}$ So too were the fines imperii Romani well established in physical and in psychological space. ${ }^{7}$ Augustus [and conflating several passages from the Res Gestae, cc. 10, 12, 14, 26] had expanded [auxi] the borders of the empire, and had pacified [pacavi] what lay between them and the Mare Nostrum.

Moreover, as Claude Nicolet has demonstrated, Augustus and Agrippa prepared and posted maps that laid out, for all to see exactly, what might be 'ours' and what lay beyond. ${ }^{8}$ But the contours were not to be found solely on a map posted at Rome. The Atlantic to the West, the North Sea, and the axis of several northern rivers-Rhine, Neckar and Danube-became the effective borders of the Empire. Moreover, as the Roman system of defense became more static, the limes also served the same purpose, and both directly and indirectly helped to define where 'ours' ended and 'theirs' began.

There are problems with this perception. It is not only that the process took time, and evolved between the late Republic and Principate, but also there is good reason to believe, as I want to argue here, that the degree of homogeneity was anything but consistent. I often have wondered for example how a praefectus fabrum, or ancient quartermaster, faced with meeting the daily needs of a legion or cohort on the march, and in areas that were less Romanized, and perhaps less congenial, met his responsibilities. That is: how did the various citizen and peregrine communities along the roads view the soldiers marching through 'their' territory? Would the peregrine feel that the supplies of food and fodder made available to the marching cohorts had been provided willingly and at a fair price? Or did the supplies and quartering need to be extracted by force or intimidation, and taken from those who were perhaps not so willing? The issue is a particularly pointed one, for the meaning of hospitium in the later Roman Empire does change to include compulsory quartering of troops. ${ }^{9}$

6 Sall. BJ, 17f., Caes. BG 5.1; Liv 26.42; PlinMaior, $n h .6$ 142; Tac. Ag 24 .

7 That is, the 'frontier' here includes not only the actual borders of the Roman Empire, as at the Rhine or Danube, but also within a province and at the intersection of peregrine and Roman culture; for example, in interior and less urbanized parts of Tarraconensis or Lugdunensis.

8 Claude Nicolet, Space, Geography, and Politics in the Early Roman Empire, Ann Arbor (UMich Press 1994), 4-11.

9 Cod. Theod., 7.9; also Leonhard, Art., hospitium in RE 8.2, 2498. 
How to proceed? There are two complementary questions we can consider in respect to the practice of hospitium on the Roman frontier: How did Romans understand 'ours and theirs' as these concepts played out in their hospitable arrangements? And how did peregrines understand 'ours and theirs'? The first question is certainly easier to address than the second, and for that reason will be tackled first.

In the Republic, Mare Nostrum is mentioned by Livy, in reference to the Punic Wars and to the results of those conflicts. But fines are not so clear. Beginning early in Roman history, the Republic [so Cicero and Caesar below] justified going to war by the need to defend and protect our [nostri] amici, socii and hospites from enemies yet more dangerous [admittedly it is not always clear who these communities were]. Nonetheless, these three terms do describe classes of peoples who enjoyed a variety of relations, public and private, with the Roman state and with individual Romans. Admittedly there is much overlap in these three terms. Amici might be citizens; socii and hospites were not. Moreover, peregrines might first have been identified as hospites, and then latter, as relations evolved, became also socii and amici. Originally, hospites were outside or on the margin of the self-defined Roman sphere of influence; but certainly before the end of the Republic hospites / peregrines were to be found throughout Italy and the various Roman provinces. ${ }^{10}$

As Sallust indicates $(B C 6)$ Rome progressed by rendering aid to her socii and amici [sociis atque amiciis auxilia portabant]. Caesar writes in many places about the need to protect and to defend the socii and amici and hospites nostri in Gaul [see next paragraph]. Noteworthy here is, first, that nostri should be understood inclusively, to include communities [hospitium publicum] and individuals [hospitium privatum] and does not refer to space. Second, the categories mentioned are not mutually exclusive; there is no reason why an individual or a community could not be any one or all of the three at the same time. Hence, we may reasonably conclude that this emphasis reflects two perspectives, the first, as is well established, that Romans used such considerations [defending friends, allies and guest-friends] to justify going to war. For our purposes, however, the focus in the Republic was rather on the manner in

10 Note the case of Cornelius Balbus receiving hospitium in his hometown of Gades after become a Roman citizen and senator. 
which the decision was justified, namely, to defend communities and individuals ['our' allies and hospites] and not territory.

To return to our imaginary quartermaster: how would he work with peregrines? Here Caesar suggests a solution. Caesar selected Marcus Mettius to negotiate an arrangement with Ariovistus, because of the hospitium he enjoyed with the Gallic king [qui hospitio Ariovisti utebatur [BG 1, 47]. This solution is not an isolated example, for Caesar adopts and / or mentions how he used hospitium on other occasions in all his works [ $B C 2,25 ; B A 68, B H$ 16]. Consider the words of Diviciacus, 'those who enjoyed the hospitium and friendship of the Roman People were the most powerful men in Gaul' = populi Romani hospitio atque amicitia ... in Gallia potuissent, 1, 31; also at 5, 27, etc. I want to emphasize the implications these statements, for they are central to the argument of this paper, and especially when we turn to what peregrine hopites considered 'theirs'. Clearly, and to anticipate: peregrines [here Gauls] and Romans understood how hospitium [publicum and privatum] worked and were willing for the most part to take advantage of the benefits, so as to facilitate exchange of goods and services.

It is quite clear from the many references that hospitium provided the dynamic element in the social structure that allowed Romans and peregrines to interact in a constructive way. Tacitus concurs in many places throughout his works [e.g., Ger 20, e.g.], and notes inter alia especially how Valens and his soldiers, while on the march to Italy, abused the iura hospitii [ hist 3, 2 and 45]. That is, Valens made use of hospitium to provide for his soldiers, and did so in a manner that offended his hosts, namely, he and his legionaries seized goods that might have been offered by hospites voluntarily and demanded services for which there would be no reciprocation. They offended gods and men, just as Verres [hospitium ... quod sanctissimum est, Verr., 2.2.110] had done in violating the hospitium of the Sicilians, when he acted in a manner that was appropriate for a wild beast [fera atque immanis belua, Verr., 2,5.109]. ${ }^{11}$ It is clear that in practical, everyday matters involving Romans and peregrines, both parties employed an institution, here hospitium, and one that resonated within the unique culture of each. The particular significance of these passages is the following: hospitium provided a ritual and a portal that facilitated interpersonal exchanges when there were no other rules or laws to provide guidance. Moreover, and through these interpersonal connections, hospites were able to manage an orderly, or perhaps more orderly, and less-exploitative exchange of material goods, from 'us to them' and from 'them to us'. Even so, as the cases

11 On the significance see below; also J. Nicols, Civic Patronage in the Roman Empire, Leiden [Brill, 2015], Chapter 5 and especially $185^{-193 .}$ 
of Verres and Valens reveal, there was no guarantee that hospitium would be respected consistently, and no recourse to the courts if it was not.

By the end of the first century AD this narrative of 'ours and theirs' changed, and this change is easily documented in Tacitus. In the Agricola 8, Tacitus mentions that Britannia was a ferox provincia. Agricola first had to pacify the warring tribes; tribes that were outside the Roman jurisdiction and hospitium. Admittedly, Tacitus does not make a direct contrast between ferox and hospitium, but such a connection is implicit. In the Histories [4, 73-74], Cerialis warns the Treveri that, should the Romans withdraw, warrior bands would once again destroy civilization [= urban culture and peace]..$^{12}$ Indeed, the historian makes it very clear on two occasions in the Agricola [21 and 30] that 'ours' refers to areas within the Empire that enjoy peace, urbanization, culture, civilization; indeed specifically humanitas. ${ }^{13}$ Implicitly, these were places indeed where hospites and hospitium [quod sanctissimum est, so Cicero, see above] and other conventions were respected, and peaceful exchange could take place. Those who did not respect hospitium lived and acted like wild beasts and stood outside the self-defined humanitas of the Roman system. In this manner the concept of membership shifted: in the Republic, one did not need to be associated with the Roman Empire to enjoy the benefits of Roman hospitium. In the Principate, however, participation in the system was based on and defined by a sense of territory. Those within the Roman frontiers, individuals and communities, were eligible to enjoy the benefits of hospitium and to participate in this form of humanitas; those outside the frontiers were excluded from both.

Conclusions regarding the Roman concept:

1. In the Republican period, 'ours' relates to human beings, to communities and to individuals [amici, socii, hospites]; under the Principate, 'ours' becomes space / territory. Communities are less relevant. Hospitium plays an important role, albeit a changing one, but in both periods it serves to mediate the relationship between the two distinctive communities or individuals.

2. As Roman notions of what is 'ours' and what is 'theirs' evolve, so too does the practice of hospitium. Increasingly the latter does not describe the relationship between communities and individuals of different states,

\footnotetext{
12 On the use of nos in these chapters, see Holly Haynes, The History of Make-Believe: Tacitus on Imperial Rome, Berkeley and Los Angeles, (UCal Press; 2003) $163 \mathrm{ff}$.

13 Admittedly, there some cynicism in these passages, but the point is rather to understand how the Romans perceived their actions, see the next paragraph.
} 
but can now be employed to describe 'hospitable' relations between individual and groups who may be citizens or peregrines.

3. For the Romans of the Principate, 'ours' includes enjoying the advantages that are the goals of hospitium, namely the promotion of humanitas, urbanitas, and peace. 'Ours' includes the two groups:

a. hospites, both individuals and communities, who were to varying degrees integrated into the Roman system; who might also be amici, clientes, or socii.

b. hospites who were peregrines living on the 'frontier' whose only connection to Roman and to Romans was through hospitium.

4. The idea of 'theirs' includes those who were clearly outside this system; those who lived in places that the Romans considered to be ferox or individuals / communities who lived as wild beasts and did not respect or acknowledge hospitium at all; places that did not enjoy the benefits of Roman humanitas.

Here I acknowledge the work of my recently deceased colleague and friend Professor Jürgen Untermann [Cologne] who knows / knew the Keltic texts far better than I do, and I will therefore postpone discussing the purely Keltic texts in this context [though this will come in my fuller study of hospitium, mentioned above at note 2]. ${ }^{14}$ Instead, the paper now focuses on Kelts in transition from peregrine to Roman status and Latin culture; doing so allows us to get a sense of how hospitium might have evolved as Roman and peregrine cultures blended on the 'frontier.' ${ }^{15}$ In doing so we can gain some insights into the peregrine perspective by looking at texts that document how peregrines became more Roman, and yet retained significant features of their native cultures. In brief, we can try to identify enduring components [some may call them 'anomalies'] of 'theirs' as they become more like 'us'. There are two such components that I want to mention here. The first relates to the subject of this paper, namely, to the practice of hospitium, and the second to religious syncretism. In both cases, significant components of traditional culture persist despite the adoption of the Latin language and other Roman cultural forms. Note: I include the brief discussion of religious syncretism not because it has much to do with hospitium, but rather to provide an example of how Roman

14 Monumenta Linguarum Hispanicarum vols 1-4; Wiesbaden [Reichert; 1975-1998].

15 On the physical and psychological frontier, see above at note 5 . 
and peregrine cultures could blend at one level, and yet preserve distinctive characteristics at another level. For this is indeed what happens in the case of hospitium.

Regarding hospitium: There are dozens of tabulae and tesserae hospitalis from Spain, and most are dated [as here with the Tillegus text from Torre de Cabreira near Lugo in NW Spain, SE of Coruña]. This text and other images of the tabulae and tesserae are available at: <https://scholarsbank.uoregon.edu/ xmlui/handle/1794/13015>.

We can also follow the evolution in nomenclature and identify characteristic features that are similar to, but also occasionally radical departures from, conventional Roman usage. With Tillegus, the date of the agreement is clear, i.e., it is within one generation of the Augustan conquest. During that time, both parties to this agreement [to judge from their names] are peregrine Kelts [Tillegus himself and the Lougeii], but they opted to conclude the arrangement in Latin. Both parties are then on the road from 'them to us'. Moreover, the formulas employed are conventional for Roman tesserae hospitalis:... hospitium fecit and in fidem clientelamque are the exact words used at this time to record a similar agreement between a Roman quaestor pro praetore $[A E 1962,287=A E$ 1972,263 ] and the community of Munigua [between Sevilla and Cordoba]. So too is the placement of the names of the magistrates; and equally, the overall form of both tablets is nearly identical. Nonetheless, the text takes an unusual and surprising turn: it is the Lougeii, i.e., the peregrine community, who receive Tillegus and his dependents into their fides and clientela [...eumque uxorem liberosque ... in fidem clientelamque.... Castellanei... receperunt]. This oddity is not an accident. Another slightly earlier tabula indicates that the Lougeii did indeed know the proper language, for in $\mathrm{AD} 1$ they also made a pact of hospitium, and coopted Asinius Gallus as patron and did so in the standard manner. The reversal of roles, the group as the patron and the individual as the client, is significant and suggests, I believe, that we are dealing with a Keltic convention persisting in Roman dress. ${ }^{16}$

A third tabula [CIL 2.2633] provides another variant. Two indigenous communities [near Astorga] used the Latin language to renew hospitium vetustum antiquom [venerable and ancient] and to receive each other into their respective

16 There is another anomaly, though it is one that may been recognized elsewhere; namely hospitium assumes originally equality in the status of the two parties in each of their respective communities; clientela / patrocinium does not. This ambiguity however is well documented throughout the Roman West, so while it may not have any particular meaning here, it does illustrate that the peregrines understood and employed the common formulae. 
fidem clientelamque - a highly unusual arrangement [... eique omnes ali $(u) s$ alium ... receperunt], and unparalleled elsewhere in the Roman West. The significant hint here is that this text records the renewal of the ancient agreement that apparently had developed in a manner different from Roman norms. Here, then, we can say with some confidence that we are observing continuity of traditional forms in a society that is transitioning to a new language and culture. The original agreement belongs to the time when the respective clans were more 'theirs' than 'ours', but they have gone far in that the Latin language is used and Roman forms are now binding.

This conclusion may appear speculative, but there are examples of similar transitions in religious practices. When a clearly Keltic individual, Medamus, makes an offering to the Keltic god Bormanicus [CIL II 2402] and employs the Latin language and Roman style [altar] to do so, he is expressing his conviction that the efficacy of his offering is not diminished by the use of 'foreign' forms. Moreover, even men with names like C. Julius Hispanus, presumably a Romanized Kelt, continue to honor Lugubus Arquienolobus or Lahus Paraliomegus [Javier Gomez Vila, Epigrafia romana de la provincia de Lugo, No. 44; and IRdeL $5,67-68]$.

This pattern is confirmed by the aggregate data drawn from the traditional Callaecian areas:

TABLE 9.1 Frequency of references to divinities by Conventus ${ }^{17}$

\begin{tabular}{lccc}
\hline & C. Bracarum & C. Lucensis & Total \\
\hline Keltic deity & 65 & 46 & 111 \\
Roman deity; Keltic surname & 22 & 3 & 26 \\
Roman deity & 105 & 52 & 157 \\
Total cultic & 193 & 101 & 294 \\
Total Inscriptions & Ca. 500 & Ca. 300 & Ca. 800 \\
& & & \\
\hline
\end{tabular}

In understanding the transition from 'theirs to ours' we need to recognize the significance of the data in rows two and three. We can [in row 2] see how indigenous peoples adopted the Latin language for an altar and for dedications,

17 For more on this subject see my article, "Indigenous Culture and the Process of Romanization in Iberian Galicia", AJPh 108 (1987) 129-151. 
thereby reflecting their belief that their native gods heard their prayers in the language of their Roman lords. And in row 3, how they syncretized their own deities with those of the Romans formally linking to two names.

Consider these two cases:

Marti Cap/riocieco/L. Hispani/us Fronto/ex voto sacrum [CIL 2, 5612]

and

Albinus/Balesin/i. Lari[b]us/Fin/deneti/icis libe/ns. posui $[\text { cIL 2, 2471 }]^{18}$

In these cases the dedicators have combined deities of traditional Roman religion [Mars and the Lares] with those of the Keltic. Hence, as Tranoy and I believe, Capriociegus must be the Keltic Mars. ${ }^{19}$ But the distribution is also telling: over half of the dedications consist of references to the Lares with some kind of indigenous ethnic signifier. Moreover, dedications to conventional Roman deities in this area reveal a distinctive distribution. That Jupiter replaces Bandua seems clear enough, but the prominence of the Nymphae [nymphs of mountains and of springs] appears to be a regional preference that surely reflects Keltic religious preferences even as the Latin language and Roman conventions are adopted and adapted.

In brief, the epigraphical evidence is very suggestive, and indicates that the Kelts ['them'] selectively adopted features of Roman culture including the language, rituals and forms of hospitium and religious dedications. Nonetheless, they preserved features that were characteristic of their own culture. In other words, peregrines may have made increasing use of the Latin language, but they also applied and adapted that language to their own preferences in respect to social conventions like hospitium and religious worship. Formally, at least in terms of language, they increasingly appeared to be like 'us', but nonetheless retained elements of 'their' indigenous culture and did not perceive that such retention conflicted with their decision to adopt some of the characteristics of

18 There is much uncertainty in the transcription of this text. Some editors see a $p$; others reconstruct the $b$ in Laribus. The Fin/denei/ici has also been read as: Findeneticis or as Pindeneticis or even as Pindeneaicis. Some also see 'periods' others do not. The meaning is, I believe, clear, namely it is dedication in Latin to the local Keltic / ethnic Lares. See Blanca Maria Prosper, Lenguas y religiones prerromanas del occidente de la Península Ibérica, Salamanca, 2002, 318.

19 A. Tranoy, La Galice romaine, Paris (de Boccard, 1981), 304f. J. Nicols, op. cit. 
Roman culture. Hospitium works in such cases because the underlying dynamics were widely understood and judged to be useful.

\section{$4 \quad$ Conclusions}

One of the important findings of modern chaos theory is that seeds of chaos are apparently embedded in order, while the seeds of order seem to be embedded in chaos. Systems that are stable in relation to their environment can become unstable. Systems that are unstable can return to stability. Another important finding is that the behavior of a system in stability and its behavior after becoming unstable are not related in a causal sense.

That apparently ordered systems [like the Roman Empire] embody deep structures of 'chaos' is one such wide-ranging implication of Chaos Theory. And I believe this lesson applies here when we consider the understanding of how hospitium worked, namely, not only to facilitate peaceful exchange on the frontier, but also to promote a process by which the differences between 'ours' and 'theirs' were minimized - all very orderly. However pervasive Romanitas became at one level that should not obscure the persistence of indigenous practices at the local and regional level. Hospitium was attractive because its advantages to both parties were considerable, and because it was sufficiently malleable to be universally recognized and also to encompass a number of local varieties. In hospitium, 'ours' and 'theirs' blended, but did not become identical. 
PART 3

Material Culture and Culture 



\title{
Palmyrenes in Transtiberim: Integration in Rome and Links to the Eastern Frontier ${ }^{1}$
}

\author{
Blair Fowlkes-Childs
}

The subject of Palmyrenes' integration as residents of Rome involves a topic crucial to this workshop, namely, how people from the worlds at the edge of the Empire established new lives when they settled in the capital. Palmyrene expatriates built a temple in Rome's Transtiberim neighborhood where they venerated their civic gods, including Bel, Malakbel, Aglibol, Iarhibol, Astarte and Ares Patroios, most likely during the first third of the second century AD, a period approximately contemporaneous with the construction of the temple of Bel and other Palmyrene gods in Palmyra. ${ }^{2}$ The religious dedications extant in Rome (despite their limited number and often fragmentary condition) attest to the Palmyrenes' strong ties to their city of origin, and in general do not provide much evidence for assimilation in Rome. The remarkable traditionalism of most of the dedications with respect to choices of language, iconography and medium indicates that the dedicators maintained their identities as Palmyrenes (often including their original names and lineage), and were rooted in their own culturally specific religious practices. An elaborate altar dedicated to Sol, Malakbel and other Palmyrene gods, however, stands out, and a new study of its iconography and inscriptions that also considers local religious topography enhances our understanding of Palmyrenes' integration in Rome substantially (Figs. 10.4a-10.4d). The altar's remarkable images and its inscriptions attest to a connection between worshippers of the Roman god Sol and Palmyrenes who venerated Malakbel that is particularly striking because a

1 This article is a modified version of the paper I presented at the nth workshop of IMEM in New York in June 2013. I would like to thank Michael Peachin and Daniëlle Slootjes, the conference organizers and editors of this volume, for all of their assistance. I also thank Amanda Claridge for an informative discussion of marble workshops in Rome.

2 The only object in the Palmyrene corpus in Rome securely linked to a building, perhaps an aedicula, is a fragment of a central piece of a marble entablature with a Greek inscription, dated probably to the reign of Antoninus Pius. IGUR 123; IG XIV, 1035; IGRR I, 47. Rome, Museo Nazionale Romano 40564. $12.5 \times 24 \times 3.5 \mathrm{~cm}$. See also CIS II, 3, 3902 and François Chausson,"Vel Iovi vel Soli: quatre études autour de la Vigna Barberini (191-354)," Mélanges de l'École française de Rome 107 (1995), 671, H. 
porticus for Sol was located in the same neighborhood as the Palmyrene temple (possibly in close proximity). This glimpse of religious life at a local level in Transtiberim indicates that some Palmyrenes were more integrated than most of their dedications suggest, and raises the subject of whether or not some members of the Palmyrene community also participated in religious activities elsewhere in Rome, without leaving discernable records. Lucinda Dirven's observation about foreigners at Dura-Europos applies equally to Palmyrenes in Rome: "strangers who retain markers of their foreignness dominate the picture, whereas they may not be representative necessarily of all the people of a particular region." ${ }^{3} \mathrm{~A}$ reappraisal of the whole Rome corpus is well worthwhile given the recent research on religion in Palmyra and amongst Palmyrene residents of Dura-Europos, on bilingual inscriptions in the Roman world, and on the religious topography of Transtiberim during the imperial period. Above all, an interdisciplinary approach to the material that synthesizes evidence from epigraphy, iconography and topography is essential.

1

\section{Language Choices in the Dedications to Palmyrene Gods Discovered in Rome}

The significance of Palmyrenes' language choices in their dedicatory inscriptions requires evaluation in conjunction with a study of the iconography and medium of each dedication, both in the context of Rome and in comparison with conventions at Palmyra. A few initial observations about language choices may help to frame the discussion overall. Greek and Palmyrene Aramaic dominate the corpus, whereas Latin is rare. The choice to inscribe at Rome in Greek can be interpreted, as J.N. Adams suggests, as a less forceful sign of Palmyrene identity than the decision to use Palmyrene Aramaic: "the dedicators were able to pay lip service to their origins without presenting themselves as out and out aliens, given that the Romans too were devotees of Greek culture and that the city abounded in Greek inscriptions of one sort or another."4 Greek was, of course, readable by a much higher percentage of the local population than Palmyrene was, and several inscriptions are bilingual Greek/Palmyrene. In addition, when Palmyrene is not used, its exclusion raises the question as to whether the dedicators' language choice can be interpreted as a statement

3 Lucinda Dirven, "Strangers and Sojourners: the Religious Behavior of Palmyrenes and other Foreigners in Dura-Europos," in Lisa R. Brody and Gail L. Hoffman (eds.), Dura-Europos: Crossroads of Antiquity (Chestnut Hill, MA and Chicago 2011), 203.

4 J.N. Adams, Bilingualism and the Latin Language (Cambridge 2003), 249 and 251. 
of their permanent settlement in Rome and desire to integrate. ${ }^{5}$ The rarity of Latin is striking, and its use in Rome is an obvious reflection of local context, especially in view of the minor role Latin played in inscriptions at Palmyra. In fact, the city's status as the only publicly bilingual Greek/Aramaic city in the region was unique. ${ }^{6}$ Furthermore, Latin may also not have been considered appropriate for certain religious dedications, as Adams points out with regard to the aedicula and silver statuette dedicated to Aglibol and Malakbel at Rome inscribed in Greek and Palmyrene. ${ }^{7}$

The foundation of a temple for Palmyrene gods in Rome is recorded by two bilingual Latin/Greek inscriptions: the choices of Latin and Greek, and the exclusion of Palmyrene, reflect local context. The references to the emperor are written in Latin only, as Adams notes, and therefore precede the Greek inscriptions in both instances. ${ }^{8}$

CIL VI, 50; ILS, 4334; IGUR, 117; IG XIV, 969; IGR I, 43:

Pro salute Imp (eratoris) [Caesaris --------]

C. Licinius $N$ [------ et Heliodorus]

Palmyrenus [aedem Belo ---------]

constitu[erunt -------]

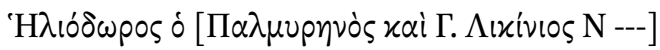

$\tau \dot{\alpha} v \nu \alpha \dot{\partial} v B \dot{n}[\lambda \omega$

$\Pi \alpha \lambda \mu \nu \rho \eta \nu[\hat{\omega} \alpha \dot{\alpha} \theta \dot{\theta} \eta \alpha \nu$----------]

CIL VI, 51; IGUR I, 118; IG, XIV, 970; IGR, I, 44:

[Pro salute Imp(eratoris) Caesaris -----------]

[C. Licinius $N$------ et Heliodorus Palmyrenus]

[ae]dem Belo stat [uerunt ---]

5 See comments by Eugenia Equini Schneider, "Il santuario di Bel e delle divinità di Palmira. Comunità e tradizioni religiose dei Palmireni a Roma," Dialoghi di Archeologia 5 (1987), 84.

6 Ted Kaizer, The Religious Life of Palmyra: a Study of the Social Patterns of Worship in the Roman Period (Stuttgart 2002), 27.

7 Adams 2003, op. cit. (n. 4), 252.

8 Adams 2003, op. cit. (n. 4), 249. 


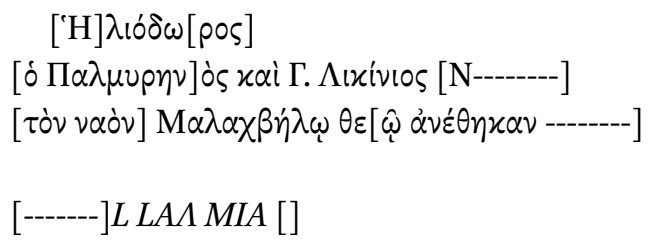

Both the Latin and Greek texts indicate that the gods Bel and Malakbel were distinct, supporting Dirven's argument against their assimilation: "the two gods were worshipped side by side.... thus there is no ground for the assumption that Malakbel replaced Bel. ${ }^{\prime 9} \mathrm{~A}$ temple for Bel is mentioned in $C I L \mathrm{VI}, 5^{1}$

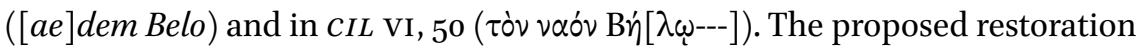

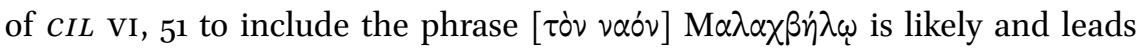
to speculation about whether separate temples for each god existed within the same sanctuary. It should also be noticed that the same benefactors are mentioned in both inscriptions. Although only Heliodorus is identified specifically as a Palmyrene, the gentilicium Licinius is attested four times at Palmyra, and may indicate that the benefactor in Rome belonged to a Palmyrene family, known to have belonged to the priest class, and which had gained Roman citizenship. ${ }^{10}$

Several aspects of the temple of Bel at Palmyra are relevant to a clearer understanding of the Palmyrene temple in Rome, with respect both to the gods worshipped as well as the roles of private benefactors. Ted Kaizer's cautionary assessment must however be kept in mind: "the religion of Palmyrene expatriates cannot simply be explained as copying the religious world of their hometown, and different social and economic conditions are known to have had a strong effect on the choice of deities to whom dedications were made."11 $\mathrm{He}$ establishes that the name "temple of Bel" became typical at Palmyra, but is in fact a "simplification of the actual cultic situation," which included the veneration of numerous Palmyrene gods together: inscriptions dated to both the early first century $\mathrm{AD}$ and to the second half of the second century refer to a "temple of Bel" and to the "house of the gods of the Palmyrenes." In addition to the gods Iarhibol and Aglibol, the goddess Astarte, for example, was worshipped

Lucinda Dirven, The Palmyrenes of Dura-Europos: A Study of Religious Interaction in Roman Syria. Religions in the Graeco-Roman World 138 (Leiden 1999), 173. For a comprehensive recent analysis of the god Bel, see Michał Gawlikowski, "Bel of Palmyra," in Michael Blömer, Achim Lichtenberger and Rubina Raja (eds.), Religious Identity in the Levant from Alexander to Muhammed: Continuity and Change. Contextualising the Sacred (Leuven 2014), 4, 247-254.

$10 \quad$ Equini Schneider 1987, op. cit. (n. 5), 71-72.

11 Kaizer 2002, op. cit. (n. 6), 112. 
alongside Bel at Palmyra, and her cult image very likely housed in the south adyton, newly built in the second half of the first century. ${ }^{12}$ Rather than a major imperial benefaction, as had previously been supposed, Kaizer's study of the epigraphic corpus reveals that individual Palmyrene citizens financed the temple's construction over a prolonged period: ${ }^{13}$ the building of the cella extended into the second century. ${ }^{14}$ In Rome, private benefactors fulfilled comparable roles as temple founders and benefactors, and the two dedicatory inscriptions potentially point to direct interconnections between the Palmyrenes resident in Rome and those back home.

Two inscribed marble relief sculptures reflect Palmyrene conventions with regard to the deities venerated, epigraphic formulas, iconography and their actual format as reliefs; when evaluated in conjunction with recent research on religion at Palmyra, both contribute to an understanding of Palmyrene identity and religious life in Rome despite their fragmentary condition. The relief dedicated to Bel, Iarhibol and probably also Aglibol features a bilingual Palmyrene/ Greek inscription that emphasizes the dedicator Maqqai/Makkaios' lineage, in accordance with the typically Palmyrene focus on ancestry (Fig. 10.1).

IGUR 120; IG XIV, 972; IGRR I, 46; CIS II, 3904; PAT 0249:

English translation of the Palmyrene Aramaic (Adams 2003, 251).

[To Bel, Iarhibol and Aglibol: made (this)

Maqqai son of Male (son of) Lišam] š and

Šo'adu son of Taime (son of) Lišamšai, and

offered (it).

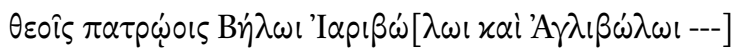

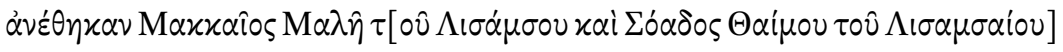

12 Kaizer 2002, op. cit. (n. 6), 70 and 198-200; Ted Kaizer, "Reflections on the Dedication of the Temple of Bel at Palmyra in A.D. 32," in Lukas de Blois, Peter Funke and Johannes Hahn (eds.), The Impact of Imperial Rome on Religions, Ritual and Religious Life in the Roman Empire: Proceedings of the Fifth Workshop of the International Network of Empire (Roman Empire, 200 B.C.-A.D. 476) (Leiden 2006), 96 and 104-105.

13 Kaizer 2002, op. cit. (n. 6), 67-71 (with references) and Kaizer 2006, op. cit. (n. 12), 95.

14 Gawlikowski 2014, op. cit. (n. 9), 248-249; see also Michał Pietryzkowski, Adyta światyń palmyreńskich. Studium funkcji i formy (Warsaw 1997). 


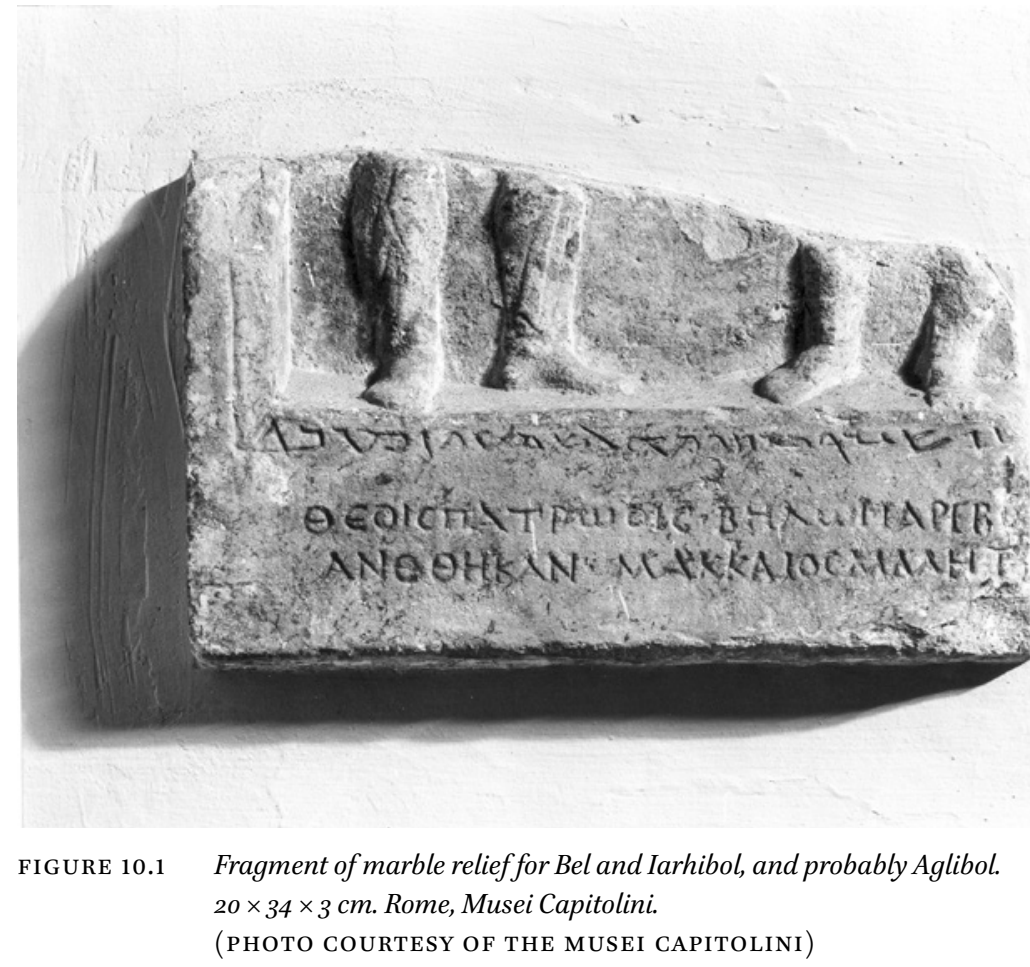

It is possible to reconstruct the relief's original iconography: the boots and the lower sections of the trousers of two figures are extant, enough to indicate that the relief most likely originally depicted the gods Bel and Aglibol dressed in their usual outfits, which included cuirasses and mantles as well as trousers. Bel is typically crowned with a polos and diadem, holding a scepter in his right hand and a sword in his left. He is most likely identifiable with the figure on the right, since he usually appears in the center of a divine trio, with Iarhibol on his right and Aglibol on his left, leading to the identification of the second figure as Aglibol. Such close adherence to conventional Palmyrene representations of divinities suggests strong ties between the dedicators in Rome and their home city.

The marble relief fragment that depicts the head of the goddess Astarte wearing a kalathos and a veil, with her name inscribed in Greek in the frame, is another example of traditionalism with respect to language and iconography in the corpus, as well as of ties to Palmyra (Fig. 10.2)..$^{15}$

15 Carlo Ludovico Visconti, "Escavazioni della Vigna Bonelli fuori della Porta Portese negli anni 1859 e 6o," Annali dell'Istituto di corrispondenza archeologica 32 (1860), 423-424, thought that the Astarte figure belonged to the same relief as the Bel, Iarhibol and Aglibol 


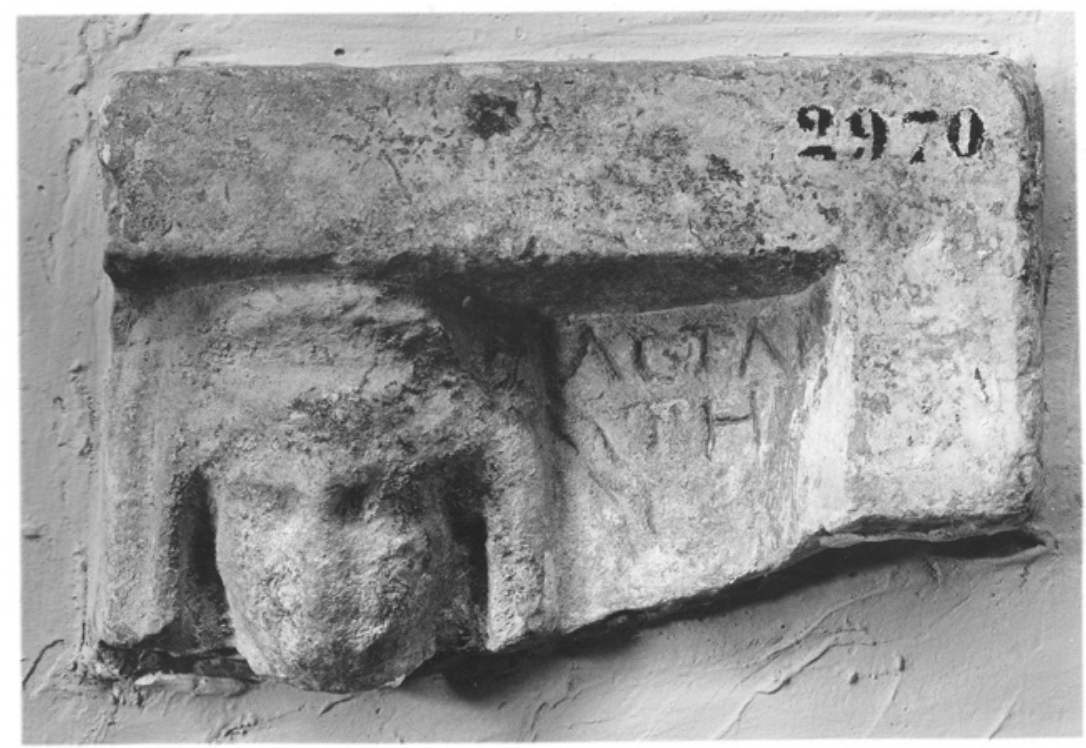

FIGURE 10.2 Fragment of marble relief with head of Astarte. $12 \times 18 \mathrm{~cm}$. Rome, Musei Capitolini 2970.

(PHOTO COURTESY OF THE MUSEI CAPITOLINI)

IGUR 120:

'A $\sigma \tau \alpha \dot{\rho}$

$\tau \eta$

Astarte's significant role alongside other divinities is well-attested at Palmyra, as discussed previously: she was venerated alongside Bel and her cult image apparently placed in an adyton added to the temple of Bel and Palmyrene gods during the second half of the first century AD. ${ }^{16}$ The relief has been linked erroneously to the goddess Dea Syria in Transtiberim in conjunction with the proposal that a sanctuary for Dea Syria existed in the neighborhood; however, it clearly belongs to the Palmyrene corpus, and no other dedications to Dea Syria (or to any other Syrian goddess) have secure archaeological provenances that attribute them to the area in question. ${ }^{17}$ The veneration of Astarte in Rome by

relief. Carlo Pietrangeli, Musei Capitolini. I monumenti dei culti orientali (Rome 1951), 14, cat. no. 15, subsequently discredited the idea due to the fragments' different depths.

16 Pietrzykowski 1997, op. cit. (n. 14); Kaizer 2002, op. cit. (n. 6), 198-200, and 2006, op. cit. (n. 12), 96 and 104-105. See also Dirven 1999, op. cit. (n. 9), 71.

17 See Blair Fowlkes, "The Cults of Syrian-Phoenician Gods in Rome: Archaeology, Topography, and Connections to the Roman East," Ph.D. diss. (New York University 2012), 
a Palmyrene therefore points toward a specific connection to Palmyra, rather than to integration in local religious life.

\section{$4 \quad$ Altar for Ares Patroios}

A marble altar dedicated to Ares Patroios embodies Palmyrene traditionalism with regard to (a) the choice of Greek for the inscription, (b) the use of the Seleucid calendar, and (c) the local incarnation of the god himself. Ares, in this instance, is considered to be the god Arşu, whose temple at Palmyra was one of four sanctuaries dedicated to the dei patri. ${ }^{18}$ The choice of Greek, as discussed above, reflects Palmyrene identity much less blatantly than does the Palmyrene language in the context of Rome. In contrast, the selection of an altar typical of dedications to all sorts of gods in Rome is significant as a reflection of the dedicator's integration at the capital.

IGRR I, 33; IGUR 122; IG XIV, 962:

April AD 134

' $\pi \dot{\rho} \rho \tau \eta ิ \varsigma \sigma \omega \tau \eta \rho \mid \alpha \varsigma$

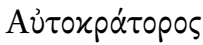

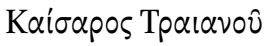

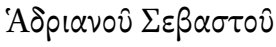

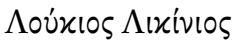

'Epuias

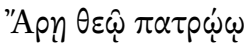

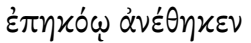

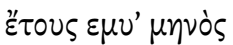

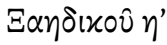

213-219, for full discussion. For proposals of a sanctuary for Dea Syria see in particular Serena Ensoli, "Communauté et cultes syriens à Rome: les sanctuaires de la regio XIV Transtiberim," in Jacques Charles-Gaffiot, Henri Lavagne, and Jean-Marc Hofman (eds.), Moi, Zénobie, reine de Palmyre (Milan 2001), 123-128; Serena Ensoli, "Il santuario della Dea Syria e i culti palmireni nell'area meridionale di Trastevere," Orizzonti 4 (2003), 45-59; Hans J.W. Drijvers, "Die Dea Syria und andere syrische Gottheiten im Imperium Romanum," in Maarten J. Vermaseren (ed.), Die orientalischen Religionen im Römerreich (Leiden 1981), 241-263.

18 Equini Schneider 1987, op. cit. (n. 5), 72 and note 20. 
The dedicator Lucius Licinius Hermias shares the same gentilicium as the benefactor named in $C I L \mathrm{VI}, 50$ and 51 discussed previously; so again, there is perhaps a connection here to the Licinii back in Palmyra.

\section{5}

An aedicula (and a Silver Statuette) for Aglibol and Malakbel

The Palmyrene dedication with the latest date extant in Rome is a lavish marble aedicula dated to February 236 : the conventionalism of the depictions of Aglibol and Malakbel, and of the dedicatory inscriptions, is noteworthy (Fig. 10.3). Dressed in a cuirass and cloak, Aglibol, on the right, holds a lance in his left hand and a radiate nimbus and lunar crescent are visible behind his head. Malakbel wears a diadem and the characteristic Palmyrene outfit of trousers, a short tunic and an open overcoat. The gods shake hands in front of a cypress tree between them: the handshake as a gesture of "alliance" has been interpreted as a sign that the two gods represent the "Sacred Brothers" mentioned in various Palmyrene texts, venerated together in a sacred grove and depicted on a relief from the temple of Bel and Palmyrene gods at Palmyra. ${ }^{19}$

The adherence to customary Palmyrene iconography is matched by the choices of Greek and Palmyrene and the emphasis placed on the dedicator's ancestry: Adams suggests also that Latin may not have been appropriate for this type of religious dedication. ${ }^{20}$ Iarhai (translated into Greek as Heliodoros, according to Palmyrene convention) dedicated the aedicula, and a silver statuette, to Aglibol and Malakbel for his own and his son's well-being.

IGUR 119; IG XIV, 971; IGRR I, 45:

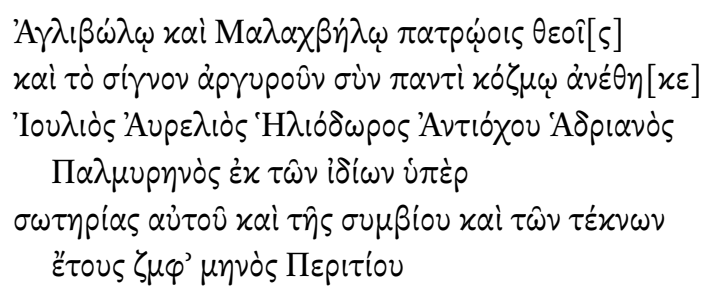

\footnotetext{
19 See Equini Schneider 1987, op. cit. (n. 5), 82 and note 71 for additional references. See also Dirven 1999, op. cit. (n. 9), 175 and Fig. 17.

$20 \quad$ Adams 2003, op. cit. (n. 4), 252.
} 


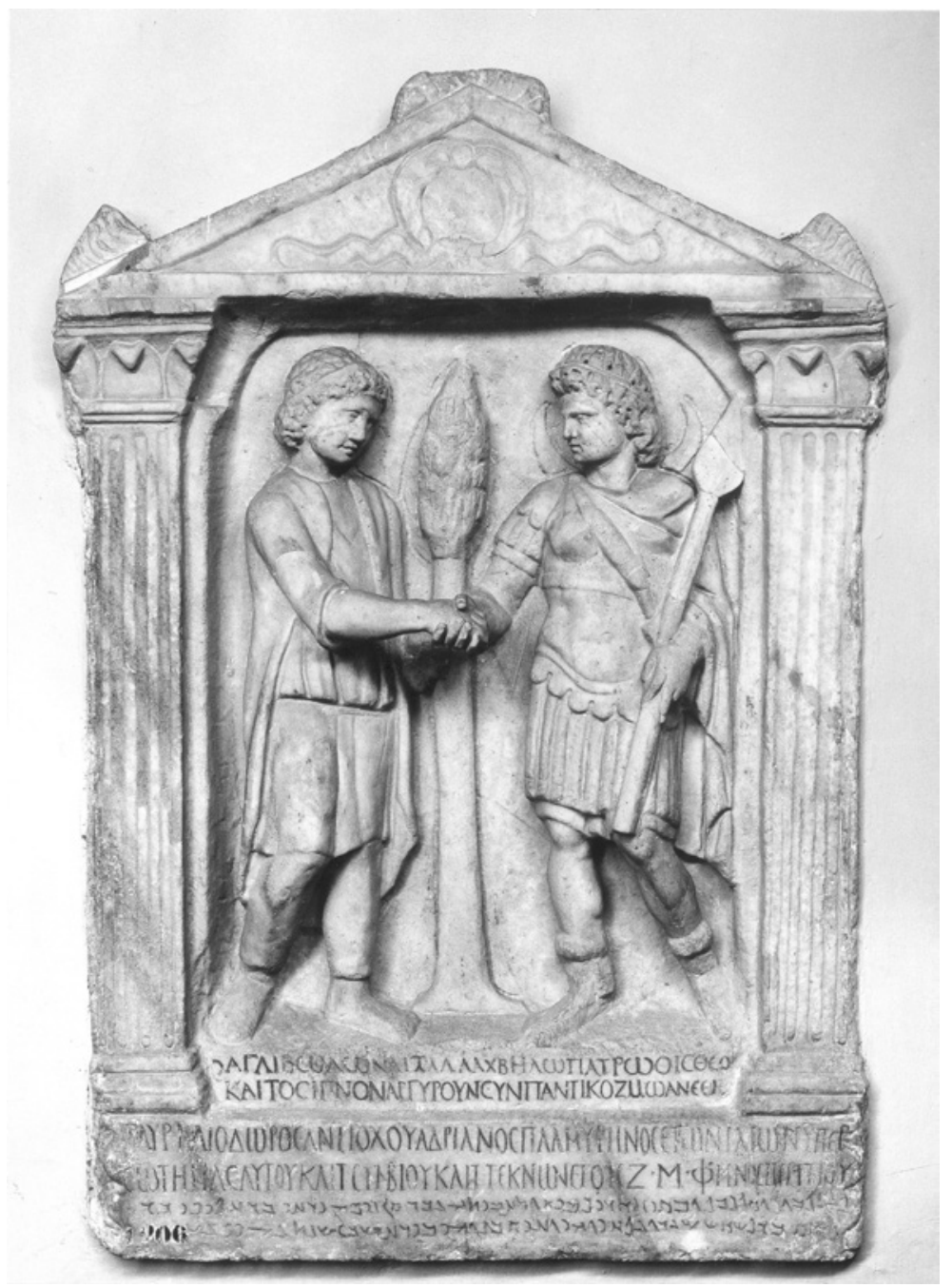

FIGURE 10.3 Marble aedicula for Aglibol and Malakbel. February 236. $97 \times 63 \mathrm{~cm}$. Rome, Musei Capitolini 1206.

(PHoto COURTESY OF THE MUSEI CAPITOLINi)

CIS II, 3, no. 3902; PAT 0247:

English translation of the Palmyrene Aramaic (Adams 2003, 251-252)

To Aglibol and Malakbel: both the silver statue and its decoration Iarhai son of Haliphai, son of Iarhai, son of Lisams (son of) Šo'adu made from his purse for his own safety and that of his sons; in the month Shebat of the year 547 . 
As a group, the two dedicatory inscriptions, the two relief sculptures, the altar for Ares Patroios and the aedicula for Aglibol and Malakbel illustrate how members of the Palmyrene community in Rome explicitly expressed connections to their native city's civic religion and customs. Traditionalism prevails in general with regard to choices of language and iconography, with a couple of exceptions as noted, including the use of Latin for dedicatory inscriptions and the choice of an altar for Ares Patroios rather than a relief sculpture.

A lavish marble altar dedicated to Sol, Malakbel and additional unspecified Palmyrene gods is the most renowned object in the corpus of Palmyrene religious dedications from Rome, standing out vividly with respect to its iconography, the use of Latin for one of the two dedicatory inscriptions, and the information available about the dedicators' identities (Figs. 10.4a-10.4d). A production date in the early second century is likely. ${ }^{21} \mathrm{~A}$ reevaluation of this monument is essential in order not only to integrate the study of its imagery and inscriptions, but also to consider local religious topography and its possible original display context fully. I propose that the dedicators commissioned a monument that distinguishes purposefully between the gods Sol and Malakbel, and most likely commemorates two distinctive dedications, as recorded in Latin and Palmyrene inscriptions that are not translations of one another. Analysis of the identities of the two gods and of the dedicators raises key questions about Palmyrenes' degree of assimilation in Rome and about connections between different cult sites. The exact location of the Palmyrene temple is indeterminable; however, a porticus for Sol (and probably a sanctuary as well) was apparently located nearby, and supports the idea that the Sol/ Malakbel altar honors both gods individually. Ultimately, by focusing on the glimpse of religious interaction in Rome the altar provides, in contrast to the rest of the corpus, this new interpretation of a complex monument heightens our understanding of the integration of foreigners and links between the capital and the empire's frontiers. ${ }^{22}$

21 See the discussion by George W. Houston, "The Altar from Rome with Inscriptions to Sol and Malakbel," Syria 67 (1990), 191-192, who revises the third-century date proposed most recently by Javier Teixidor, The Pantheon of Palmyra. Études preliminaires des religions orientales 79 (Leiden 1979), 50.

22 For a bibliography and substantial discussion of previous theories, see Dirven 1999, op. cit. (n. 9), 175-180 and accompanying notes. See in particular also Equini Schneider 1987, op. cit. (n. 5), 73-78; Henry Stuart Jones (ed.), A Catalogue of the Ancient Sculptures 

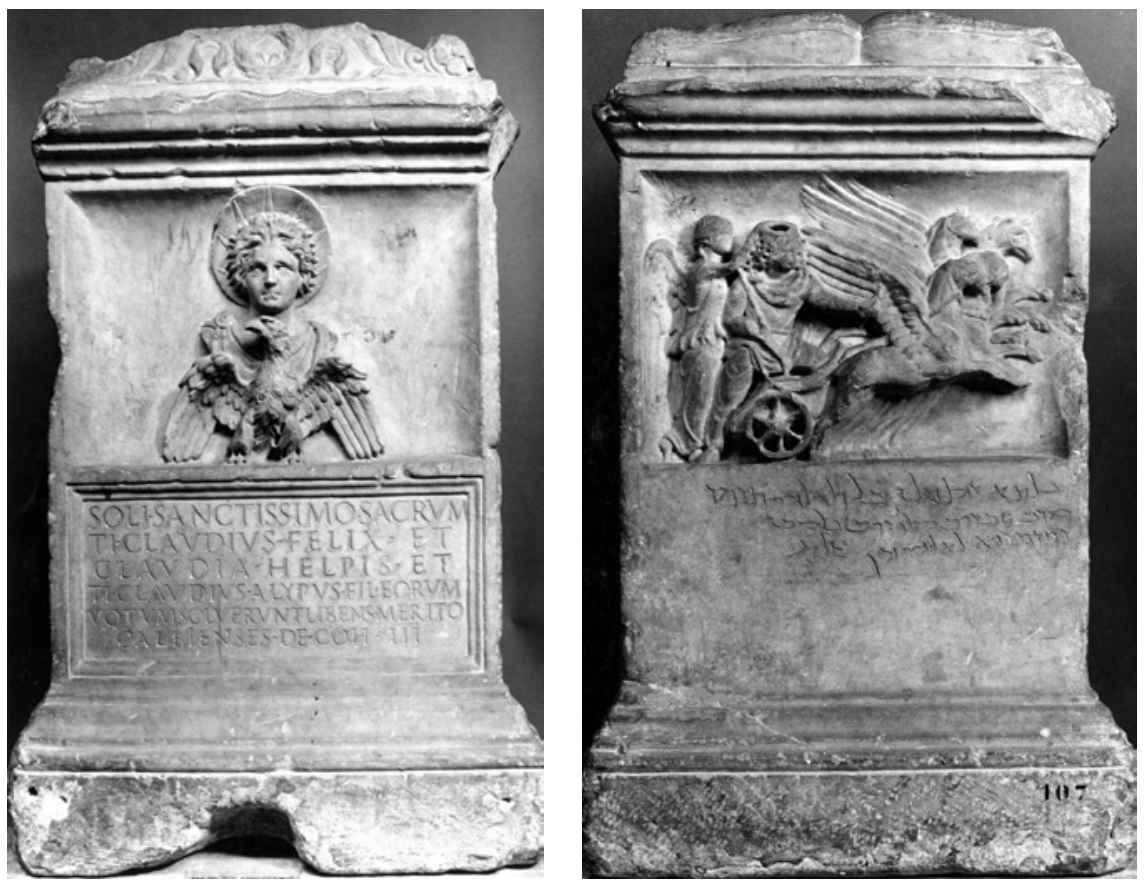

$10.4 \mathrm{~A}$

$10.4 \mathrm{~B}$
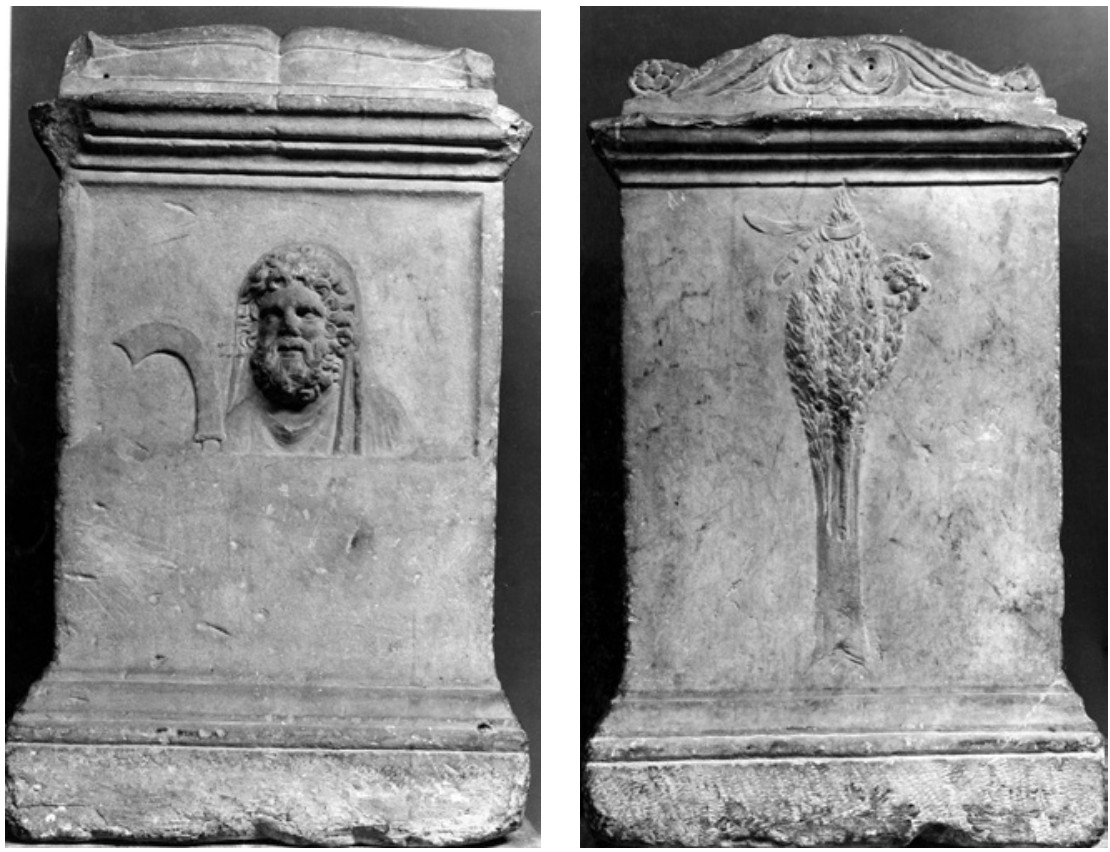

$10.4 \mathrm{C}$

$10.4 \mathrm{D}$

FIGURE 10.4 4a and b. Sol/Malakbel Altar. $84 \times 52 \times 52 \mathrm{~cm}$. Rome, Musei Capitolini, NCE 2412. Fig. $4 \mathrm{c}$ and d. Sol/Malakbel Altar.

(PHOTO COURTESY OF THE MUSEI CAPITOLINI) 
The altar's most prominent side, due to the orientation of the pulvini, features a bust of Sol carved in high relief placed on an eagle above a straightforward Latin inscription, which records a dedication to Sol Sanctissimus by Tiberius Claudius Felix, his wife Claudia Helpis and their son Tiberius Claudius Alypus (Fig. 10.4a). The choice of Latin is of course entirely appropriate for a dedication to Sol in the context of Rome, but stands out as noteworthy in comparison with the other language choices made throughout the corpus of Palmyrene dedications in Rome discussed previously.

CIL VI, $710=30817 ;$ ILS 4337:

\author{
Soli sanctissimo sacrum \\ Ti(berius) Claudius Felix et \\ Claudia Helpis et \\ Ti(berius) Claudius Alypus fil(ius) eorum \\ votum solverunt libens merito \\ Calbienses de coh(orte) III
}

George Houston solved the puzzle of the meaning of the term Calbienses by identifying the three dedicators as residents of the third courtyard of the Horrea Galbana in the Emporium zone on the right bank of the Tiber. ${ }^{23}$

Turning to the image of Sol, the idea that the figure represents Malakbel in his role as a solar deity ${ }^{24}$ is unconvincing in view of the use of the standard iconography of Sol and the fact that the dedicators were apparently civilians. Above all, one must consider the significance of such a representation for a contemporary viewer in the city of Rome (the dedicators included), whether or not this audience was able to read the Latin inscription. No hint of any Palmyrene connections is evident: the figure's appearance and pose

Preserved in the Municipal Collections of Rome: the Sculptures of the Palazzo dei Conservatori (Oxford 1926), 47, no. 1 and Pietrangeli 1951, op. cit. (n. 16), 21, no. 33. Werner Herrmann, Römische Götterältare (Kallmunz 1961), 113, provides a detailed description of the altar's type and design.

23 Houston 1990, op. cit. (n. 21), 191: the term Calbienses was interpreted previously as a Palmyrene tribal affiliation. He cites Rodríguez Almeida's study of the horrea Galbae and explains that the building with three courtyards is in fact living quarters, not a warehouse (Emilio Rodríguez Almeida, "Cohortes III Horreorum Galbanorum." Rendiconti della Pontificia Accademia di Archeologia di Roma 50 (1977-78), 9-25).

24 Equini Schneider 1987, op. cit. (n. 5), 81; Dirven 1999, op. cit. (n. 9), 178. The term sanctissimus is apparently a rare epithet for the god Sol, however, and therefore Steven Hijmans, "Sol. The Sun in the Art and Religions of Rome," (Ph.D. diss. Universiteit Groningen 2009), 506, note 9o, characterizes Sol in this instance as equated with Malakbel. 
reflect conventional Roman iconography for the god Sol. He is youthful, beardless and radiate, depicted in bust form above an eagle: the similar image of Sol on a cippus dedicated by a wine merchant provides an apt comparison (Fig. 10.5). A frumentarius' dedication to Sol Invictus Malachbelus discovered in Rome indicates that Malakbel could be linked to Sol Invictus in the capital; ${ }^{25}$ however, the fact that the dedicator was a member of the military is notable. Dirven strongly emphasizes the differences between merchants' and soldiers' religious choices in her study of Palmyrene gods at Dura-Europos, and comments specifically on Malakbel's role as a solar deity among the military. ${ }^{26} \mathrm{In}$ brief, there is no reason to conclude from the iconography, from the Latin inscription, or from the dedicator that the radiate figure on the Sol/Malakbel altar represents any deity other than the Roman god Sol.

On the altar's left side, a representation of Malakbel appears above a Palmyrene inscription that records a dedication to Malakbel and the gods of Palmyra by Tiberius Claudius Felix and the Palmyrenes (Fig. 10.4b). ${ }^{27}$ Victory crowns Malakbel as he climbs into a chariot pulled by four winged griffins: he wears trousers and a mantle and holds a spear in his right hand. The scene is comparable to one on an altar from the sanctuary of Baalshamin at Palmyra:28 both representations very likely copy a cult image of Malakbel at Palmyra, and the dedicators of the Rome altar therefore emphasize their connection to their home city through a deliberate iconographic choice.

Information from the Palmyrene inscription about the dedicators and their relationships with one another underscores the complexity inherent in an attempt to identify foreigners and assess their level of integration in Rome. Three English translations of the Palmyrene inscription merit inclusion due to their slightly different characterizations of the dedicators' roles. A deliberate distinction between two groups of dedicators is apparent, regardless of Claudius Felix's involvement in both, since the Latin inscription refers to an

$25 C I L$ VI, $31036=$ ILS 4338. [D]eo Soli Inv[icto] / Malachibe[lo] / Aelius Long[---] / (centurio) frument(arius) / pr [o salute --- ]/[---]liae / [---]niv[--]. Museo Nazionale Romano. See also Equini Schneider 1987, op. cit. (n. 5), 80; Chausson 1995, op. cit. (n. 2), 679, Pbis; Hijmans 2009, op. cit. (n. 24), 495-496, l.

26 Dirven 2011, op. cit. (n. 3), 201-220; Dirven 1999, op. cit. (n. 9), 170 and 181-183.

27 Teixidor 1979, op. cit. (n. 21), 47.

28 Palmyra Museum. Dirven 1999, op. cit. (n. 9), 161-162 and pl. xxıII: she also mentions another possible representation of Malakbel from the temple of the Gaddé at DuraEuropos and two tesserae from Palmyra representing a deity in a quadriga pulled by griffins. See also Equini Schneider 1987, op. cit. (n. 5), 78 and Fig. 10. 


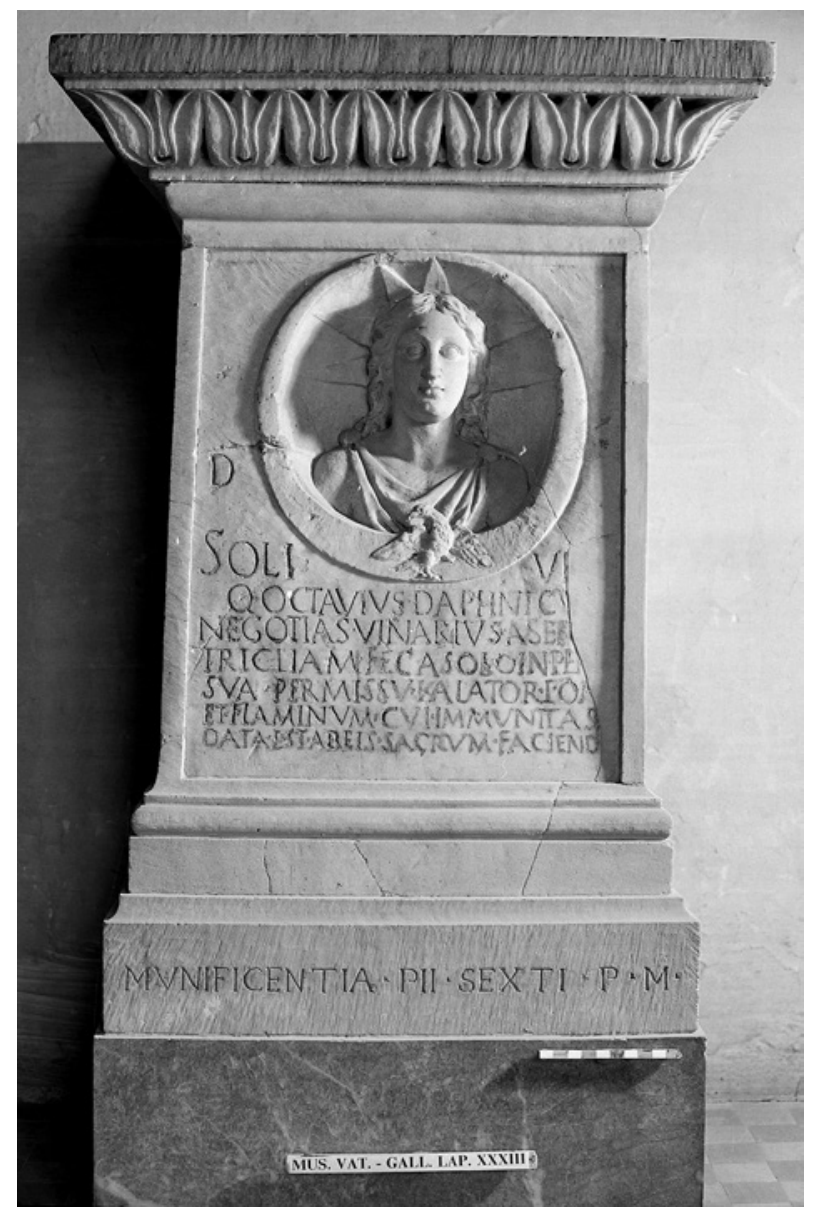

FIGURE 10.5 Cippus for Sol. Musei Vaticani.

(PHOTO COURTESY OF THE MUSEI VATICANI)

earlier vow made by Tiberius Claudius Felix, his wife and their son, as Houston emphasizes. $^{29}$

CIS II, no. 3903; PAT 0248.

CIS II, no. 3903:

Tiberius Claudius Felix has offered this altar to

Malakbel and the gods of Palmyra. And the

Palmyrenes (have offered it) to their gods. Peace.

29 Houston 1990, op. cit. (n. 22), 192-193. 


\section{Teixidor 1979, 47:}

This is the altar (which) Tiberius

Claudius Felix and the Palmyrenes

offered to Malakbel and the gods of

Palmyra. To their gods. Peace!

\section{Dirven 1999, 177:}

This altar (is) for Malakbel and the gods of

Palmyra. Tiberius Claudius Felix and the Palmyrenes offered it to their gods.

Peace.

Debate centers on Tiberius Claudius Felix's origins, occupation, and connection to the "Palmyrenes" mentioned. Adams characterizes him as a Palmyrene too, whose acculturation leads him to adopt a Latin name completely, and mentions "his assimilation and desire to present a Roman identity alongside the Palmyrene." ${ }^{30}$ The wording of the inscription, however, separates him clearly from "the Palmyrenes" about whom no additional information is provided. The possibility that they were slaves of the imperial household ${ }^{31}$ may explain Claudius Felix's role as a facilitator of the dedication if he were an imperial freedman, but does not indicate that he was necessarily a Palmyrene himself. In any case, whatever his ancestral origins actually were, his specific desire to identify himself with a Latin name separately from the "Palmyrenes" is clear.

The marble altar itself, in addition to the actual figures carved in relief, was most probably a commissioned work in view of its size and high quality: all four sides may have been clearly visible in the altar's original setting, since the carving on the two uninscribed sides is detailed..$^{32}$ The Sol side is visually the most prominent due to the orientation of the pulvini, as mentioned: the fact that two sides are inscribed, however, indicates that both may have been of equal

$30 \quad$ Adams 2003, op. cit. (n. 4), 250-53. Equini Schneider 1987, op. cit. (n. 5), 77 and notes 41 and 42 , suggests that he is a libertus connected to the horrea, rather than a vilicus, who would most likely be a slave, and also argues in favor of his Palmyrene origin. David Noy, Foreigners at Rome: Citizens and Strangers (London 2000), and Dirven 1999, op. cit. (n. 9), 179-80, do not believe that Tiberius Claudius Felix is definitely a Syrian.

$31 \quad$ Equini Schneider 1987, op. cit. (n. 5), 77.

32 For a discussion of sculptors' workshops in Rome, see Amanda Claridge, "Marble Carving Techniques, Workshops, and Artisans," in Elise A. Friedland and Melanie Grunow Sobocinski (eds.), The Oxford Handbook of Roman Sculpture (Oxford and New York, 2015), $113^{-114}$ 
importance to the dedicators irrespective of the pulvini. The figures depicted on the altar's two other sides are not easily identifiable. The most straightforward explanation is that they represent the unnamed Palmyrene gods mentioned in the Palmyrene inscription. Alternatively, the bearded male figure with a mantle pulled over the back of his head and a scythe on the altar's right side could represent Saturn (Fig. 10.4C). ${ }^{33} \mathrm{~A}$ tall cypress tree on the altar's rear side has a ribbon in its top branches and the figure of a boy with a goat on his shoulders emerges from the top right of the tree (Fig. 10.4d). The tree is a possible reference to a cult site for Malakbel in a sacred grove and the young boy could represent him in his role as an agrarian deity.

An understanding of local religious topography derived from epigraphic and archaeological evidence corroborates the idea that the Sol/Malakbel altar commemorates two distinctive dedications, raises the question of its original display context, and draws attention to the "cultic realities on the ground,"34 to borrow Kaizer's words, that provide a glimpse of Palmyrenes' integration within Rome. Almost all of the dedications to Palmyrene gods were discovered in 1859 during Carlo Ludovico Visconti's excavations at the Vigna Bonelli in Trastevere outside the Porta Portese: precise information about the location of the archaeological site or about architectural structures is unavailable. ${ }^{35}$ The Vigna Bonelli's boundaries are marked on Giambattista Nolli's 1748 Pianta di Roma labeled with the property's previous name, Vigna Crescenzi (Fig. 10.6). Additional inscriptions also discovered at the Vigna Bonelli indicate that a porticus of Sol separate from the Palmyrene temple existed: it was administered by the priesthood of kalatores and therefore connected to a public Roman cult of the god. In his comprehensive study of Sol, Steven Hijmans cites the "unfounded communis opinio of earlier scholarship that the cult of Sol in the imperial era was of Syrian origin" as the reason for persistent confusion between the cult sites for Palmyrene gods and for Sol. ${ }^{36} \mathrm{He}$ also draws

33 See also Dirven 1999, op. cit. (n. 9), 178 and note 75.

$34 \quad$ Kaizer 2002, op. cit. (n. 6), 58.

35 The aedicula and the Sol/Malakbel altar do not have secure archaeological provenances and both were part of the Mattei family's antiquities collection. Christian Hülsen, Römische Antikengärten des XVI. Jahrhunderts (Heidelberg 1917), 62, no. 53, gives no information about the aedicula's archaeological provenance. Pirro Ligorio and the $C I L$ editors report that the Sol/Malakbel altar was found in the vigna of Mario Scapuccio on the Janiculum hill: see Fowlkes 2012, op. cit. (n. 17) 191-193 for references. CIL VI, $5^{1}$ (now in the British Museum) is the only other object not discovered during the excavations. See Visconti 1860, op. cit. (n. 15), 415-450.

36 Hijmans 2009, op. cit. (n. 24), 486 and 501. See also Steven Hijmans, "The Sun which did not rise in the East; the Cult of Sol Invictus in the Light of Non-Literary Evidence," Bulletin 
attention to an aedicula for Silvanus also discovered during the 1859 Vigna Bonelli excavations as an additional important piece of evidence that various sanctuaries/cult sites were located in the same general area, despite the dearth of information about their precise locations. ${ }^{37}$

$C I L \mathrm{VI}, 31033^{1}$ and $C I L$ VI, $5^{2}$ both refer respectively to a porticus of Sol and triclias, likely a variant spelling of trichila, defined as a "gazebo" or "bower". 38 CIL VI, 310331 records that the benefactor, Iulius Anicetus, restored the porticus with the kalatores' permission in AD 102. ${ }^{39}$ The mention of a porticus, but not an aedes, is apparently a rare occurrence, and perhaps an indicator that the sanctuary was open-air, typical for Sol. ${ }^{40} C I L$ VI, $5^{2}$ records Anicetus' request that the walls and triclias of the sanctuary not be written on or defaced. ${ }^{41}$ Hijmans' comments on the two inscriptions are worth quoting in full, as he draws a crucial distinction between the gods Bel and Sol and their respective cult sites:

Antieke Beschaving 71 (1996), 115-150. Visconti 186o, op. cit. (n. 15), 424; Luigi Borsari, "Del gruppo di edificii sacri al Sole nell'area degli orti di Cesare," Bullettino della Commissione Archeologica di Roma 15 (1887), 9o; Palmer 1981, op. cit. (n. 33), 372-373, and Chausson 1995, op. cit. (n. 2), 663-664. Equini Schneider concurs that the Sol inscriptions are not relevant to the cult of Bel (s.v. "Belus/Malachbelus," LTURS I (2001) 218 (E. Equini Schneider). Robert E.A. Palmer, "The Topography and Social History of Rome's Trastevere (Southern Sector)," Proceedings of the American Philosophical Society 125.5 (1981), 372-373, proposes a "sanctuary of the Sun" on the Via Longa Aquilae; Chausson 1995, op. cit. (n. 2), 663-664 follows this interpretation. Serena Ensoli attributes epigraphic evidence from multiple cult sites to one major sanctuary in Reg. XIV, which she refers to as the "santuario siriano" (“Deae Syriae Templum (280)," LTURS II (2002), 192 (S. Ensoli) and Ensoli 2003, op. cit. (n. 17), $5^{2}$.

37 CIL VI, 642; Hijmans 2009, op. cit., (n. 24), 489, h; Visconti 1860, op. cit. (n. 15), 448-450.

38 Palmer 1981, op. cit. (n. 35), 375, suggests that open-air rooms may have been connected to, or part of, the porticus. Chausson 1995, op. cit. (n. 2), 667, suggests that the term is an abbreviation for triclinium. See also Hijmans 2009, op. cit. (n. 24), 503.

$39 \quad C I L$ VI, $3719=310331$. The inscription was discovered during two different nineteenthcentury excavations: Visconti 1860 , op. cit. (n. 15), reports that the bottom half was unearthed during Giambattista Guidi's 1859 excavation, and Rodolfo Lanciani found the top half in 1884 (Carlo Ludovico Visconti and Rodolfo Lanciani, "Il busto di Anacreonte scoperto negli orti di Cesare," Bullettino della Commissione archeologia di Roma 12 (1884), 25-38). Hijmans 2009, op. cit. (n. 24), 486 and note 23; 492, k; C2b.2: he also notes (151) that a Neronian foundation date is plausible in comparison with other Sol sanctuaries throughout the city.

$40 \quad$ Hijmans 2009, op. cit. (n. 24), 503 and note 72.

41 The wine merchant's altar for Sol, discussed previously, mentions a triclia as well, and is also, therefore, attributable to the same Sol sanctuary (it was discovered in the Tiber near the Ponte Rotto) (Fig. 5). 


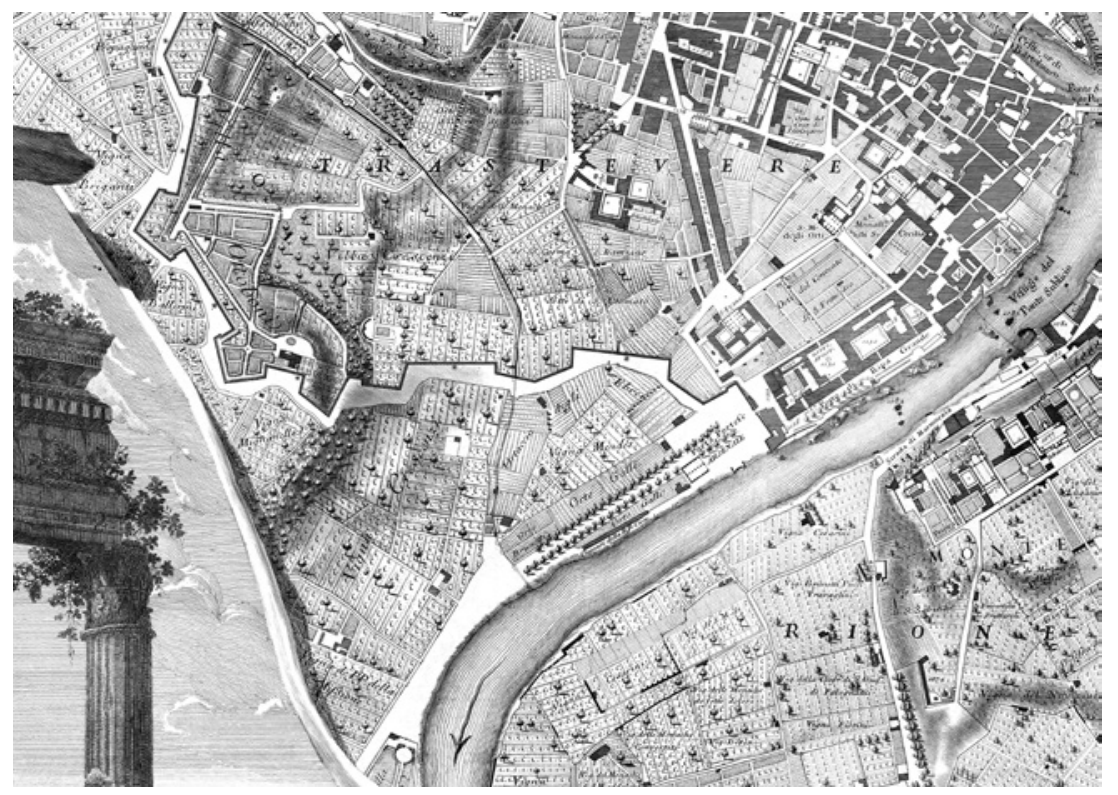

FIGURE 10.6 Detail of Giambattista Nolli's 1748 Pianta di Roma. The Vigna Crescenzi (later named the Vigna Bonelli) is circled.

(COURTESY OF THE NOLLI MAP PROJECT, UNIVERSITY OF OREGON, HTTP://NOLLI.UOREGON.EDU)

There is no evidence that Anicetus' porticus was connected to the temple of Bel, and strong reasons to think that it was not. To begin with, Bel is not Sol, and the inscription cannot, therefore, refer to a porticus "of the temple of Bel". In the second place, the inscriptions of Anicetus give no evidence of any Palmyrene connections: their language is Latin only, the deity is given a Latin name with no indication that a non-Roman deity is meant, permission of the kalatores pontificum et flaminum is involved, implying Roman rather than foreign cult, and the consular rather than the Seleucid dating system is used. The only reasonable conclusion is that Anicetus' inscriptions belong to a portico (and sanctuary?) of Sol that stood in the same general area but was unrelated to a Palmyrene sanctuary of Bel. ${ }^{42}$

Despite the limited archaeological evidence from the Vigna Bonelli site, Hijmans' convincing reinterpretation of the epigraphic evidence for the porticus and the Palmyrene temple dispels previous confusion about local religious topography. 
Choices of language, iconography and medium throughout their corpus of dedications illustrate how purposefully and openly numerous Palmyrenes in Rome emphasized their links to Palmyra, providing insight into a community of foreigners within the capital. The specific mention of different dedicators in distinctive inscriptions, the iconography and religious topography all support the idea that the Sol/Malakbel altar commemorates separate dedications to the Roman god Sol and to Malakbel and Palmyrene deities, linked together by Tiberius Claudius Felix's involvement in both. The question arises whether such a monument was originally dedicated and displayed at the Sol porticus or at the Palmyrene temple, or perhaps at another location. In any case, the altar indicates that Palmyrenes (or at least a particular group of them) most likely had a connection/level of access to the Sol porticus in addition to their own temple, an important sign of integration in Rome that prompts a comparable interdisciplinary approach to other religious dedications made by newcomers to the city from the Empire's edges and frontiers. 


\title{
Rival Powers, Rival Images: Diocletian's Palace at Split in Light of Sasanian Palace Design
}

\author{
Anne Hunnell Chen
}

It is well known that the third century AD saw intense and prolonged conflict between the Romans and their eastern neighbors, the Sasanian Persians. ${ }^{1}$ What has often remained unrecognized, however, is the Roman court's poignant use of visual media - both architectural and iconographical — to counter Sasanian claims of superiority on the world stage in this period. ${ }^{2}$ In particular, a significant parallel between the ideologically charged palatial spaces built in the two realms has remained overlooked due in large part to our conditioned way of viewing the fortified imperial palaces that began to appear in the eastern part of the Roman Empire in the late third century.

Entrenched ideas about one of the touchstone monuments of the late Roman period, Diocletian's palace at Split, located on the modern Croatian coast, have shaped the discussion of comparable, contemporary imperial residences discovered in the last forty years at Šarkamen and Gamzigrad in eastern Serbia. For this reason, a fresh look at Diocletian's palace, informed by new archaeological data and a theoretical approach sensitive to inter- and transcultural perspectives, is necessary. Consideration of the Split residence with reference to comparanda both inside and outside the Roman Empire reveals that the design choices made in Roman palaces from the late third and early fourth centuries AD were part of a concerted effort on the part of late Roman

1 Matthew P. Canepa, The Two Eyes of the Earth: Art and Ritual of Kingship Between Rome and Sasanian Iran (Berkeley, 2009); Jan Willem Drijvers, "Rome and the Sasanid Empire: Confrontation and Coexistence," in A Companion to Late Antiquity, eds. Philip Rousseau and Jutta Raithel (Chichester, 2009), 441-454; Beate Dignas and Engelbert Winter, Rome and Persia in Late Antiquity: Neighbours and Rivals (Cambridge, Eng., 2007); Alice Landskron, Parther und Sasaniden: das Bild der Orientalen in der römischen Kaiserzeit, (Wien, 2005); A.D. Lee, Information and Frontiers: Roman Foreign Relations in Late Antiquity (Cambridge, Eng., 1993).

2 Matthew Canepa's recent volume, The Two Eyes of the Earth, is the exception, and has been foundational in the exploration of competitive cultural exchange between rival courts in the Late Roman and Byzantine Empires and the Sasanian east. 
emperors to render their power legible to an international host of officials both at home and abroad.

\section{Diocletian's Palace and Military Architecture}

The emperor Diocletian came to power in the year $284 \mathrm{AD}$. A respected military leader in the Roman offensive against the Sassanid Persians of the $280 \mathrm{os}$, Diocletian's fellow soldiers raised him to the rank of ruler following discovery of the reigning emperor's murder on the march back from the army's eastern mission. ${ }^{3}$ Diocletian is perhaps most famous, however, for his innovative decision in $293 \mathrm{AD}$ to share the responsibility of governing and protecting the vast Roman Empire along with three other colleagues, thereby initiating the unique political arrangement that modern scholars call the Tetrarchy. ${ }^{4}$

The military origins of Diocletian and his co-rulers routinely color the interpretation of all things Tetrarchic: from portrait style to architectural and iconographic choices. It is no surprise, then, that Diocletian's palace at Split, a monument deemed as emblematic of the Tetrarchic period owing no doubt to its excellent state of preservation and storied history of excavation and publication dating back to the ${ }^{17}$ th century, ${ }^{5}$ is framed in the literature first and

3 For an account of the events and chronology surrounding Diocletian's first years in power, see Alan K. Bowman, "Diocletian and the First Tetrarchy," in Cambridge Ancient History 12, eds. Alan Bowman, Averil Cameron, and Peter Garnsey (Cambridge, Eng., 2005), 69-70; John Drinkwater, "Maximinus to Diocletian and the Crisis" in Cambridge Ancient History 12, eds. Alan Bowman, Averil Cameron, and Peter Garnsey (Cambridge, Eng., 2005), 58-6o; David S. Potter, The Roman Empire at Bay, AD 180-395 (London, 2004), 280-281; Andre Chastagnol, "Maximien Hercule à Rome" in Aspects de l'antiquité tardive: Saggi di storia antica, ed. A. Chastagnol and I. Tantillo (Rome, 1994), 24; Timothy David Barnes, The New Empire of Diocletian and Constantine (Cambridge, Eng., 1982), 30-2.

4 Debate persists over whether or not the creation of a four-man division of power was part of a mastermind plan for governmental administration put into place in a gradual series of steps over a number of years, or a power-sharing solution formulated as the result of ad-hoc decisions made to solve problems that arose in the course of Diocletian's reign. For a major proponent of the former, see Frank Kolb, Diocletian und die Erste Tetrarchie: Improvisation oder Experiment in der Organisation monarchischer Herrschaft? (Berlin, 1987); Frank Kolb, "La Tétrarchie: Chronologie und Ideologie der Tetrarchie," Antiquité Tardive 3 (1995), 21-31. For the latter view, see W. Seston, Diocletian et la Tetrarchie (Paris, 1946).

5 Palladio made drawings of parts of the palace in the 16th century and Spon and Wheler gave an eyewitness account of the palace remains in the late 17th century. In the 18th century, both Farlati and Adam wrote on the Split structures. Engagement with the site accelerated in the 19th and early 2oth centuries with surveys and detailed descriptions published by Lanza, Niemann, Hebrard, Zeiller, and Bulić. For discussion of the history of research at the palace 
foremost with regard to its militaristic resemblance. Whether seen in plan from above or approached on foot via one of the complex's three gates, the use of military-inspired features in the Split palace is undeniable (Figs. 11.1-11.2).

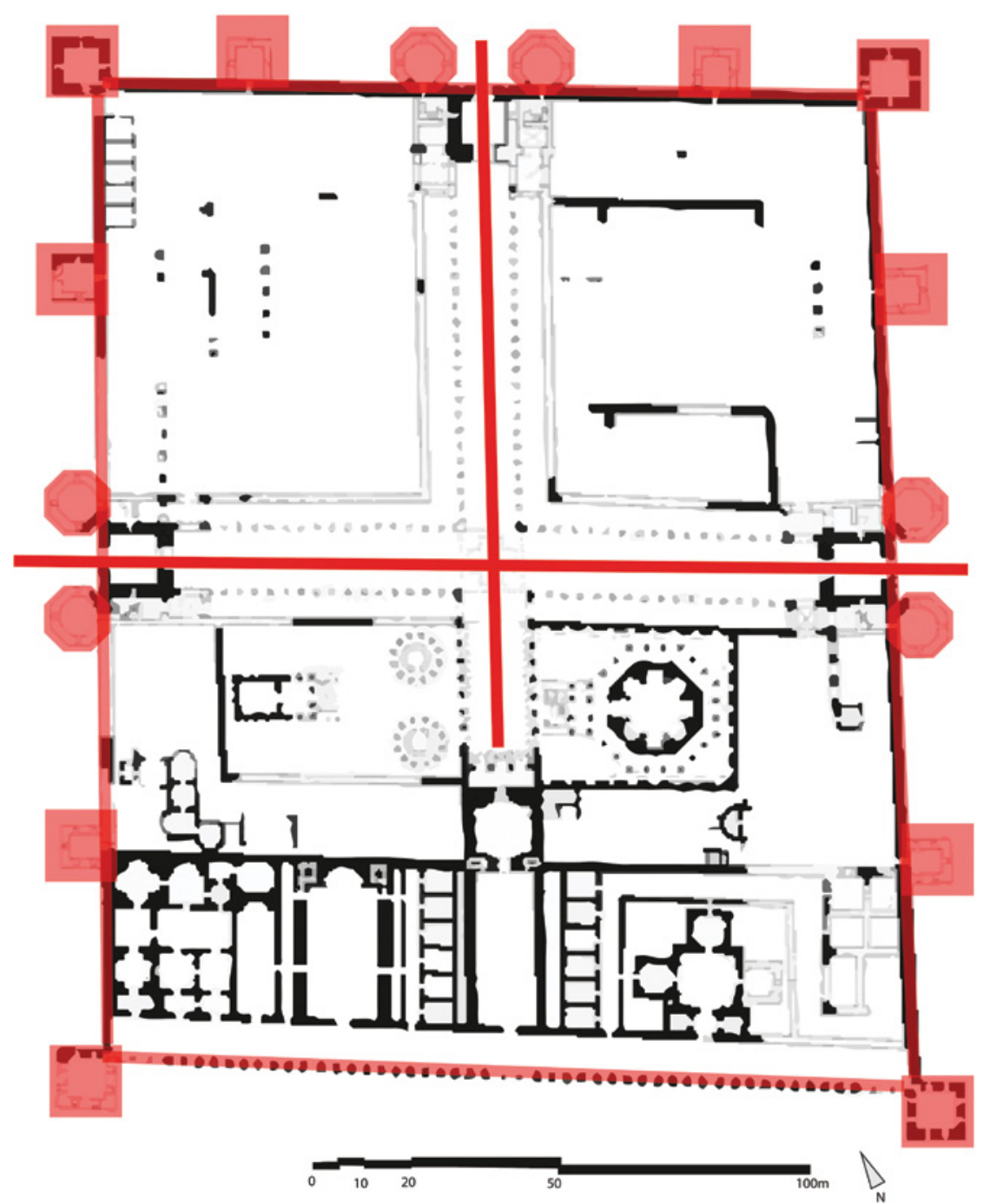

FIGURE 11.1 Plan of Diocletian's Palace at Split, highlighting the main north-south and east-west roads, towers and fortress walls.

PLAN ADAPTED FROM ĆURČIĆ, 2010.

see Tomislav Marasović, "Diciassette secoli di ricerche e restauri nel palazzo di Diocleziano a Spalato," in Diocletian, Tetrarchy and Diocletian's Palace on the 17ooth Anniversary of Existence, eds. N. Cambi, J. Belamarić, and T. Marasović (Split, 2009), 15-49. 


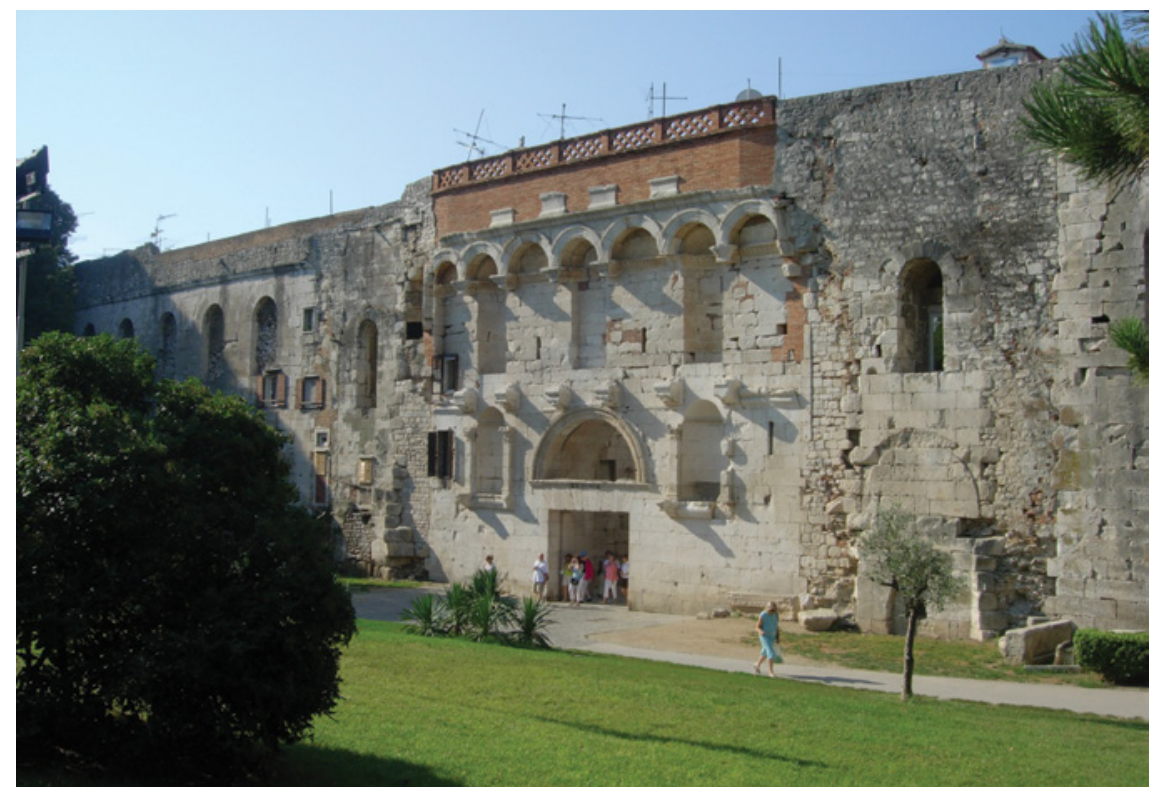

FIGURE 11.2 The North “Golden" Gate. Diocletian's palace, Split.

PHOTOGRAPH COURTESY OF SAMULI LINTULA; CREATIVE COMMONS ATTRIBUTION SHAREALIKE 3.0.

Immediately striking are the fortress-like walls punctuated with octagonal gate towers and rectangular intermediary towers that encircle the entirety of the complex. Beyond Split's curtain wall, other features of the complex likewise point to military derivation. Propugnaculi, the square rooms placed directly after the gates leading into the Split complex, served in Roman fortress design to stall besiegers in the event they breeched gate defenses. ${ }^{6}$ Inside the walls, the symmetrical organization of space around a main north-south and east-west road is yet again closely paralleled in the layouts of Roman military camps. It is precisely because Diocletian's palace adopted such features into its design that it was originally studied primarily among examples of military rather than palatial architecture. ${ }^{7}$

6 A.J. Brothers, "Diocletian's Palace at Split," Greece and Rome 19, no. 2 (1972): 185.

7 Slobodan Ćurčić, Architecture in the Balkans from Diocletian to Süleyman the Magnificent (New Haven, 2010), 26; Inge Uytterhoeven, "Housing in Late Antiquity: Thematic perspectives," in Housing in Late Antiquity. From Palaces to Shops, ed. Luke Lavan, et al. (Leiden, 2007), 34; Noël Duval, "La place de Split dans l'architecture aulique du Bas-Empire" Urbs 4 (1961), 67-95; J.J. Wilkes, Diocletian's Palace, Split: Residence of a Retired Roman Emperor (Sheffield, 1993), 69-71; R. Fellmann, "Der Diokletianspalast von Split im Rahmen der spätrömischen Militärarchitektur," Antike Welt 10 (1979), 47-55. 
Despite the inclusion of components clearly culled from the martial realm, the specifics of the palace's placement and design confirm that the complex never served an overt military function. For instance, the palace stood in a definitively non-combat zone. Placed in a quiet coastal area removed from both the troubled eastern and western fronts, the Split palace was sited on low ground although a number of higher-and thus more defensible-locales were available in the immediate vicinity. Even the towers included in the curtain wall were probably more for show than for practical use. The intermediary and corner towers at Split were rectangular, a shape no longer preferred in contemporary defensive design; by this date Roman military engineers had determined that towers with rounded profiles held more tactical advantage, especially at vulnerable corner positions. ${ }^{8}$ Recent excavations in the palace's northern sector have also yielded no sign of the barracks buildings researchers expected to find. ${ }^{9}$

It is based on the use of defensive architectural components in a predominantly non-martial structure and the site's inclusion of spaces gradated from public to private that the residence at Split is generally regarded as a hybridization of military and villa construction. This unique combination is usually chalked up to some imagined nostalgia on the part of Diocletian since he came to imperial office by way of the military ranks. ${ }^{10}$ While there is value in the

8 On military camp design and tower shapes, see James Lander, Roman Stone Fortifications. Variation and Change From the First century A.D. to the Fourth, BAR international series (Oxford, Eng. 1984), 304-5; Gregory Shelagh, Roman Military Architecture on the Eastern Frontier, 3 vols. (Amsterdam, 1995), 162-3.

9 On the excavations in the northern sector and the possible presence of a gynaeceum in this area, see K. Marasović and J. Marasović, S. Perojević, "Istrazivanja Dioklecijanove palače od 1985. do 2005. godine [The Research of Diocletian's Palace from 1985 to 2005]" in Diocletian, Tetrarchy and Diocletian's Palace on the 17ooth Anniversary of Existence, ed. N. Cambi; J. Belamarić; and T. Marasović (Split, 2009), 51-94; J. Belamarić, "Gynaeceum Iovense Dalmatiae. Aspalatho," in Diokletian und die Tetrarchie. Aspekte einer Zeitenwende, eds. Alexander Demandt, Andreas Golz, and Heinrich Schlange-Schöningen (Berlin, 2004); J. Belamarić, "The Date of Foundation and Original Function of Diocletian's Palace at Split," Hortus Artium Medievalium 9 (2003), 173-185.

10 See for instance Wolfgang Kuhoff, "Das Tetrarchische Herrschaftssystem und seine Darstellung in der Architektur: Herrscherresidenzen und Altruhesitze als Ausdruck Kaiserlicher Regierung und Repräsentation," in Diocletian, Tetrarchy and Diocletian's Palace on the 17ooth Anniversary of Existence, eds. N. Cambi, J. Belamarić, and T. Marasović (Split, 2009), 107-115; Ramsay MacMullen, Soldier and Civilian in the Later Roman Empire (Cambridge, Massachusetts, 1963), 42-6. Strzygowski's work is an exception; he recognized similarities with Roman camp design, but held that the urban planning of such eastern Roman cities as Antioch and Phillipopolis impacted the ultimate design for 
military comparisons, focus on the site's martial parallels has long dominated our viewing and, consequently, shaped our understanding of the palace.

\section{$2 \quad$ Fortified Palaces at Gamzigrad and Šarkamen}

The recent identification of a contemporary palace, also located on the Balkan Peninsula and belonging to one of Diocletian's imperial colleagues, provides new evidence that suggests the expedience of expanding the frame of reference for these Late Roman palaces beyond the Roman borders. With the 1984 discovery of an inscription containing the topographical name 'Felix Romuliana,' (Fig. 11.3) scholars identified a fortified structure near the Serbian village of Gamzigrad as an imperial palace built by Diocletian's Tetrarchic co-ruler, Galerius (Fig. 11.4). ${ }^{11} \mathrm{~A}$ third, unfinished fortified complex near the Serbian village of Šarkamen (Fig. 11.5) that is likewise tentatively connected with yet another Tetrarch, ${ }^{12}$ points towards a trend in imperial architecture under the Tetrarchic reign.

As at Diocletian's palace, a massive military-inspired curtain wall surrounds the complex at Romuliana and showcases a series of towers designed above all to make an impression: the enormous girth of Romuliana's towers offered no defensive advantage and instead communicated the grandeur of the complex

Diocletian's palace in Split. See J. Strzygowski, "Spalato, ein Markstein der romanischen Kunst bei ihrem Ubergange vom Orient Bach dem Abendlande," in Studien aus Kunst und Geschichte; Friedrich Schneider zum siebzigsten Geburtstage gewidmet von seinen Freunden und Verehrer, ed. Joseph Saner (Freiburg im Breisgau, 1906), 323-336.

11 On the inscription, its importance for the identification of the site and the location of its original display, see Maja Živić, "Artistic Achievements in the Imperial Palace," in Felix Romuliana Gamzigrad, ed. Ivana Popović (Belgrade, 2012), 101-2; Maja Živić, Felix Romuliana 50 Years of Solving (Belgrade, 2003), 21-5 and cat. 1; Emanuel Mayer, Rom ist dort, wo der Kaiser ist. Untersuchungen zu den Staatsdenkmälern des dezentralisierten Reiches von Diocletian bis zu Theodosius II (Mainz, 2002), 80-90; Dragoslav Srejović, Petar Petrović, and Veselin Kostić, Roman Imperial Towns and Palaces in Serbia (Belgrade, 1993), 49, 204-5, cat. 48.

12 The Šarkamen complex is attributed to Maximinus Daia based on its similarity with the palace of Galerius at Romuliana, his familial connection to the region (for sources, see Barnes, New Empire: 39), the fragments of a large-scale seated porphyry statue (comparable to the seated statue of a Tetrarch from the Greco Roman Museum of Alexandria, inv. \#5954), and the presence of gold plaques with the impressions of Tetrarchic imperial portraits taken from coins. The most recent overview of the site published in English is Miodrag Tomović, et al, Šarkamen. A Tetrarchic Imperial Palace, The Memorial Complex (Belgrade, 2005). 


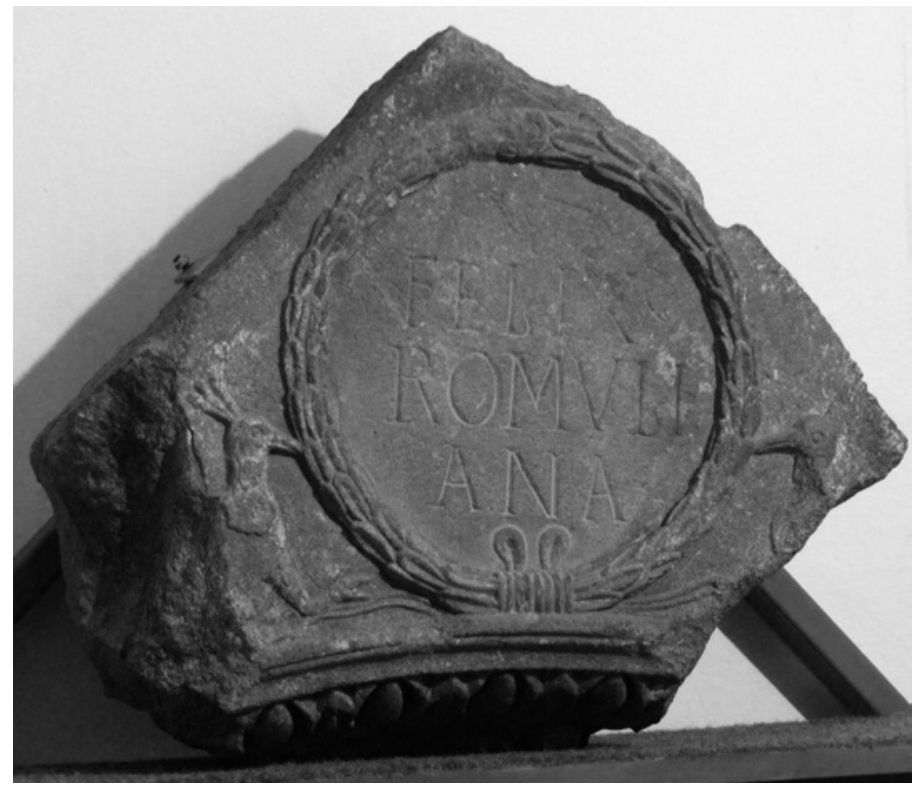

FIGURE 11.3 "Felix Romuliana" inscription excavated at the Late Roman palace near Gamzigrad, Serbia.

PHOTOGRAPH COURTESY OF THE NATIONAL MUSEUM, ZAJEČAR.

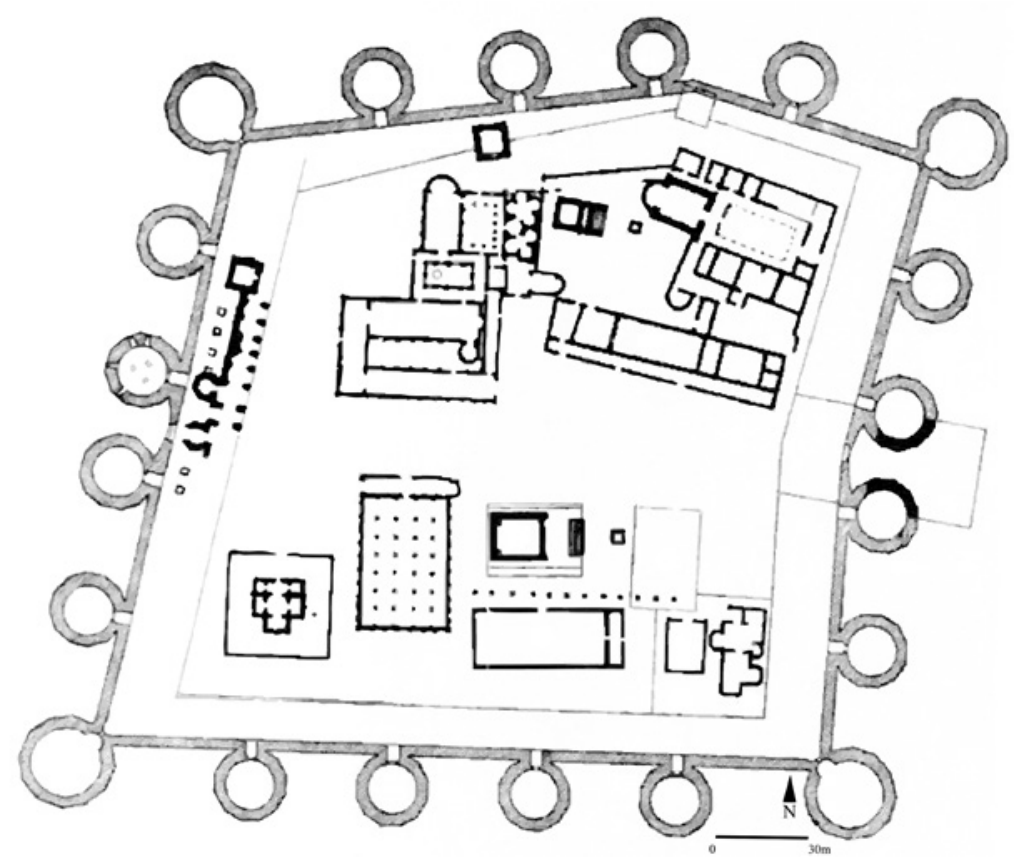

FIGURE 11.4 Plan of the Late Roman palace near Gamzigrad, Serbia. PLAN ADAPTED FROM ĆURČIĆ, 2010. 


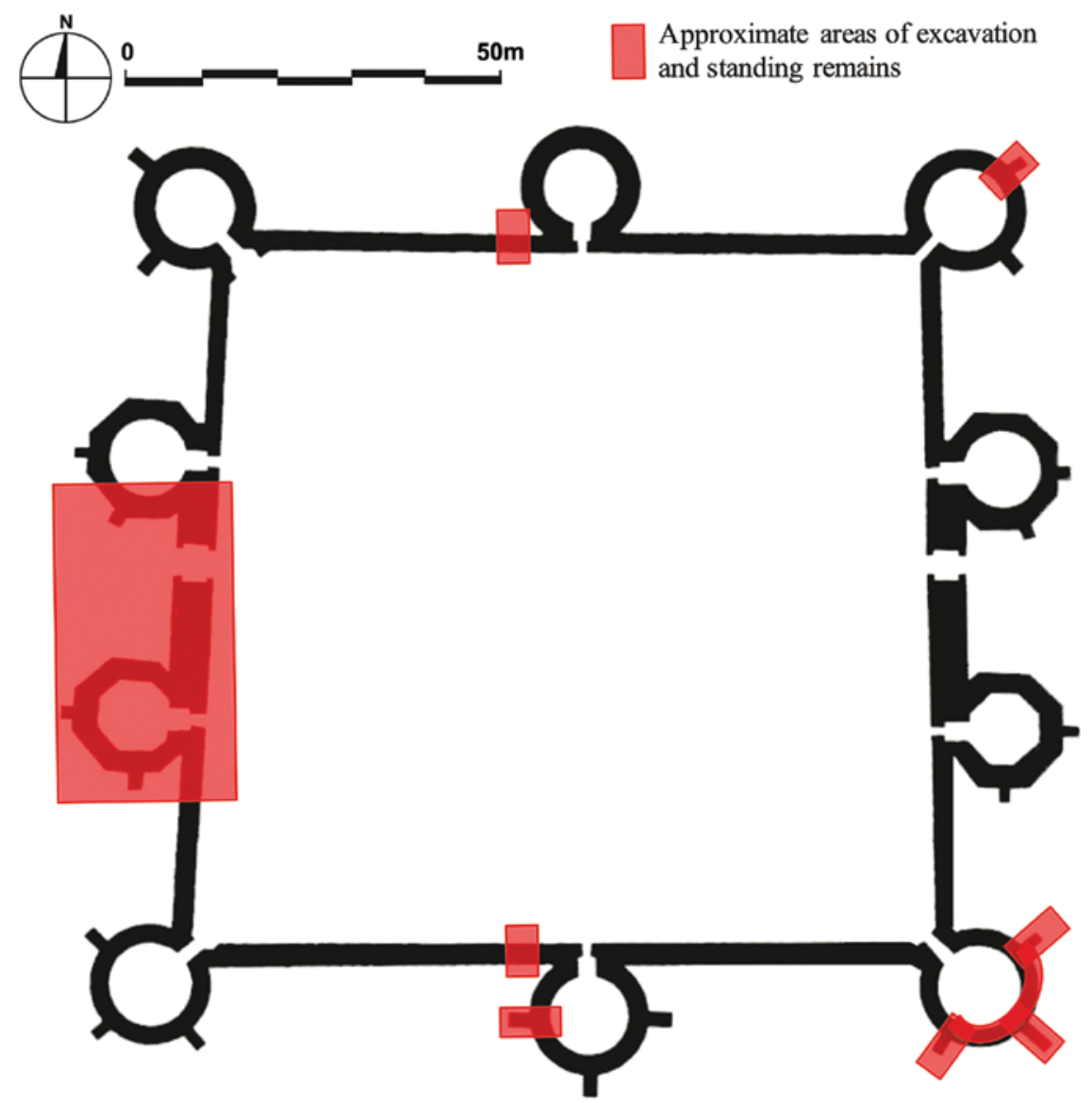

FIGURE 11.5 Plan of the unfinished curtain wall from the Late Roman complex discovered near the village of Šarkamen in eastern Serbia.

PLAN ADAPTED FROM ĆURČIĆ, 2010.

they screened. ${ }^{13}$ Likewise comparable is the physical positioning of the two palaces-like at Split, the palace at Romuliana is removed from barbarian threat and situated on low ground despite the proximate availability of more defensible alternatives.

Prior to the period of the Tetrarchy, the idea of placing an imperial residence within massive fortifications was unprecedented in Roman architecture. The archetypal Roman palace, the Palatine complex in Rome, was designed to

13 The intermediate towers at Romuliana measure approximately 25 meters in diameter; those at the fortification's corners measure approximately 30 meters in diameter. Ćurčić, Architecture in the Balkans, 24. 
maintain the fiction of the emperor's accessibility to his subjects. Its central location, intimate connection with the Circus Maximus, incorporation of public sanctuaries, and eschewal of its own separatist fortification wall all worked toward a publically inclusive effect. In contrast, Split and Romuliana, with their rural locations, monumental walls, and lack of entertainment venues for the benefit of the greater public such as theaters, amphitheaters, or circuses, visually communicated the restriction of access to the emperor. ${ }^{14}$ As such, the Palatine clearly does not stand as the primary conceptual reference point for the fortified palaces of the late third century. The Hellenistic precedents upon which the Palatine drew likewise turn up empty in this regard. Palaces at Vergina, Pella, Alexandria, and Pergamon share the characteristic that they are designed to communicate a degree of pubic inclusiveness given their incorporation of sanctuaries and entertainment venues. Even those palaces of the Hellenistic period that featured fortress walls as part of their design, such as the Hellenistically inspired Thracian palace at Seuthopolis, or the Attalid palace at Pergamon, differ from the Roman palaces of the third century AD in that the fortifications at such sites, given their location in disputed territories, served a definite defensive purpose in contrast to the more symbolically motivated defensive systems at the Tetrarchic structures. Moreover, it is significant that although the Romans no doubt knew the residence at Peragmon, they chose not to incorporate fortifications into their palace design until a full five centuries after the foundation of the Attalid royal residence. The lack of directly comparable Roman or Hellenistic precedents has therefore set the task of determining what prompted this noticeable shift in imperial architectural design under the Tetrarchy. There must have been some motivating factor at this particular historical moment to prompt a break from three centuries worth of Roman precedents (and preceding generations of Hellenistic exempla upon which they drew) with regard to royal palace design. It is to this end that the 'military nostalgia' interpretation has been deployed.

However, archaeological finds from Romuliana weighed together with the potential for bi-directionality in cultural influence between Rome and her eastern rivals that scholars such as Matthew Canepa and Lynne Lancaster have recently illustrated, ${ }^{15}$ may suggest another route of inquiry for the Roman fortified palaces. Among the finds from Romuliana's ongoing excavations are bricks stamped in the name of the fifth Macedonian legion, a unit whose presence is

\footnotetext{
14 Ibid., 32-6.

15 Canepa, Two Eyes of the Earth; Lynne Lancaster, "Parthian Influence on Vaulting in Roman Greece? An Inquiry into Technological Exchange Under Hadrian," American Journal of Archaeology 114, no. 3 (2010), 447-472.
} 


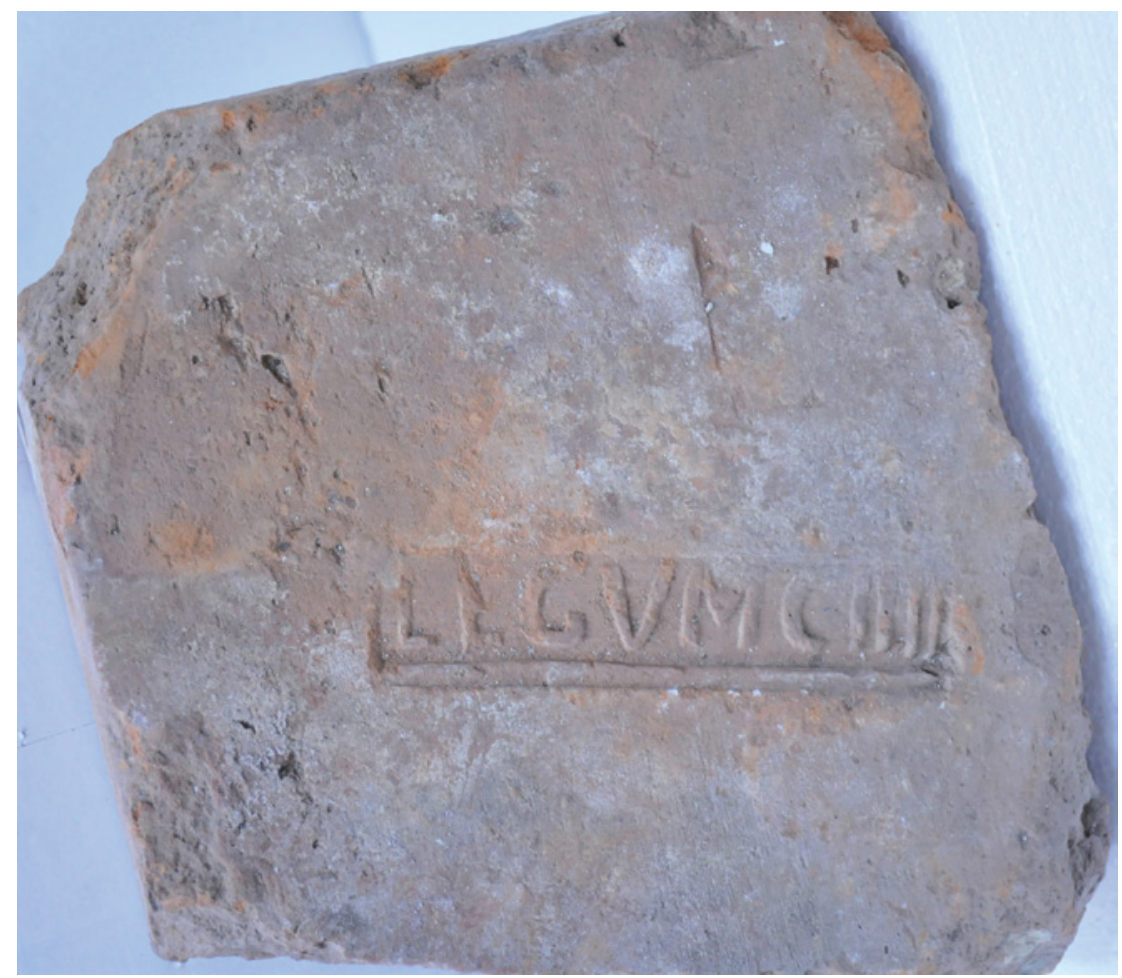

FIGURE 11.6 Brick stamped in the name of the Fifth Macedonian legion. From the Late Roman palace near Gamzigrad, Serbia.

PHOTOGRAPH COURTESY OF THE NATIONAL MUSEUM, ZAJEČAR.

attested deep in the territory of the Persian Sasanids in the years directly preceding the palace's construction (Fig. 11.6). These stamps offer a terminus post quem of winter 298/299 AD, the date at which hostilities with the Sasanians were concluded, and imply that this legion, newly returned home with exposure to a world beyond the eastern borders of the Roman Empire, participated in the construction of Galerius' palace. ${ }^{16}$ The involvement of this legion also implies that the construction of the palace did not begin until the emperor Galerius - who himself commanded the legions on the Sasanian campaignreturned victorious to Roman territory after a martial tour in Persia.

16 M. Čanak-Medić, Gamzigrad: Kasnoantička palata: arhitektura i prostorni sklop [Gamzigrad: Late Antique Palace: Architecture and Spatial Organization] (Belgrade, 1978), 227; Maja Živić, “The Eternal Palace of Galerius," Minerva 18, no. 2 (2007), 32. 
The Romuliana brick stamps call our attention to some unrecognized historical parallels regarding the construction of Diocletian and Galerius' palaces that may in turn recommend comparison between the Tetrarchic fortified palaces and the Sasanian imperial residences in the east. Although confirmation of the exact dates of construction will have to await further archaeological work at both Split and Romuliana, clues from contemporary written sources, archaeology, iconography, and architecture suggest that both sites date relatively late in the collective reign of Diocletian and his colleagues. ${ }^{17}$ That is, it is probable that the construction of both palaces dates to after the decisive Roman defeat of the Sasanians that led to the Treaty of Nisibis of $299 \mathrm{AD}$, an armistice heavily favoring the Romans that prevented further major hostilities between the two empires until the mid fourth century. ${ }^{18}$

Similarly intriguing is the fact that three of the Tetrarchic colleaguesincluding the two who built the residences at Split and Romuliana-were at various times on Persian soil and even in the vicinity of the Sasanian capital city of Ctesiphon. Diocletian and Maximian participated in the capture of Ctesiphon in the 280 s, and Galerius advanced on the same city while successfully campaigning against the Persians in the late $290 .^{19}$ It is certain that the Sasanian capital city contained a palace in the third century, but because the extraordinary remains of its sixth-century successor occupy the site today, its exact characteristics have yet to be archaeologically determined. ${ }^{20}$

17 On the date of Romuliana see Živić "Artistic Achievements"; Živić, Felix Romuliana, 10-45; Mayer, Rom ist dort, 80-90. On the date of the palace at Split, see most recently G. Nikšić, "Diocletian's Palace—Design and Construction," in Bruckneudorf und Gamzigrad: spätantike Paläste und Großvillen im Donau-Balkan-Raum, ed. Gerda v. Bülow und Heinrich Zabehlicky (Bonn, 2011), 187-202.

18 The main primary source on the Treaty of Nisibis is Peter the Patrician, fragments 13-14. For a summary of other sources on the treaty, see Engelbert Winter, Die Sāsānidischrömischen Friedensverträge des 3. Jahrhunderts n. Chr. ein Beitrag zum Verständnis der aussen politischen Beziehungen zwischen den beiden Grossmächten (Frankfurt am Main, 1988), 169-71. For general discussion of the Treaty of Nisibis and its terms, see R.N. Frye, "The Political History of Iran Under the Sasanians," in The Cambridge History of Iran. The Seleucid, Parthian and Sasanian Periods, ed. Ehsan Yarshater (Cambridge, 2000), 130-1; Dignas and Winter, Rome and Persia, 122-31.

19 For a summary of the military careers of Diocletian, Maximian, and Galerius, see Barnes, New Empire, 30-8.

20 Most scholars now agree on the sixth-century date of the palace today standing at the site of ancient Ctesiphon, but some originally believed the building to date to the reign of Shapur I in the third century; see Remy Boucharlat, "Larchitecture sassanide," in Les Perses sassanides: Fastes d'un empire oublié (224-642), ed. F. Demange (Paris, 2006), 46-50; 
A sole early third-century relief that preserves a representation of the Ctesiphon palace is the only evidence for the appearance of the structure the Tetrarchic emperors would have seen while on campaign in the city. ${ }^{21}$ Fortunately, early Sasanian palaces subscribed to a rather standardized model of organization and construction. Other third-century Sasanian palaces and the Parthian predecessors on which they drew remain extant, and thus allow for comparisons with the Roman west. Taking into account that fortified palaces only came into existence in the eastern Roman provinces under emperors who had themselves campaigned in Persia and after the most decisive Roman victory of the century against their Sasanian nemesis, it is worth considering that Persian palatial architecture was one among a medley of elements that influenced the design of the palaces built under the Tetrarchy.

This is, of course, not to discount Hellenistic and Roman influences altogether. Much of the architectural vocabulary used in the Tetrarchic palaces is overtly Roman, as the columnar orders bear witness, and as already acknowledged, inspirations from military camp design played a part in the formal appearance of these palaces. Rather, the point is to enrich the narrative by exposing additional realms from which these late Roman rulers may have drawn inspiration, and to offer productive ideas beyond the 'military nostalgia' explanation to account for the sudden appearance of fortified imperial residences in non-combat areas under Diocletian and his colleagues. Inge Nielson has stressed in recent research highlighting the hybrid Macedonian, Egyptian, and Achaemenid roots of Hellenistic palaces, that "eastern models for palaces ... are typically overlooked in favor of Greek models." ${ }^{22}$ In an effort to avoid such bias with respect to Roman palaces, comparison with contemporary Persian palace architecture is in order, particularly given Roman tendency toward eclectic appropriation even from those they considered enemies (a point discussed further below), the close contact with the Persians at the time the Tetrarchic palaces appeared, and the enormous time-gap between the construction of the most comparable of the Hellenistic palaces and the residences at Split, Romuliana, and Šarkamen.

D. Huff, "Architecture sassanide," in Splendeur des Sassanides. L'empire perse entre Rome et la Chine, 224-642 (Brussels, 1993), 45-61. For a discussion of the dating, see Edward J. Keall, "Ayvan-e Kesra" in Enclopaedia Iranica vol. 3 (1987), 155-159.

21 Richard Brilliant, The Arch of Septimius Severus in the Roman Forum (Rome, 1967), 214-5.

22 Inge Nielsen, Hellenistic Palaces: Tradition and Renewal (Aarhus, 1994), 99. See also Inge Nielson (ed.), The Royal Palace Institution in the First Millenium BC: Regional Development and Cultural Interchange Between East and West (Athens, 2001). 


\section{Sasanian Palace Design and Spatial Organization at Split}

It turns out that the practice of situating imperial palaces within impressive fortification walls at a remove from cities-while without precursors in the Roman Empire-was a feature of early Sasanian architectural tradition that was itself likely inspired by preceding Parthian practices. Fortified palaces predating those constructed under the Tetrarchs in the eastern Roman Empire are known in the Parthian palace at Old Nisa and the Sasanian palace Qal'a-ye Doktar. ${ }^{23}$ What is more, in the case of the palace at Old Nisa excavators have yet to find any indication that the palace's fortifications served any real defensive, military function. Instead, the curtain walls surrounding the site were constructed for primarily symbolic and aesthetic reasons. ${ }^{24}$ This suggests that not only was the idea to hem a palace inside military-inspired walls already extant in the Near East before the Tetrarchic rise to power, but so too was the concept of using such walls primarily as symbolic statements of power rather than defensive features - a state of affairs thus comparable with the later Roman manifestations at Split, Romuliana, and Šarkamen, and in stark contrast to those much earlier militaristically motivated western examples at sites such as Seuthopolis.

Looking to the palace at Split with this new possibility in mind, a comparison between the spatial organization of Diocletian's palace and the recurring layout that is a defining feature of Sasanian palaces reveals surprising conceptual similarities (Fig. 11.7).

23 For the Parthian palace of Old Nisa see, A. Invernizzi "New Archaeological Research in Old Nisa," in The Art and Archaeology of Ancient Persia: New Light on the Parthian and Sasanian Empires, eds. Robert Hillenbrand, V.S. Curtis, and J.M. Rogers (London, 1998), 8; Dietrich Huff, "Formation and Ideology of the Sasanian State in the Context of Archaeological Evidence," in The Sasanian Era, eds. V.S. Curtis and S. Stewart (New York, 2008), 41-2. For the palace of Ardashir I at Qala-ye Doktar, Firuzabad, see Dietrich Huff and Philippe Gignoux, "Ausgrabungen auf Qal'a-ye Dukhtar bei Firuzabad 1976," Archäologische Mitteilungen aus Iran, Neue Folge 11 (1978); Dietrich Huff, "Qala-ye Dukhtar bei Firuzabad: Ein Beitrag zur sasanidischen Palastarchitektur,"Archäologische Mitteilungen aus Iran, 4 (1971); Dietrich Huff, "Formation and Ideology," 42-4; Dietrich Huff, "Qal'a-ye Doktar," Encyclopaedia Iranica (2006), <http://www.iranicaonline.org/articles/qala-ye-doktar>; Dietrich Huff, "Architecture sassanide," 50-3; Dietrich Huff, "Architecture III: Sasanian Periods," in Encyclopaedia Iranica vol. 2 (1986), 329-334; Dorothy Shepherd, "Sasanian Art," in The Cambridge History of Iran. The Seleucid, Parthian and Sasanian Periods, ed. Ehsan Yarshater (Cambridge, 1983), 1058-9.

24 Invernizzi "New Archaeological Research in Old Nisa," 8. 


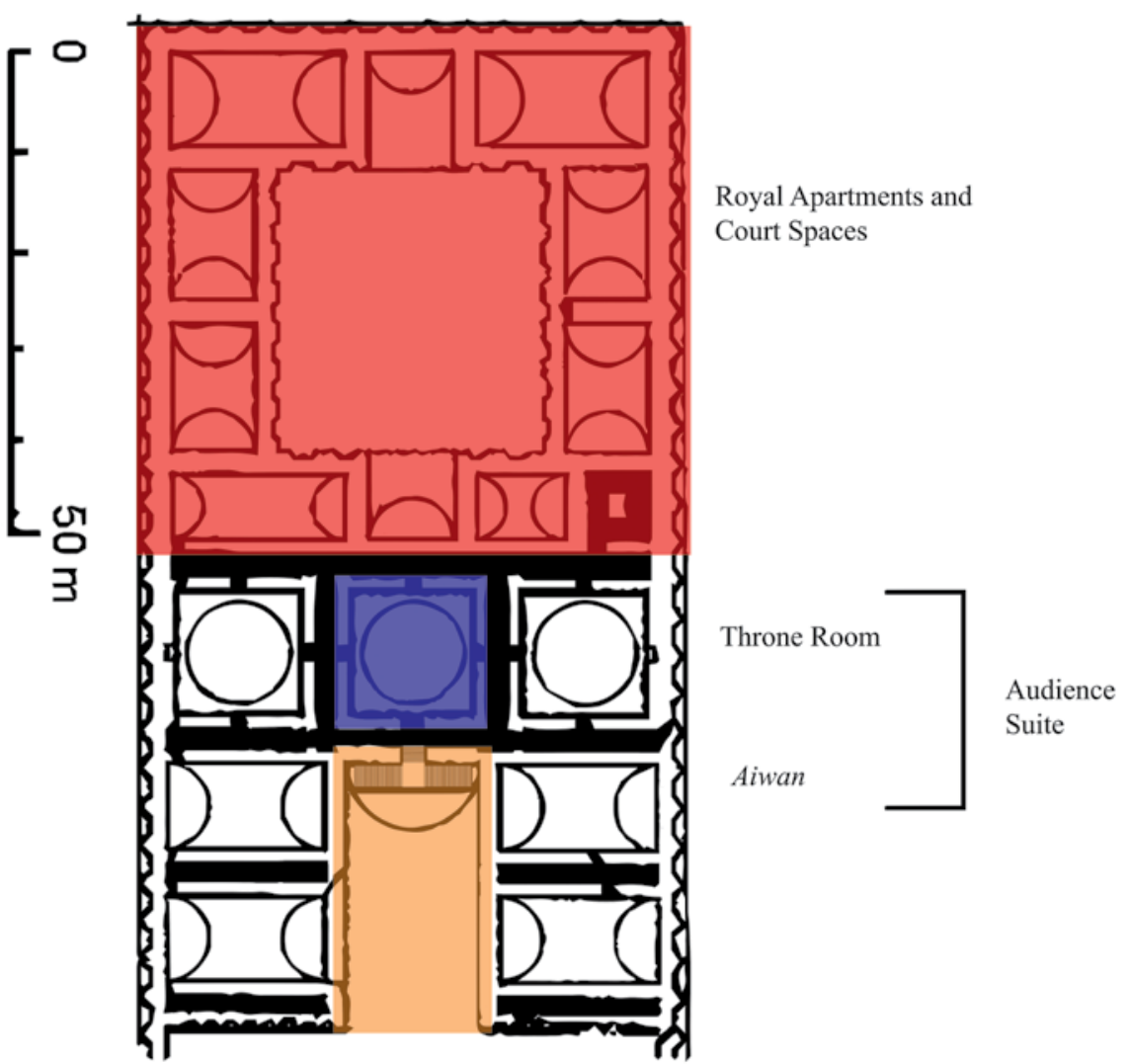

FIGURE 11.7 Plan of the palace of Ardashir I at Firuzabad. Early third c. AD. Demonstrating the organizational layout that became characteristic of early Sasanian palaces. PLAN ADAPTED FROM HUFF 2008.

The palaces of the Sasanian kings were symmetrically and axially conceived, and customarily incorporated a core sequence of rooms arranged along the main axis of the building. This core consisted of a suite of rooms for royal audiences, and a two-story area composed of court spaces on the ground floor and private royal apartments on the upper level. The audience suite preceded the more intimate two-story complex and was made up of an expansive gathering hall with a vaulted ceiling used to house those waiting for an audience, a room known as an aiwan, and an adjoining square room with a domed roof, which served as the throne room (Fig. 11.8). This layout was first formulated in the palaces of Ardashir I from the early part of the third century and became the prototypical configuration for all early Sasanian palaces. ${ }^{25}$

25 Huff, "Qala-ye Dukhtar" p. 127; Huff and Gignoux, "Ausgrabungen auf Qala-ye Dukhtar," 117; Dietrich Huff, "Firuzabad," in Encyclopaedia Iranica vol. 9 (1999, 633-636); Shepherd, 


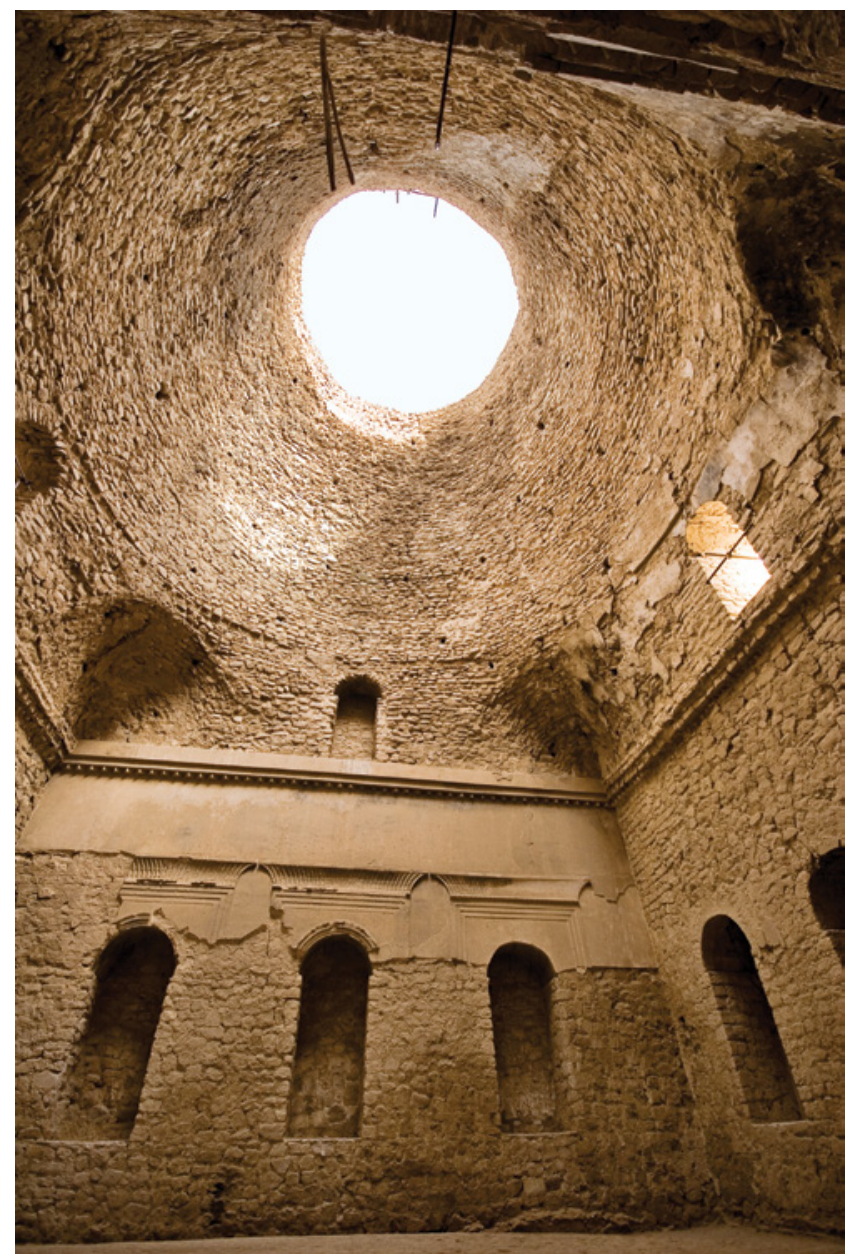

FIGURE 11.8 Throne room at the palace of Ardashir I, Firuzabad. Square room with a domed roof executed in pitched courses of mudbrick.

PHOTOGRAPH COURTESY OF ALI MAJDFAR.

A similar spatial composition is evident at Split (Fig. 11.9). Arranged along the central axis of the southern sector is a progression of spaces associated with royal audiences that serves to preface the more intimate spaces contained in the two-level complex behind. After passing through the tetrapylon located at the crossing of the palace's two main thoroughfares, a visitor would enter a large, slightly sunken, peristyle. Located directly opposite the peristyle

"Sasanian Art," 1058-9; Huff, "Formation and Ideology," 42-4; Huff, "Architecture III: Sasanian Periods." 
entrance from the tetrapylon, the imposing architecture of the protyron, with its temple facade-like appearance and elevated position, dominated the peristyle (Figs. 11.9-11.10). Although not vaulted like the aiwan, the peristyle is believed to have served as a gathering and waiting area for those seeking audience with the emperor, just like its Persian counterpart. ${ }^{26}$

At a level elevated above the peristyle and located directly behind the protyron stands a room with a square footprint enclosed by a brick domed ceiling (Figs. 11.9 and 11.11). The room's function may never be definitively known, but the prominence of its location, the technical complexity of the room shape and its dome mosaic, which was executed with extensive use of expensive

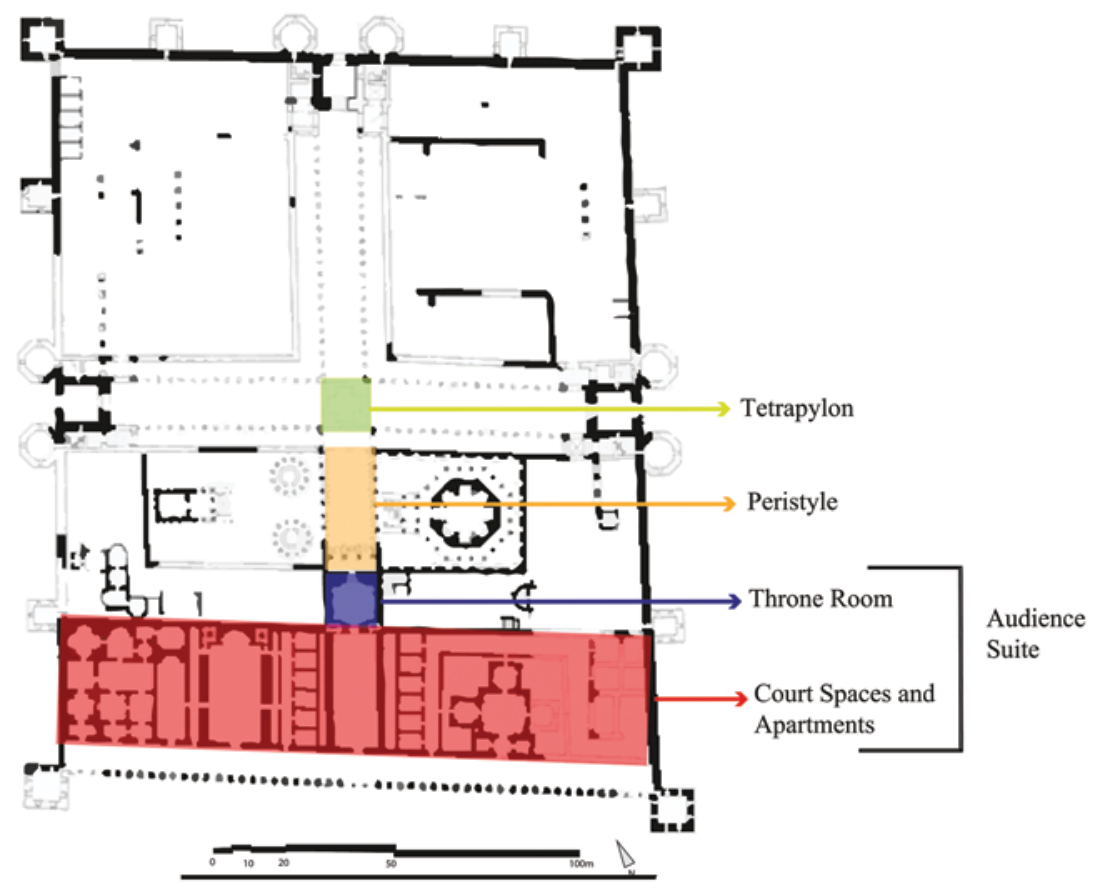

FIGURE 11.9 Plan of Diocletian's palace, Split.

PLAN ADAPTED FROM ĆURČIĆ, 2010.

26 Written sources confirm that important residences including the Palatine were fronted by open-air vestibules intended for use by those awaiting formal admission to the residence; on this point, see Birgitta Tamm, Auditorium and Palatium. A Study on Assembly-Rooms in Roman Palaces During the 1st century B.C. and the 1st century A.D. (Stockholm, 1963), 91-108. The protyron and peristyle probably also played a role in staged court ceremonies, such as at functions related to the emperor's appearances and departures. On this and the peristyle's role as an open-air “waiting room”, see Ćurčić, Architecture in the Balkans, 36. 


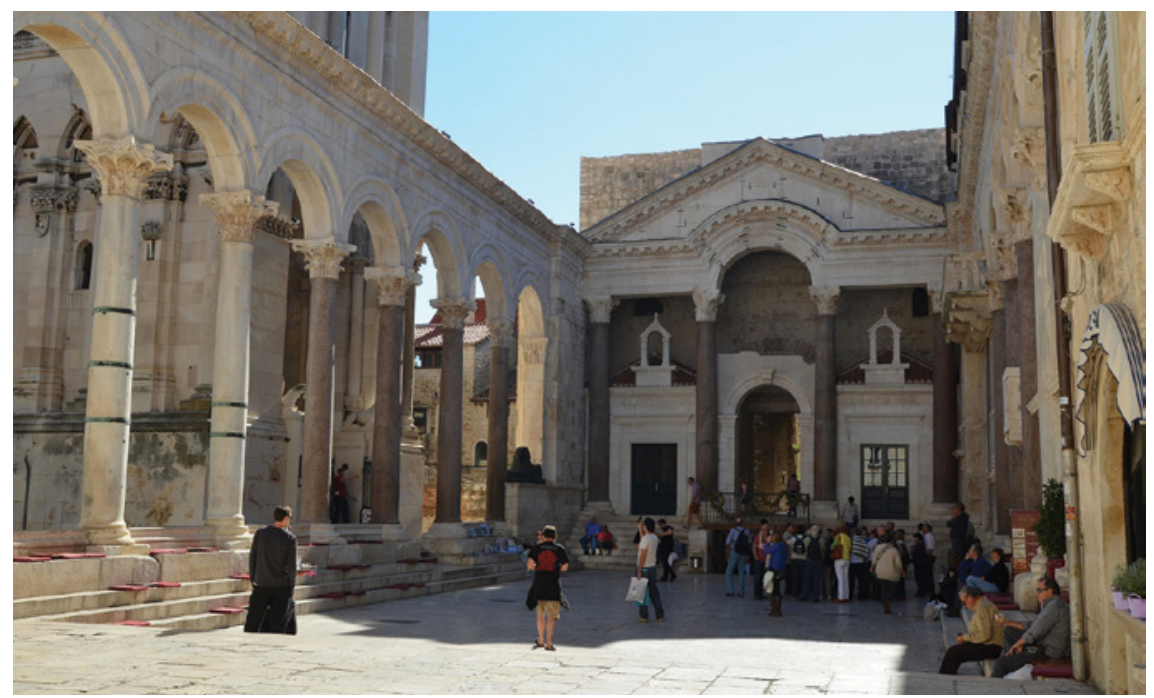

FIGURE 11.10 View through the sunken peristyle to the protyron. Diocletian's palace, Split. PHOTOGRAPH COURTESY OF CAROLE RADDATO, VIA WIKIMEDIA COMMONS/CC-BY-SA.

gold tesserae, ${ }^{27}$ has led to the belief that the room served as a salutatorium or throne room. ${ }^{28}$ If this was indeed the function of the gold-domed room, then there is functional as well as architectural similarity between the rooms on the central axis at Split and those in the Sasanian palaces: both included a vestibule-throne room suite located on the palace's central axis; in both cases that suite provided exclusionary access into the court spaces and royal apartments located beyond in an adjoining two-story complex; and in both cases the throne room consisted architecturally of a square room covered by a brick dome. This last feature is particularly important, given that such a room shape had never before been incorporated into a Roman palace at such a scale and in such a prominent position, although, as stated above, it played a central role as the characteristic shape of the throne room in Sasanian palace design.

Although it is accepted among Sasanian scholars that the imperial residences of the Sasanids were characterized by the proscribed, repetitive plan

27 In fact, this is one of the earliest examples of the use of mosaic on vaults, a decorative feature that would gain particular prominence under the Byzantines; see L. Karaman and F. Bulić, Palača cara Dioklecijana u Splitu [The Palace of Emperor Diocletian at Split] (Zagreb, 1927), 103; Ćurčić, Architecture in the Balkans, 37.

28 Karaman and Bulić, Palača Cara Dioklecijana, 168-70; Ćurčić, Architecture in the Balkans, 37 with previous literature n. 45 . 


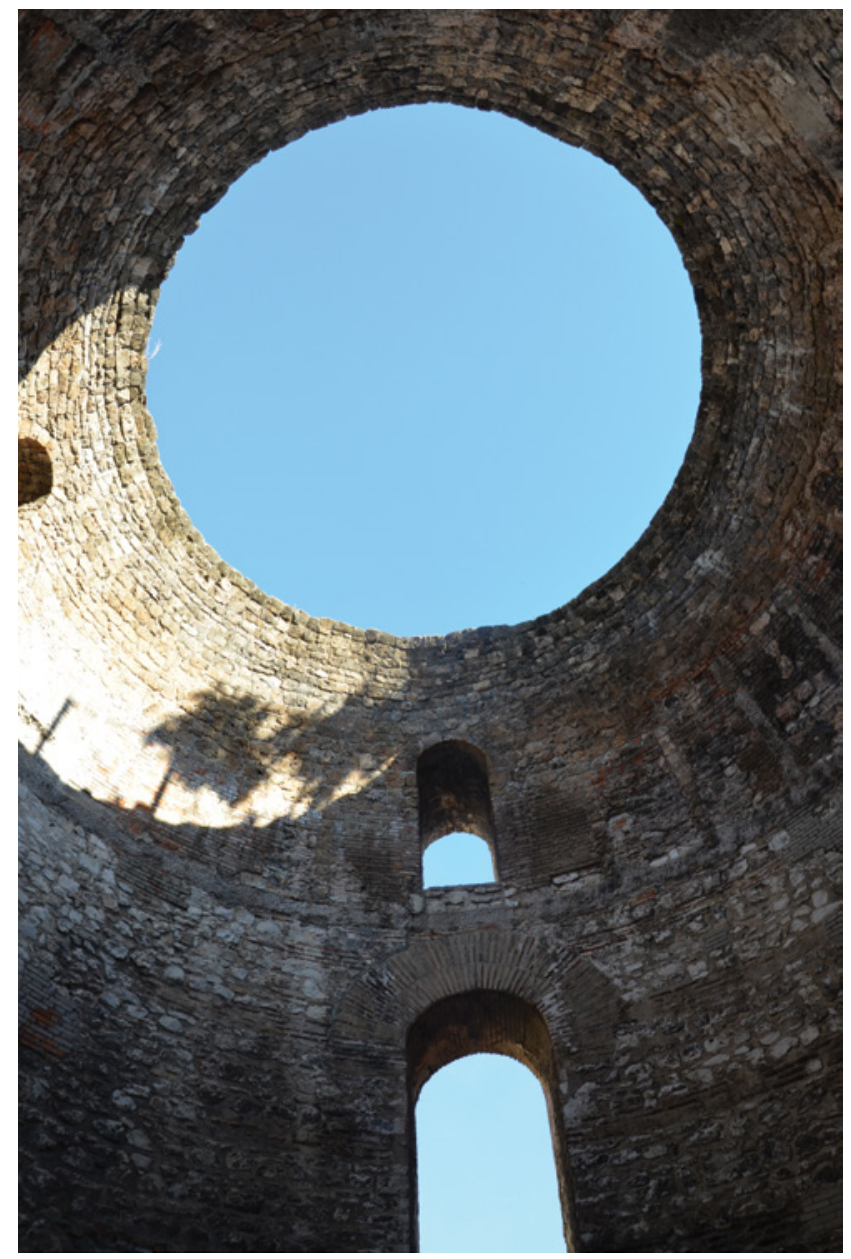

FIGURE 11.11 Domed roof of the 'Throne Room,'Diocletian's palace, Split. Executed in pitched brick technique. PHOTOGRAPH COURTESY OF CAROLE RADDATO, VIA WIKIMEDIA COMMONS/CC-BY-SA.

described for comparative purposes above, this conclusion is based on analysis of early third-century palaces still extant deep within the Sasanian homeland of Persis and the later, sixth-century manifestation of the Ctesiphon palace built atop that city's earlier predecessor. Objection could therefore conceivably be launched against the proposition offered here on the grounds that there is no direct evidence that the Ctesiphon palace of the third century (the palace we are certain members of the Tetrarchy encountered) conformed to the layout now considered characteristic of Sasanian palace structures. It is in this regard 


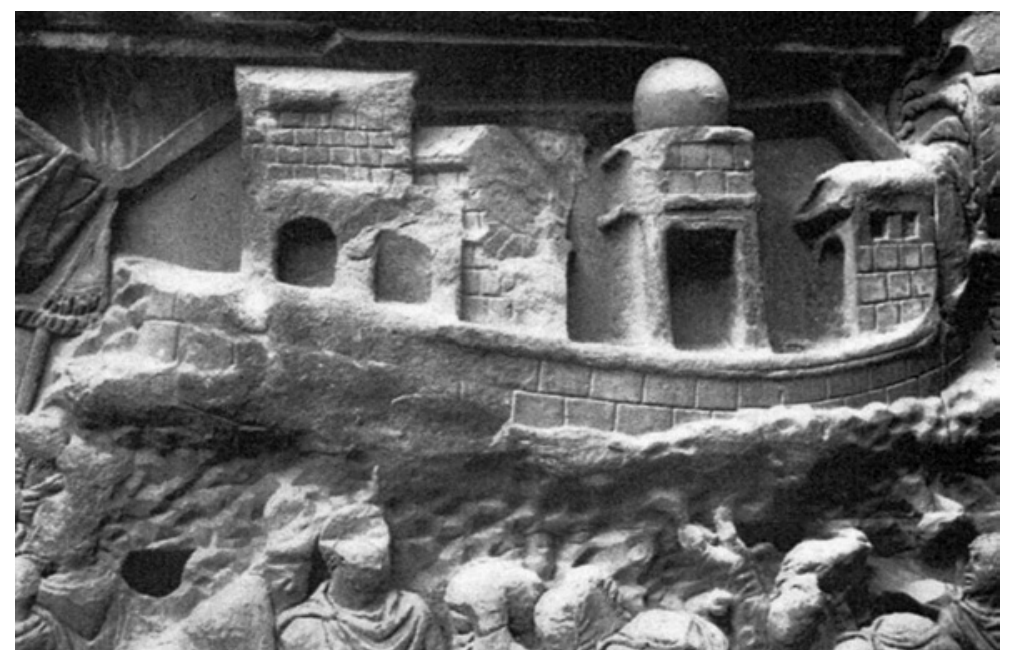

FIGURE 11.12 Depiction of the palace at Ctesiphon. From the so-called Great Historical Panel IV on the southwest side of the Arch of Septimius Severus, Rome. Early third century. After Brilliant 1967, pl. 91 . REPRODUCTION COURTESY OF THE AMERICAN ACADEMY IN ROME.

that the relief representation of the Ctesiphon imperial residence-alluded to above—becomes particularly important (Fig. 11.12). ${ }^{29}$

Appearing on a triumphal monument in Rome as part of a narrative scene depicting Septimius Severus' early third-century capture of Ctesiphon, this summary depiction of the eastern monarch's palace was not intended as a detailed study of the structure. Significant for our purposes are the elements of the structure that are given emphasis in the image as a means of communicating the structure's identity to the Roman audience. Particularly emphasized in this otherwise nonspecific depiction is the walled enclosure that marks off the palace's component buildings, ${ }^{30}$ and, among the cluster of structures

29 This depiction of the palace appears on the southwest so-called "Great Historical Panel IV" of the Arch of Septimius Severus, still standing today in Rome and dated to the early third century. The arch's reliefs summarize Severus' successful campaigns in the east, with panel IV devoted to recounting the Roman army's capture of the capital city, Ctesiphon, which included the looting of the city's imperial palace. For description and discussion of the events and structures depicted in panel IV, see Brilliant, Arch of Septimius Severus, 181-2, 208-17.

30 Significantly, this enclosure wall is not crenelated. In the scene depicted just below on the same panel, the city wall of Ctesiphon is represented with prominent crenelations. The absence of this detail thus differentiates the fortification surrounding the palace from 
inside the enclosure, a building that is carefully distinguished from the others by its conspicuous combination of square footprint and domed roof. The relief image therefore suggests that the palace the Tetrarchs encountered in Ctesiphon exhibited the same distinctive characteristics as the archaeologically investigated Sasanian palaces from Persis used as comparative material in the preceding discussion. ${ }^{31}$

The Roman relief is not only valuable as evidence for the Ctesiphon palace's historical appearance. Conveniently, it is also an indication of what-for a Roman mind-was distinctive in an eastern palace. Schematic architectural rendering depends on the selective depiction of those features the audience is likely to deem a structure's most characteristic elements. The Roman artist's choice to emphasize the very two features that have been identified above as inspirational in the design of Diocletian's palace - that is, the fortification wall and the rectilinear building covered with a dome- suggests that the Tetrarchs knew what they were doing in introducing such elements into their palaces.

The possibility of architectural inspiration derived from the Persian east becomes even more attractive when one considers that the Tetrarchic palaces in the eastern Roman Empire incorporated eastern-inspired constructional techniques and iconographic details previously unattested in the west. The technique used to construct the brick domes mentioned above probably came to the Roman Empire from the east. Domed ceilings constructed entirely out of brick and without the use of centering were unprecedented in Roman imperial architecture prior to the late third century, but were known in Mesopotamia as early as the third millennium вс. ${ }^{32}$ The ubiquity in the east of material

Ctesiphon's city wall and is meant as a signal to the viewer that the group of buildings depicted inside the un-crenelated enclosure is a distinct feature, not another depiction of the city itself. On this point see ibid., 214-5.

31 There is good reason to think that the reliefs on the arch translated into stone (or drew heavily from) the history paintings carried as part of the triumph that followed Septimius Severus' eastern victories. The narrative paintings may have been executed by artists who had been present on the campaigns, thus it is possible the depiction of the palace was based on an eyewitness rendering of the structure. On the reliefs as based on historical paintings, see Susann Lusnia, "Battle Imagery and Politics on the Severan Arch in the Roman Forum," in Representations of War in Ancient Rome, ed. S. Dillon and K. Welch (Cambridge, Eng., 2006). On the spectacle of the Roman triumphal procession and the historical paintings carried therein, see Richard Brilliant, "Let the Trumpets Roar!' The Roman Triumph," in The Art of Ancient Spectacle, ed. B. Bergmann and C. Kondoleon (Washington DC, 1999), 221-229; Mary Beard, The Roman Triumph (Cambridge, Massachusetts, 2007), 143-86. Bernard O'Kane, "Domes," in Encyclopaedia Iranica vol. 7 (1995), 479-485; O. Reuther, "Sasanian Architecture, A History," in Survey of Persian Art, ed. A. Pope, (London, 1938), 501. On the related technique of pitched brick curved vault construction imported to the Roman Empire from the east at an earlier date, see Lancaster, "Parthian Influence.." 


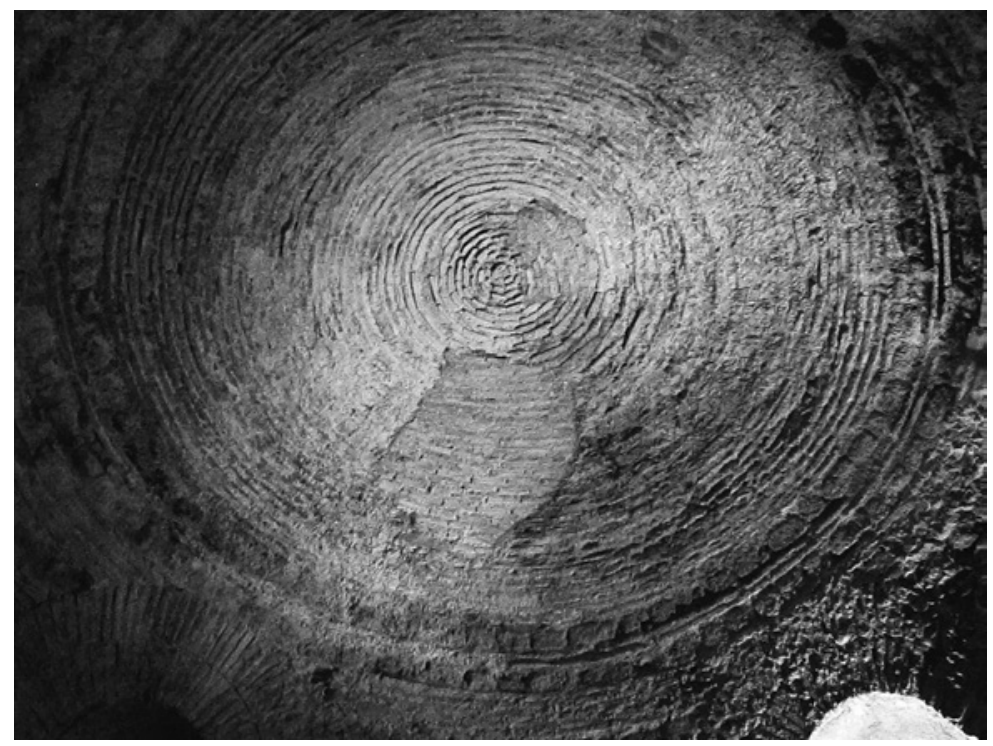

FIGURE 11.13 Pitched brick dome in a basement room of the residential apartments, Diocletian's palace, Split. The technique of executing domes with pitched courses of brick is unknown in imperial architecture before the Tetrarchic period and probably came to the Roman Empire from the east. AUTHOR'S PHOTOGRAPH.

for brick-making relative to stone and wood led to the development of this technique for dome construction. ${ }^{33}$ Pitched brick domes still stand today in Split's mausoleum, the domed throne room located directly behind the protyron, and in two rooms in the basement level of the palace's residential apartments (Figs. 11.11 and 11.13).

If, on analogy with Romuliana, it is assumed that soldiers were responsible for the construction of the palace at Split, it is not hard to imagine how such a constructional technique came to be introduced in the Roman Empire. Architects and engineers routinely traveled with the Roman troops, ${ }^{34}$ and as stated above, the very troops who built Romuliana were those who traveled in the preceding

33 Construction of domes from concrete or stone required the use of wooden centering. Brick domes, due to the relative levity of the material, required very little, if any, centering. See Ćurčić, Architecture in the Balkans, 40.

34 Appollodorus of Damascus, architect of Trajan's bridge over the Danube during the Dacian Wars of the early second century, is perhaps the most well known of the architects who travelled with the Roman army. On Appollodorus of Damascus, see P.H. Blyth, "Apollodorus of Damascus and the Poliorcetica," Greek, Roman, and Byzantine Studies 33 (1992), 127-158. 
years with emperor Galerius on his Persian mission. It is very much possible, therefore, that Galerius' imperial colleague (who had himself had experience in Persia) employed architects and engineers in the construction of the residence at Split who had firsthand experience of architecture in the rival realm.

Written sources and corroborating archaeological evidence also provide reason to think that forced deportations of war prisoners may have played a part in facilitating the exchange of ideas, technologies, and customs with enemy territories. In the course of the third-century conflicts between the Roman and Persian Empires, sources testify that both powers were responsible for the forced resettlement of thousands of their captured enemies within their own territories. ${ }^{35}$ Meanwhile, excavations and stylistic studies at the Sasanian site of Bishapur, a city built de novo by Shapur I as a sort of victory monument after his decisive mid-third century victory over the Romans at Edessa, point to the likelihood that captured Romans were among the workforce deployed in the construction of the city. ${ }^{36}$ Since it is certain that the Romans, like their Persian counterparts, subscribed to the practice of resettling foreign

35 Shapur I claims in his monumental inscription at Naqsh-i Rustam that he took prisoner a great number of Roman soldiers, generals, and high ranking elites after his victory at Edessa, and deported these individuals into the territory of Persis. In the same inscription, he also states that he deported Roman men from the cities he captured during his campaign and resettled them in the Persians' territories in Persis, Parthia, Khuzistan, and Babylonia. For an English translation of the inscription, see M. Sprengling, "Shahpuhr I, the Great on the Kaabah of Zoroaster (KZ)," American Journal of Semitic Languages and Literatures 57 (1940), 341-429, especially lines 11-16. For their part, the Romans enforced similar resettlements for the inhabitants of cities that they captured in the third and early fourth centuries. The panegyric delivered at Trier in honor of Constantius I in 297 CE records that Diocletian deported colonies of prisoners from Asia into Thrace. See Panegyrici Latini virı.21.1. Slightly later, Libanius mentions in an encomium for the emperor Constantius II (r. 337-61 CE) that the Romans captured a number of Sasanian cities in the course of war with the Persians and removed their populations to Thrace. See Libanius, Oration 59.83-4. For discussion of deportations as a source for transfer of artistic ideas between east and west, see Canepa, Two Eyes of the Earth, 27-29.

36 For the orthogonal plan of Bishapur and its connection with Roman military camp design, see Dignas and Winter, Rome and Persia (see above, n. 1), 254-7. For analysis of the decorative plasters, mosaics, and use of ashlar masonry at Bishapur and their connection to Roman craftsmen, see Canepa, Two Eyes of the Earth, 75-78; Edward J. Keall, "Bisapur" Encyclopaedia Iranica, 16 vols. (1989) Iv: 287-289; Roman Ghirshman, Iran from the Earliest Times to the Islamic Conquest (Harmondsworth, 1978), 140-9; Hubert von Gall, "Die Mosaiken von Bishapur," Archäologische Mitteilungen aus Iran IV (1971), 193-206; Roman Ghirshman, Fouilles de Châpour. Bîchâpour, 2 vols. (Paris, 1971) 2:38-148; Shepherd, "Sasanian Art," 1064-5 and 1075; Georges Salles, "Nouveaux documents sur les fouilles de Chapour, IV ${ }^{\text {me }}$ et Vme campagnes," Revue des arts asiatique XIII (1939-42) 98. 
populations within their own territory after conclusive military interventions (such as those leading up to the Treaty of Nisibis), it is conceivable that just like the contemporary practice in Persia, the Roman administration may have selected skilled individuals from among their captured and displaced enemies to work on imperial projects in Roman territories. Such practice would have held both practical and ideological weight and would certainly account for the introduction of a Mesopotamian building technique at Diocletian's palace.

Taken all together then, comparison between the late Roman palace at Split and Sasanian royal residences reveals a confluence of conceptual similarities and other physical evidence that suggest that contact and competition with the Persian empire in the latter part of the third century may account for the novelties observable in the non-urban Tetrarchic palatial architecture described above. The idea to experiment with the concept of a walled palace may have been spurred by contact with the Persians, even though aesthetically the concept is executed at these late Roman palaces in Greco-Roman formal vocabulary. Bolstering this argument is the similarity in both form and function of a specific, axially aligned and compact system of rooms in both the eastern and western palaces; further, in both cases, among this system of rooms was a prominently placed square throne room with domed roof executed in the Mesopotamian-derived pitched-brick building technique. That the construction technique and the use of such a room shape at this scale is unparalleled in Roman palace design, along with the prominence of these two features in Sasanian palaces dating slightly prior to the Tetrarchic examples strengthens the argument for palatial cross-fertilization at the end of the third century.

\section{Co-Opted Iconography: The Equestrian Duel}

Architecture was not, however, the only medium to see borrowings from the Persian east under the rule of the Tetrarchy. It was under Tetrarchic reign that a characteristically Persian iconography, that of two mounted main combatants engaged with one another in military confrontation, made its first appearance on a Roman imperial monument. ${ }^{37}$ Prior to this time, a number of imperial monuments envisioned the mounted Roman emperor taking a leading role in combat against the enemies of Rome regardless of whether he was actually known to have participated in the melee portrayed (Fig. 11.14). In the long history of such motifs in the Roman Empire, however, no Roman monument ever featured the mounted emperor in battle with an enemy on horseback-none, that is, until the Arch of Galerius in Thessaloniki (Fig. 11.15). 


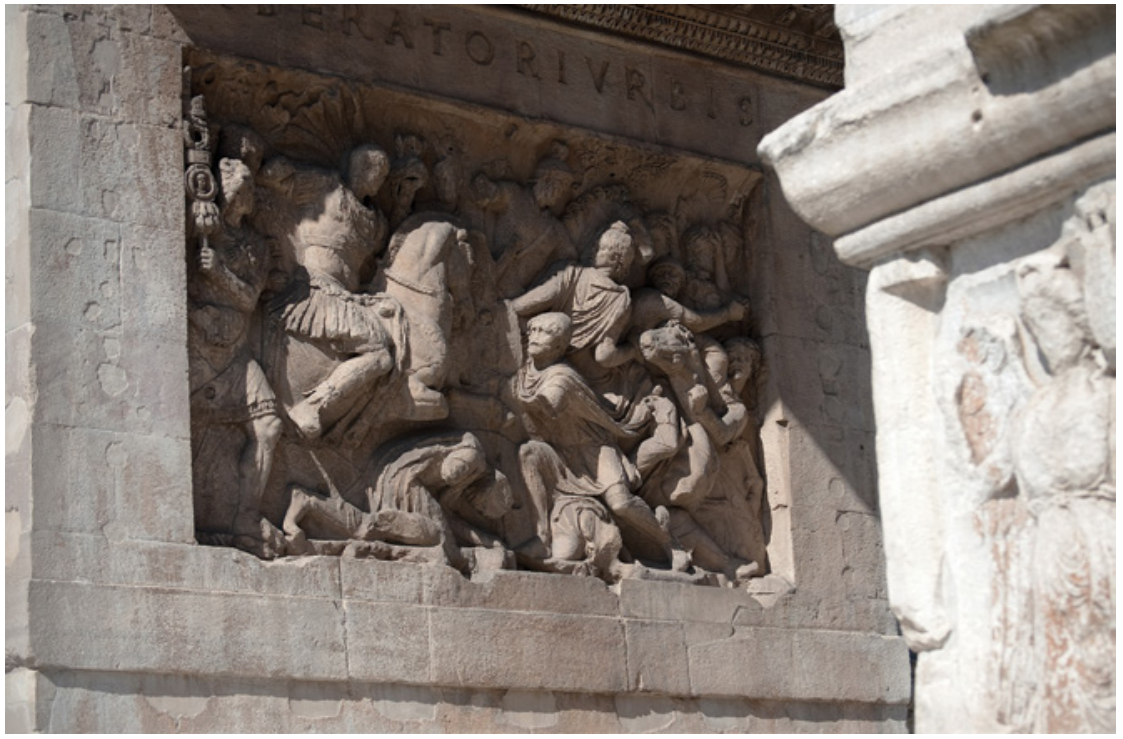

FIGURE 11.14 Great Trajanic Frieze, 2nd c. AD, reused on the Arch of Constantine, Rome.

(C) THE TRUSTEES OF COLUMBIA UNIVERSITY, MEDIA CENTER FOR ART HISTORY, DEPARTMENT OF ART HISTORY AND ARCHAEOLOGY.

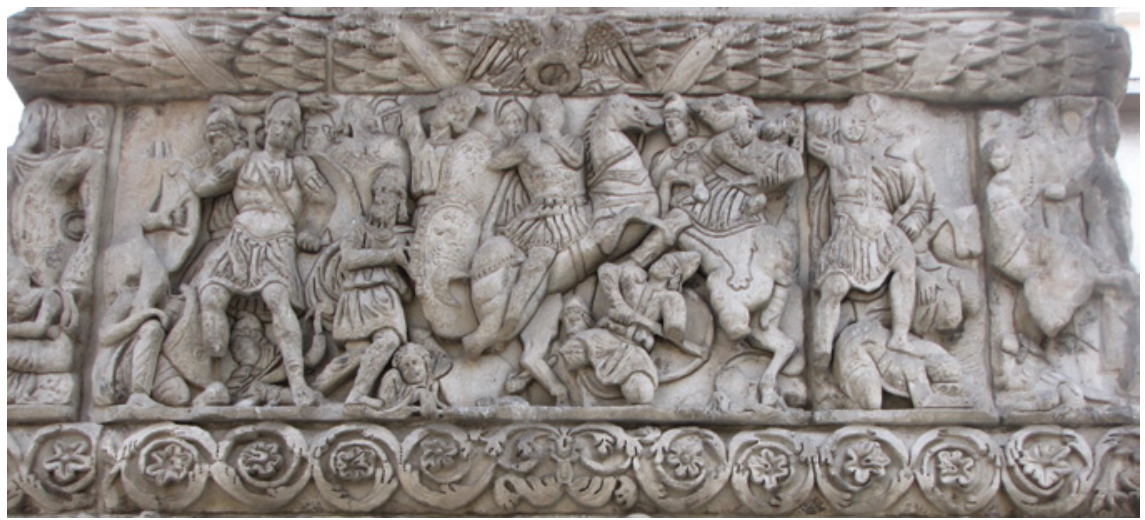

FIGURE 11.15 Equestrian duel relief. Arch of Galerius, Thessaloniki. AUTHOR's PHOTOGRAPH.

Placed conspicuously at the exact center of the relief composition, Galerius sits astride a charging horse. Both horse and emperor are outfitted with fine trappings befitting Galerius' status as Roman ruler. And while the figure of the Roman emperor is undoubtedly marked out as the focus of the scene, he confronts another figure, placed just to the right of the frieze's central axis, who is comparably mounted on the same groundline as the emperor and depicted 
as his equal in stature. On account of this egalitarian portrayal, the opponent, dressed in trousers and using a pantherskin as a horse blanket, is identified as Narses, king of the Sasanians. In his campaigns against the Sasanians Galerius never actually engaged in battle with the Sasanian king, and thus this vignette serves to visually panegyrize the emperor's virtus just like the reliefs of old, but this time using the new format of the equestrian duel.

What is important for our purposes is that although the imagery of an equestrian duel between ruler and opponent was new to the Roman repertoire, and lacked Hellenistic parallels as well, it had a history in Persian iconography both on monumental reliefs (Fig. 11.16) and on small, transportable objects (Fig. 11.17). ${ }^{38}$ Even more importantly, the composition had a history of being used to the detriment of Roman imperial reputation. The years leading up to the foundation of the Tetrarchy had seen a series of catastrophic military clashes against the Sasanians that resulted in repeated sackings for the Romans, as well as what was possibly the single greatest disaster the imperial Romans had ever suffered at the hands of an enemy - the first and only enemy capture of a Roman emperor. Capitalizing on his successes against the

38 The iconography of an equestrian duel between king and challenger seems to have been uniquely Iranian, with no Hellenistic precedent, and certainly no precedent in statesponsored Roman monumental art. The closest western parallel is the famous mosaic floor depicting Alexander's triumph over Persian opponents from the House of the Faun in Pompeii, dated to the second century вс but commonly presumed to be a copy after a Hellenistic painting. However, two important differences separate the mosaic's iconography from the Iranian equestrian duel imagery considered here, and thus the iconography preserved in the mosaic should not be seen as a Hellenistic precedent for the Parthian and Sasanian compositions. Whereas in the Iranian compositions king and challenger confront one another head-on, Darius III is portrayed running away from the battle by chariot. The Hellenistic composition thus robs the Persian king of any heroism, in stark contrast to the valorizing effect of the Iranian imagery. Also important is the fact that Alexander, though depicted as an active participant in the battle, is not militarily engaged with king Darius, but rather with one of the Persian foot soldiers. Although the post-Seleucid Persian dynasties and Romans alike were impacted by their exposure to Hellenistic iconographies, in this case the composition of two enemy rulers confronting one another in an equestrian duel is without comparable Hellenistic precedents. Therefore, the similarity between the equestrian relief from the Arch of Galerius and Sasanian equestrian imagery may not be explained as a case of Romans and Sasanians evolving similar iconographies from a common Hellenistic prototype. On the history of the equestrian duel iconography in Parthian and Sasanian art, see Canepa, Two Eyes of the Earth, 68-71; Hubertus Von Gall, Das Reiterkampfbild: in der iranischen und iranisch beeinflussten Kunst parthischer und sasanidischer Zeit (Berlin, 1990). On the Alexander Mosaic from the House of the Faun, see recently Ada Cohen, Art in the Age of Alexander the Great: Paradigms of Manhood and their Cultural Traditions (Cambridge, 2010), 162-70. 
Romans, the Sasanian king took the opportunity in the later part of the third century to assert his own status by propagating an unflatteringly impotent visualization of Roman power. ${ }^{39}$ It is in this respect that the equestrian duel imagery was put to use against the Romans. A cameo today in Paris portrays the capture of the emperor Valerian as a mounted battle between the Roman ruler and the Sasanian king (Fig. 11.17).$^{40}$

Although situated on an undeniably Roman style monument and embedded amongst traditionally Roman visual tropes - such as the compositional device familiar from imperial monuments and sarcophagi of staging bodies on high, middle and low visual planes to suggest the chaos of war; or the triumphant soldier treading upon a fallen enemy in a favored pose of Roman dominance-apparently the equestrian duel relief from the Arch of Galerius was intended to respond to its Persian model. ${ }^{41}$ The Tetrarchs' own Persian campaigns were predicated on the reassertion of Roman power in the East and

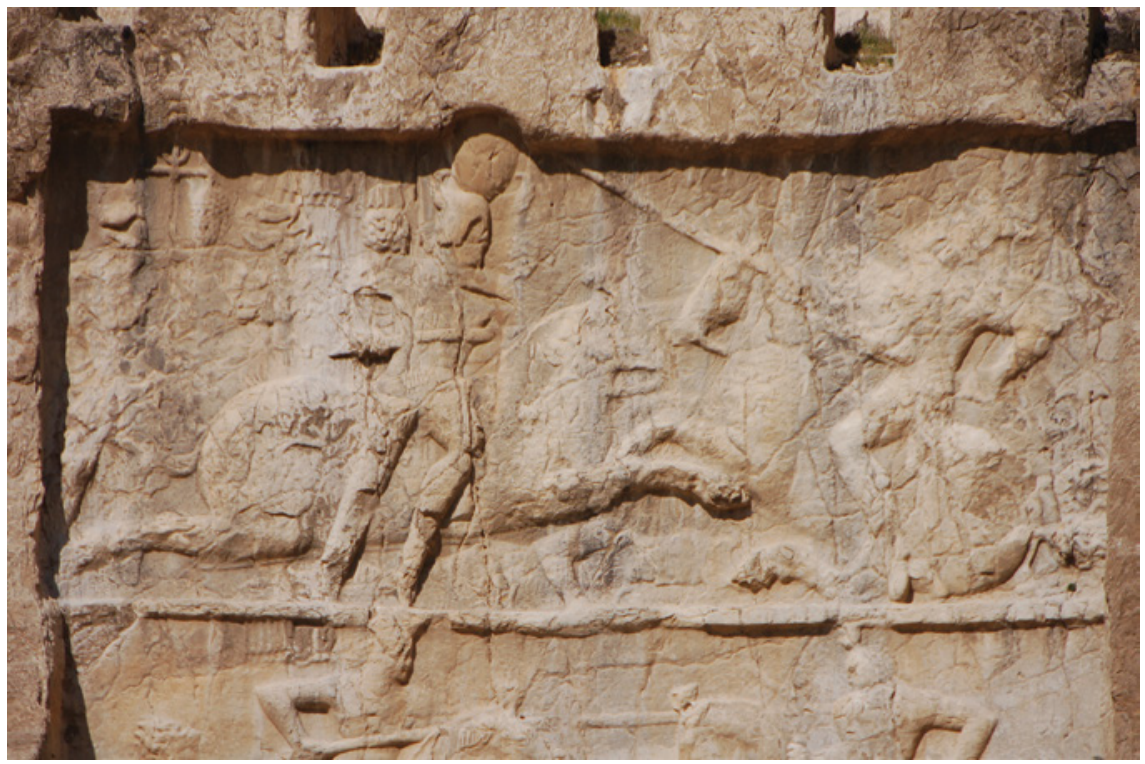

FIGURE 11.16 Equestrian duel between Sasanian King Bahram II and a challenger, bas relief from Naqsh-i Rustam. Third century AD.

PHOTOGRAPH COURTESY OF HELEN EVANS.

39 On Sasanian efforts to propagate an unflattering image of Roman power in the third century and Roman response to the provocation, see Canepa, Two Eyes of the Earth, pp. 53-99.

40 For recent discussion of the cameo and its connection to the equestrian duel imagery used on the Arch of Galerius, see ibid., 68-71, 93-94. 


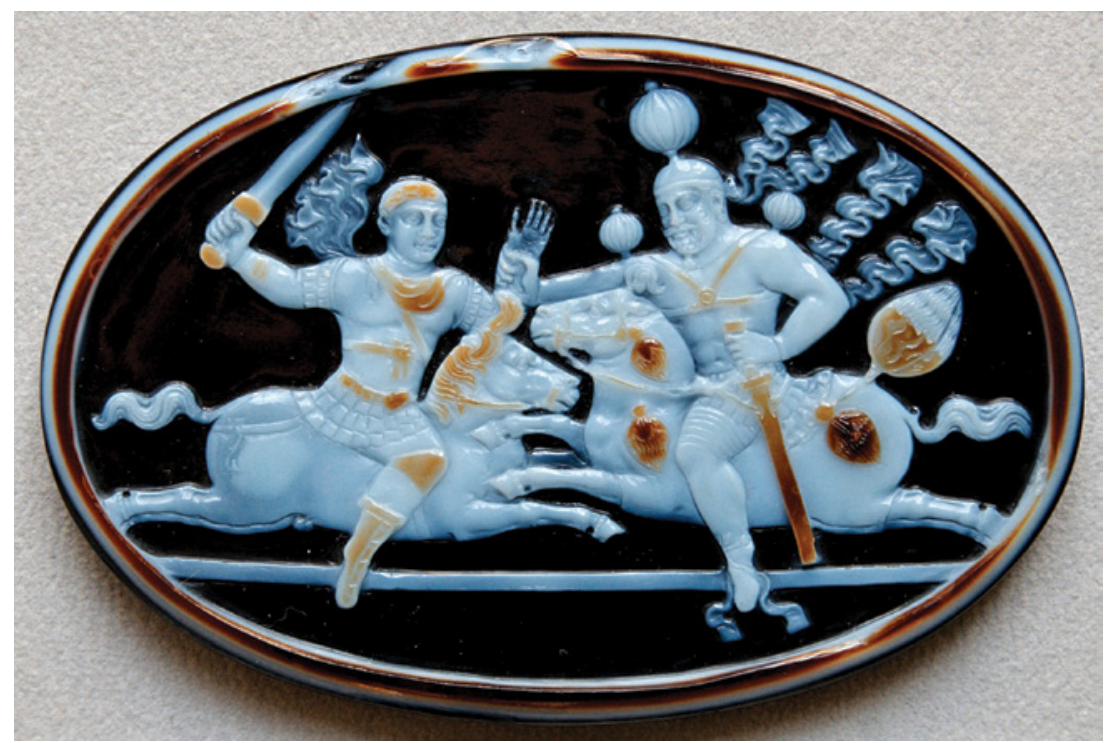

FIGURE 11.17 Sardonyx cameo featuring the Sasanian King of Kings capturing Emperor Valerian. Bibliotheque Nationale de France, Cabinet des médailles, inv. Babelon 360 . PHOTOGRAPH COURTESY OF MARIE-LAN NGUYEN, VIA WIKIMEDIA COMMONS/CC-BY.

the need to right the wrongs of the preceding years. ${ }^{42}$ It was a poignant choice to make use of this iconography at the historical moment when the balance of

42 There is good evidence that the mid-century Sasanian victories were still palpable, raw, and a motivating factor in Roman foreign policy even at the end of the third century. On the motivation for emperor Carus' campaign against the Persians, in which Diocletian and probably Maximan took part, see Anonymus post Dionem, Fragmenta Historicorum Graecorum 4, 198, frag. 12. In the end, the unexpected death of Carus at the height of the campaign caused the Romans to abandon what had been a very successful foray into Persian territory, therefore leaving the mission of absolute Persian disgrace frustratingly incomplete. The preamble to the Edict on Maximal Prices issued by the Tetrarchy in $301 \mathrm{AD}$ and Peter the Patrician's sixth-century account of Galerius' peace negotiations with a Persian ambassador in $298 \mathrm{AD}$ (written with access to imperial archives) both point to the Tetrarchic continuation of a deep-seated imperial drive to avenge the wrongs the Sasanians had perpetrated against the Romans. For a translation of the preamble and the list of prices, see Naphtali Lewis and Meyer Reinhold, eds. Roman Civilization. Selected Readings Edited with an Introduction, vol. 2 (1955), 464-72. For Peter the Patrician's account of the motivating factors for war between the Tetrarchs and the Sasanians, see Geoffrey Greatrex and Samuel N.C. Lieu, eds. The Roman Eastern Frontier and the Persian Wars. Part II, AD 363-63o: A Narrative History (London, 2002), 132. 
power had tipped back in Roman favor. In adopting and repackaging a Sasanian iconography in the context of a thoroughly Roman depiction of battle, the Romans turned on its head the same iconography that not long before was used to imply Rome's subjugation to the Sasanian king.

Embedding this borrowed iconography on the Thessaloniki arch not only conveyed Galerius' defeat of Narses, but also his success in defeating the Sasanian king at his own game, in his own visual vocabulary of military dominance. The Roman emperors and Sasanian kings of the third and early fourth centuries were locked in an international contest that pitted each ruler's conflicting claims to world supremacy against those of his challenger. In a clash such as this, rulers needed to make their assertions of power, strength, and ultimate supremacy legible not only to their own subjects, but also to the ruler and subjects of the enemy territory. ${ }^{43}$ Using this typically Sasanian iconography emphasized that, at long last, Galerius had literally reversed the fortunes of the Romans in their struggle against their eastern neighbors, and it did so in a visual idiom that was legible to both Romans and foreigners alike.

\section{Diocletian's Palace in a New Light}

Tetrarchic fortified palaces, including Diocletian's palace in Split, can almost certainly be understood in this same light. Both the borrowed iconography and the architectural similarities appeared in Roman dominions at the same time - that is after decisive Roman defeat of their Sasanian enemies in the late 29os AD. Like the co-opted iconography, architectural reference to Sasanian models served the dual purpose of 'cultural booty' on the one hand, and on the other, functioned to extend the legibility of the Roman emperor's propaganda to a wider, more international audience. ${ }^{44}$ In support of this latter point, it is striking that these adopted ideas were not put to use haphazardly, but rather strategically used in palaces, that is, contexts that international observers, be they kings, emissaries, high-ranking hostages or ambassadors, could be expected to encounter. ${ }^{45}$

\footnotetext{
43 Canepa, Two Eyes of the Earth, 1-5.

44 Ibid., 1-5, 21-22.

45 For a general discussion on the topic of Romano-Persian diplomacy and the exchange of ambassadors, see Dignas and Winter, Rome and Persia, 245-54. On its more specific implications for the exchange of ideas between the Roman and Sasanian empires and the viewership of the Arch of Galerius, see Canepa, Two Eyes of the Earth, pp. 30-31, 96. Ammianus Marcellinus writes that in the case of the treaty between Shapur II and Jovian,
} 
In fact, written sources of the period suggest that Persian presence at the Roman court in the third and fourth centuries was by no means unusual, thus the ideological impact of the elements the Romans borrowed from the east would have been readily legible to an important part of the population who encountered them. The relief representation of the eastern palace at Ctesiphon from Severus' arch in Rome, and the triumphal paintings on which it may have been based, ${ }^{46}$ on the other hand, remind us that Persians were likely not the only ones capable of reading the significance of Split's foreign architectural referencing. The Severan relief's summary architectural rending suggests that for the diverse audience in the city of Rome it was a fortification wall marking off a group of component buildings and a prominently placed, square footprinted building with a domed roof that were the most readily identifiable elements of a Persian palace. Thus the placement of Diocletian's palace inside its own walled enclosure and the use of the distinctively shaped and organized audience suite at Split may indeed have been legible to individuals from a variety of backgrounds within Roman territory.

With a legacy of embarrassing defeats at the hands of the Sasanians in the third century, the Tetrarchs needed to both redress the image of Roman power propagated by the Sasanians and self-fashion a counter-image that adequately competed with that of the eastern rival who had so recently held the upper hand. The Roman emperors' selective import, adaptation, and repackaging of aspects gleaned from the court of their Sasanian neighbors served exactly this purpose ${ }^{47}$ In forwarding this thesis, it is important to note this was not the first time that after a significant victory the Romans co-opted and redeployed architectural features originating in a culture they deemed a

the Romans and Sasanians both sent groups of high ranking elites to the court of the other to act as hostages; these individuals were intended to serve as collateral ensuring that both sides would keep to the terms of the peace contract. See Ammianus Marcellinus 25.7.9-14. Although there is no comparable source definitively stating that the Romans and Sasanians arranged for a similar exchange of elites in the Tetrarchic period, the idea is at least conceivable given that the two powers completed the major diplomatic Treaty of Nisibis in 298/9 AD. Whether or not long-term hostages were held at the Roman court following the peace with Narses, it is undeniably the case that the Romans held the Persian harem and a group of Persian nobles for a period of time following the Romans' decisive 298 AD victory at Satala. For the capture of the harem, see Eutropius, Breviarium, 9.25; Festus, Breviarium. 25; Petrus Patricus, frag. 13-14.

$46 \quad$ See above n. 31.

47 Canepa, Two Eyes of the Earth, 21-22, 53-99. 
decadent 'Other' —one need only look to Augustan Rome following the Battle of Actium for parallels. ${ }^{48}$

Roman emperors could borrow from the enemy when it suited their purposes, but this had to be done with care. In every case, the features the Romans chose to adopt from Persia were those that had relevance within their new Roman setting and blended easily with elements of an established Roman pedigree so as not to openly announce their foreign extraction. At Split, the idea to establish a fortified palace may have been transferred from the east, but the walls and military-inspired features that enclosed the complex were Roman in style. Likewise, for all its conceptual, organizational similarity with Sasanian palaces, all of the constituting features in Diocletian's palace were translated into decisively Roman architectural terms - perhaps most conspicuously, a peristyle courtyard took the place of the typically Sasanian aiwan. Such design allowed those critics who might otherwise have taken objection to imperial adoption of foreign elements or practices within the Roman realm to conveniently overlook them.

The blinkered view of the Late Antique world shaped by culturally-isolationist disciplinary trends is finally in retreat. The parallels illustrated here between Roman and Sasanian palatial architecture introduce not only a new way of viewing Diocletian's palace at Split, but also a new way of understanding Late Antique palace design as an ingredient in the negotiation of power relationships between Rome and her enemies. As part of an ever-advancing field, new discoveries and methodologies should always call us to reevaluate, revise, and expand the conclusions we draw from even those monuments deeply etched in the historical canon.

48 On the horologium of Augustus and the general use of obelisks in Augustan Rome as cultural booty signaling the Roman victory at Actium, see Molly Swetnam-Burland, "Aegyptus Redacta: Augustus' Obelisk in the Campus Martius" Art Bulletin 92, no. 3 (2010), $135^{-153}$. 


\title{
The Reception of Figurative Art Beyond the Frontier: Scandinavian Encounters with Roman Numismatics
}

\author{
Nancy L. Wicker
}

The distribution of images of the Roman emperor, from portrait busts to miniature numismatic art, was key to the creation of the sprawling 'imagined community' of the Empire. ${ }^{1}$ Such images were ubiquitous across the empire, through the provinces and beyond, with coins reaching as far away as Scandinavia. In this paper, I present a case-study of a small number of fourthcentury Late Roman medallions that were brought to the North and inspired a new type of object, the Scandinavian gold bracteate of the Migration Period in the fifth and sixth centuries. My goal is to examine how the imagery of the medallions was received and imitated in the North, that is, the impact of the empire on Scandinavian visual representation. In this encounter, the miniature figural art of Roman medallions was incorporated into a culture that had an appreciation for animal ornamentation, had its own writing system in the form of runes, and used reciprocity and other forms of exchange before an incipient monetary economy began during the Viking Age late in the ninth or tenth century. ${ }^{2}$

With the influx of Roman coinage, Scandinavia played a role in the extended Empire simply by virtue of obtaining and using medallions. Although metal pendants with figural images had not been not part of the repertoire of northern goldsmiths prior to the Later Roman Iron Age of the third and fourth centuries $\mathrm{AD}$, medallions with suspension loops reached a receptive audience there. However, northerners adapted the essence of these fourth-century Imperial pieces into something that became emblematic of their own culture as they

1 The general idea of 'imagined communities' is introduced by Benedict Anderson, Imagined Communities: Reflections on the Origin and Spread of Nationalism, rev. ed. (London, 2006); and the concept is applied to the Roman Empire by Carlos Noreña, Imperial Ideals in the Roman West: Representation, Circulation, Power (Cambridge, U.K. 2011), 304.

2 Brita Malmer, 'South Scandinavian Coinage in the Ninth Century', in James GrahamCampbell, ed., Silver Economy in the Viking Age, Publications of the Institute of Archaeology, University College London (Walnut Creek 2007), 13. 
altered the physical characteristics, figural images, inscriptions, and functions of these objects. The numismatic type was modified but still traceable in the one-sided Nordic gold bracteates of the following century and a half. In this paper, I will first review how medallions may have been used and brought to the North and then I will summarize what we know about the use of Migration Period bracteates. ${ }^{3}$ After setting the stage with this background information, I will examine the artistic transformation of the portrait image from medallion to bracteate.

Medallions are multiples of the solidus that were made for ceremonial occasions and distributed by emperors to military leaders, who in turn gave them to soldiers to reward military valor and strengthen political bonds. ${ }^{4}$ The only extant documentary information about how these numismatic issues were used is a sixth-century account in which Gregory of Tours describes medallions that the emperor Tiberius had given to the Frankish king Chilperic. ${ }^{5}$ Although many medallions were framed and provided with loops for suspension, Gregory did not indicate whether Chilperic's pieces were plain or embellished.

Illustrations of men wearing pendants similar to medallions, as displayed on the late fourth-century silver ceremonial dish known as the Missorium of Theodosius and on the mid-sixth-century mosaic of Justinian I and his attendants at San Vitale in Ravenna, show how the display of comparable adornments was represented in monumental form and in the decorative arts. ${ }^{6}$ From Gregory's account and such visual parallels we reconstruct how medallions were dispensed to and worn by Germanic leaders, thus extending the reach of the 'imagined' larger community of the Roman Empire. The medallions are evidence not only of direct contact between the empire and Scandinavia, but

3 I examine this material in more detail in Nancy L. Wicker, 'Inspiring the Barbarians? The Transformation from Roman Medallions to Scandinavian Bracteates', in Peter S. Wells, (ed.), Rome beyond Its Frontiers: Imports, Attitudes and Practices. Journal of Roman Archaeology Supplementary Series 94 (Portsmouth, R.I. 2013), 105-120.

4 Nils Ludvig Rasmusson, 'Were Medals of Merit Used and Worn in Antiquity?' Acta Archaeologica 16 (1945), 211-222; and Valerie Maxfield, The Military Decorations of the Roman Army (Berkeley 1981).

5 Gregory of Tours, Historia Francorum 6.2 2. Lewis Thorpe (ed. and trans.), The History of the Franks (Harmondsworth 1974), 328.

6 John Beckwith, Early Christian and Byzantine Art, 2nd ed. (Harmondsworth 1979), 77, 114. 
also of the exchange of information between individuals and communities, thus of what may be discussed as the 'entanglement' of Rome and the North. ${ }^{7}$

In addition to genuine Roman medallions struck to the solidus standard under imperial control, barbarian medallion imitations were also produced, probably in Eastern Europe along the Danube or in the Black Sea area, as ascertained by significant finds of such artifacts in these areas. ${ }^{8}$ The imitations mimic the appearance of their medallion models and were made by the same methods, yet they routinely were looped and thus intended to serve as ornamentation rather than coinage. The very production of imitations demonstrates that there was interest in these objects and a desire for more of them than was afforded by the supply of authentic multiples that reached Barbaricum. Both medallions and their imitations were distributed broadly, even to the far north (Fig. 12.1), ${ }^{9}$ leading us to conjecture whether the individuals who used them were familiar with Roman customs and the usage of such objects.

Seven fourth-century Roman medallions as well as thirteen imitations have been found in Denmark, Norway, and Sweden. ${ }^{10}$ The imitations were struck by the same numismatic methods as genuine coins, with figures (and often inscriptions) in low relief on both obverse and reverse; the emperor's head

For discussion of the concept of 'entanglement', see Ian Hodder, Entangled: An Archaeology of the Relationships between Humans and Things (Malden, Mass., 2012); and Michael Dietler, Archaeologies of Colonialism: Consumption, Entanglement, and Violence in Ancient Mediterranean France (Berkeley 2010).

Alexander Bursche, 'Roman Gold Medallions as Power Symbols of the Germanic Élite', in Bente Magnus (ed.), Roman Gold and the Development of the Early Germanic Kingdoms," Konferenser $5^{1}$ (Stockholm, 2001), 92; and Helle Horsnæs, Crossing Boundaries: An Analysis of Roman Coins in Danish Contexts. Vol. 1: Finds from Sealand, Funen and Jutland. Publications of the National Museum. Studies in Archaeology and History 18 (Copenhagen 2010), 187 .

9 Bracteates (and medallion imitations found in Scandinavia) are cited with catalogue numbers "IK" (= Ikonographische Katalog) for the 7-volume catalogue organized by Karl Hauck, et al., Die Goldbrakteaten der Völkerwanderungszeit (Munich 1985-1989).

All photographs in this chapter are licensed under Creative Commons, as follows:

"Bilder i Sök i samlingarna är, om inte annat anges, licensierade för icke-kommersiell användning som kopiering, distribution och visning med en http://www.creativecom mons.se/?page_id=92 Creative Commons-licens. På bildens sida länkas till gällande licens och där kan du se detaljer kring licensen och hur du får använda bilden. Du har rätt att kostnadsfritt använda bilden för icke-kommersiellt bruk enligt licensen om du anger fotograf/upphovsman, källa ("Historiska museet" eller "sнm")."

The exact numbers depend upon whether a strict or loose definition of 'medallion' is used. See Wicker, 'Inspiring the Barbarians?' 105. 


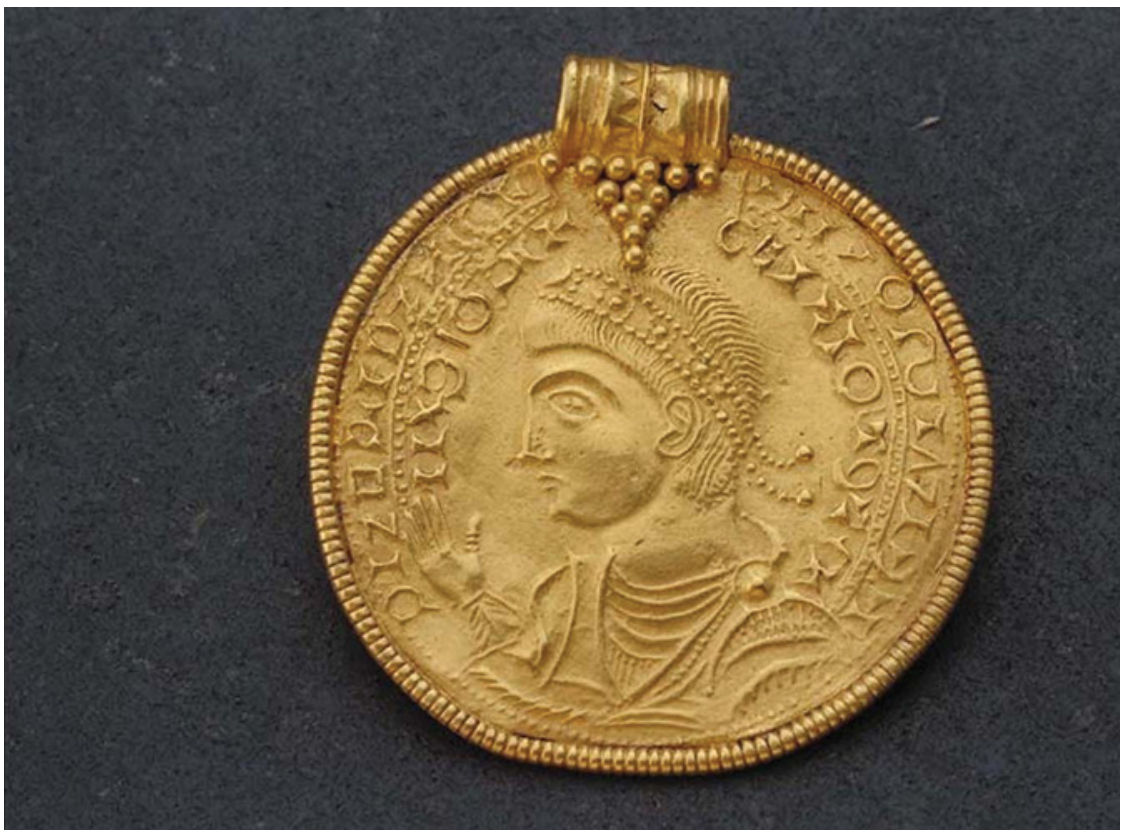

FIGURE 12.1 Medallion imitation (IK 107), from LillaJored, Bohuslän, Sweden; Statens Historiska Museet, Stockholm, inv. no. 421; diam. $3.9 \mathrm{~cm}$.

(PHOTOGRAPH NO. 14710 BY ULF BRUXE, SHM 1993-06-18)

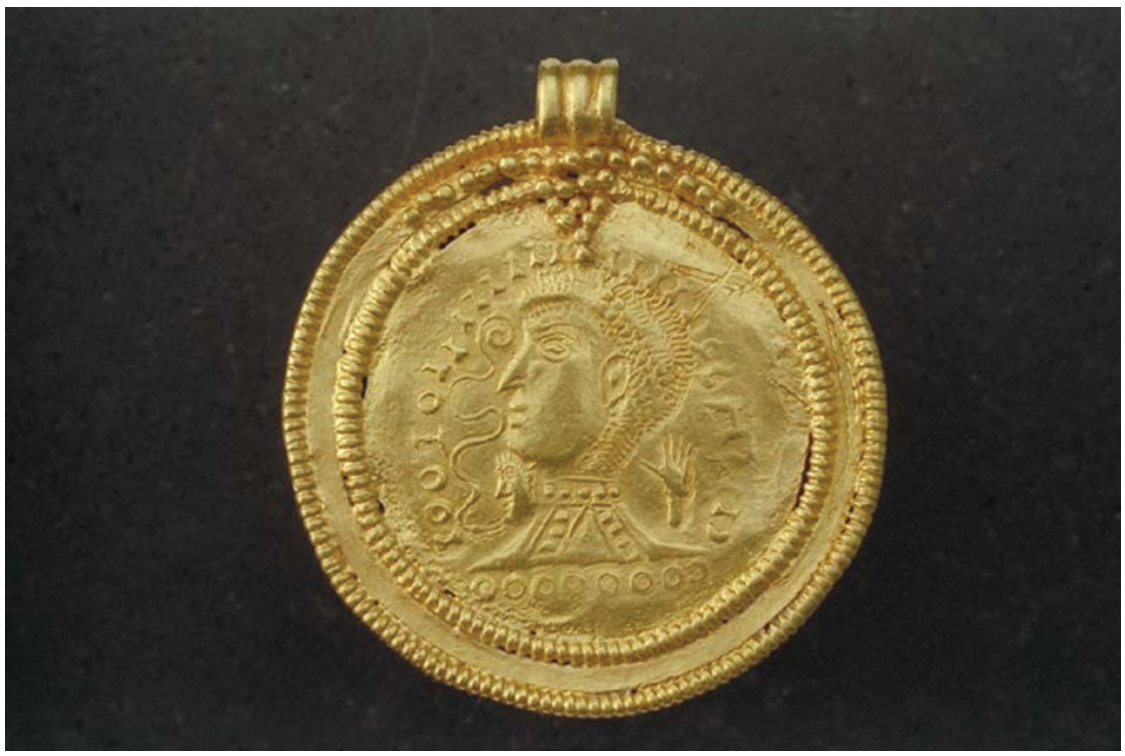

FIGU RE 12.2 Medallion imitation (IK 14), from Aneby, Småland, Sweden; Statens Historiska Museet, Stockholm, inv. no. 20510; diameter $3.76 \mathrm{~cm}$.

(PHOTOGRAPH NO. 13558 BY ULF BRUXE, SHM 1993-08-02) 
is depicted and the Roman letters are sometimes clear, yet both pictures and inscriptions are frequently corrupted (Fig. 12.2).

How the solidus multiples and their imitations reached the North is unknown; nonetheless, it is presumed that they were brought by men who had obtained them as diplomatic gifts or as rewards for meritorious military service in the auxiliaries. ${ }^{11}$ The promise of citizenship upon retirement is often cited as an enticement for barbarian enlistment in the military, although documentation of actual Scandinavian participation in the imperial forces is lacking. ${ }^{12}$ We know little about how medallions and imitations were used in the North, and the fact that all but one of these examples were discovered in the nineteenth century as stray finds or from sites not excavated to modern standards hinders the assignment of gender to what may have been cremation and inhumation burials. ${ }^{13}$ All of these pieces discovered in Scandinavia have (or preserve traces of) suspension loops with signs of wear, so we deduce that they were worn. Ultimately, the nature of the adaptation from the Roman model that is evident on the medallion imitations prefigures a more extended process of reinterpretation that continues with the Nordic artifacts known as bracteates.

\section{Bracteates}

As looped pendants with figurative images and sometimes with inscriptions, Scandinavian Migration Period gold bracteates superficially resemble Roman medallions (Fig. 12.3).

Although similar to medallion imitations in that they were made for display rather than coinage, bracteates differ significantly from medallions and their imitations in their one-sided technique and usage of runic characters instead of Roman capitals. ${ }^{14}$ The change in production method from numismatic two-sided striking to bracteate one-sided stamping is a matter of both

\footnotetext{
11 Alexander Bursche, 'Die römischer Goldmedaille in der Spätantike', in Wilfried Seipel, ed., Barbarenschmuck und Römergold: Der Schatz von Szilágysomlyó (Vienna 1999); and Bursche, 'Roman Gold Medallions'.

12 Maureen Carroll, Romans, Celts and Germans: The German Provinces of Rome (Stroud, 2001), p. 105; and Gad Rausing, 'Barbarian Mercenaries or Roman Citizens?' Fornvännen 82, nos. 2-3 (1987), 126.

13 Wicker, 'Inspiring the Barbarians?' 113-116; and Kent Andersson, Romartida guldsmide i Norden, III: Övriga smycken, teknisk analys och verstadsgrupper. Occasional Papers in Archaeology 13 (Uppsala 1995), 44-45.

14 Wicker, 'Inspiring the Barbarians?' 105-120.
} 


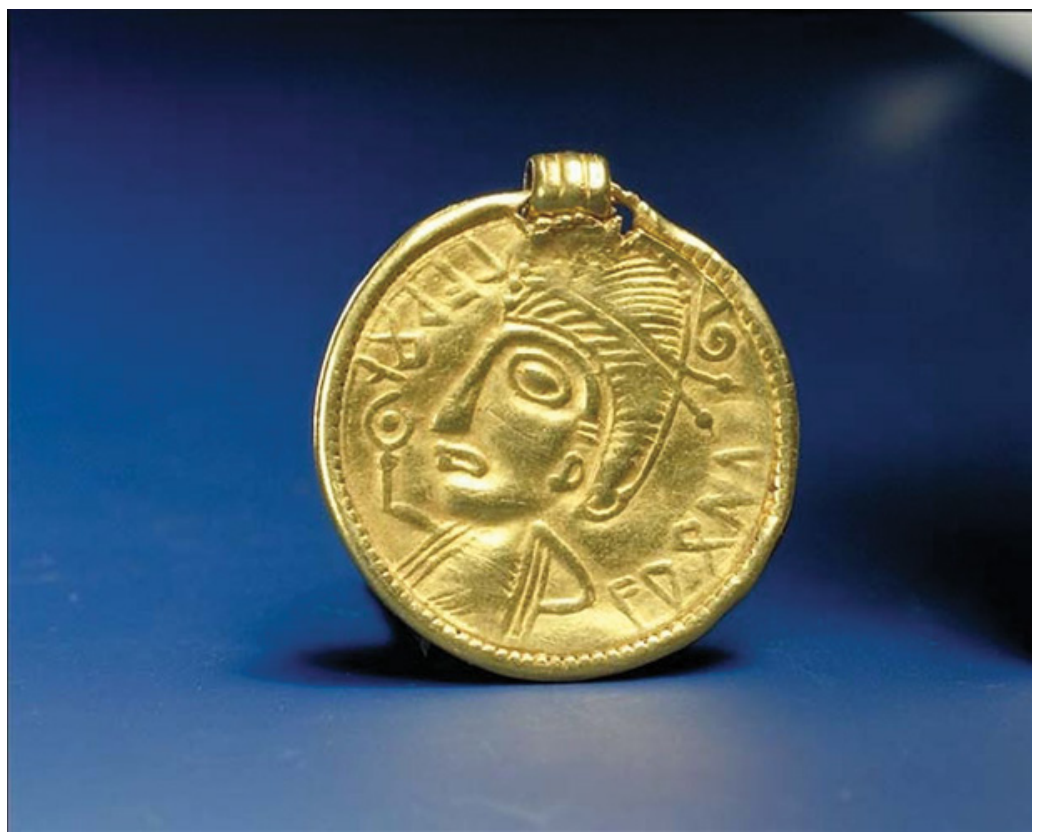

FIGURE 12.3 Type A bracteate with runic inscription (IK 189), from Trollhättan, Västergötland, Sweden; inscription: tawol apodu (indecipherable); Statens Historiska Museet, inv. no. 1164; diam. $2.33 \mathrm{~cm}$.

(PHOTOGRAPH NO. 17633 BY GUNNEL JANSSON, SHM 1995-07-31)

technology and economics - stamping is easier to execute and can be accomplished with very thin metal, thus requiring less gold than medallions struck from two sides simultaneously. While interest in continuing the foreign concept (although not the technique) was demonstrated, substituting Germanic runes for Roman letters demonstrates that the southern model was adapted to a local, northern audience.

Inscriptions on some bracteates include Proto-Scandinavian words lapu (invitation), laukaR (leek), and alu (ale) that Anders Andrén proposes reflect the general significance of Latin dominus, pius, and felix on coins and medallions. ${ }^{15}$ Though his rather convoluted argument has not been accepted by philologists, ${ }^{16}$ Andrén's suggestion that the words were of equivalent impor-

15 Anders Andrén, 'Guld och makt—en tolkning av de skandinaviska guldbrakteaternas funktion', in Charlotte Fabech and Jytte Ringtved (eds.), Samfundorganisation og regional variation: Norden i romersk jernalder og folkevandringstid. Jysk Arkæologisk Selskabs Skrifter 27 (Højbjerg 1991), 248-252.

16 Henrik Williams, in Nancy L. Wicker and Henrik Williams, 'Bracteates and Runes', Futhark: International Journal of Runic Studies 3 (2012, publ. 2013), 194. 
tance rather than the same literal meaning may be on the right track to explain how bracteates rendered ideas pertinent to Germanic society. In addition, the degree of similarity between figural images on medallions and on bracteates reveals that there was still a continuing connection to and entanglement with the Roman background. Was this link due to a long-term memory of foreign ties held by certain members of Nordic society? If medallions found in the North were brought there by soldiers who had served as mercenaries, how long after the return of these men to their home did knowledge of representations of the emperor survive? Did the tradition of medallions as gifts in reward for loyalty persist with bracteates in Scandinavia? An examination of who used these objects and how they exploited them may shed light on whether the Roman tradition was indeed carried on.

\section{Use of Medallions, Imitations, and Bracteates in Scandinavia}

Our limited testimony for the usage of medallions from Gregory of Tours and various visual sources leads us to believe that men on the Continent were awarded these objects and wore them suspended around their necks as marks of military distinction. Without such documentary and visual evidence in Scandinavia, we look for contexts that help us understand how they were treated. As noted earlier, we lack sufficient reliable information about find circumstances of medallions and have only little more evidence for the imitations. A triple solidus of Valentinian (r. 367-375) from Vestre Hauge in Norway may be from a female burial, as ascertained by the presence of beads typically worn by women, whereas three imitation medallions are believed to come from male and two from female burials, also on the basis of characteristic gendered grave goods. ${ }^{17}$ Notwithstanding the small numbers of examples, the contextual archaeological evidence challenges the male interpretation of the admittedly inadequate visual and documentary material by demonstrating a female connection to these objects. A possible shift in gendering the function of pendants from male to female may signal a conscious or unconscious rejection of the Roman tradition of how to display medallions-a shift in usage that was carried further with bracteates.

With over one thousand bracteates extant, ${ }^{18}$ we have sufficient information about find contexts to tempt us to assess the gendered use of some them, even

17 Andersson, Romartida guldsmide i Norden, 43-45; and Åsa Dahlin Hauken, The Westland Cauldrons in Norway. AmS-Skrifter 19 (Stavanger 2005), 78.

18 In December 2010, 1003 bracteates were known, according to Morten Axboe, 'Die Chronologie der Inschriften-Brakteaten', in Wilhelm Heizmann and Morten Axboe (eds.), Die 
though stray finds during agricultural work and undocumented finds account for a large number of them, approximately thirty percent. ${ }^{19}$ Roughly fifteen percent were discovered in burials and fifty-five percent in hoards-caches of materials buried in the ground perhaps for safekeeping or as offerings. ${ }^{20}$ The geographic distribution of find types is not uniform. In southern Scandinavia, the core area of bracteate discovery, hoards are ubiquitous, whereas burials dominate in the more peripheral areas of the distribution, including western Norway, the island of Gotland, England, and Continental Europe except for the northernmost areas of Germany and Poland — where, as in neighboring southern Scandinavia, they are found in hoards. ${ }^{21}$ Almost all of the graves in which bracteates were deposited are judged to be female burials according to grave goods and skeletal analysis, allowing that there are considerable difficulties with such assignments. ${ }^{22}$ The bracteates are looped and lay on the chest area as pendants, usually in association with other jewelry. The few examples from male burials have no loops and thus were not suspended as pendants; instead their find circumstances reveal that they were used in other ways - two were Charon's obols discovered in the mouth cavity and one was lying along the side of the body as if in a cloth or leather bag. ${ }^{23}$ Interestingly, the composition of many bracteate hoards reflects the sets of women's jewelry normally found in burials, ${ }^{24}$ thus raising the question of whether the hoards as well as the typical burials were gendered female and reiterating the need to examine how bracteates were associated with women.

While medallions and medallion imitations may have been presented by men to other men, following the Roman custom, we have little information about their subsequent use. In regard to military decorations, Valerie

Goldbrakteaten der Völkerwanderungszeit-Auswertung und Neufunde. Ergänzungsbände zum Reallexikon der Germanischen Altertumskunde 40 (Berlin 2011), 296.

19 I cite percentages of various find contexts from my personal database of bracteate finds.

20 Richard Bradley, The Passage of Arms: An Archaeological Analysis of Prehistoric Hoards and Votive Deposits (Cambridge 1990).

21 For a distribution map marking the find contexts, see Andrén, 'Guld och makt', 248.

22 See for instance Bettina Arnold, 'Gender and Archaeological Mortuary Analysis', in Sarah Milledge Nelson, ed., Handbook of Gender in Archaeology (Lanham, Md. 2006), 137-170.

23 See Morten Axboe, 'Der Brakteat aus Roirhage und seine Verwandeten. Zum Problem der Charonspfenninge in Skandinavien', in Jan Peder Lamm and Morten Axboe, 'Neues zu Brakteaten und Anhängern in Schweden', Frühmittelalterliche Studien 23 (1989), 465-473; and D.R.J. Perkins and Sonia Chadwick Hawkes, 'The Thanet Gas Pipeline Phases I and II (Monkton Parish), 1982', Archaeologia Cantiana 101 (1984), 105.

24 John Hines, 'Ritual Hoarding in Migration-Period Scandinavia: A Review of Recent Interpretations', Proceedings of the Prehistoric Society 55 (1989), 193-205. 
Maxfield suggests that 'When not being worn...the dona would presumably be deposited somewhere safe..... Alternatively, they might be put on display' ${ }^{25}$ Scandinavians apparently resisted following the foreign model of how such objects were given and exhibited, perhaps breaking the mold already with medallions - which are found occasionally with women-but certainly with bracteates, which we find displayed on women's bodies. How did women initially obtain bracteates? Birgit Arrhenius suggests that these objects were given by men to women, perhaps as bride-price. ${ }^{26}$ Once in the hands of women, they may have been inherited by their daughters as Sonia Hawkes proposes, and thus they passed through the female line. ${ }^{27}$ Yet, just as medallions indicated high status for soldiers who received them as gifts, bracteates would remain a marker of the elite-now expressed as a new behavior centered on women rather than men. Henceforth, women carried forward the tradition of wearing pendants with figural imagery based on the Roman emperor's portrait, and the figural image on bracteates was subsequently redistributed over much of Europe in the later fifth and sixth centuries as jewelry worn by females. In these new environments, the revised symbol of empire encountered other traditions (Anglo-Saxon, Byzantine, Merovingian, etc.) that continued the thread from Roman art in a different manner.

\section{$4 \quad$ Figural Imagery}

Although schematic stick-figure humans were common in rock carvings of the Late Bronze Age (ca. 1100-500 BC) in Scandinavia, figural art was rare and alien in this region throughout the Iron Age-from the Pre-Roman Iron Age (ca. 500 BC-AD 50) continuing through the Viking Age (ca. AD 800-1050). A few three-dimensional wooden sculptures are known, including a priapic figure from Broddenbjerg bog in central Jutland, C-14 dated to $535-520$ в ${ }^{28}$ and a seated effigy from Rude Eskilstrup on Zealand, dated to the 5 th century AD

25 Maxfield, Military Decorations, 143.

26 Birgit Arrhenius, 'Smycken som diplomati', in Katarina Ågren (ed.), Föremål som vittnesbörde: En festskrift till Gertud Grenander Nyberg på 8o-årsdagen den 26 juli 1992 (Stockholm 1992), 18-25.

27 Sonia Chadwick Hawkes and Mark Pollard, 'The Gold Bracteates from Sixthcentury Anglo-Saxon Graves in Kent, in the Light of a New Find from Finglesham, Frühmittelalterliche Studien 15 (1981), 339.

28 Klaus Ebbesen, 'Broddenbjerg-manden: en gudestatue og andre gudestatuer fra bronzealderen', Fra Viborg-egnen, 76 (2011), 37-48. 
based on the neck-ring depicted on the man. ${ }^{29}$ However, two-dimensional graphic figures were particularly avoided in the North. I would like to consider this scarcity in the context of Ernst Gombrich's examination of the seemingly obvious observation that the expression of 'mimesis' (imitation of the natural world) is more direct in the actual three-dimensionality of sculpture than in the creation of the illusion in painting and drawing. ${ }^{30}$ Thus in many cultures, including Iron Age Scandinavia, figures on a flat or nearly flat surface (allowing for low relief) are abstracted even though sculptural works in the same tradition may be relatively representational.

When the human figure is visible in Iron Age Scandinavia, often only the head or face is included. For instance, so-called 'Celtic' masks executed in sculptural relief are displayed on the Gundestrup cauldron, which was found in Denmark although presumably imported from elsewhere, perhaps southeastern Europe. ${ }^{31}$ 'Celtic' full-face masks show what Gombrich calls the 'distinctive features' of a human face - two eyes, a nose, and a mouth - the attributes that are focused on in artwork by children and the unschooled as well as the 'primitive. ${ }^{32}$ On the other hand, the profile bust in bas relief, introduced into Scandinavia on Roman coinage from the Republican Period onwards, ${ }^{33}$ relies on what Gombrich explains as 'seeing' rather than 'knowing.. ${ }^{34}$ The frontal image, used occasionally on bracteates (Fig. 12.4), depends upon the artist's knowledge of what constitutes a face rather than actual perception of what is seen, whereas the side view is dependent upon or connected to direct observation of the subject.

29 Birgit Arrhenius, 'Järnåldern', in Stenåldern, Bronsåldern, Järnåldern, Signums svenska konsthistoria 1 (Lund, 1994), 189-190; and Hans Jørgen Frederiksen and Inger-Lise Kolstrup, Ny Dansk Kunsthistorie, vol. 1. Troens kunst (Copenhagen 1993), 23.

30 Ernst H. Gombrich, The Preference for the Primitive: Episodes in the History of Western Taste and Art (New York 2002), 271-273.

31 The origin of the Gundestrup cauldron is disputed. Helmut Birkhan notes its connections to Thracian metalwork and proposes its manufacture around 100 BC. Kelten: Bilder ihrer Kultur/Celts: Images of Their Culture (Vienna 1999), 17, 25.

32 Gombrich, The Preference for the Primitive, 274.

33 Helle W. Horsnæs, Crossing Boundaries; and Aleksander Bursche, 'Roman Coins in Scandinavia: Some Remarks from the Continental Perspective', in John Pind et al., ed., Drik-og du vil leve skønt: Festskrift til Ulla Lund Hansen på 7o-årsdagen 18. August 2002. Publications from the National Museum, Studies in Archaeology and History 7 (Copenhagen 2002), 69-78.

34 Gombrich, Art and Illusion: A Study in the Psychology of Pictorial Representation, rev. ed. (Princeton 1961), 300; Gombrich carries his discussion further in The Preference for the Primitive, 273. 


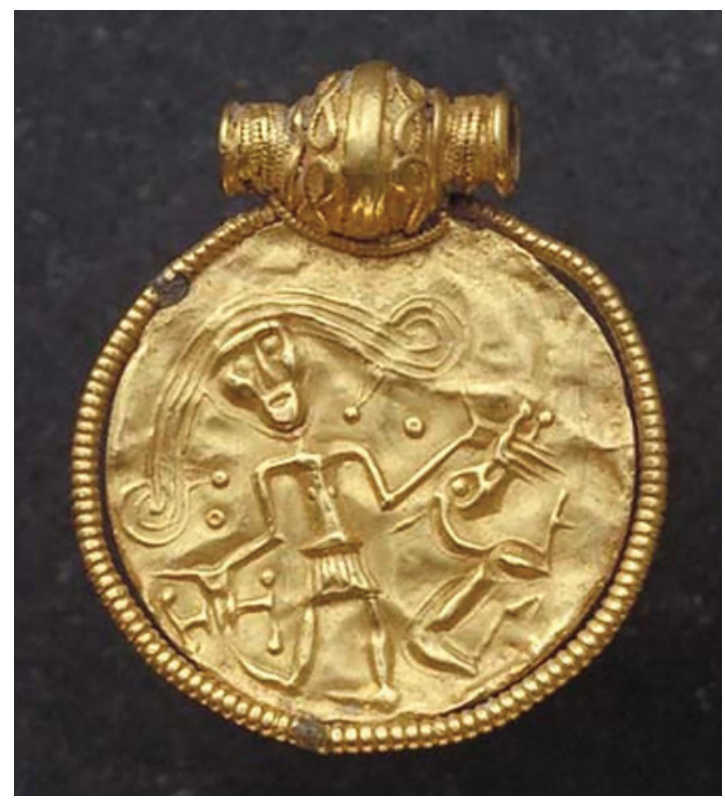

FIGURE 12.4 Full-face human head on Type B bracteate (IK 19o), from Trollhättan, Västergötland, Sweden; Statens Historiska Museet, Stockholm, inv. no. 1164; diam. $2.8 \mathrm{~cm}$ (PHOTOGRAPH NO. 14602 BY ULF BRUXE SHM 1993-07-08).

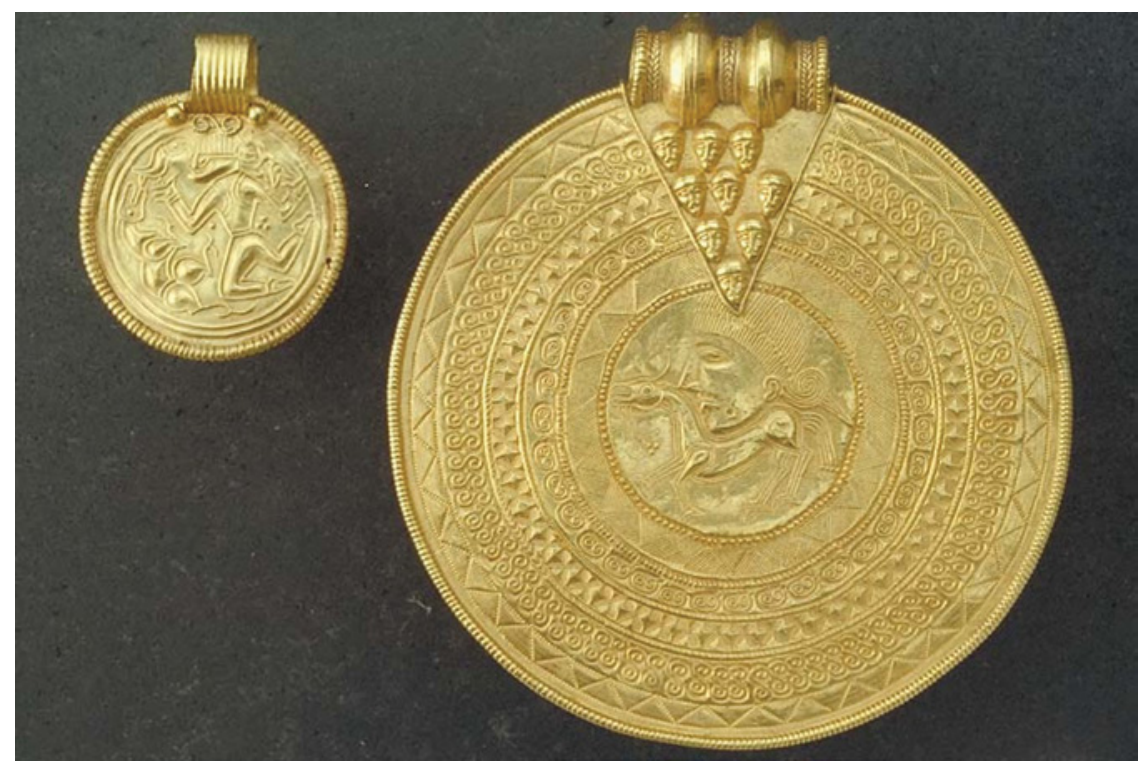

FIGURE 12.5 Profile heads on Type B bracteate (IK 143), diam. $2.86 \mathrm{~cm}$, and Type C bracteate (IK 144,1), diam. 7.32 cm, both from Ravlunda, Scania, Sweden; Statens Historiska Museet, Stockholm, inv. no. 71; (PHOTOGRAPH NO. 14058 BY ULF BRUXE SHM 1993-07-30). 
Fourth-century Roman medallions and medallion imitations exhibit the profile emperor's portrait, and over half of the approximately one thousand fifthand sixth-century bracteates - most of those known as Types A (Fig. 12.3), B (Fig. 12.5), and C (Fig. 12.5) —also display a profile human head. ${ }^{35}$

Crucial for the dating of bracteates are numerous fifth- and sixth-century solidi that are found in bracteate hoards and provide a terminus post quem. ${ }^{36}$ The later solidi show the emperor in three-quarter view rather than the profile of the earlier medallions. Consequently, it seems curious that the bracteates in these hoard finds did not follow the model of the contemporary solidi; instead they continue to harken back to the fourth-century prototypes. As an explanation for this unexpected situation, Helle Horsnæs proposes that fourth-century Roman coins 'must have been visible above ground into at least the mid-5th century', a view shared by Morten Axboe. ${ }^{37}$ If goldsmiths who produced bracteates looked directly at these early models, they must have copied and re-copied the profile view, which became further disassociated from direct observation. Peter Stewart reminds us that coin portraits referred to a prototype $^{38}$ so bracteates copy a model that was already removed from the portrait. In Gombrich's terms, the Scandinavian bracteate profile image was made through 'knowledge' of what a medallion (or bracteate) should look like rather than 'perception' of what an emperor looked like. The image was executed using the minimum elements necessary for recognition of the head as the Roman idea of a portrait was reinterpreted in a society that did not have 'the figurative habit'.39

35 Oscar Montelius first classified the Migration Period bracteates into Types A through D, groupings that still form the framework for the iconographic study of these objects; see Montelius, Från jernåldern (Stockholm 1869). The large profile head of the emperor is traceable on Types A and C, whereas a smaller profile head is seen on Type B examples that show schematic full-figures with arms and legs. Type D consists of purely animal ornamentation with no humans.

36 Morten Axboe conveniently lists these finds in an appendix to Die Goldbrakteaten der Völkerwanderungszeit-Herstellungsprobleme und Chronologie. Ergänzungsbände zum Reallexikon der Germanischen Altertumskunde 38. (Berlin 2004), 321-326.

37 Horsnæs, Crossing Boundaries, 157; and Axboe Die Goldbrakteaten der Völkerwanderungszeit, 265 .

38 Peter Stewart, 'Gell's Idols and Roman Cult', in Robin Osborne and Jeremy Tanner, eds., Art's Agency and Art History (Oxford 2007), 170.

39 I adapt the phrase 'the sculptural habit' used by Peter Stewart in, 'Geographies of Provincialism in Roman Sculpture', RIHA Journal 5 (27 July 2010), <http://www.riha-journal .org/articles/2010/stewart-geographies-of-provincialism > (accessed 11 August 2014). 
Emulating a medallion was not an easy task; in a discussion of the origin of bracteates, Haakon Shetelig remarks straightforwardly that 'coin relief is a difficult art, which is not easily improvised'. ${ }^{40}$ As the technique of the relatively thick, two-sided struck coin was abandoned in Scandinavia in favor of the thin, one-sided stamped ornament of bracteates, the style of representation was also modified. Instead of the subtle, modeled low relief of numismatic art, we now see schematic, embossed linear designs. Both technique and style change, yet the head of a man is still recognizable even though it appears in a flattened composition as if drawn with raised outlines (sometimes doubled outlines) rather than modeled in volumes. In addition, the layout constrained within a small, round field seems to have posed a dilemma in a culture that was unfamiliar with either figural or coin design. ${ }^{41}$ We may speculate about how much of the transformation from medallion to bracteate was related to the modification of techniques and how much to a desire to show Nordic subject matter rather than an alien leader, but it is too simplistic to attribute the adaptation to one or the other of these factors. Most likely, it was both. Eventually the figural image on Scandinavian bracteates no longer represented a memory of the idea of the Roman emperor; instead it may have denoted their own secular leader, a religious leader, or a Nordic deity-but we should not assume that these categories are mutually exclusive or that all bracteate images refer to the same subject. ${ }^{42}$

40 Haakon Shetelig, Classical Impulses in Scandinavian Art from the Migration Period to the Viking Age. Instituttet for sammenlignende kulturforskning, series A: Forelesninger 19 (Oslo 1949), 48.

41 I have posed this question elsewhere, see Wicker, 'The Scandinavian Animal Styles in Response to Mediterranean and Christian Narrative Art', in Martin Carver, ed., The Cross Goes North: Processes of Conversion in Northern Europe, AD 300-1300 (Woodbridge 2003), $535^{-} 536$.

The identification of the human figure is an enormous issue in bracteate studies that cannot be taken up here. Some of the major viewpoints are taken by Gunilla ÅkerströmHaugen, who traces Roman iconography on bracteates in Genesis och metamorphosis: En studie i de nordiska guldbrakteaternas ikonografi. Gothenburg Studies in Art and Architecture 31 (Gothenburg 2010); Elmar Seebold, who proposes that the figure is a secular Germanic leader in 'Römische Münzbilder und germanische Symbolwelt: Versuch einer Deutung der Bildelemente von C-Brakteaten', in Heinrich Bech, Detlev Ellmers, and Kurt Schier, eds., Germanische Religionsgeschichte: Quellen und Quellenprobleme. Ergänzungsbände zum Reallexikon der Germanischen Altertumskunde (Berlin 1992), 270-335); and Karl Hauck, who has dominated the discussion of bracteate iconography for a generation with his interpretation of the imagery on bracteates as early indication of Nordic mythology that is better known through Old Norse literature of the medieval period, in numerous works, but most recently in the summation in 'Machttaten Odins: Die 
What can we learn from medallions and bracteates about the impact of the Roman Empire in Scandinavia? The influx of medallions into the North did not stimulate the development of coinage in the Iron Age non-monetary economy; however, exposure to the figural imagery of medallions was productive and stimulated a vigorous and creative local response. Additionally, medallions were agents that served as wearable emblems to express elite status. These socially-significant artifacts were first adopted and then adapted for use in the North-renegotiated and modified, as discussed by Fraser Hunter. ${ }^{43}$ In a case-study of Roman objects found beyond the frontier in Scotland, Hunter examines material that was 'incorporated into local ways of doing things' and that then 'affected those habits'. In a similar way, medallions were consumed and incorporated into elite practice in Scandinavia and then stimulated an indigenous response-bracteates - that adapted the portraits as stylized linear designs and replaced the Roman letters with Germanic runic characters. The usage of the objects, too, was altered-from men's bestowal of military awards to women's display of family wealth and status. Yet the result was still connected at least tangentially to the larger community of the empire. In particular, the continuing use of the profile human image 'entangled' bracteates with medallions and with Roman culture. The tie to the foreign concept was unbroken, and the impact of the empire is evident as the semantic language of figural art - the very idea of representing humans in pictorial form-reached Scandinavia, far beyond the frontier.

Chiffrenwelt der Brakteaten und die Methoden ihrer Auswertung', in Wilhelm Heizmann and Morten Axboe, eds., Die Goldbrakteaten der Völkerwanderungszeit-Auswertung und Neufunde. Ergänzungsbände zum Reallexikon der Germanischen Altertumskunde 40 (Berlin 2011), 1-6o.

43 Fraser Hunter, 'The Lives of Roman Objects beyond the Frontier', in Peter S. Wells, ed., Rome beyond its Frontiers: Imports, Attitudes and Practices. Journal of Roman Archaeology Supplementary Series 94 (Portsmouth, R.I. 2013). 


\section{Index of Places}

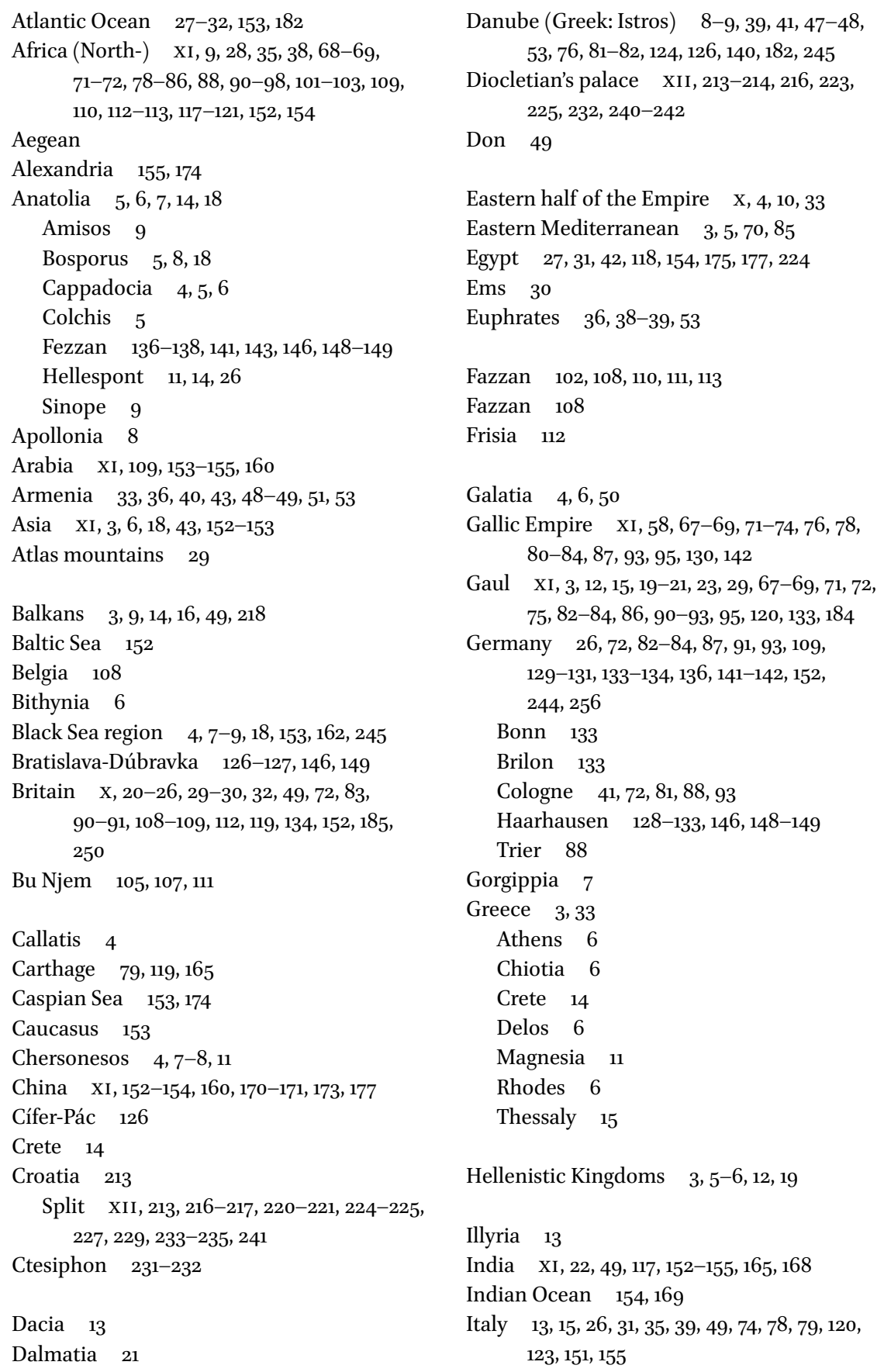


$\begin{array}{ll}\text { Jericho } & 139,149 \\ \text { Jutland } & 14,15\end{array}$

Kissi (Burkina Faso) 114, 116, 118-119

Libia $\quad 155$

Macedonia $\quad 3,8,10-13,16,18,166,224$

Mali 116

Mediterranean sea $\quad 27-29,120,15^{1-152,154}$

Mesembria 4

Mesopotamia $33-34,36,38-39,83,156$, 232, 235

Dura-Europos $\quad 36-37,40,194$

Edessa $38,41,156,234$

Moravia 128,140

Niger 116, 119

Nisibis $\quad 37-39,235$

Northern Sea $\quad 30,109,152,182$

Numidia $\quad 5,15,60,71,79,82$

Olbia 7

Ostia 121

Oxus (river) 153

Palmyra $36,58,83,94,153,193,194-201$, 206, 212

Pannonia $107,126-127,146$

Pantikapaeum 7

Paphlagonia 4

Parthia 33, 48-51, 53-55, 62, 153

Persia $\mathrm{x}, 33-39,48-50,56,60-61,63,83$, $155,213,222,224,225^{-226}, 233^{-235}$, 237-238, 240-241

Hatra $33,36-37$

Persepolis 62

Phanagoria 7

Phrygia 43
Polen 128

Pontus $\mathrm{X}, 3-4,6-9,13,18,19$

Ravenna 244

Red Sea $117,154,162$

Rhine (river) 26, 39, 41, 47-48, 53, 108-109, $112,124,133,182$

Roman Africa XI, 68, 96, 99, 102, 121

Romuliana 218-221, 223-225, 233

Sahara 102-104, 108-109, 113, 116, 119-121, $137,15^{2}$

Sardinia $\quad 3,15,118-119,134$

Scandinavia XII, 243-246, 249-251, 254-255

Denmark 245, 252

Norway 245, 249-250

Sweden 245

Scheldt 108-109

Scythia $\quad 5,49,102,153,155$

Sicily 3,15

Slovakia $125,140,143,148$

Spain $3,15,78,84,90,119,134,187$

Sri Lanka $\quad 117,154$

Sudan 115

Syria $33-34,39-40,109,153,155,157,174-175$

Antioch 39-40, 174

Damascus 154

Theodosia 7

Thracia $\quad \mathrm{X}, 3-5,8-19,43,160$

Tigris (river) 34

Tunesia 119

Tyras 7

Vietnam 154

Wadden Sea 30

Western half of the Empire $\quad \mathrm{X}, \mathrm{XI}$ 


\section{Index of Names}

\author{
Aelius Aristides 155 \\ Aemilianus 73 \\ Albinovanus Pedo $\quad 30-31$ \\ Alexander the Great $\quad 27,30,15^{2}$ \\ Ammianus Marcellinus 47, 126 \\ Andriscus 12 \\ Antoninus Pius 170, 172 \\ Appian of Alexandria 17 \\ Ardashir I 33-39, 226, 230 \\ Aristonicus 6 \\ Artabanus V of Parthia $33-34$ \\ Augustus X, 21, 23-25, 29, 51, 53, 56, 62, 89, \\ $155,160-161,165,181-182$ \\ Aurelian 46, 70, 73, 90, 92, 93 \\ Caracalla $\quad 43,57,88,89$ \\ Cassius Dio $\quad 20-21,26,33-36,107$ \\ Cicero 4, 54, 183, 185 \\ Claudius 20, 22, 26, 31 \\ Claudius II Gothicus 73 \\ Constantine the Great $\quad 53,60,168$ \\ Decius 73 \\ Dio Chrysostom $\quad 155,162$ \\ Diocletian 92, 214, 217-218, 223 \\ Gaius Caligula $\quad 26,31-32,48$ \\ Gaius Cassius 7 \\ Gaius Julius Caesar 20-22, 26, 29, 158, \\ 182-184 \\ Gaius Marius $\quad 5^{-6}$ \\ Gaius Porcius Cato 16 \\ Gaius Suetonius Tranquillus $\quad 26,32,164$ \\ Galerius 218, 222-223, 233-237, 240 \\ Gallienus $\quad 37-38,41,55-56,58,72-73,76,81$ \\ Garamantes XI, 29, 96, 102, 104-121, 136, \\ 138,141 \\ Gnaeus Manlius Vulso 11 \\ Gordian I 71, 78-80, 86, 88, 94 \\ Gordian II 79, 80 \\ Gordian III emperor $33,37-43,63,79,80$ \\ Gregory of Tours 244, 249 \\ Hannibal Barca 15 \\ Herod the Great $\quad$ 138-139, 141, 149 \\ Herodian $\quad 34-35,39$ \\ Herodotos 115, 153 \\ Hostilian 73 \\ Jugurtha $\quad 5^{-6,15}$ \\ Julian the Apostate 61 \\ Julius Obsequens $\quad 16$ \\ Justinian I 244 \\ Juvenal XII \\ Livy $3,11-12,182-183$ \\ Lucius Appuleius Saturninus 6 \\ Lucius Cornelius Sulla Felix 18 \\ Lucius Verus ( $36,53-55$ \\ Manius Aquillius 7 \\ Marcus Aurelius $\quad 54,81,170,172$ \\ Marcus Cornelius Fronto $\quad 53^{-54}$ \\ Marcus Iunianius Iustinus 17 \\ Marcus Minucius Rufus $\quad 16$ \\ Marcus Terentius Varro Lucullus 8 \\ Maximinus Thrax XI, 38, 73, 79-8o, 86, \\ 94-95 \\ Mithridates V Evergetes 14 \\ Mithridates vi Eupator $\quad 3-5,7-9,17-18$ \\ Nehalennia 109 \\ Nicomedes IV of Bithynia 7 \\ Nomads XI, 5, 16, 19, 82, 96-102, 104, 113, \\ $121-122,158$ \\ Odaenathus $\quad 37-38,41,55^{-56}, 5^{8}, 94$ \\ P. Lucinius Crassus Mucianus $\quad$ 14, 56 \\ Paerisades V 8 \\ Perseus of Macedon 11-12 \\ Petrus Patricius 44 \\ Pharnaces I $\quad 7-8$ \\ Philip the Arab $39,43,63$ \\ Pliny the Elder $\quad$ 109, 168, 182 \\ Polybius 3, 165 \\ Pompeius Magnus $\quad$ 9, 157-158 \\ Pomponius Mela 26, 28 \\ Postumus XI, 67-69, 71-78, 81-82, 84, \\ $87-88,91,93-95$
}


Publius Cornelius Tacitus 21, 30, 98, 107, 112, 131, 141, 182, 184-185

Publius Herennius Dexippus 46

Publius Vergilius Maro 57

Sallust 182

Seneca the Elder $3^{0}$

Septimius Severus $36,43,53,57,59-60,69$, $89,93,158,231$

Severus Alexander $\quad 33-35,38-42,69,71,78$

Sextus Julius Frontinus 15

Sextus Pomponius $\quad$ 167-168

Shapur I $35,38-41,44,55,62-63,155^{-156, ~} 234$

Strabo $20-21,24,29,31,154$
Theodosius II $\quad \mathrm{X}, 61,62$

Tiberius 21, 24, 48, 51-53, 56, 64, 88, 142, 244

Titus Didius 16

Trajan $\quad 53,55,57,60,154$

Valens $47,184-185$

Valentinian 249

Valerian $38,40-41,43-44,55,58,62-63$, 155,238

Vespasian 141

Xerxes $\quad 26$

Zosimus $\quad 44,72$ 


\section{General Index}

African metallurgy 110

Agriculture 24, 85, 97-98, 100-101, 111-113, 171

Amici 183

Amicitia 22, 52, 161, 163-169, 184

Auctoritas (authority) 42, 46

Augustan period $\quad 29,30,57,95,242$

bracteates XII, 244, 247-249, 250, 252, $254-256$

Ceramics XI, 83-85, 104, 120-121, 123, $126-130,132,141$

Cognomina $\quad 59^{-61}$

Coinage (also: numismatics) 9, 17, 23, 42, 44, 75-77, 80, 87-93, 123, 126-127, 161, 163,169

Early Punic Wars 27, 183

Eastern trade routes XI, 151, 153-155, 165, 169, 172

Eikones Basileioi 46

Epigraphic (evidence) 16, 45, 50, 54, 58, $75^{-} 77,80,157$

Frontiers IX-X, $5,22,44-45,47-48,52,67$, $81,83,102,108,152,182,193$

Gordians, the revolt of the (238 AD) XI

Goths 43, 47

Gundestrup Cauldron 14-15, 252

Hospitality XI

Hospites 183-184,

Hospitium XII, 180-190

Identity $\quad \mathrm{IX}-\mathrm{X}, 45,5^{6}$

Imagined community $\quad 243-244$

Imperial architecture XII, 55, 57, 143, 240-241

Imperial discourse $\quad \mathrm{x}, 26-27,29,42,45^{-46}$, $48,51,53-54,57-58,62-63,190$, $237-238,240$

Imperium Romanum $\mathrm{X}, 18,46-48,51,53,56$, $58,61,128,136,138,140-142,148-150$, $170,172,179,182$
Infrastructure $\quad 43,131-132,147,15^{-152,154}$, 171,178

Iron Age Scandinavia $\quad 252$

Late Antique Empire $\quad 45,84$

Late Bronze Age (ca. 1100-500 BC) 251

Late Hellenistic period 10

Later Roman Iron Age (ca. 50-80o AD) 243

Lex de Provinciis Praetoriis (ca. 100 BC) 16, 166

Liburnian galleys $3^{2}$

Limes 19, 103, 109-110, 125, 127, 137, 142, 146, 182

Mare nostrum $\quad 27-28,32,182-183$

Material culture XII

Medallions XII, 243-256

Medieval Period 70

Migration 14-15, 97, 100, 103

Missorium of Theodosius 244

Mithridatic wars (1st century вС) $\quad 6,17,19$

Mutinity 20, 31-32

Ostraca $\quad 105^{-107}$

Palatial architecture XII, 213-214, 216, 221, 224-232, 235, 242

Palmyrene deities XII, 193-199, 201-206, 208-211

Parthian Empire $\quad$ 19, 33-34, 36, 54, 57, 153

Pastoral economies 97, 111-113, 122

Pax Romana 48

Peregrines $\quad 181,183^{-186}$

Persian Wars (230-266 AD) 33-34, 38-39, $42-44,54$

Power of Images 57

Pre-Roman Iron Age (ca. 500 BC-50 AD) 251

Princeps (perception of) $\mathrm{X}, 21,25,45^{-46}$, $5^{1-53,58,60-63}$

Principate $\quad 11,45^{-46}, 52,55,64,155,185^{-186}$

Religion XII

Res Gestae Divi Augusti $\quad 22,23,25,29,45$, $5^{0}-52,58,63-64,182$

Res Gestae Divi Saporis ～39, 41, 45, 62, 63

Res publica 48, 61, 63 
Rhetoric $30,45,53,55$

Roma Aeterna 46

Roman diplomacy $\quad 22,160,162-166,180,235$

Roman imperialism 4, 18, 22, 25, 29, 42, 55, $69,163,238$

Romanization $\quad 23,180$

Seawalls (moles) $\quad 32$

Sedentary societies $\quad 96,98-99,101-102,121$, $15^{8}$

Seleucid Empire $\quad 36,174$

Silk Road $\quad 153,156$

Slave trade $13,115^{-116}$

Socii 183

Soldatenkaiser (Barrack emperor) 70, 73, 79,89
Tabula Peutingeriana 152, 168

Technology (use of) XI, 32, 124-125, 130, $138-139,141-148,150$

Temple of Mars the Avenger (Mars Ulptor)

49

Tetrarchy $70,214,218,221,224,230,232,235$, $238,240-241$

Thracian Wars 15

Trade XI, 9, 11, 13, 24, 36, 84, 96, 97, 100-103, 106-113, 118-123, 131, 143, 151, 153-155, 162, 165-166, 168-169

Transcontinental connectivity XI

Via Egnatia 13

Viking Age (ca. 800-1050 AD) 243, 251

Vindolanda tablets $\quad 42,107,112$ 